World Inequality Lab - Working Paper N²021/09

\title{
Democratization and the Construction of Class Cleavages in Thailand, the Philippines, Malaysia, and Indonesia, 1992-2019
}

Amory Gethin

Thanasak Jenmana

March 2021

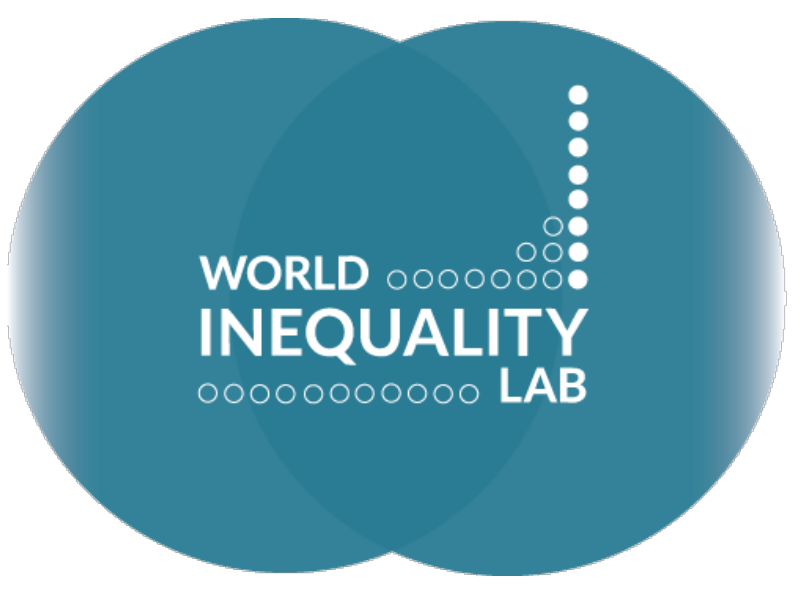

WID.WORLD

THE SOURCE FOR

GLOBAL INEQUALITY DATA 


\title{
Democratization and the Construction of Class Cleavages \\ in Thailand, the Philippines, Malaysia, and Indonesia, 1992-2019*
}

Amory Gethin

Thanasak Jenmana $^{\dagger}$

\begin{abstract}
This paper analyzes how democratization in Southeast Asia has led to the politicization of social and economic inequalities since the 1990s. Drawing on political attitudes surveys, we document how historical legacies, the structure of inequality, and institutional dynamics contributed to differentially structure political cleavages in Indonesia, Malaysia, Thailand, and the Philippines. Ethnic inequalities in Malaysia and regional inequalities in Thailand played a key role in fostering the emergence of strong class divides in these two countries. In Indonesia, by contrast, the rise of new parties mainly used as political vehicles to support their leaders has eroded pre-existing religious and socioeconomic cleavages. The Philippines' highly unstable party system led to a third trajectory, whereby class divides have been strong, but have lacked the conditions required for their institutionalization and stabilization over time.
\end{abstract}

\footnotetext{
${ }^{*}$ We are grateful to Clara Martínez-Toledano, Thomas Piketty, Dirk Tomsa, and Andreas Ufen for their useful comments.

${ }^{\dagger}$ Amory Gethin, Thanasak Jenmana: Paris School of Economics - World Inequality Lab.
} 


\section{Introduction}

What determines the emergence of class cleavages and the political representation of social inequalities in new democracies? This paper approaches this question by exploiting existing political attitudes surveys to document the determinants of voting behaviors in four recent Southeast Asian democracies: Thailand, the Philippines, Malaysia, and Indonesia. In Thailand and Indonesia, mounting opposition and economic distress in the 1990s put an end to military rule and led to the organization of freer and fairer elections. In the Philippines, the People Power Revolution of 1986 triggered the collapse of the Marcos authoritarian regime and the restoration of democracy. In Malaysia, the gradual consolidation of the opposition starting at the end of the twentieth century led to the decline of the ruling National Front coalition and eventually to the victory of the Alliance of Hope in 2018.

The emergence and stabilization of new political forces nonetheless followed very different trajectories in these four countries. In Thailand, democratization was associated with the rise of Thaksin Shinawatra's Thai Rak Thai party, strongly supported by low-income voters and especially by the poorer northern regions of the country. In Malaysia, where regular elections have been held since 1959, opposition to the dominant National Front coalition mainly came from two sides, Islamic parties and secular parties supported by ethnic minorities. The political systems of Indonesia and the Philippines, in contrast, have displayed growing instability, with

political parties increasingly serving as vehicles providing electoral resources to charismatic leaders.

These diverging dynamics resulted in significant variations in the link between socioeconomic status and the vote, and thus in the political representation of inequality. While class cleavages clearly materialized in Thailand and Malaysia, they have been more variable in the Philippines and have dwindled in Indonesia. We argue that these differences in class polarization can be better understood in light of the strength of other cleavages (in particular ethnic, religious, and regional cleavages) and of the extent to which these cleavages have interacted with socioeconomic concerns, consistently with what we observe in many other democracies, for 
instance in Pakistan (Gethin, Mehmood \& Piketty 2020), in East Asia (Durrer de la Sota \& Gethin 2021), or in Sub-Saharan Africa (Baleyte, Gethin, Govind \& Piketty 2020).

This mechanism appears to be particularly relevant to explain the trajectories of Thailand and Malaysia. In Thailand, extreme regional inequalities, among the highest observed in the world, have fostered the emergence of a center-periphery cleavage with an exceptionally pronounced class dimension, which crystallized political identities and proved to be critical to Thaksin's success. In Malaysia, it was persisting ethnic inequalities between the Chinese elites and the Bumiputra majority that partly aligned ethnic and class conflicts. Regional identities in Thailand and ethnic identities in Malaysia therefore proved to be powerful catalyzers for the emergence of what could become class-based party systems in the future, if democratization was to be achieved and political organizations were to become more institutionalized in these two countries.

Ethnoregional identities and inequalities in Indonesia and the Philippines, by contrast, have not encouraged the movement towards class-based party systems. This can partly be explained by the fact that ethnic and regional inequalities were never as strong and as binary in these two countries as they were in Malaysia and Thailand. The weakness of these cleavages can also be traced back to the history of colonial rule and independence movements, which delegitimized political parties and deliberately downplayed ethnic conflicts. While the lower classes did find a voice in the electoral arena since democratization, and social class has in practice been a significant determinant of electoral behaviors, this association has primarily been driven by specific candidates rather than by political parties. In Indonesia, the rise of opportunistic leaders has led to a remarkable dealignment of existing political cleavages. In the Philippines' exceptionally unstable party system, low-income voters have been more supportive of "propoor candidates", but this has not translated into the formation of stable party-voter linkages. Furthermore, center-periphery and class divides have represented crosscutting dimensions of political conflicts, a separation that culminated in Rodrigo Duterte's success at gathering the votes of both peripheral regions and the urban middle class. In summary, the diverging trajectories of Thai, Filipino, Malaysian, and Indonesian political cleavages lie at the 
intersection of the structure of social inequalities, the legacy of colonial and post-colonial history, and the making of democratic electoral systems.

\section{Thailand}

Among Southeast Asian countries, Thailand is unique both in the ethnic and religious homogeneity of its population - with over 95 percent of the electorate following Theravada Buddhism and speaking Thai - and in the distinctive regional structure of its inequalities. In this section, we argue that these two factors played a key role in generating a strong polarization of the electorate along class lines during the democratization era of the 2000s. These dynamics were driven by political supply, with the redistributive policies implemented by Thaksin Shinawatra leading to the mass mobilization of the poor; they trumped other dimensions of political conflict and had a strong regional component; and they led to a democratic backlash, with the middle and upper classes uniting to support military-inspired political leadership.

\section{Democratization and Inequality in Thailand}

Thailand engaged in a process of democratization at the turn of the twenty-first century. The military governments of the post-war era supported by the monarchy, with the help of exportled industrialization, US financial aid, and foreign direct investment, had been highly successful at continuously fueling economic growth since the 1960s (Satitniramai 2013). However, much of this prosperity was shared by a small proportion of the population: the majority of the working population remained employed in agriculture, while much of the fruits of development accrued to those involved in large enterprises, export industries, and the banking sector (Jenmana 2018). The 1997 Asian Financial Crisis marked a new era for Thailand. The public discontent that arose from economic shocks, along with the general dissatisfaction towards military rule that had grown since the beginning of the 1990s, fueled a growing demand for political and economic reforms. The 1997 Constitution thus introduced a number of innovations in the democratic process, strengthening the executive, allowing the upper house to be fully elected, and improving the separation between executive and legislative bodies. 
What followed was the era of Thaksin Shinawatra, the leader of the then Thai Rak Thai (TRT) party, who was elected for office in 2001 with more than 40 percent of popular votes (see Figure 12.1). At first, Thaksin mainly presented himself and the party as the ones that would restore economic growth, but the accumulation of political scandals and the elites' associated discontent led the TRT to shift to more redistributive appeals. Amongst many of the policies implemented during his mandate were the universal healthcare plan, farmers' debt rescheduling, affordable social housing, and major village microcredit schemes.

The years that followed were associated with relative political instability. A 2006 coup d'état sent Thaksin into exile. His sister Yingluck Shinawatra, running for the newly created Pheu Thai Party (PTP), nonetheless won the 2011 elections with a program promising to pursue his policies, notably increasing substantially the minimum wage. On 22 May 2014, however, Royal Army General Prayut Chan-o-cha launched another coup d'état, the twelfth in Thailand's contemporary history (Baker \& Phongpaichit 2014). The new 2017 Constitution drafted under the junta finally gave the military decisive advantages, including the appointment of the Senate and the possibility for the Prime Minister to be elected by the bicameral legislature without being one of its members. This allowed Prayut to become Prime Minister in 2019, following elections widely perceived as unfree and unfair. ${ }^{1}$

\section{Social Inequalities in Thailand and the Strength of Regional Divides}

Thailand's inequalities are not particularly well-known, yet they appear to be among the highest in the world and the highest among Southeast Asian countries (Jenmana 2018). The specificity of Thailand's inequalities lies in the extreme concentration of regional economic resources: since the 1960s, Thailand's richest provinces have always earned over 6 times the average

\footnotetext{
${ }^{1}$ Given the lack of data on these elections, the following analysis is limited to the evolution of electoral behaviors between 2001 and 2011 .
} 
income of the poorest provinces, while corresponding figures do not exceed 4 in Brazil, India, and Europe. ${ }^{2}$ This inequality is tightly linked to the division between the center and the periphery, which has been at the heart of the Thai developmental state since the end of World War II, as the policies implemented by successive military regimes disproportionately benefited Bangkok (Ouyyanont 2018).

This spatial structure of the Thai economy is represented in Figure 12.2, which shows a simple composition of income groups by region in 2011. Bangkok residents represent some 45 percent of top 10 percent income earners in Thailand, compared to nearly 0 percent of the poorest quintile of the population. Meanwhile, the Northeast region accounted for more than half of the poorest 20 percent but only 10 percent of the top decile. This is one of the strongest centerperiphery divide documented in contemporary democracies.

\section{Regionalization and the Rise of Class Cleavages}

To what extent have Thailand's extreme inequality legacy and its regional component contributed to the emergence of class divides? In 2001, consistently with Thaksin's catchall platform emphasizing economic recovery, there were no clear differences between voters in terms of income or education (Figure 12.3). Following the TRT's turn towards pro-poor policies, however, which the elites largely opposed, the term "populism" emerged for the first time in Thai politics. By 2006, it had become self-evident that there was a rising class cleavage in Thailand, which culminated in protests opposing "red-shirts" backing Thaksin to "yellowshirts" favorable to the ousting of Thaksin by the military. In 2011, even after controlling for all available sociodemographic variables except region, lower-educated and rural voters had become more likely to support the PTP by 15 and 20 percentage points respectively. This support for the TRT and then the PTP among the poor can be directly linked to the social policies implemented by the Thaksin government. The process of politicization of inequality in Thailand was therefore very comparable to the case of Brazil, where growing support for Lula

\footnotetext{
${ }^{2}$ See appendix Figures AA5 and AA6, as well as Jenmana and Gethin (2019).
} 
da Silva's Workers' Party among low-income citizens was triggered by the implementation of redistributive policies during Lula’s first mandate (Gethin \& Morgan 2021).

The difference between Thailand and Brazil, however, is that in Thailand regional and ruralurban inequalities explain almost entirely these divides. In 2011, lower-educated and lowincome voters were indeed much more likely to support the PTP than other voters, but this gap drops substantially and becomes statistically non-significant after controlling for region of residence. ${ }^{3}$ The rise of class cleavages in Thailand thus appears to have been driven by exceptional regional divides, which provided a solid foundation for the mobilization of the masses. This mobilization allowed Thaksin and Yingluck Shinawatra to achieve important electoral victories, as policies such as the minimum wage or interventions on agricultural prices played a key role in increasing the incomes of the populated poorer regions, which turned out to benefit the lower classes as a whole, in a country where center-periphery inequalities are amongst the highest in the world.

\section{The Philippines}

In comparison to Indonesia, Malaysia, and Thailand, the Philippines' party system has been exceptionally chaotic since the country's transition to democracy in 1986. In this section, we study how the interactions between ethnicity, class, and regional structures have shaped the political representation of social inequalities in the new democracy. Three main findings emerge from our analysis. First, we document that ethnic and regional specificities are only moderately linked to inequality, more than in Indonesia, but less than in Thailand, with Luzon and in particular the National Capital Region being overrepresented in top-income groups. Secondly, we show that while regional inequalities have contributed to consolidating class cleavages in Thailand, this is not the case in the Philippines, where educational and regional divides have represented crosscutting dimensions of political conflict. Thirdly, we show that the 2016 presidential election led for the first time to the complete separation of these two

\footnotetext{
${ }^{3}$ See appendix Figure A5.
} 
dimensions: support for Rodrigo Duterte in the 2016 presidential election was unique in bringing together both urban middle-class voters and poorer peripheral regions.

\section{Elections and Political Parties in the Philippines since 1986}

In no other country of Southeast Asia has democracy been experienced for such a long time as the Philippines, yet Filipino party systems never translated social cleavages into the political representation of interest groups. Instead, Filipino parties have always been opportunistic organizations building support through patron-client relationships, with the objective of securing the benefits of office and getting access to state resources (Teehankee 2013). This persisting feature of Filipino politics has its roots in the process of state-building that occurred during the twentieth century. As the US colonial administration gradually introduced elections at the beginning of the twentieth century, parties came to articulate the interests of local clans, or principalia, rather than to develop cleavages along social lines. While the rise of left-wing movements such as the peasant organization Hukbalahap (HUK) could have enabled the mobilization of counter-elites, these were altogether excluded from the democratic arena through harsh repression (Nadeau 2008). During the Third Republic (1946-1965), electoral competition hence pitted the Nacionalista Party against the Liberal Party, two virtually identical entities in terms of policy proposals and ideological affiliations.

After over twenty years of military rule under Ferdinand Marcos (1965-1986), the "People Power Revolution" of 1986 enabled the return of democracy, but the clientelistic nature of Filipino parties was left untouched. The lack of stable party loyalties among legislators, the presidential form of government, and the one-round first-past-the-post system adopted for presidential elections have since then been powerful incentives pushing individuals to constantly launch new parties and run for the presidency (Kasuya 2009).

Five presidential elections have been held in the Philippines since the People Power Revolution of 1986. In 1992, General Fidel Ramos was elected with less than 24 percent of votes against six other candidates. The 1992 election showed little variations in the determinants of support 
for candidates across social classes, and only regional and ethnolinguistic affiliations were significantly associated with candidate choices (Landé 1996). This changed in 1998, however, when movie star Joseph Estrada won the presidency with nearly 40 percent of popular votes, a large share of which came from the lower classes. The 1998 election marked a rupture in that Estrada had not used existing patronage networks as his first resource, but had rather directly appealed to the poor through a "dialectic of recognition and appropriation", promising to help the common people against the elites with his slogan "Erap [Estrada's nickname] for the poor" (Hedman 2001). However, while Thaksin Shinawatra's pro-poor campaign had been followed by concrete redistributive policies in Thailand, this was not the case of Estrada, who in fact largely continued the liberal economic agenda that his predecessors had initiated before him (Thompson 2013).

What followed was a period of political polarization, which culminated in the "Second EDSA Revolution", a mass mobilization of mostly reformist elites amidst corruption scandals, and in Estrada's resignation, replaced by Gloria Macapagal-Arroyo in 2001. In the 2004 elections, Estrada's close associate Fernando Poe ran for the presidency against Arroyo, but was defeated. Estrada ran again for president in 2010 and lost against the Liberal Party candidate Benigno Aquino.

The 2016 presidential election marked again another turning point in Filipino politics. Rodrigo Duterte, former mayor of Davao City in the island of Mindanao, was elected president with 39 percent of votes. His platform focused on the "war on drugs" and on his explicit support for the extrajudicial killings of drug users and criminals. This was key to his success among the "angry new middle class", who were afraid that growing insecurity would wipe out the benefits they had gained from recent economic growth (Thompson \& Teehankee 2016; Teehankee \& Thompson 2016). Four other candidates ran for the presidency: Mar Roxas and Miriam Defensor Santiago represented the continuity of the reformist Aquino government, while Grace Poe (the adopted daughter of Fernando Poe) and Jejomar Binay campaigned with pro-poor appeals comparable to that held by Estrada and Fernando Poe between 1998 and 2010 (Teehankee \& Thompson 2016b). 
Figure 12.5 gives a sense of these transformations by distinguishing three groups of candidates. The first group gathers candidates from traditional "reformist" or "liberal" elites running under the banners of the Lakas-CMD, the Liberal Party, or the Aksyon Party. The second group includes "pro-poor" candidates: Joseph Estrada in 1998 and 2010, Fernando Poe in 2004, and Grace Poe and Jejomar Binay in 2016. We finally treat Rodrigo Duterte separately as a third group. Again, let us stress that these classifications are highly artificial. However, they do represent distinguishable "perceptions" or "appeals" which, as we will now show, have indeed led to sharp electoral divides.

\section{Regional Inequalities in the Philippines}

The Philippines can be divided into three regions: the northern island of Luzon (about 60 percent of the electorate, of which 14 percent in the capital Manila), the southern island of Mindanao (about 20 percent), and the Visayas islands in between Luzon and Mindanao (about 20 percent). More than 170 ethnolinguistic groups, the biggest being the Visayas (about 25 percent) and the Tagalog (about 25 percent), populate these islands. ${ }^{4}$ Despite this diversity, ethnic antagonism has been relatively rare in the history of the Philippines (Arugay \& Slater 2018). The exception is Mindanao, where migration from Luzon after World War II led to repeated conflicts in Muslim areas opposing the armed forces to separatist movements.

Regional inequalities in the Philippines are significant, though not as large as in Thailand: the National Capital Region has concentrated a greater share of higher-income citizens compared to Mindanao and Visayas. ${ }^{5}$ Regional specificities and inequalities thus pave the way to the emergence of a center-periphery cleavage, but which does not have a class dimension as strong as in Thailand and could therefore represent a separate political cleavage.

\footnotetext{
${ }^{4}$ See appendix Table BA2.

${ }^{5}$ See appendix Figures BA9 and BA10.
} 


\section{The Persistence of Class Polarization}

As we discussed above, Filipino politics since 1998 have seen the emergence of "pro-poor" presidential candidates emphasizing their proximity with the masses, albeit in a more rhetorical rather than programmatic way. Figure 12.6 shows that grouping Joseph Estrada, Fernando Poe, Grace Poe, and Jejomar Binay together reveals the persistence of remarkably strong cleavages: university graduates have been less likely to vote for pro-poor candidates by between 10 and 22 percentage points. This gap only marginally decreases after controls.

Such divisions are large in comparative perspective, and as large as what we observed in Thailand. Class cleavages therefore do not seem to have been a purely temporary feature of Filipino politics. The main difference between the Philippines and Thailand, however, is that this dimension has manifested itself in "moral" appeals rather than in competing economic programs or grassroots organizations (Thompson 2013).

Have class cleavages been reinforced by, or coupled with, center-periphery cleavages? Figure 12.7 shows that support for pro-poor candidates has generally been lower in Visayas than in Mindanao and Luzon, so that they have attracted voters from both the poorer periphery (Mindanao) and the center (the National Capital Region). The 2016 elections, however, signaled a change in this pattern: Grace Poe and Jejomar Binay made better scores in Luzon than in Visayas and Mindanao. This, as we will show below, is due to Rodrigo Duterte's success at capturing votes in the periphery. Regional differences therefore seem to have represented a clearly independent dimension of electoral behaviors in the Philippines, unlike in Thailand.

\section{The Structure of Political Cleavages in the 2016 Presidential Election}

Table 12.1 provides a detailed description of the structure of the vote for each candidate in the 2016 presidential election. Two key results are visible. First, while class polarization appeared to be lower than in 2004, it was still significant in the case of Grace Poe and Jejomar Binay, 
who made better scores among lower-educated voters. Secondly, center-periphery divides were more clearly materialized in the 2016 election than before, but went in a direction opposite to that of class cleavages. Poe and Binay were the candidates of the poor, but they were also the candidates of the center. Duterte was on the contrary the candidate of the urban middle class, but also of the periphery and of the Muslim minority, with over 60 percent of voters from Mindanao supporting him.

These two facts largely explain why Duterte's voting base was so socially diverse. On the one hand, the candidate's radical proposal of a "war on drugs" was successful among the new, younger educated middle class who valued his emphasis on law and order. On the other hand, Duterte's stronghold in Mindanao enabled him to gain votes from poorer regions, a support that he reinforced with his proposal of moving towards a federal form of government (Teehankee 2018).

\section{Malaysia}

Post-colonial Malaysia, inheriting a large and ethnically diverse territory, established itself as a federal constitutional monarchy in 1963. A one-party dominant system soon emerged, as the National Front coalition (Barisan Nasional, BN) succeeded in amalgamating the interests of the majority of Malay, Chinese, and Indian elites. The Asian Financial Crisis in 1997 shook the foundations of this regime and initiated a period of consolidation of the opposition, which culminated in the victory of the Alliance of Hope and in the first handover in the country's history in 2018. In this section, we show that the decline of the BN has been associated with growing ethnic and class cleavages, as not only Chinese voters but also top-income and highesteducated voters from other ethnic groups have gradually shifted towards the opposition.

\section{Democratization and the Erosion of the One-Party Dominant System}

After over a century of British rule, Malaysia became an independent nation in 1957. The new country brought together heterogeneous populations. The Bumiputras, divided into Muslim 
Malays and indigenous peoples, represented and still represent the majority of the population (about 70 percent in 2020) (Department of Statistics Malaysia 2020). They coexisted with significant Chinese and Indian minorities (about 23 and 7 percent in 2020 respectively), most of which descended from workers brought by the colonial power throughout the nineteenth century. Unlike other major independence movements such as in Senegal, Botswana or India, Malaysia's political movements soon took a strong ethnic dimension. While the Young Malays Union, founded in 1938 in Kuala Lumpur, advocated for the union of British Malaya and the Dutch East Indies regardless of ethnic origin, it never managed to reach mass support. Similarly, the Malayan Communist Party called for an independent state with equality for all the races, but it remained a primarily Chinese organization until it was eventually crushed by the British during the Malayan Emergency (1948-1960).

The 1955 elections (see Figure 12.8), held under colonial rule, resulted in the landslide victory of the Alliance Party (which would become the National Front in 1973), a unique coalition between three parties representing the major ethnic groups: the United Malays National Organisation (UMNO, 59 percent of votes), the Malayan Chinese Association (MCA, 20 percent), and the Malayan Indian Congress (MIC, 3 percent). Malaysia's model of consociationalism was born: while political representation would remain shaped by ethnic identities, conflicts would be limited by the cooperation between the elites of the different groups. At the heart of this association lied a fragile agreement: the Malay majority would be given political supremacy, while protection of economic property, religion, and civil rights would be granted to Chinese and Indian communities.

Until the late twentieth century, the BN remained unchallenged by its two irreconcilable opponents, the Malaysian Islamic Party (Parti Islam Se-Malaysia, PAS) advocating for an Islamic state and Malay supremacy, and the Democratic Action Party (DAP) promoting the establishment of a secular, multi-racial democracy. As in many other one-dominant party systems, electoral malapportionment in favor of rural areas, patronage networks, and other incumbency advantages hugely benefited the ruling party in a system often referred to as a “competitive authoritarianism" (Croissant 2018; Weiss 2015). 
The Asian Financial Crisis yet triggered the rise of opposition movements in a context of internal struggles within UMNO (Freedman 2006). As divisions between Prime Minister Mahathir bin Mohamad and Deputy Prime Minister Anwar Ibrahim grew over economic policy in 1998, in particular, Anwar was fired, expelled from UMNO, and arrested on charges of corruption and sodomy perceived by many as illegitimate. This triggered the emergence of the reformasi movement calling for democratic reforms, and to the formation of the National Justice Party in 1999, which became the People's Justice Party (Parti Keadilan Rakyat, PKR) in 2003 and gathered over 20 percent of popular votes at its peak in 2013. After several alliances failed to coalesce sufficient support to defeat the incumbent, the 2018 elections finally enabled the first handover in the country's history: the progressive and reformist Alliance of Hope (Pakatan Harapan, PH), bringing together the PKR, the DAP, and two other small parties, received 46 percent of popular votes against 34 percent for the BN. This victory was possible thanks to the consolidation of a more coherent and comprehensive coalition emphasizing political reforms, anti-corruption measures, and enhanced liberties, as well as unprecedented mobilization through online social media (Ufen 2020).

\section{Ethnic Inequalities in Malaysia}

At the time of independence, colonial legacy had left high inequalities with an important ethnic component: the Bumiputera majority were substantially poorer than the Chinese, who held the lion's share of wealth thanks to their overrepresentation in the industry and in the banking and insurance sectors (Ravallion 2019). Malaysia's socioeconomic structure was therefore very comparable to that of Taiwan and South Africa at the same period, two other countries where ethnic minorities have historically dominated the control of economic resources (Durrer de la Sota \& Gethin 2021; Gethin 2020). As ethnic riots broke in 1969 in Kuala Lumpur, the government was prompted to put these inequalities at the center of its policy agenda. This led to the implementation of the New Economic Policy (NEP) in 1971 and to the multiplication of positive discrimination policies in the decades that followed, which enabled the Bumiputera to 
be favored in many dimensions such as access to education, public sector employment, housing, and corporate share ownership.

In part as the result of these measures, ethnic inequalities have declined, even though they have remained significant until today. In 2014, the Chinese represented 16 percent of the poorest half of the population but 60 percent of the top 1 percent (Khalid \& Yang 2019). Ethnic income gaps in Malaysia therefore appear to be lower than in South Africa, but higher than in Taiwan, where the mainlander-native income gap has today almost completely disappeared.

\section{Ethnic Divides and Cross-Ethnic Class Cleavages}

How has the push for democratization, the subsequent decline of the $\mathrm{BN}$, and the dynamics of inequality affected political cleavages in Malaysia? As shown in Figure 12.9, ethnic divides have risen in the past two decades: while variables on ethnic identities are unfortunately not available in the surveys used in this paper, Buddhists and Taoists (most of which are Chinese) have become much less supportive of the BN than Muslims (most of which are Bumiputera). This is a well-known fact, which led BN politicians and state-controlled media to speak of an electoral "Chinese Tsunami" and to accuse the Chinese of being ungrateful after the publication of election results in 2013 (Ufen 2020). Survey data on the most recent election was not available at the time of writing, but this dynamic seems to have continued in 2018: according to existing polls, an estimated 95 percent of Chinese voted for the $\mathrm{PH}$, compared to about twothirds of Indians and a third of Malays (The New Paper 2018).

The erosion of Malaysia's one-party system, or rather of its "one-coalition system", has therefore led to the rise of ethnic voting. However, support for the BN has declined among all ethnic groups, not only among the Chinese minority, and the $\mathrm{BN}$ remains a multi-ethnic coalition. Strikingly, socioeconomic differentiation within ethnic groups appeared to be a major and rising factor distinguishing the BN from the opposition: in 2013, top-income voters were more likely to vote against the BN by 17 percentage points, a gap that remains significant after controlling for religion and other factors (Figure 12.10). This suggests that class has become 
increasingly relevant for understanding voting behaviors in Malaysia. Furthermore, at least until 2013, the BN appeared to be relatively more supported not only by poorer Muslims, but also by poorer voters belonging to other ethnic groups: in the 2013 elections, 35 percent of the poorest half of non-Muslims supported the BN, compared to 7 percent of the top decile (Figure 12.11).

The $\mathrm{BN}$ has thus remained much more popular among the poor, together with rural areas and older voters, arguably thanks to patronage networks and lower access to political information among these social groups, but also thanks to its remarkable achievements in reducing poverty in the second half of the twentieth century. ${ }^{6}$ Indeed, according to existing evidence, economic development in recent years seems to have benefited not only the Bumiputeras, but also lowincome Chinese and Indians, who have enjoyed significant above-average income growth. ${ }^{7}$ On the contrary, urban, highest-educated elites have had greater access to political information and have been more concerned about corruption, democratization, and civil liberties, topics that the growing opposition has sought to embody.

Together, these results suggest that two parallel dynamics may shape Malaysian politics in the future. On the one hand, UMNO's history of favoring Malay interests, as well as uncertain political outcomes, may convince non-Malay voters to continue increasingly supporting opposition parties. On the other hand, the BN could succeed in reinventing itself to get back some votes from minorities and become the coalition of the most disadvantaged citizens regardless of ethnicity.

\section{Indonesia}

\footnotetext{
${ }^{6}$ See appendix Figures CB5, CB6, CC6, and CC7.

${ }^{7}$ See Khalid \& Yang (2019), Figure 4.19.
} 
After three decades of authoritarian rule, Indonesia held in 1999 its first free election since 1955. In this section, we show that political cleavages in the world's largest Muslim-majority country have followed a very different trajectory from that of Thailand, the Philippines, and Malaysia: instead of undergoing a process of polarization, Indonesia's party system seems on the contrary to have been characterized by increasing dealignment. As a result, while religion, income, and other factors do continue to play a role, the rise of catchall parties has weakened the political representation of social inequalities in the new democracy.

\section{The Making of Indonesian Democracy}

After four years of resistance against the Dutch, who had sought to get back their colony from the Japanese at the end of World War II, Indonesia was recognized as an independent nation by the Netherlands in 1949. At that time, unlike in Malaysia, the political movements that had flourished in the archipelago since the beginning of the twentieth century were not communal. The key point of tension was, instead, between Islam and Marxism. On the one hand were the Masyumi Party and the Nahdlatul Ulama, which respectively represented modernist and traditionalist Islamic movements. On the other hand was the Indonesian Communist Party (Partai Komunis Indonesia, PKI) promoting a strongly secular vision of the new nation. In between, the Indonesian National Party (Partai Nasional Indonesia, PNI), associated to founding father Sukarno, emphasized secular-nationalism and state centralism. Each of these parties received between 16 and 22 percent of votes in the legislative elections of 1955 (Brown 2003).

As tensions and political instability grew, Indonesian democracy soon deteriorated, until President Sukarno proclaimed the transition to a "Guided Democracy" in 1957, in which the key poles of the nation - the military, communists, and some Muslim movements - would be allowed to participate in a cooperative government. A coup attempt, followed by a countercoup organized by General Suharto, nonetheless led to the dissolution of the regime in 1965 1966. The PKI was blamed for having organized the coup, and the massive anti-communist purge that followed left between 500,000 and 1 million dead, effectively annihilating the left- 
wing pole of Indonesian politics. These series of events, together with Sukarno and Suharto's general delegitimization of political parties depicted as divisive and corrupted, had long-lasting effects on Indonesian democracy and on the personalization of political power (Tan 2014).

Under Suharto's New Order (1965-1998), Islamic movements were forced to unite in the United Development Party (Partai Persatuan Pembangunan, PPP), while nationalist and Christian parties were compelled to gather in the Indonesian Democratic Party (Partai Demokrasi Indonesia, PDI). Meanwhile, the Party of Functional Groups (Partai Golongan Karya, Golkar) was set up as the government's electoral vehicle, and gathered a majority of votes in elections mainly used to back the authoritarian regime. While divisions were downplayed and efforts made to depoliticize the population, opposition to the regime was stronger in Java and urban areas. Golkar, on the contrary, was most supported in the peripheral regions of the country and in rural areas, a cleavage that would perpetuate to the present day (Ufen 2013).

After decades of exceptional economic development, the Asian Financial Crisis put a sudden end to the regime, and Suharto stepped down in 1998. The post-Suharto era came with the reestablishment of democracy and the organization of legislative elections in 1999. Strikingly, with the exception of the communist element, the emerging party system seemed to reproduce many of the cleavages that had characterized the 1955 election (King 2003). The secularnationalist and pro-poor Indonesian Democratic Party - Struggle (Partai Demokrasi Indonesia Perjuangan, PDI-P), led by Sukarno's daughter Megawati Sukarnoputri, arrived first with 34 percent of votes, followed by Golkar with 22 percent (Figure 12.12). A variety of Islam-based parties came next, together gathering about a third of popular votes, the most important being the traditionalist National Awakening Party (Partai Kebangkitan Bangsa, PKB), the PPP, and the modernist National Mandate Party (Partai Amanat Nasional, PAN).

This party system was soon to be upset by growing personalization and instability. In 2001, the catchall Democratic Party (Partai Demokrat, PD) was formed to support former general Susilo Bambang Yudhoyono. Yudhoyono won the 2004 and 2009 presidential elections, and the PD arrived first in the 2009 legislative elections with 21 percent of votes, but its success was short- 
lived, and only 8 percent of voters supported the PD in the 2019 legislative elections. Similarly, the Great Indonesia Movement Party (Partai Gerakan Indonesia Raya, Gerindra) has mainly served as the political platform of former general Prabowo Subianto, who lost against PDI-P candidate Joko Widodo in the 2014 and 2019 presidential races. Other new parties have also included the Nasdem Party and Hanura, both splits from Golkar. As shown in Figure 12.12, the scores achieved by the PDI-P and especially by Golkar, Indonesia's most institutionalized party (Tomsa 2008), have never reached back their 1999 peak as these new political forces emerged.

The Indonesian party system has therefore been characterized by extraordinary fragmentation in recent years, with no party securing more than 20 percent of votes in 2014 and 2019. Rather than reflecting a complexification of social divides, this process seems to have been driven by opportunistic actors and "presidentialized parties" often avoiding ideology and aiming to transcend cleavages (Ufen 2008). While historical divides materialized in the 1955 election do still seem to play a role, manifested by the persistence of traditional parties, they have become increasingly blurred.

\section{Political Cleavages and Socioeconomic Divides}

To what extent has the Indonesian party system represented socioeconomic inequalities since democratization? In comparison to Malaysia, the major pre-independence political movements were not restricted to specific ethnic groups in Indonesia, and ethnic inequalities and ethnic conflicts have remained limited in comparative perspective (Aspinall 2011). Ethnicity has accordingly never been a strong determinant of the vote: the PDI-P has been more popular in Java and Golkar in peripheral regions, but all parties have relied on large cross-ethnic and crossregional coalitions since $1999 .{ }^{8}$ This lack of cleavage has been reinforced by the electoral system, as only parties with sufficient national scope have been allowed to participate in

\footnotetext{
${ }^{8}$ See appendix Figures DB11, DC11, and DH11, and Mujani, Liddle \& Ambardi (2018), chapter 4. The exception is the PKB, whose base of support has been almost exclusively located in Java.
} 
elections (Ufen 2008b). Thus, since 2011, only parties present in all provinces, in 75 percent of the municipalities of each of these provinces, and in 50 percent of the subdistricts of each of these municipalities have been allowed to contest national elections (International Foundation for Electoral Systems 2019). As a result of these various factors, regional or ethnic identities have not been major drivers of electoral and socioeconomic differentiation in contemporary Indonesia, in contrast to the Thai and Malaysian cases.

Religion has proved to be a much stronger determinant of partisan affiliations. As shown in Figures 12.13 and 12.14, Muslims participating "often" or "always" to collective prayers have been much more likely to support Islamic parties, while the PDI-P and Nasdem have been more popular among non-practicing Muslims and especially among religious minorities (mostly Christians and Hindus, about 10 percent of the electorate since 1999 $)$. Golkar, Gerindra, and Hanura have lied in between, with vote shares varying little across religious groups, consistently with Golkar's historical ability to amalgamate elites from various streams. ${ }^{10}$ Pluralism, secularism, and attitudes towards minorities therefore appear to have represented an important dimension of Indonesian politics, a divide that has also been visible in party members' diverging attitudes towards these issues (Fossati \& Warburton 2018).

This cleavage, however, lost much of its electoral significance between 1999 and 2014, especially between practicing and non-practicing Muslims, who only differed marginally in their voting behaviors in 2014. This is consistent with the fact that conflicts between Indonesian parties on religious matters have weakened, as historically secular parties have had to govern in large coalitions, often with Islamic parties (Ufen 2013). As in the case of ethnicity, furthermore, the religious-secular cleavage has only had a weak socioeconomic component in contrast to the Malaysian case, as overall inequalities between Muslims and non-Muslims are

\footnotetext{
${ }^{9}$ See appendix Table AD2.

${ }^{10}$ We group Nasdem with PDI-P here given the more secular and pro-poor orientation of Nasdem, but all our results are strongly robust to considering PDI-P alone: see appendix Figures DI1 to DI12.
} 
low in Indonesia. ${ }^{11}$ That being said, while this evolution holds when looking at the country as a whole, ethnoreligious divides did play a greater and rising influence on local politics in recent years. The 2016-2017 Islamic mobilization against the Chinese and Christian Governor of Jakarta Basuki Tjahaja Purnama, for instance, who was accused by the protestors of committing blasphemy, incorporated not only religious, but also socioeconomic grievances directed against the non-Muslim Jakartan elite (Mietzner, Muhtadi \& Halida 2018; Warburton \& Gammon 2017).

Finally, we find that PDI-P and Golkar used to be relatively more popular among low-income voters, while Islamic parties made better scores among top-income voters in 1999 (Figure 12.15). This is consistent with the fact that the PDI-P has sought to embody Sukarno's secularnationalist legacy, while Islamic parties and in particular the PAN have historically fared better among educated voters in urban areas (Mujani, Liddle \& Ambardi 2018). This cleavage however appears to have disappeared or even reverted in recent years.

In summary, Indonesian political cleavages seem to have gradually declined since 1999 as the result of a combination of factors including personalization, party system fragmentation, and the rise of swing voters (Ufen 2013). While this could be positive to lower political polarization, it could also contribute to further delegitimizing democracy and especially political parties, already very unpopular in Indonesia (Yani 2015). Whether the trend towards monopolization of political resources in the hands of charismatic individuals will continue, or whether new class-based parties and political coalitions could eventually counteract these tendencies remains an open question.

\footnotetext{
${ }^{11}$ See appendix Figure DA8.
} 


\section{References}

E. Aspinall, "Democratization and Ethnic Politics in Indonesia: Nine Theses," Journal of East Asian Studies 11, no. 2 (2011): 289-319.

A. A. Arugay and D. Slater, "Polarization Without Poles: Machiavellian Conflicts and the Philippines' Lost Decade of Democracy, 2000-2010," Annals of the American Academy of Political and Social Science 681, no. 1 (2018): 122-136.

C. J. Baker and P. Phongpaichit, A History of Thailand (Cambridge University Press, 2014).

J. Baleyte, A. Gethin, Y. Govind, and T. Piketty, "Social Inequalities and the Politicization of Ethnic Cleavages in Botswana, Ghana, Nigeria, and Senegal, 1999-2019” (WID.world Working Paper, 2020).

C. Brown, A Short History of Indonesia (Allen \& Unwin, 2003).

A. Croissant, "Malaysia: Competitive Authoritarianism in a Plural Society," in Comparative Politics of Southeast Asia, ed. A. Croissant and P. Lorenz (Springer International, 2018): 141176

Department of Statistics Malaysia, "Current Population Estimates, Malaysia, 2020", www.dosm.gov.my, July 152020 (accessed September 8 2020).

C. Durrer de la Sota and A. Gethin, "Inequality, Identity, and the Structure of Political Cleavages in South Korea, Taiwan, and Hong Kong, 1996-2016” (WID.world Working Paper, 2020).

D. Fossati and E. Warburton, “Indonesia's Political Parties and Minorities” (ISEAS Institute, 2018).

A. L. Freedman, Political Change and Consolidation : Democracy's Rocky Road in Thailand, Indonesia, South Korea, and Malaysia (Palgrave Macmillan, 2006).

A. Gethin, "Extreme Inequality and the Structure of Political Cleavages in South Africa, 19942019” (WID.world Working Paper, 2020). 
A. Gethin, S. Mehmood, and T. Piketty, "Social Inequality and the Dynamics of Political and Ethnolinguistic Divides in Pakistan, 1970-2018” (WID.world Working Paper, 2020).

A. Gethin and M. Morgan, "Democracy and the Politicization of Inequality in Brazil, 19892018” (WID.world Working Paper, 2021).

E. E. Hedman, "The Spectre of Populism in Philippine Politics and Society: Artista, Masa, Eraption!," South East Asia Research 9, no. 1 (2001): 5-44.

International Foundation for Electoral Systems, "Elections in Indonesia: 2019 Concurrent Presidential and Legislative Elections" (2019).

T. Jenmana, "Democratisation and the Emergence of Class Conflicts. Income Inequality in Thailand, 2001-2016" (WID.world Working Paper, 2018).

T. Jenmana and A. Gethin, "Extreme Inequality, Democratisation and Class Struggles in Thailand" (WID.world Issue Brief, 2019).

Y. Kasuya, Presidential Bandwagons: Parties and Party Systems in the Philippines (Anvil Publishing, 2009).

M. Khalid and L. Yang, "Income Inequality and Ethnic Cleavages in Malaysia: Evidence from Distributional National Accounts (1984-2014)” (WID.world Working Paper, 2019).

D. King, Half-Hearted Reform: Electoral Institutions and the Struggle for Democracy in Indonesia (Praeger, 2003).

C. H. Landé, Post-Marcos Politics: A Geographical and Statistical Analysis of the 1992 Presidential Election (Institute of Southeast Asian Studies, 1996).

M. Mietzner, B. Muhtadi, and R. Halida, "Entrepreneurs of Grievance: Drivers and Effects of Indonesia's Islamist Mobilization," Bijdragen tot de taal-, land-en volkenkunde / Journal of the Humanities and Social Sciences of Southeast Asia 174, no. 2-3 (2018): 159-187.

S. Mujani, R. W. Liddle, and K. Ambardi, Voting Behavior in Indonesia since Democratization: Critical Democrats (Cambridge University Press, 2018).

K. Nadeau, The History of the Philippines (Greenwood, 2008). 
P. Ouyyanont, A Regional Economic History of Thailand (ISEAS-Yusof Ishak Institute, 2018).

M. Ravallion, "Ethnic Inequality and Poverty in Malaysia since 1969” (NBER Working Paper, 2019).

A. Satitniramai, The Rise and Fall of the Bankers' Capitalism: 60 Years of the Thai Political Economy (SameSkybooks, 2013) [in thai].

P. J. Tan, "Explaining Party System Institutionalization in Indonesia," in Party System Institutionalization in Asia: Democracies, Autocracies, and the Shadows of the Past, ed. A. Hicken and E. Kuhonta (Cambridge University Press, 2014): 236-259.

J. C. Teehankee, "Clientelism and Party Politics in the Philippines," in Party Politics in Southeast Asia, ed. D. Tomsa and A. Ufen (Routledge, 2013).

J. C. Teehankee, "Regional Dimensions of the 2016 General Elections in the Philippines: Emerging Contours of Federalism,” Regional and Federal Studies 28, no. 3 (2018): 383-394.

J. C. Teehankee and M. R. Thompson, "Duterte and the Politics of Anger in the Philippines," East Asia Forum, May 8, 2016.

J. C. Teehankee and M. R. Thompson, "The Vote in the Philippines: Electing a Strongman," Journal of Democracy 27, no. 4 (2016): 125-134.

The New Paper, "Malaysia election: 3-way split in Malay vote, most Chinese voted PH", The New Paper, https://www.tnp.sg/news/world/malaysia-election-3-way-split-malay-vote-mostchinese-voted-ph, June 142018 (accessed September 7 2020).

M. R. Thompson, "Class, Charisma, and Clientelism in Thai and Philippines Populist Parties," in Party Politics in Southeast Asia, ed. D. Tomsa and A. Ufen (Routledge, 2013).

M. R. Thompson and J. C. Teehankee, "Duterte Victory: A Repudiation of Aquino", Nikkei Asian Review, May 12, 2016.

D. Tomsa, Party Politics and Democratization in Indonesia: Golkar in the Post-Suharto Era (Routledge, 2008). 
A. Ufen, "The Evolution of Cleavages in the Indonesian Party System" (GIGA Working Paper 74, 2008).

A. Ufen, "From Aliran to Dealignment: Political Parties in Post-Suharto Indonesia," South East Asia Research 16, no. 1 (2008): 5-41.

A. Ufen, "Lipset and Rokkan in Southeast Asia: Indonesia in comparative perspective," in Party Politics in Southeast Asia: Clientelism and Electoral Competition in Indonesia, Thailand and the Philippines, ed. D. Tomsa and A. Ufen (Routledge, 2013): 40-61.

A. Ufen, "Opposition in Transition: Pre-Electoral Coalitions and the 2018 Electoral Breakthrough in Malaysia," Democratization 27, no. 2 (2020): 167-184.

E. Warbuton and L. Gammon, "Class Dismissed? Economic Fairness and Identity Politics in Indonesia," New Mandala, 5 May 2017, https://www.newmandala.org/economic-injusticeidentity-politics-indonesia/ (accessed 10 October 2020).

M. L. Weiss, "The Antidemocratic Potential of Party System Institutionalization: Malaysia as Morality Tale?," in Party System Institutionalization in Asia: Democracies, Autocracies, and the Shadows of the Past, ed. A. Hicken and E. M. Kuhonta (Cambridge University Press, 2015): $25-48$.

A. A. Yani, "The Dynamic of Indonesian Political Trust in the Beginning of Reform Era", Politik 12, no. 1 (2015): 55-68. 
Figure 1 - Election results in Thailand, 2001-2019

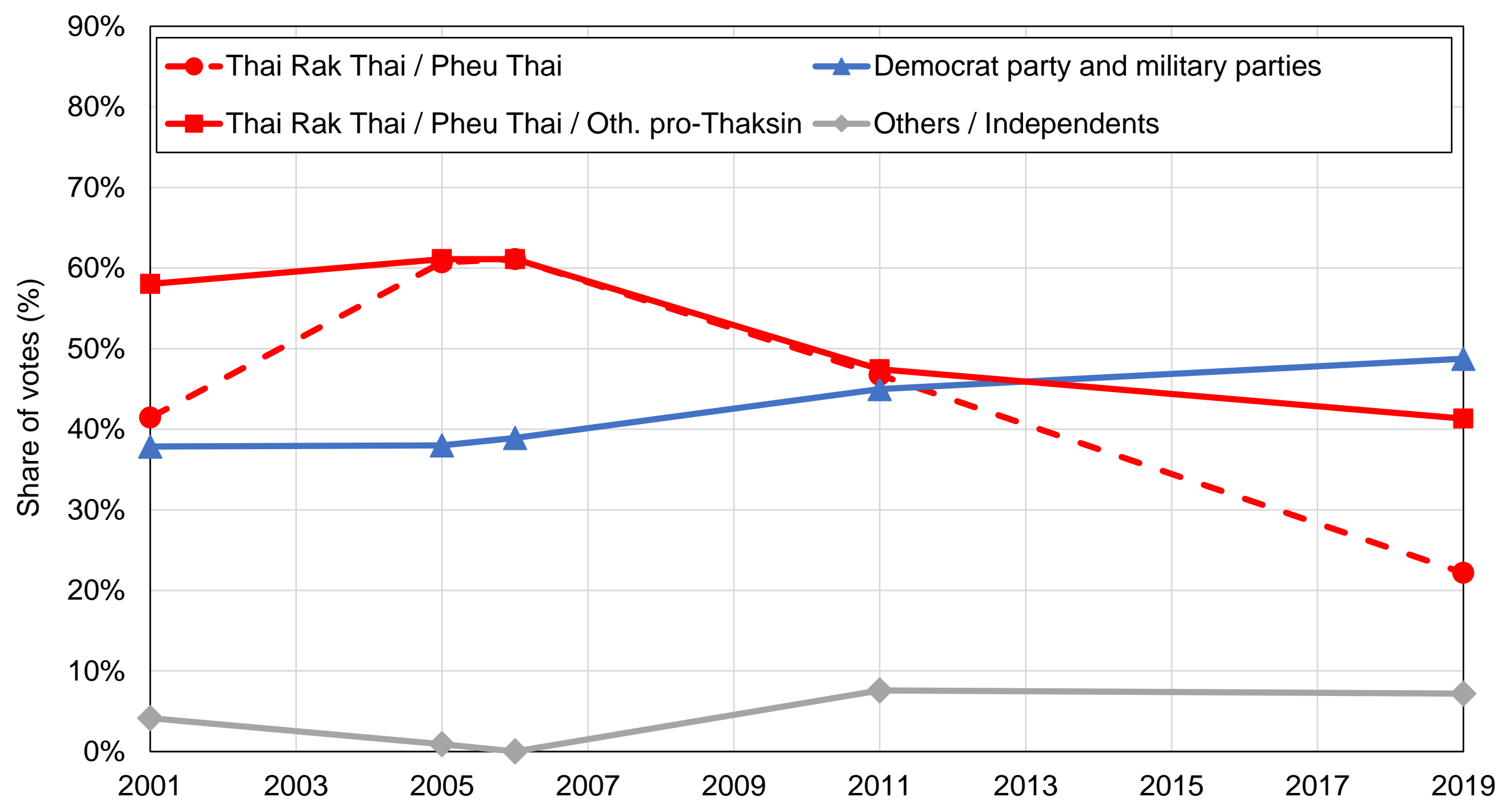

Source: authors' computations using official election results (see wpid.world).

Note: the figure shows the share of votes received by selected political parties or groups of parties in general elections held in Thailand between 2001 and 2019. 
Figure 2 - Regional inequalities in Thailand

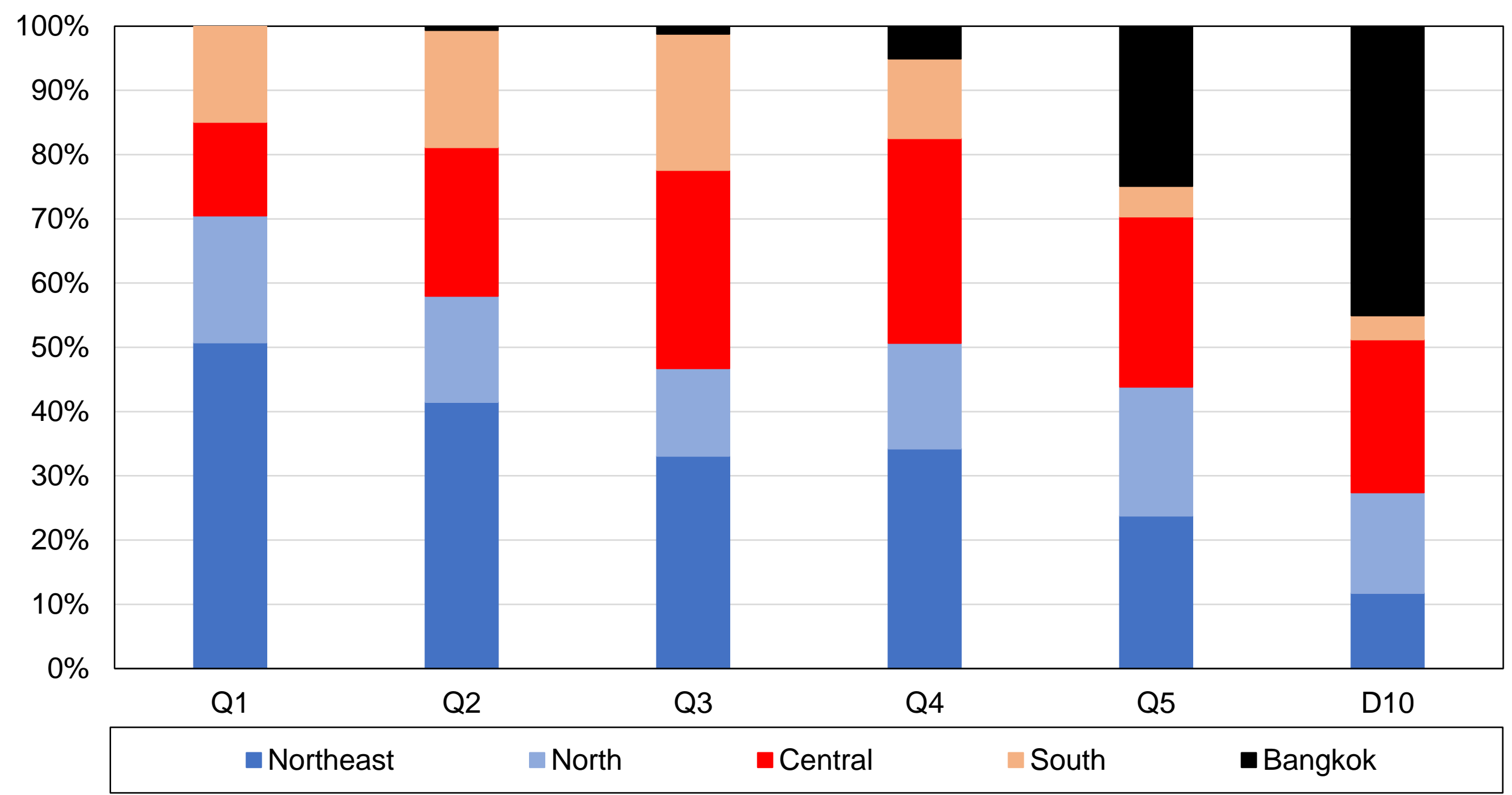

Source: authors' computations using Thai political attitudes surveys (see wpid.world).

Note: the figure shows the composition of income groups (quintiles (Q1 to Q5) and the top decile (D10)) by region in 2011. In $2011,45 \%$ of top $10 \%$ income earners lived in Bangkok, compared to only $12 \%$ in the Northeast. This region concentrated alone more than half of bottom $20 \%$ income earners. 


\section{Figure 3 - The educational cleavage in Thailand, 2001-2011}

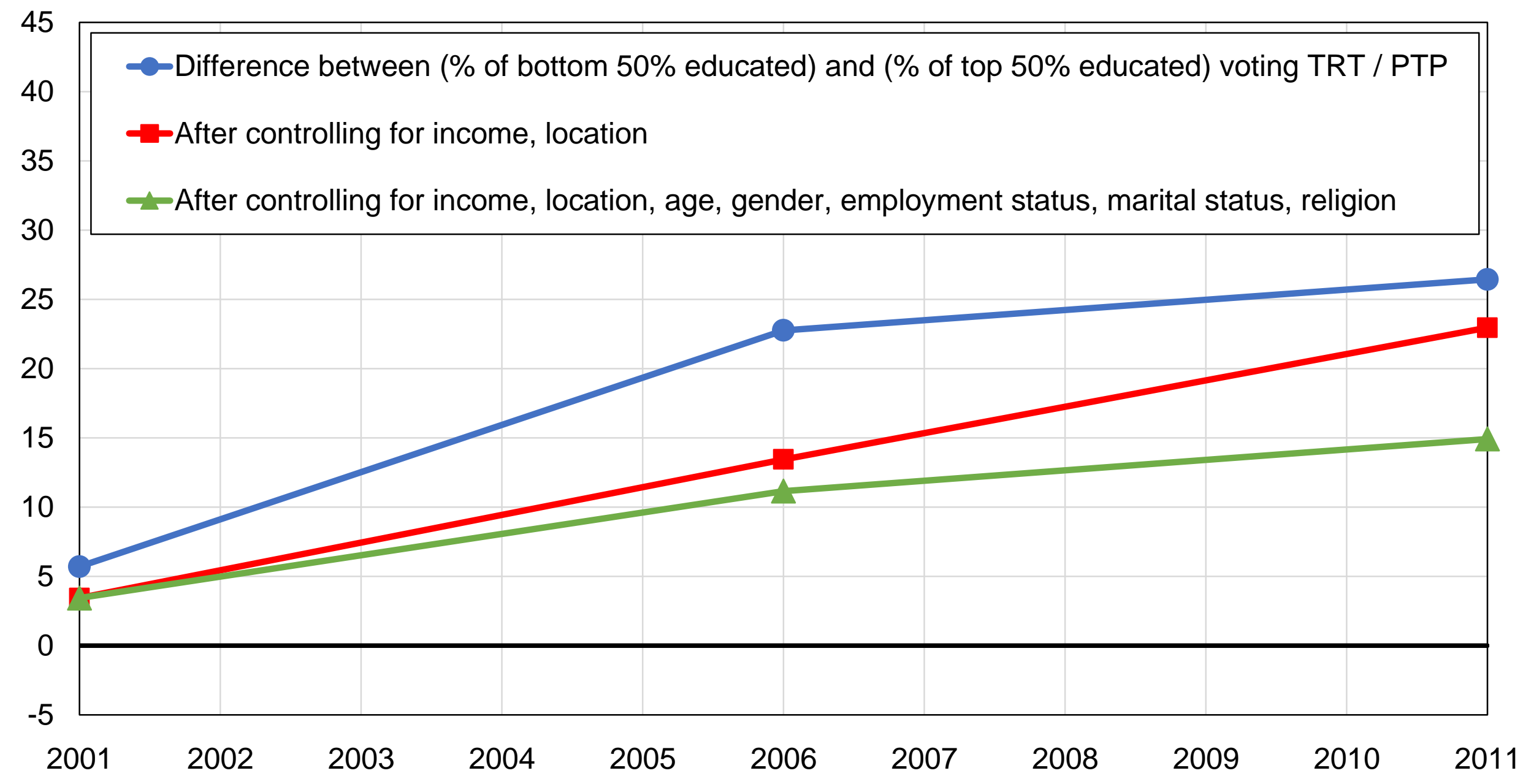

Source: authors' computations using Thai political attitudes surveys (see wpid.world).

Note: the figure shows the difference between the share of bottom $50 \%$ educated voters and the share of top $50 \%$ educated voters voting for the Thai Rak Thai, the Pheu Thai, and other pro-Thaksin parties, before and after controls. In 2001 , bottom $50 \%$ educated voters were 6 percentage points more likely to vote for these parties, compared to 26 percentage points in 2011. 


\section{Figure 4 - The rural-urban cleavage in Thailand, 2001-2011}

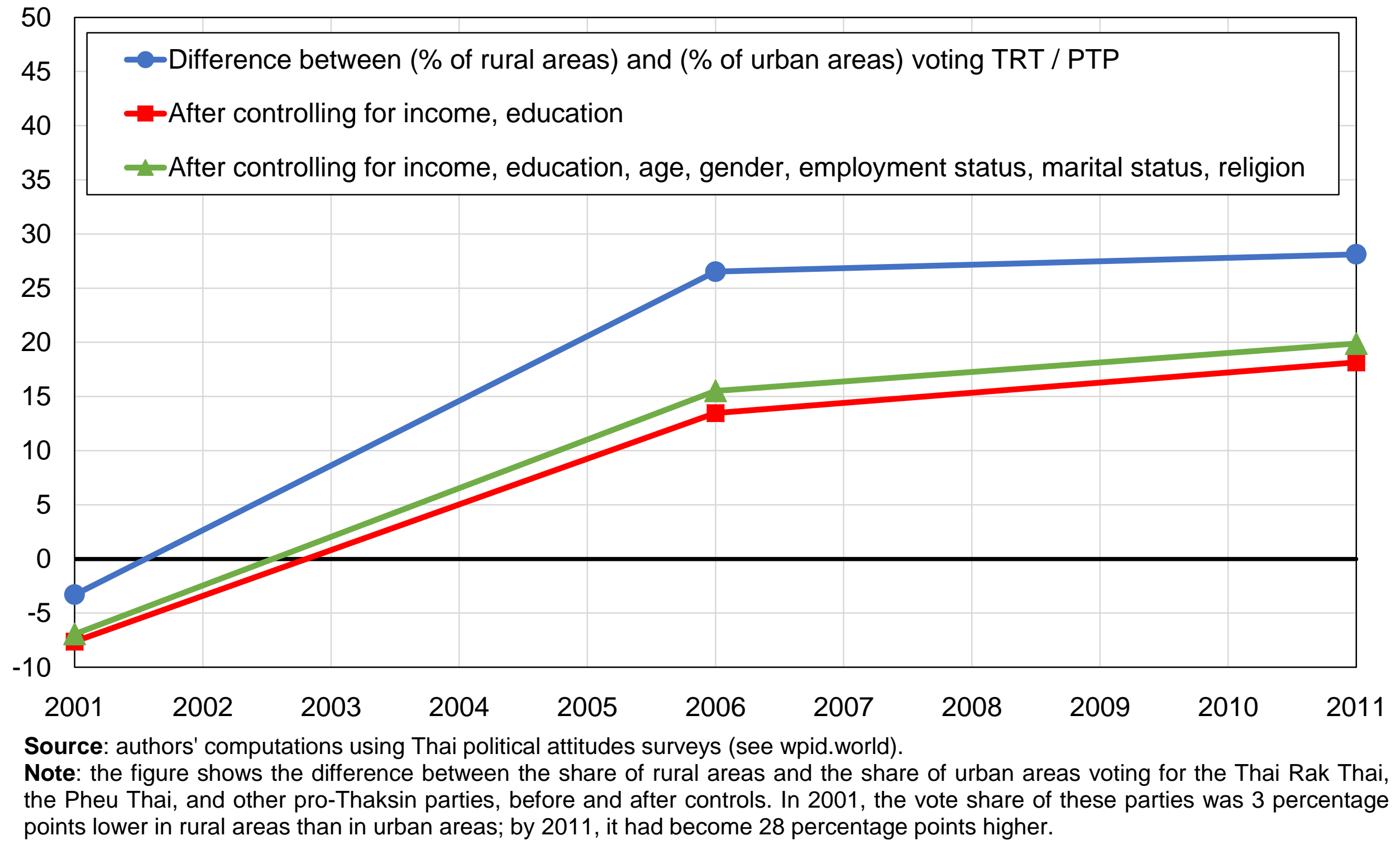


Figure 5 - Election results in the Philippines, 1992-2016

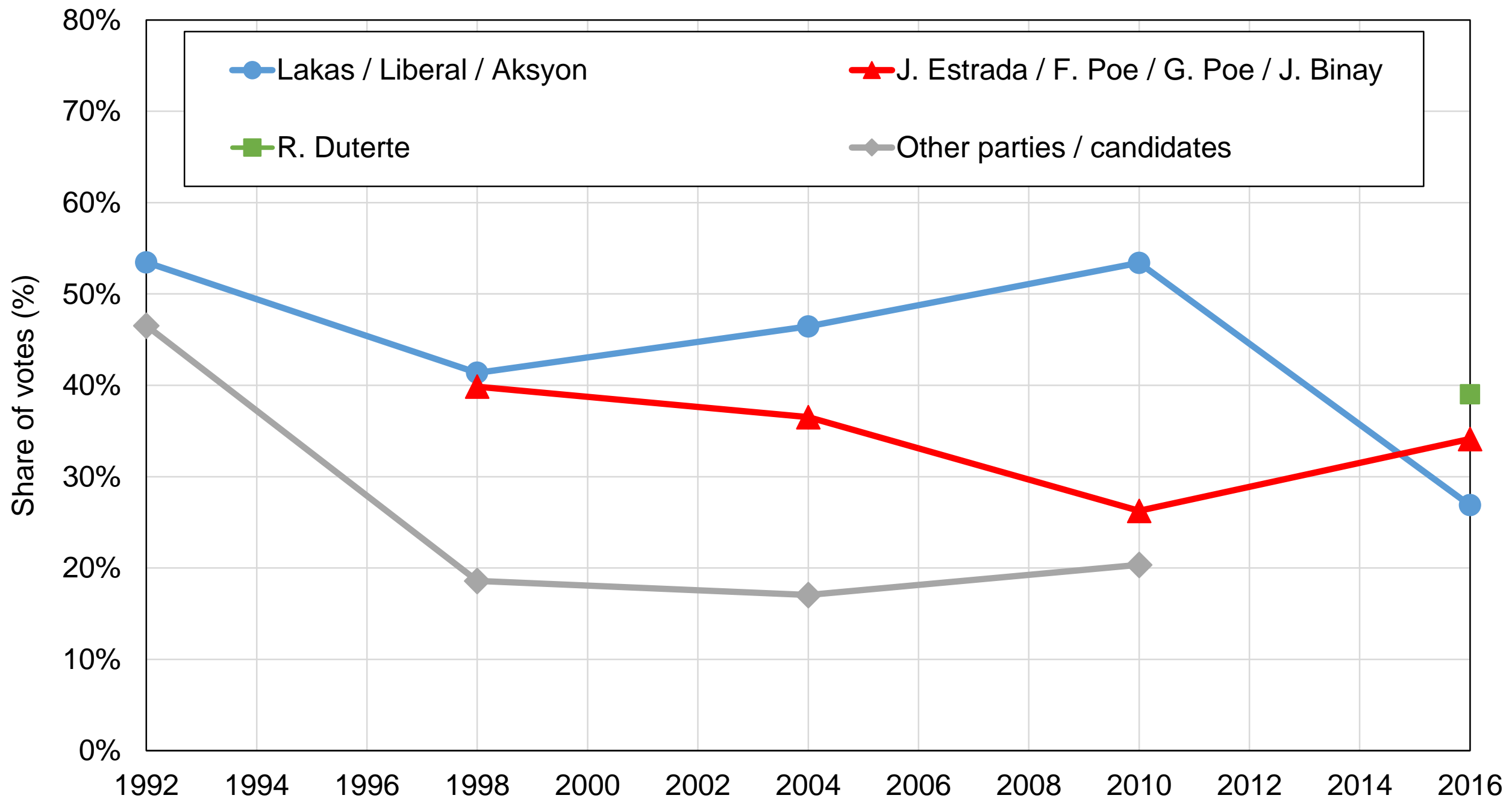

Source: authors' computations using official election results (see wpid.world).

Note: the figure shows the share of votes received in the first round of presidential elections by selected parties, group of parties, or candidates in the Philippines. The candidate Rodrigo Duterte received 39\% of votes in the 2016 election. 


\section{Figure 6 - The educational cleavage in the Philippines, 1998-2016}

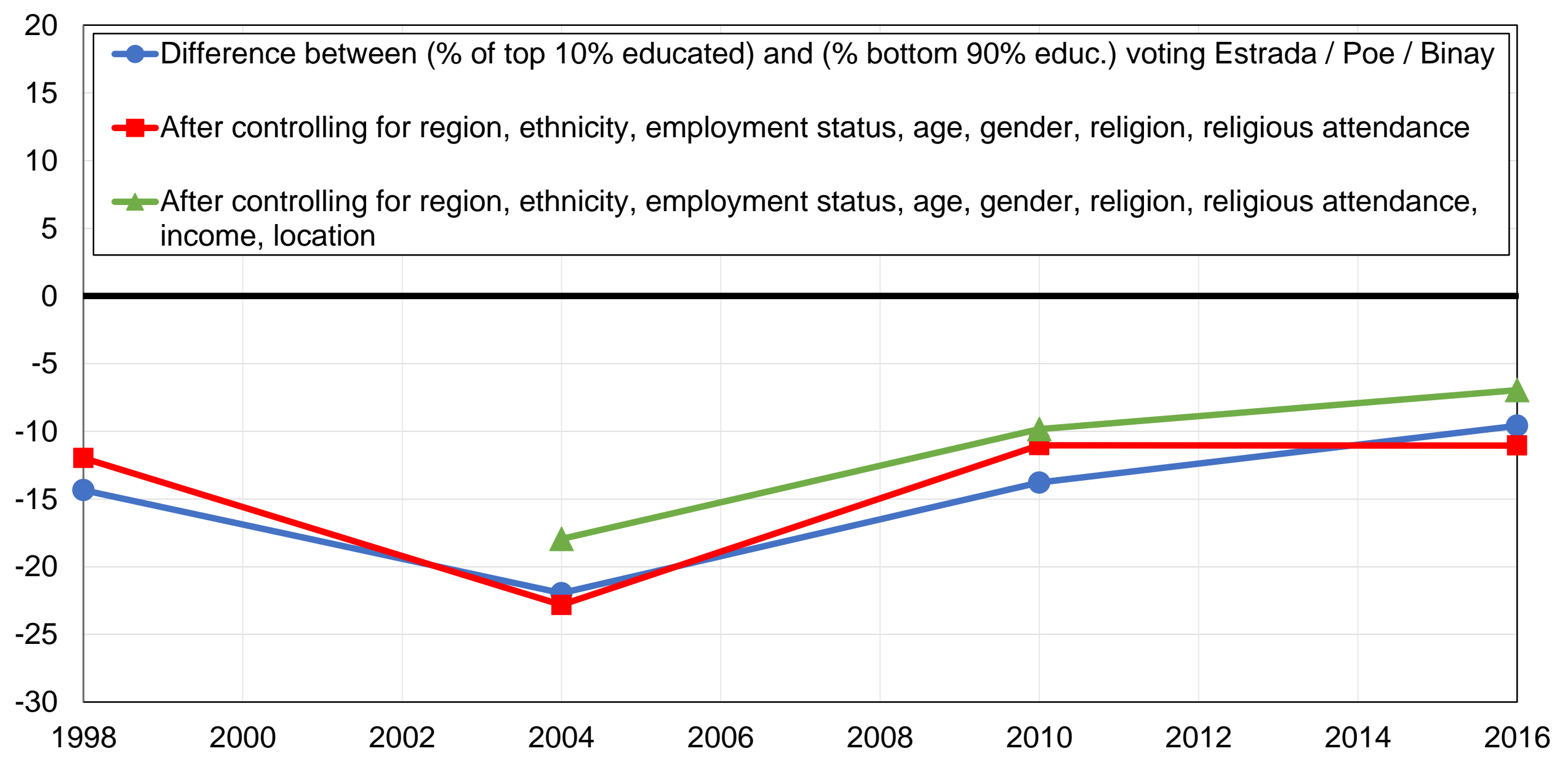

Source: authors' computations using Filipino electoral surveys (see wpid.world).

Note: the figure shows the difference between the share of top $10 \%$ educated voters and the share of bottom $90 \%$ educated voters voting for Joseph Estrada (1998, 2010), Fernando Poe (2004), Grace Poe (2016), and Jejomar Binay (2016) in the first round of presidential elections, before and after controls. These candidates all received higher support among the least educated. In 2004 , higher-educated voters were less likely to vote for Joseph Estrada by 22 percentage points. 


\section{Figure 7 - The regional cleavage in the Philippines, 1998-2016}

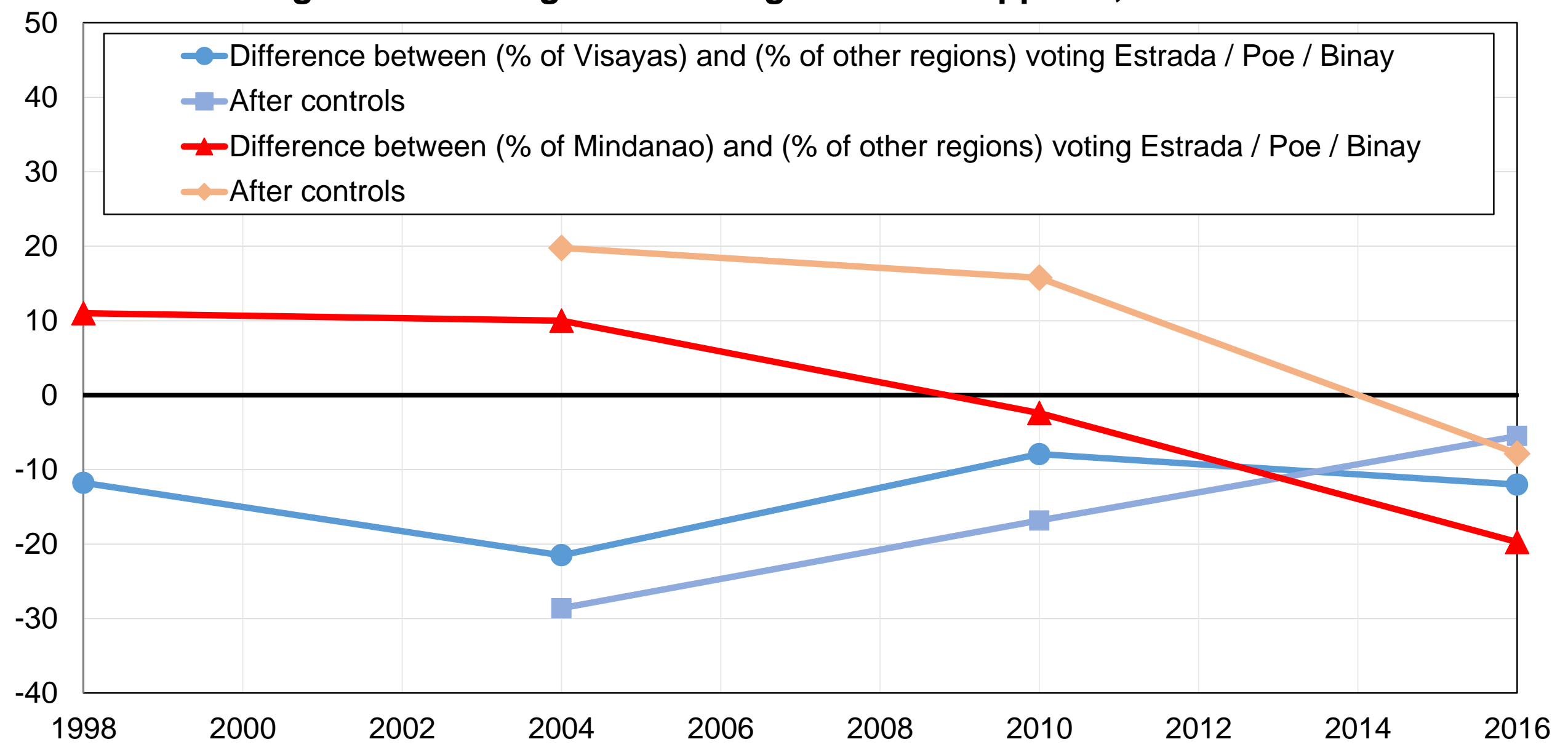

Source: authors' computations using Filipino electoral surveys (see wpid.world).

Note: the figure shows the difference between the share of voters living in the Visayas geographical zone and the share of voters living in other regions of the Philippines voting for the candidates Joseph Estrada (1998, 2010), Fernando Poe (2004), Grace Poe (2016), and Jejomar Binay (2016) in the first round of presidential elections, as well as the same difference between Mindanao and the rest of the country, before and after controlling for education, employment status, age, gender, religion, religious attendance, income, and rural-urban location. In 2016, the vote share of Grace Poe and Jejomar Binay was 20 percentage points lower in Mindanao than in other regions. 
Figure 8 - Election results in Malaysia, 1955-2018

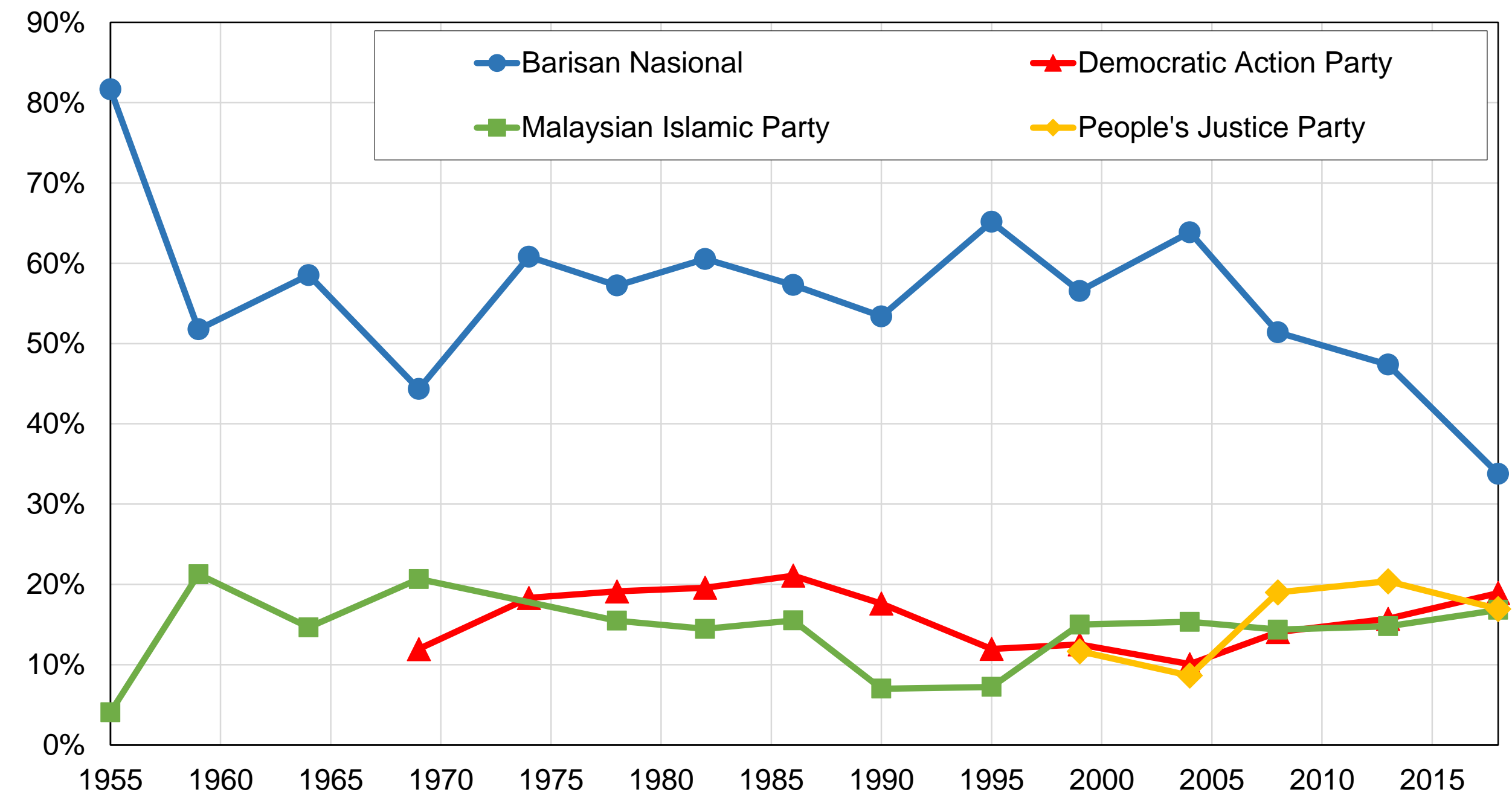

Source: authors' computations using official election results (see wpid.world).

Note: the figure shows the share of votes received by the main Malaysian parties in general elections held between 1955 and 2018. The National Front coalition (Barisan National, BN) received 34\% of the vote in 2018. 


\section{Figure 9 - The ethnoreligious cleavage in Malaysia, 2004-2013 The Barisan National vote by religious affiliation}

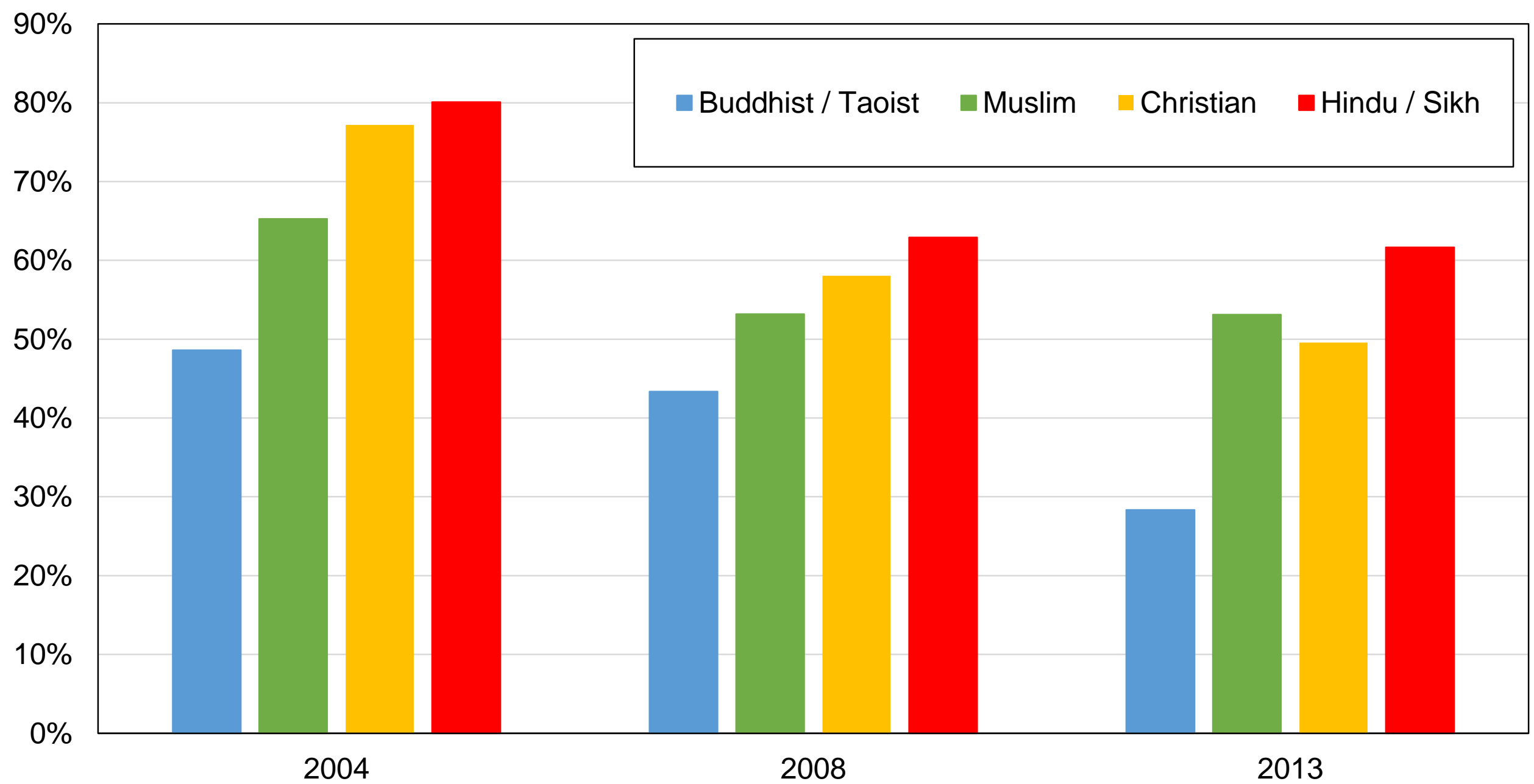

Source: authors' computations using Asian Barometer surveys (see wpid.world).

Note: the figure shows the share of votes received by the Barisan Nasional by religious affiliation. In 2013, 29\% of Buddhist and Taoist voters voted BN, compared to $53 \%$ of Muslim voters and $62 \%$ of Hindu and Sikh voters. 


\section{Figure 10 - Vote and income in Malaysia, 2004-2013}

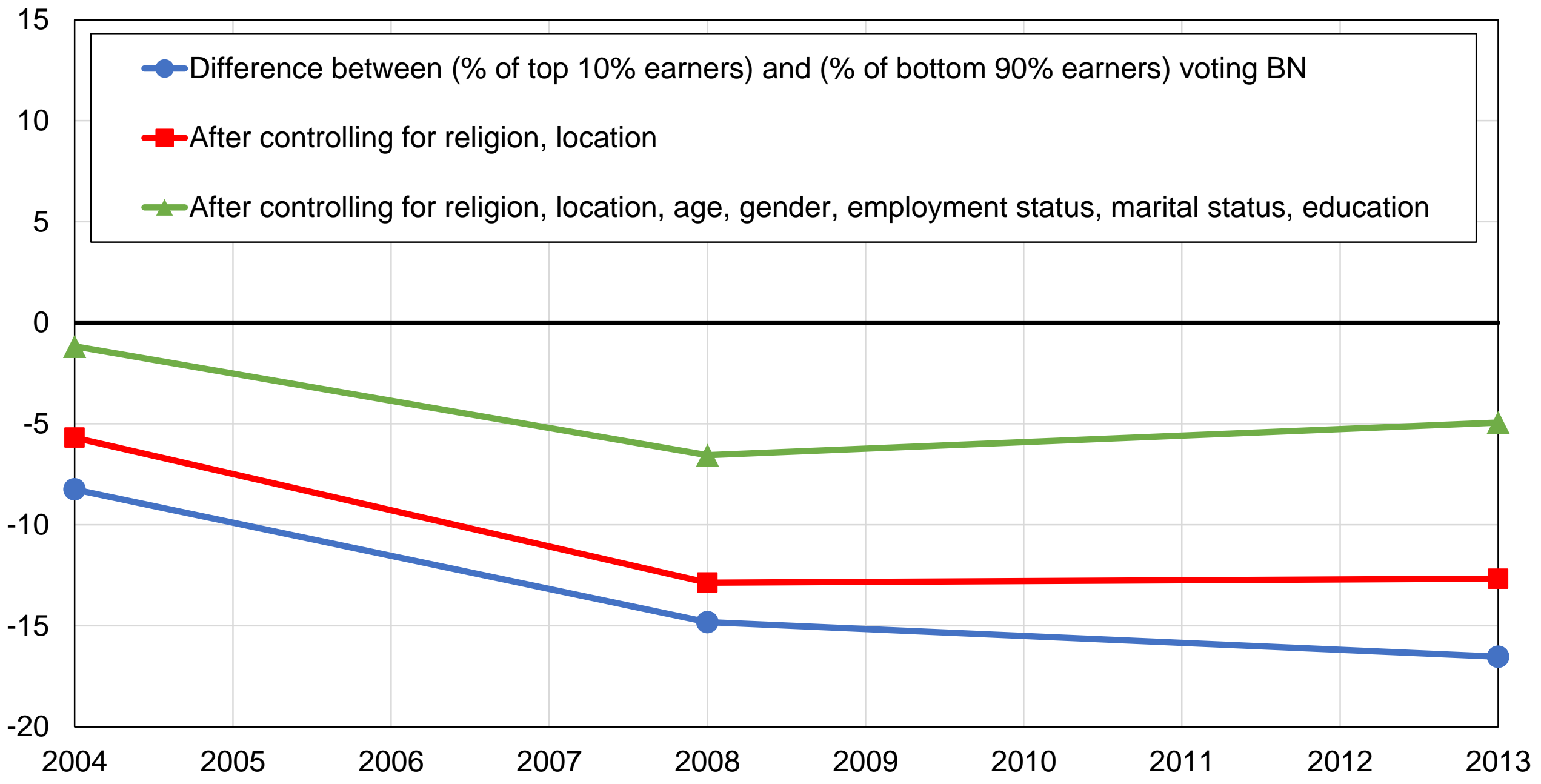

Source: authors' computations using Asian Barometer surveys (see wpid.world).

Note: the figure shows the difference between the share of top $10 \%$ earners and the share of bottom $90 \%$ earners voting for the Barisan Nasional, before and after controls. In 2013, bottom 50\% income earners were 17 percentage points less likely to vote BN. After controls (all other things being equal), this difference is reduced to 5 percentage points. 


\section{Figure 11 - Ethnoreligious cleavages and class cleavages in Malaysia, 2004-2013}

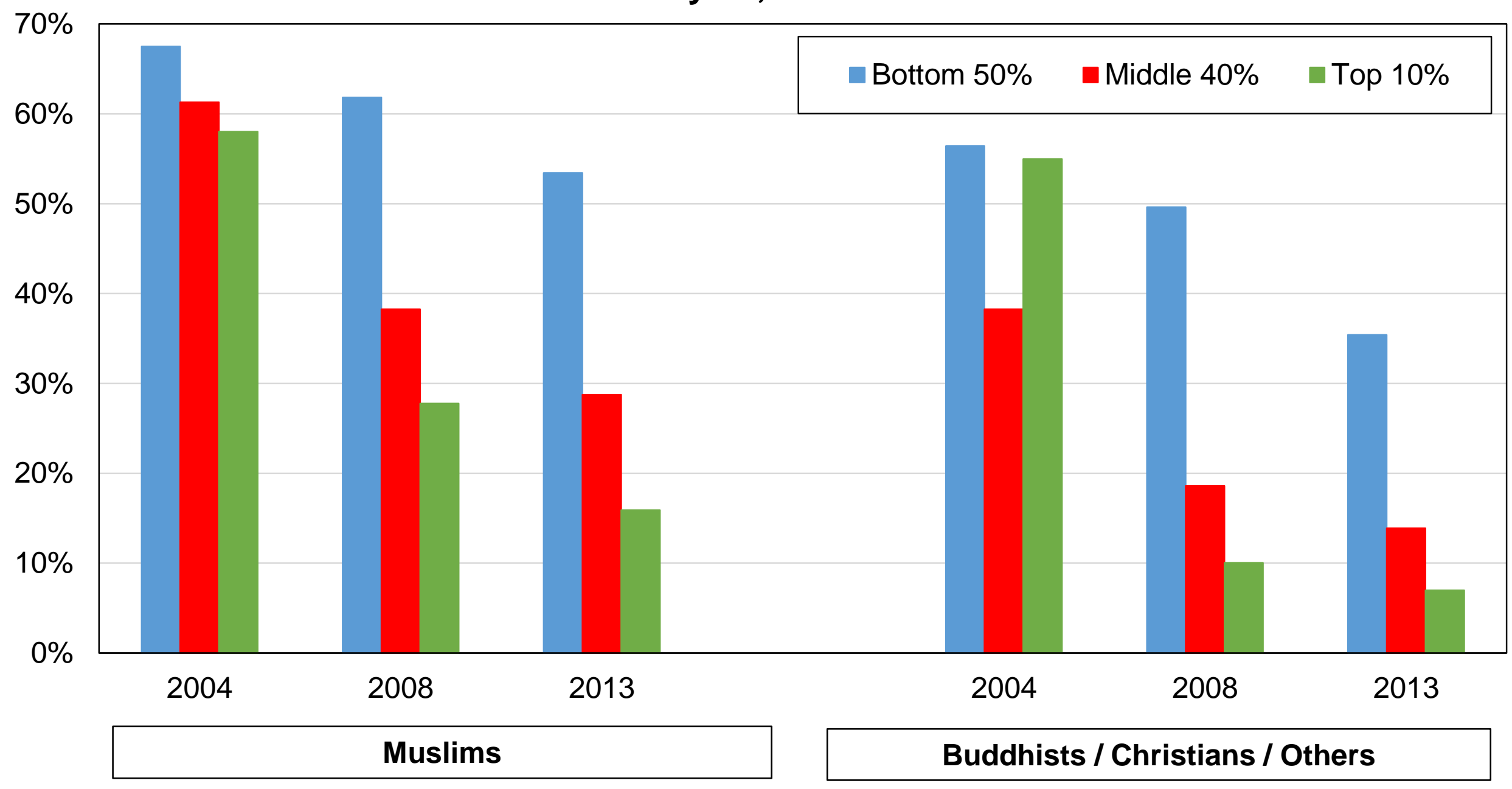

Source: authors' computations using Asian Barometer surveys (see wpid.world).

Note: the figure shows the share of votes received by the Barisan Nasional by income group among Muslims and non-Muslims. The BN has been most strongly supported among bottom 50\% income earners within these two groups. In $2013,53 \%$ of the bottom $50 \%$ of Muslim income earners voted BN, compared to $16 \%$ of the top $10 \%$ of Muslim income earners. 
Figure 12 - Election results in Indonesia, 1977-2019

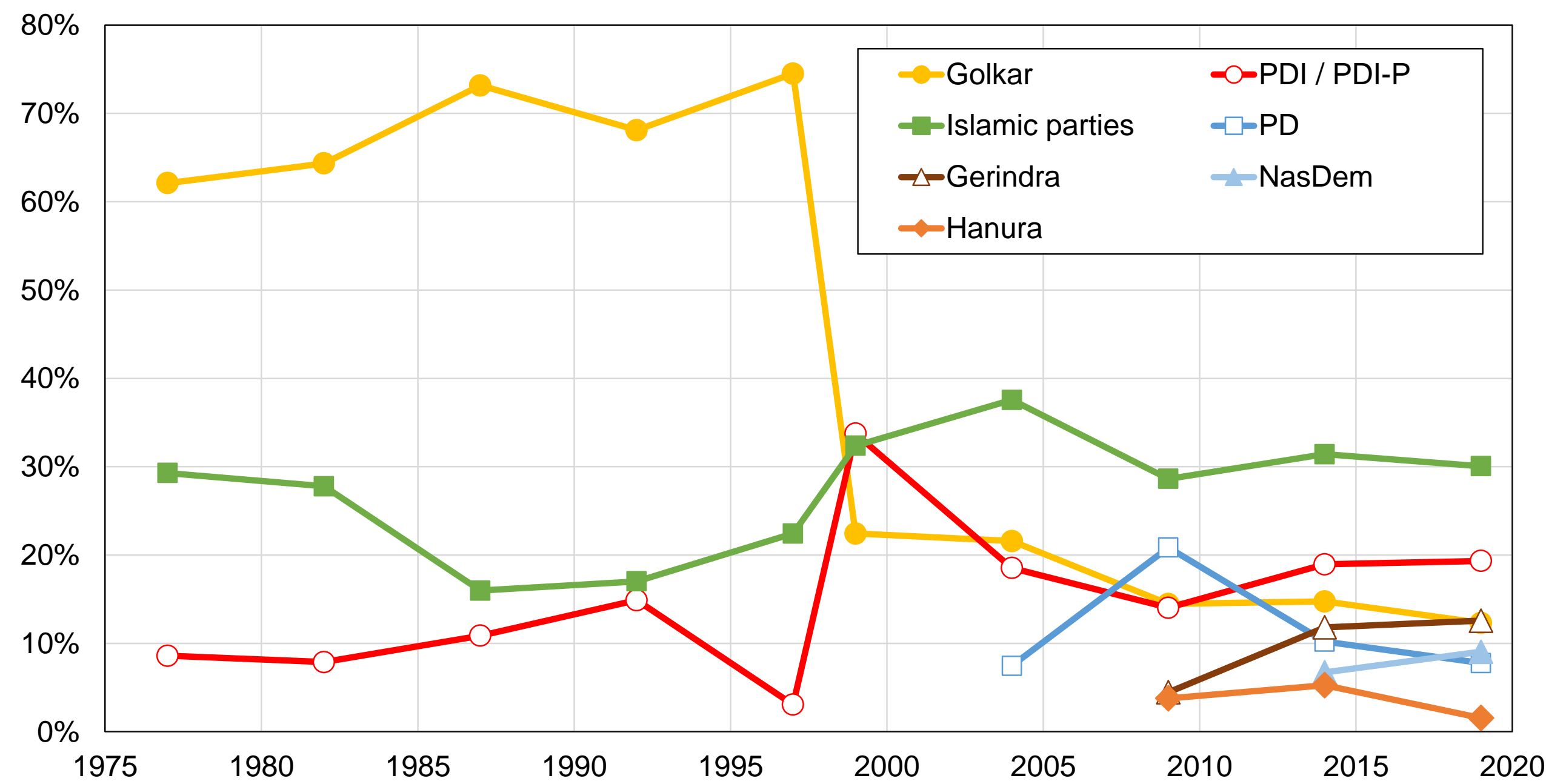

Source: authors' computations using official election results (see wpid.world).

Note: the figure shows the share of votes received by selected Indonesian political parties or groups of parties in legislative elections between 1977 and 2019. The PDI-P received 19\% of votes in 2018. PD: Democratic Party; PDI: Indonesian Democratic Party; PDI-P: Indonesian Democratic Party of Struggle; NasDem: National Democratic Party; Islamic Parties: PAN, PBB, PBR, PKB, PKNU, PKS, and PPP. 


\section{Figure 13 - The PDI-P / NasDem vote by religious affiliation in Indonesia,}

1999-2014

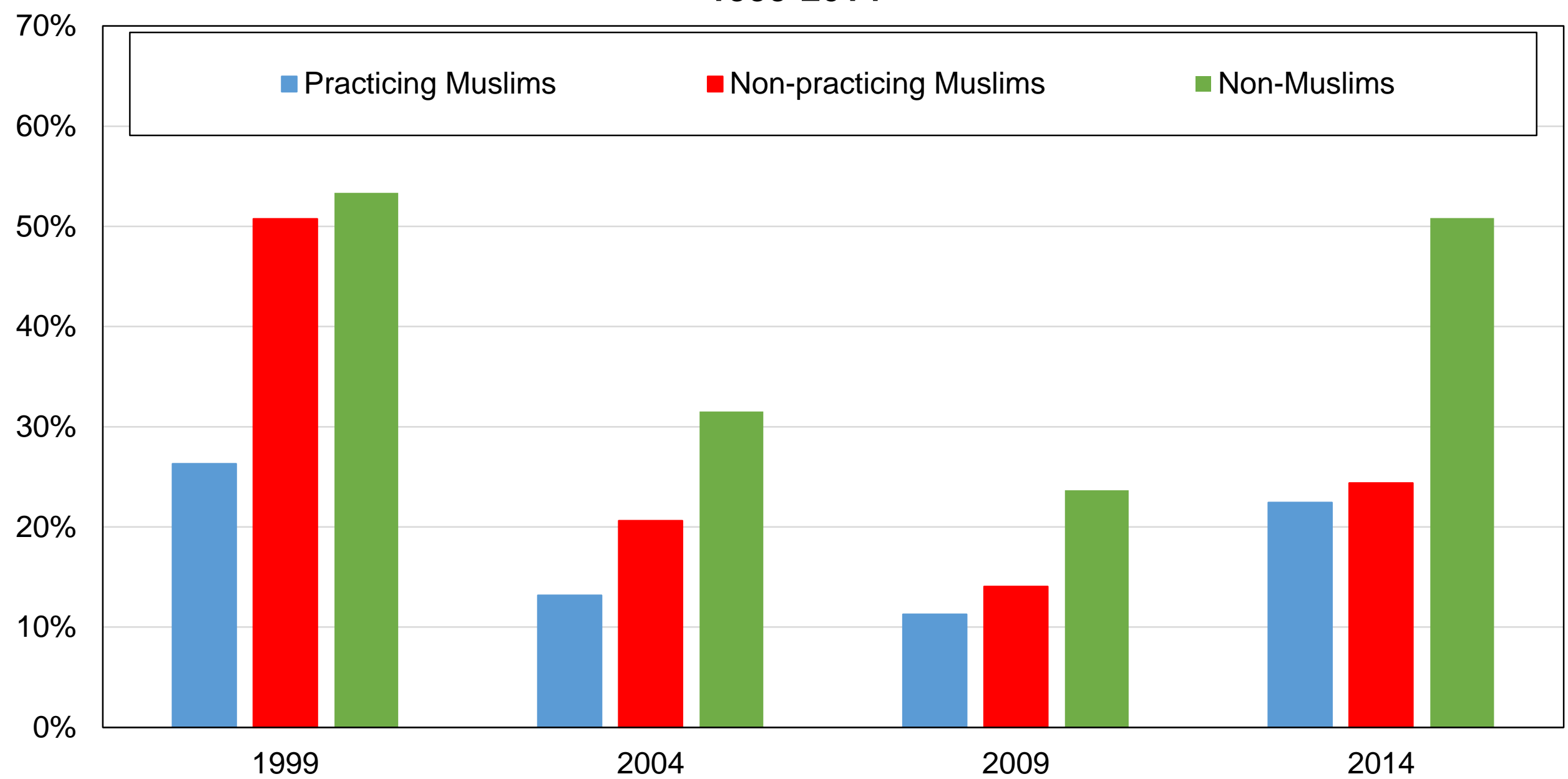

Source: authors' computations using Indonesian electoral surveys (see wpid.world).

Note: the figure shows the share of votes received by the Indonesian Democratic Party of Struggle (PDI-P) and the National Democratic Party (NasDem) by religious affiliation. In 2014, 51\% of non-Muslims supported these two parties, compared to $22 \%$ of practicing Muslims (reporting participating "Often" or "Very often / Always" to collective prayers). 
Figure 14 - The religious cleavage in Indonesia, 1999-2014

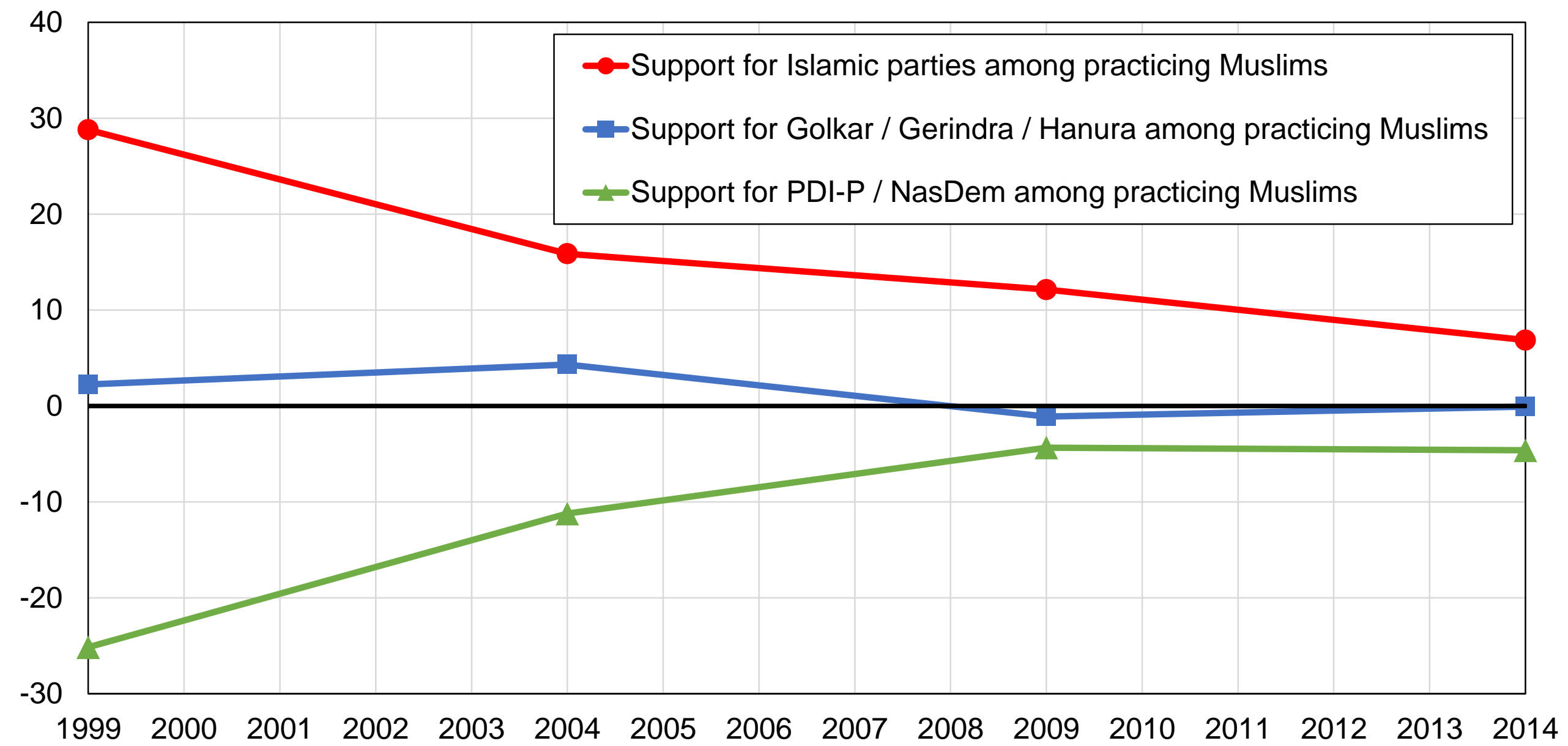

Source: authors' computations using Indonesian electoral surveys (see wpid.world).

Note: the figure shows the difference between the share of practicing Muslims voting for Islamic parties and the share of nonpracticing Muslims and non-Muslims voting for Islamic parties, and the same difference for Golkar / Gerindra / Hanura and PDI-P / NasDem, after controlling for income, education, rural-urban location, employment status, age, and gender. Religious cleavages have weakened in Indonesia in the past decades: practicing Muslims were 25 percentage points less likely to vote PDI-P / NasDem in 1999, compared to 5 percentage points in 2014 . 
Figure 15 - Vote and income in Indonesia, 1999-2014

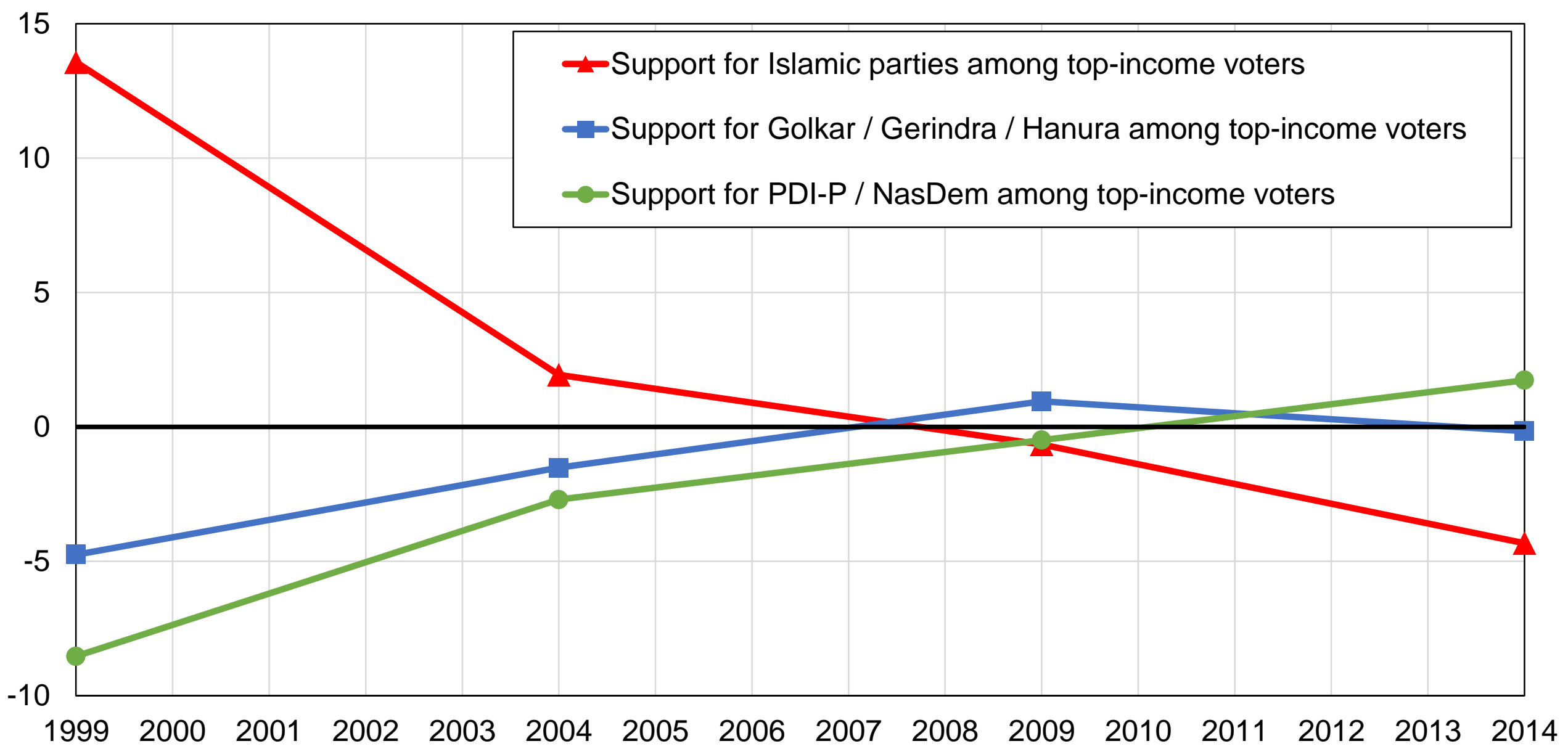

Source: authors' computations using Indonesian electoral surveys (see wpid.world).

Note: the figure shows the difference between the share of top $10 \%$ earners and the share of bottom $90 \%$ earners voting for Islamic parties, and the same difference for Golkar / Gerindra / Hanura and PDI-P / Nasdem, after controlling for religion, education, ruralurban location, employment status, age, and gender. The link between income and the vote has weakened in Indonesia in the past decades: top $10 \%$ earners were 9 percentage points less likely to vote PDI-P / NasDem in 1999, while they were 2 percentage points more likely to do so in 2014. 
Figure AA1 - Election results in Thailand, 1957-2019

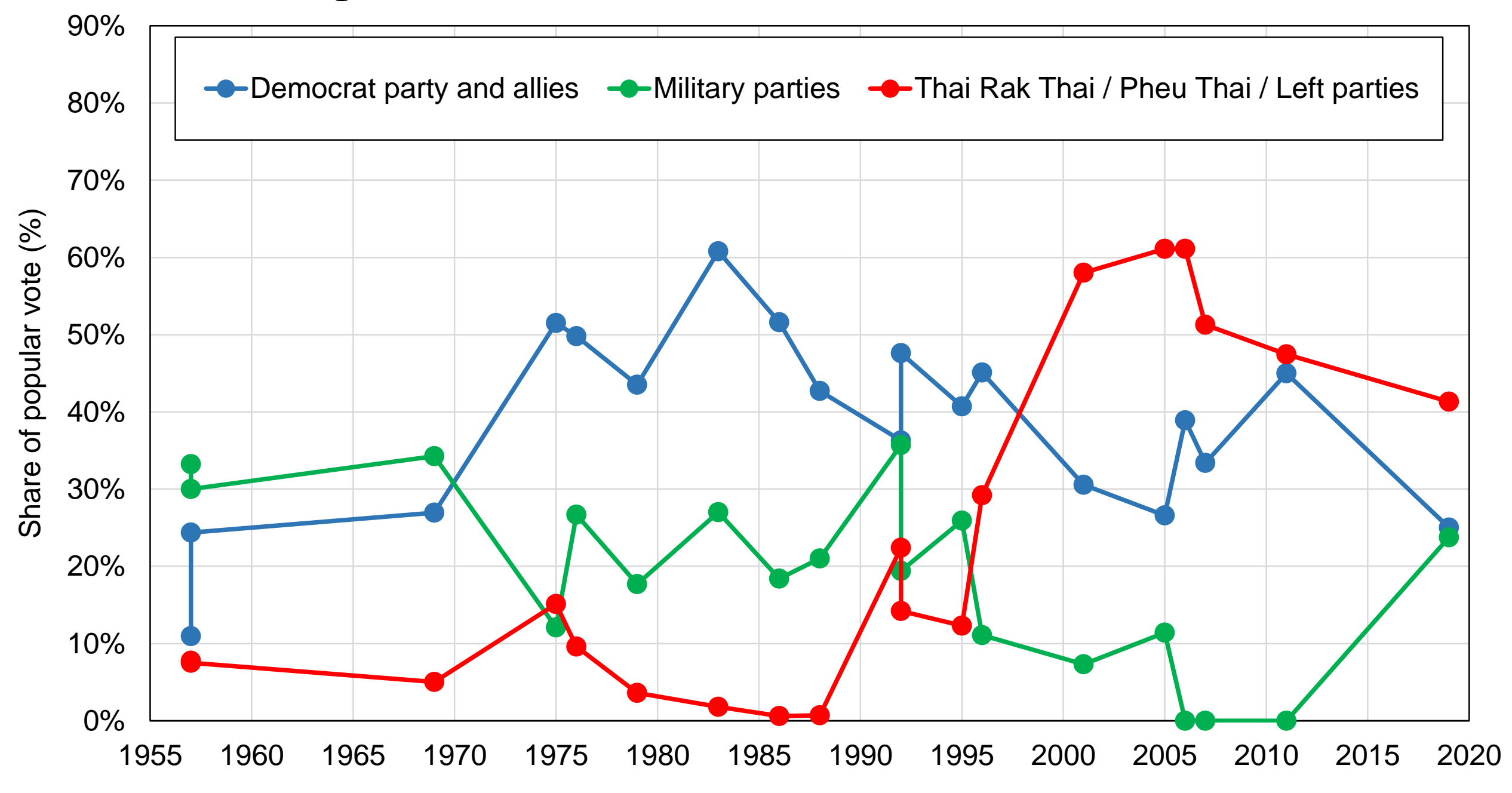

Source: authors' computations using official election results.

Note: the figure shows the share of votes received by selected groups of Thai political parties in general elections between 1957 and 2019. 
Figure AA2 - The composition of the electorate by education

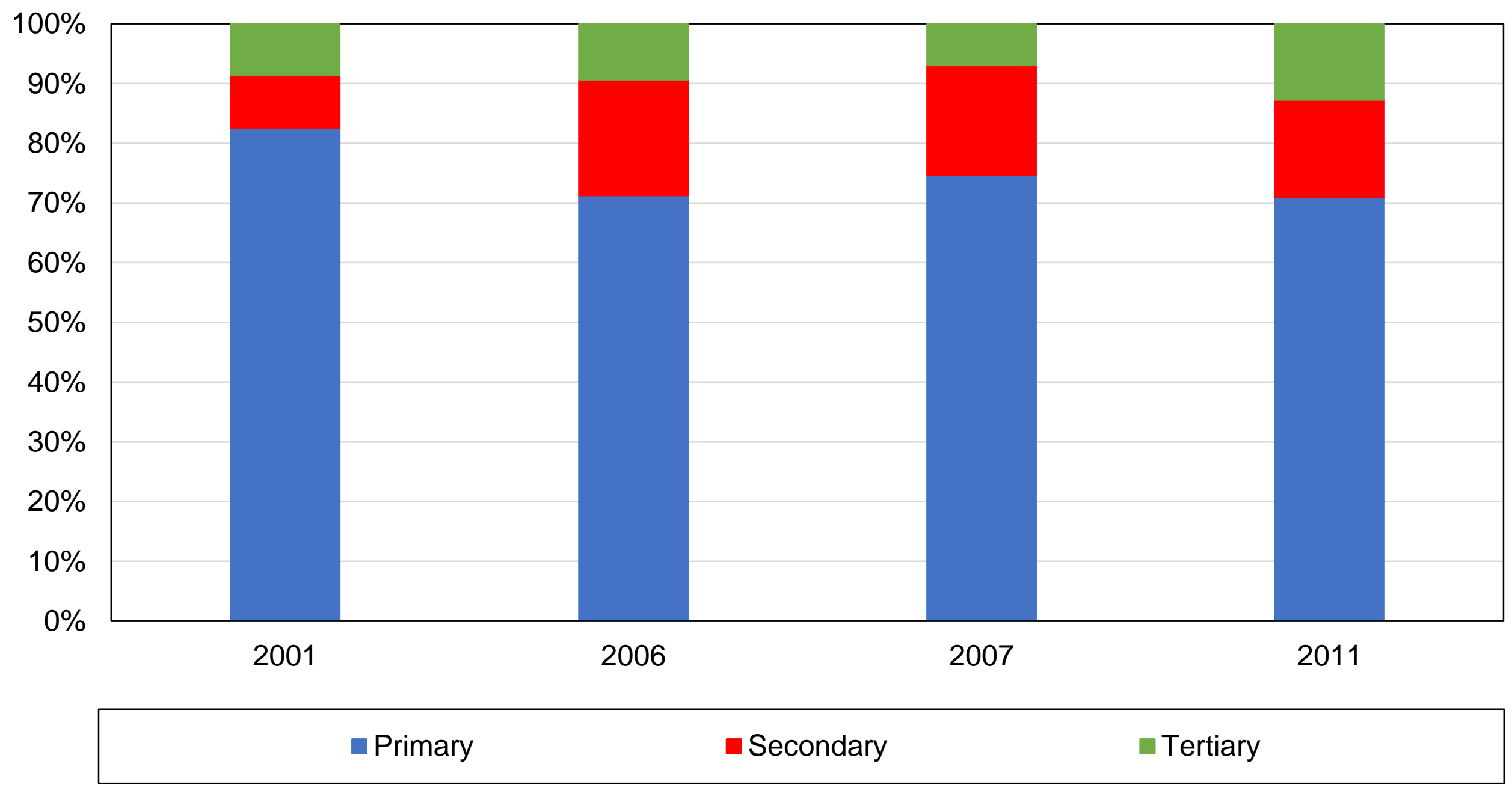

Source: authors' computations using Thai political attitudes surveys.

Note: the figure shows the distribution of education levels of the Thai adult population and its evolution over time. 
Figure AA3 - The composition of the electorate by religion

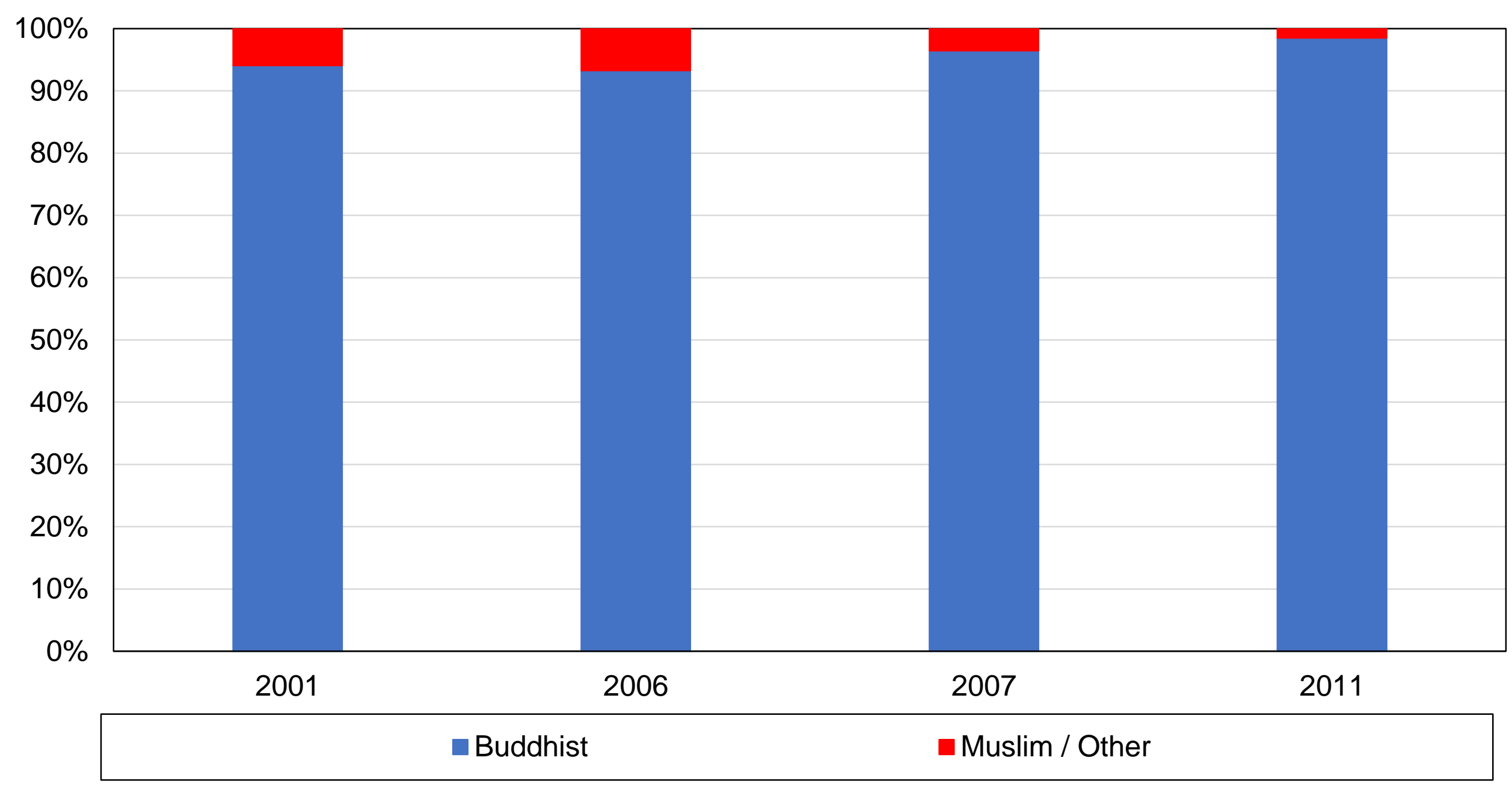

Source: authors' computations using Thai political attitudes surveys.

Note: the figure shows the distribution of religious affiliations in the Thai adult population and its evolution over time. 
Figure AA4 - The composition of the electorate by region, 2011

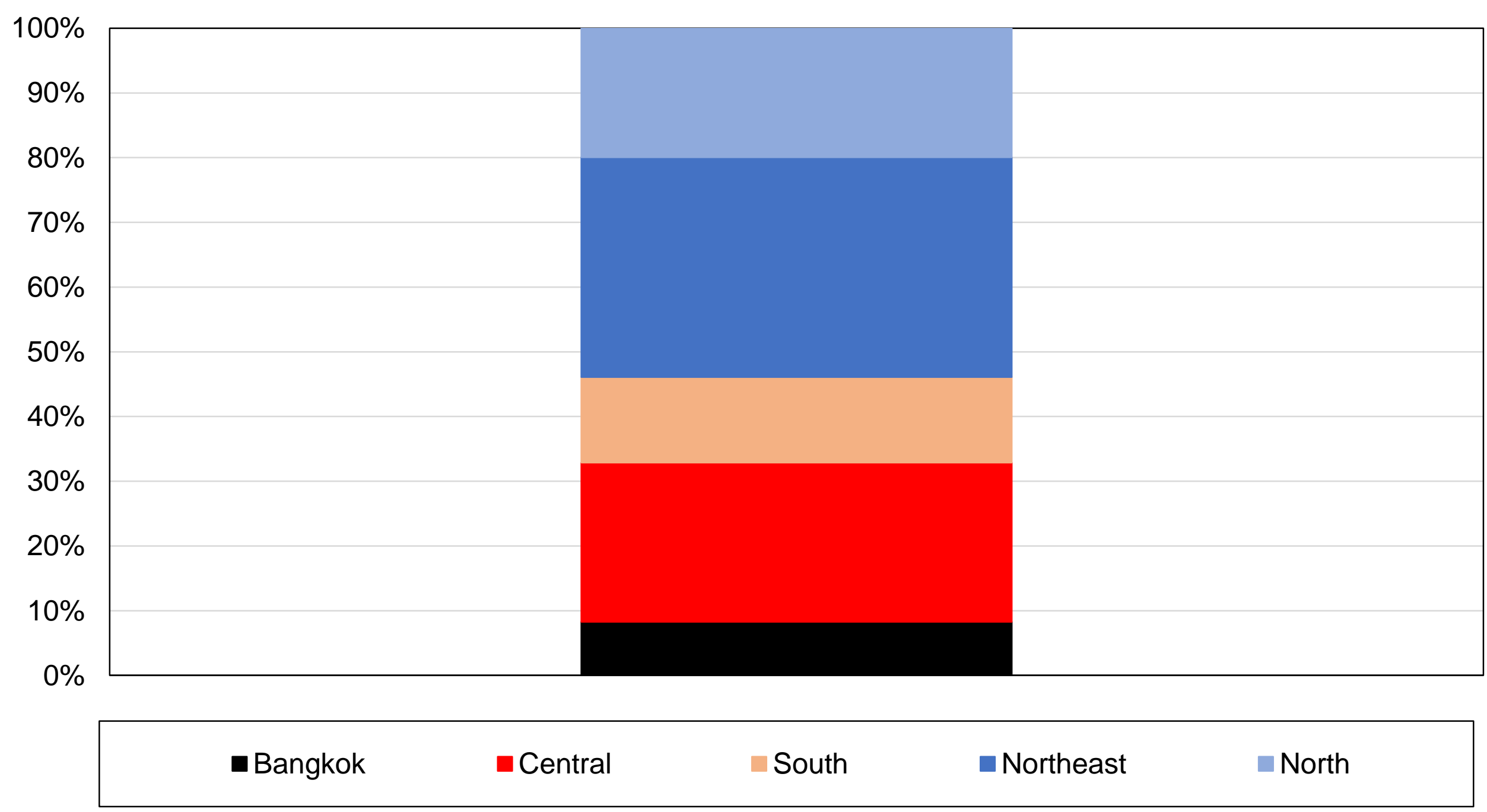

Source: authors' computations using Thai political attitudes surveys.

Note: the figure shows the share of the electorate living in different regions of Thailand in 2011. 
Figure AA5 - Thai regional inequality in comparative perspective

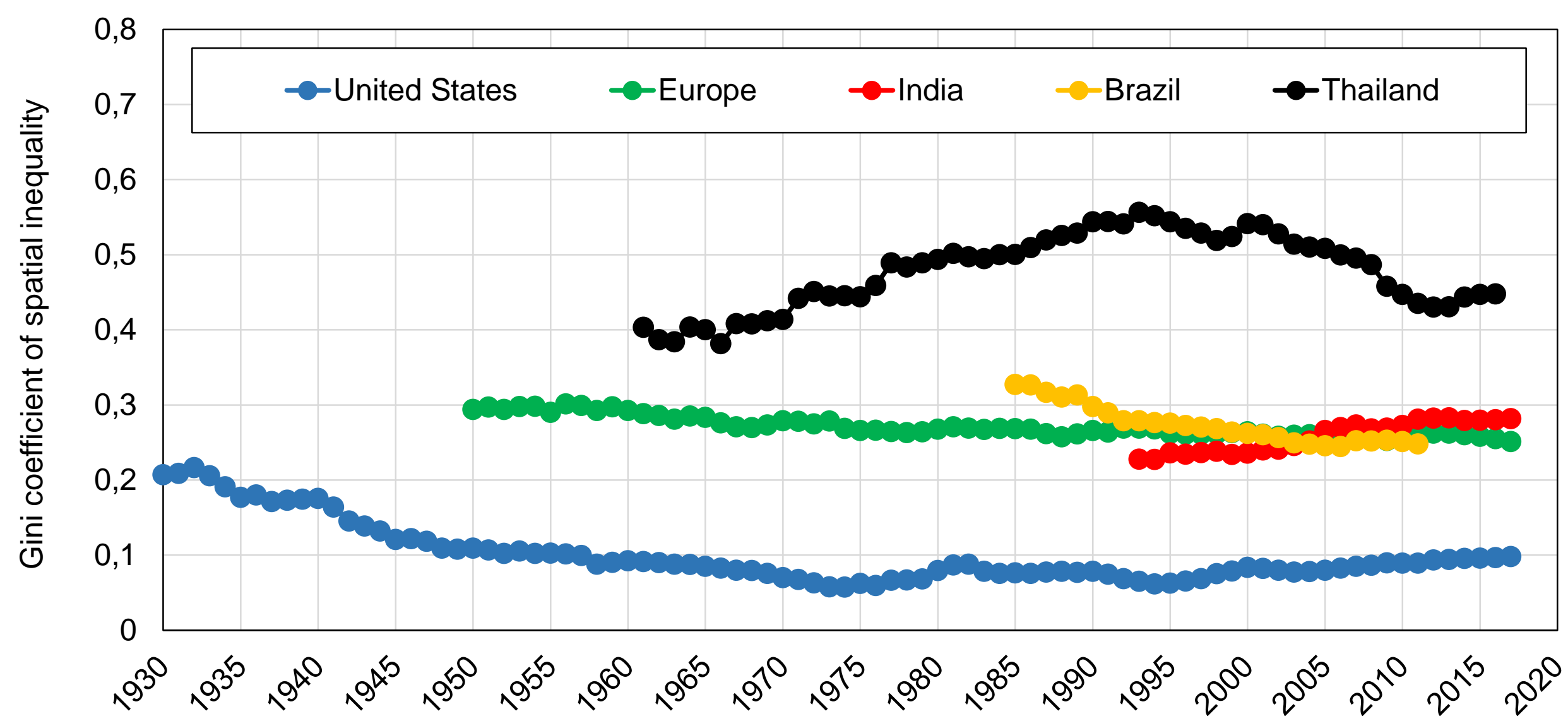

Source: authors' computations combining national and regional accounts statistics from the National Economic and Social Development Board (Thailand), the Brazilian Institute for Geography and Statistics (Brazil), the Bureau of Economic Analysis (United States), the Central Statistics Office (India) and the World Inequality Database (Europe). Spatial units refers to Thai provinces, Brazilian states, US States, Indian States, and European countries (38 countries).

Note: the figure shows the Gini coefficient of regional inequality. 
Figure AA6 - Regional inequality in Thailand, 1961-2016

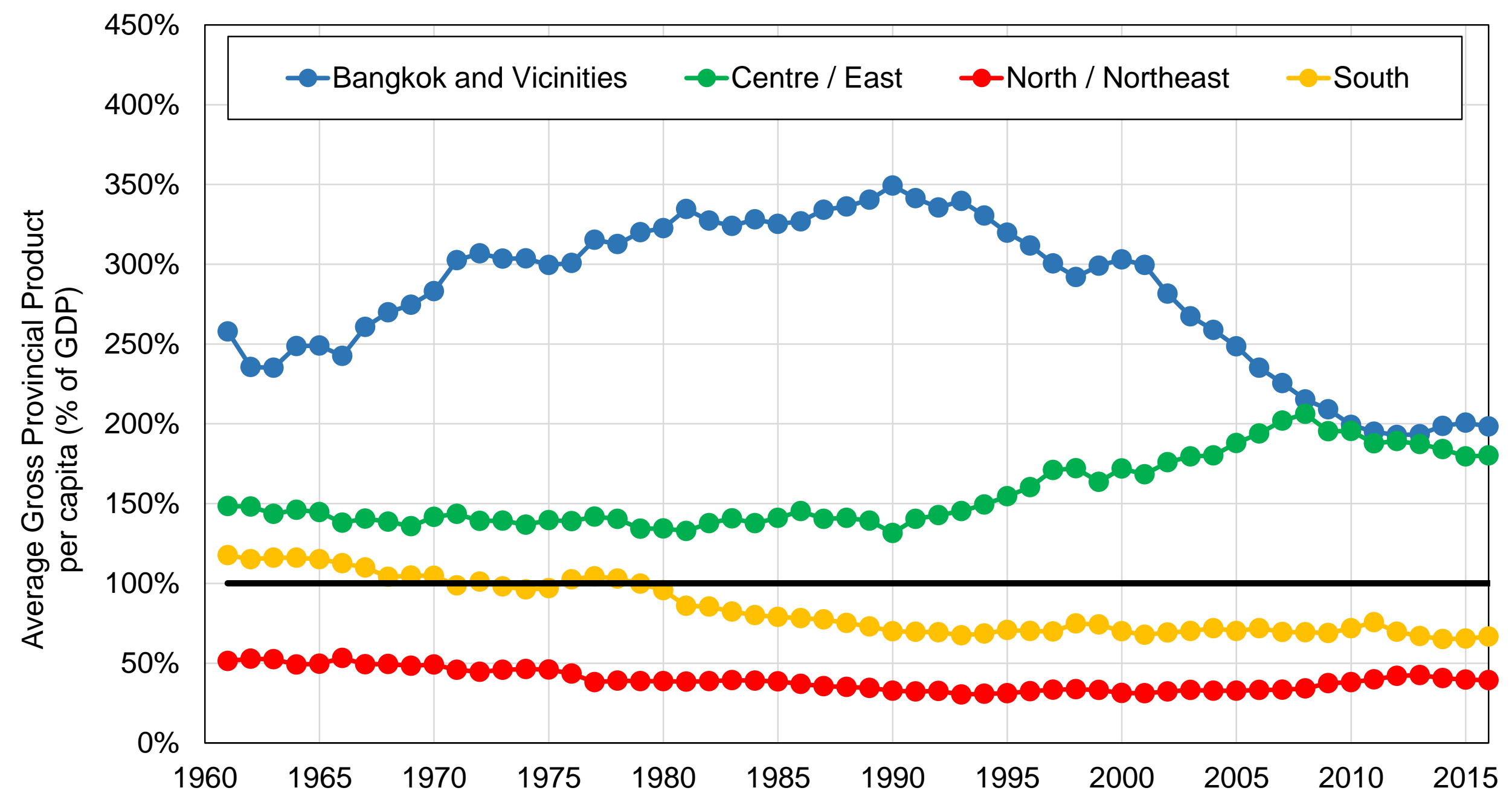

Source: authors' computations using regional accounts statistics.

Note: the figure plots the average gross provincial product per capita of Thai regions relative to the overall Thai GDP per capita between 1961 and 2017. 
Figure AA7 - Regional composition of income deciles, 2011

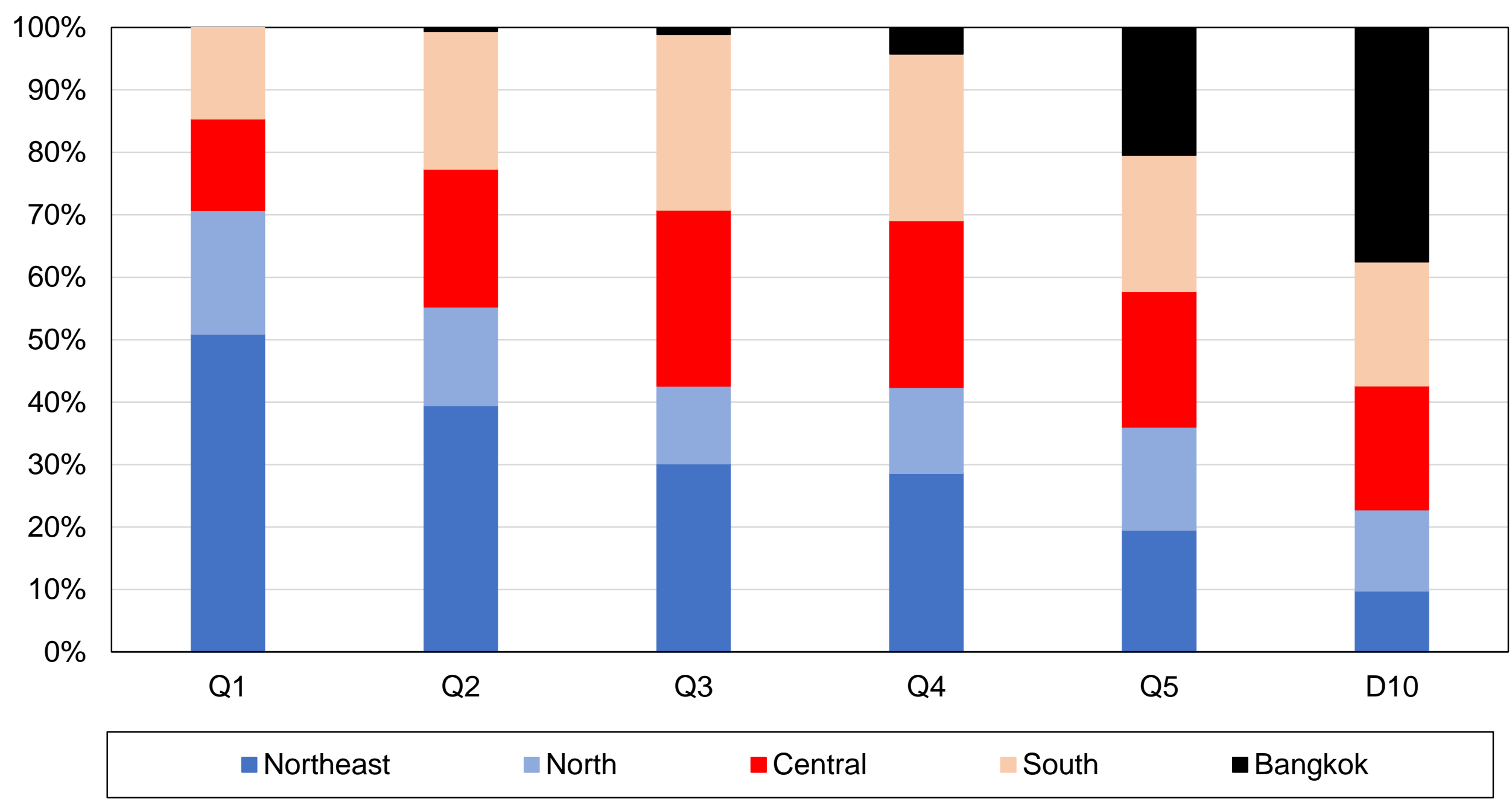

Source: authors' computations using Thai political attitudes surveys.

Note: the figure shows the distribution of income groups by region in 2011. 
Figure AA8 - Rural-urban composition of income deciles, 2001

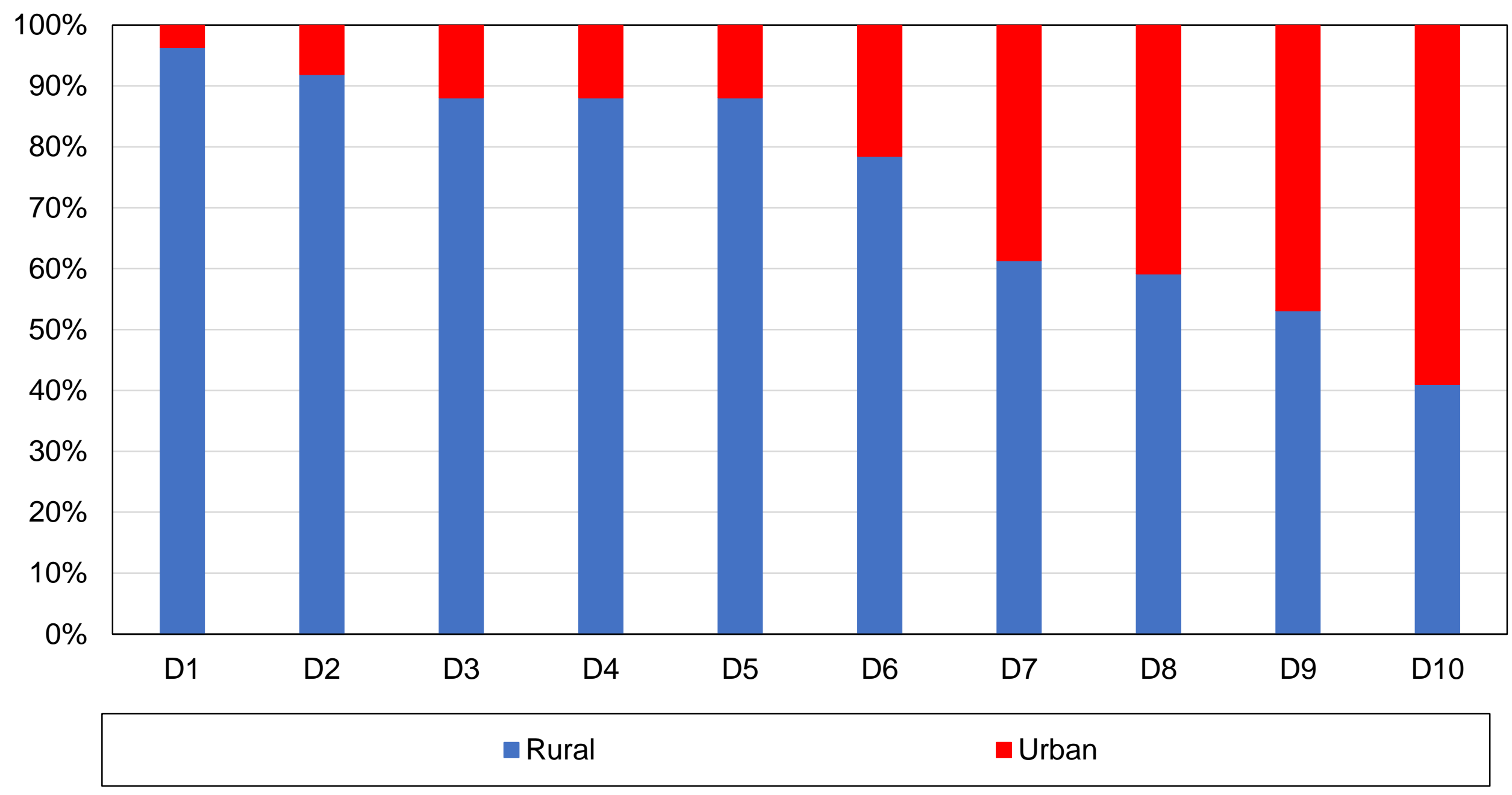

Source: authors' computations using Thai political attitudes surveys.

Note: the figure shows the distribution of income groups by location in 2001. 
Figure AA9 - Rural-urban composition of income deciles, 2011

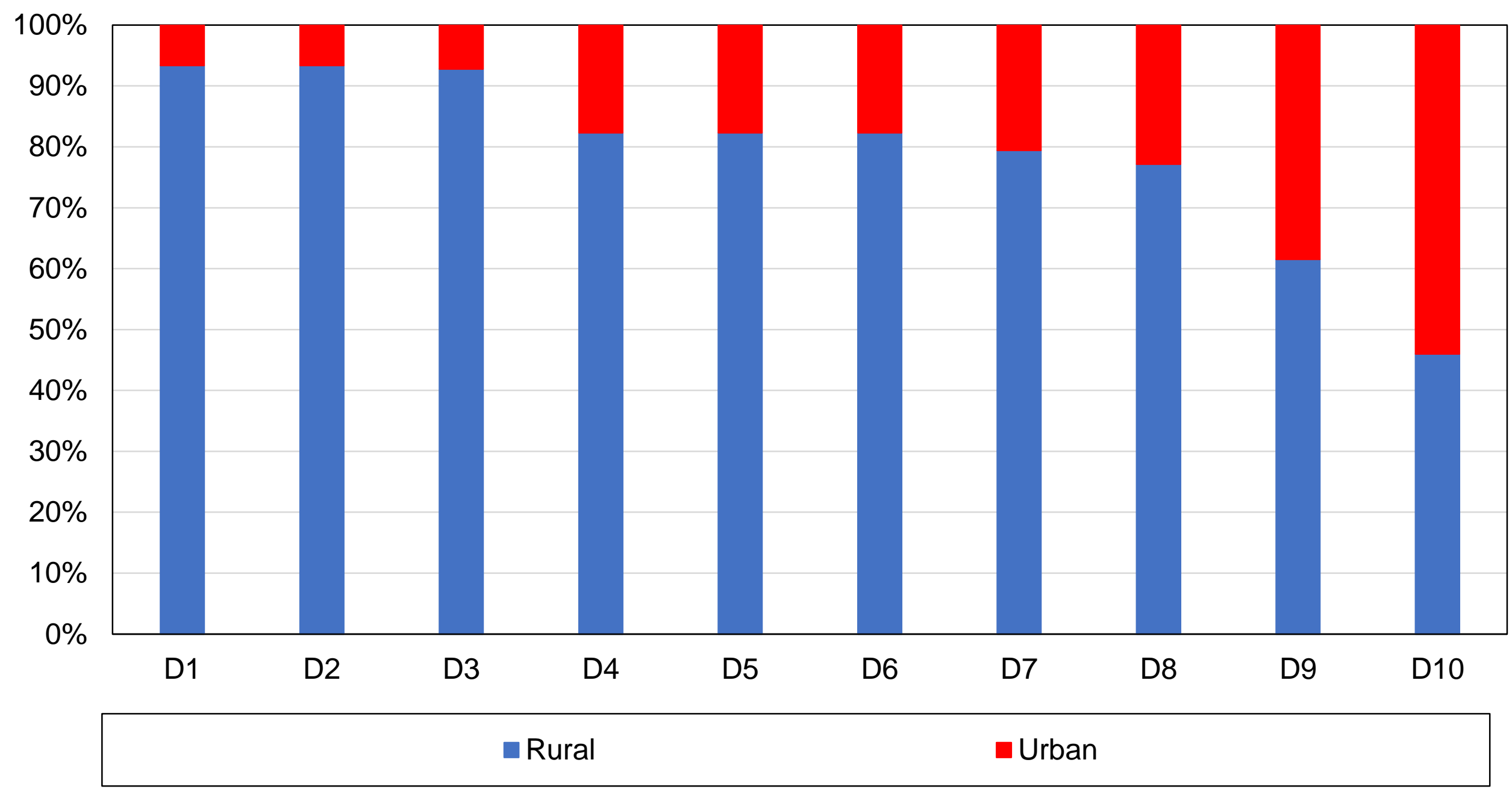

Source: authors' computations using Thai political attitudes surveys.

Note: the figure shows the distribution of income groups by location in 2011 . 
Figure AA10 - Educational composition of income deciles, 2001

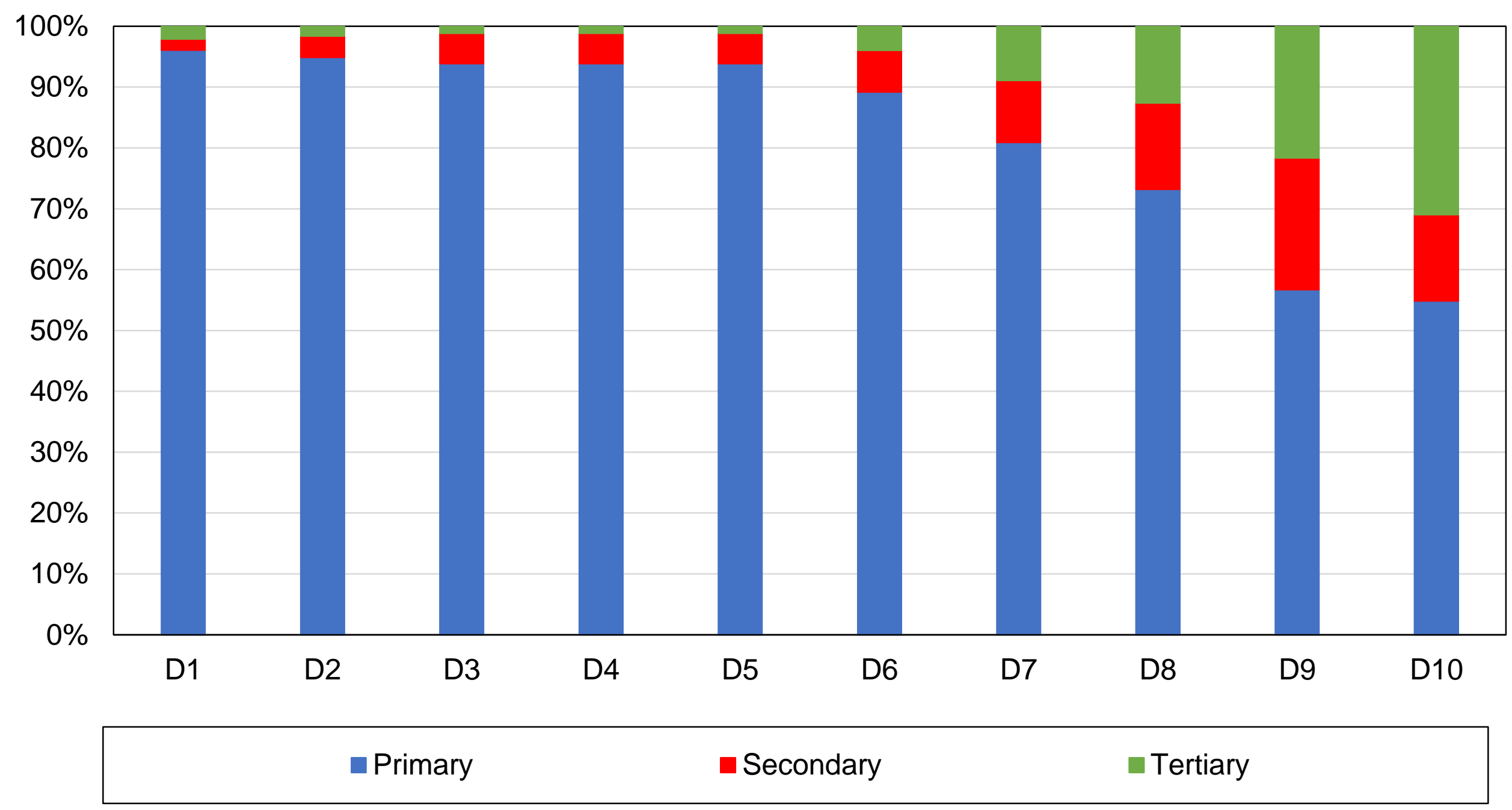

Source: authors' computations using Thai political attitudes surveys.

Note: the figure shows the distribution of income groups by education level of the Thai population in 2001. 
Figure AA11 - Educational composition of income deciles, 2011

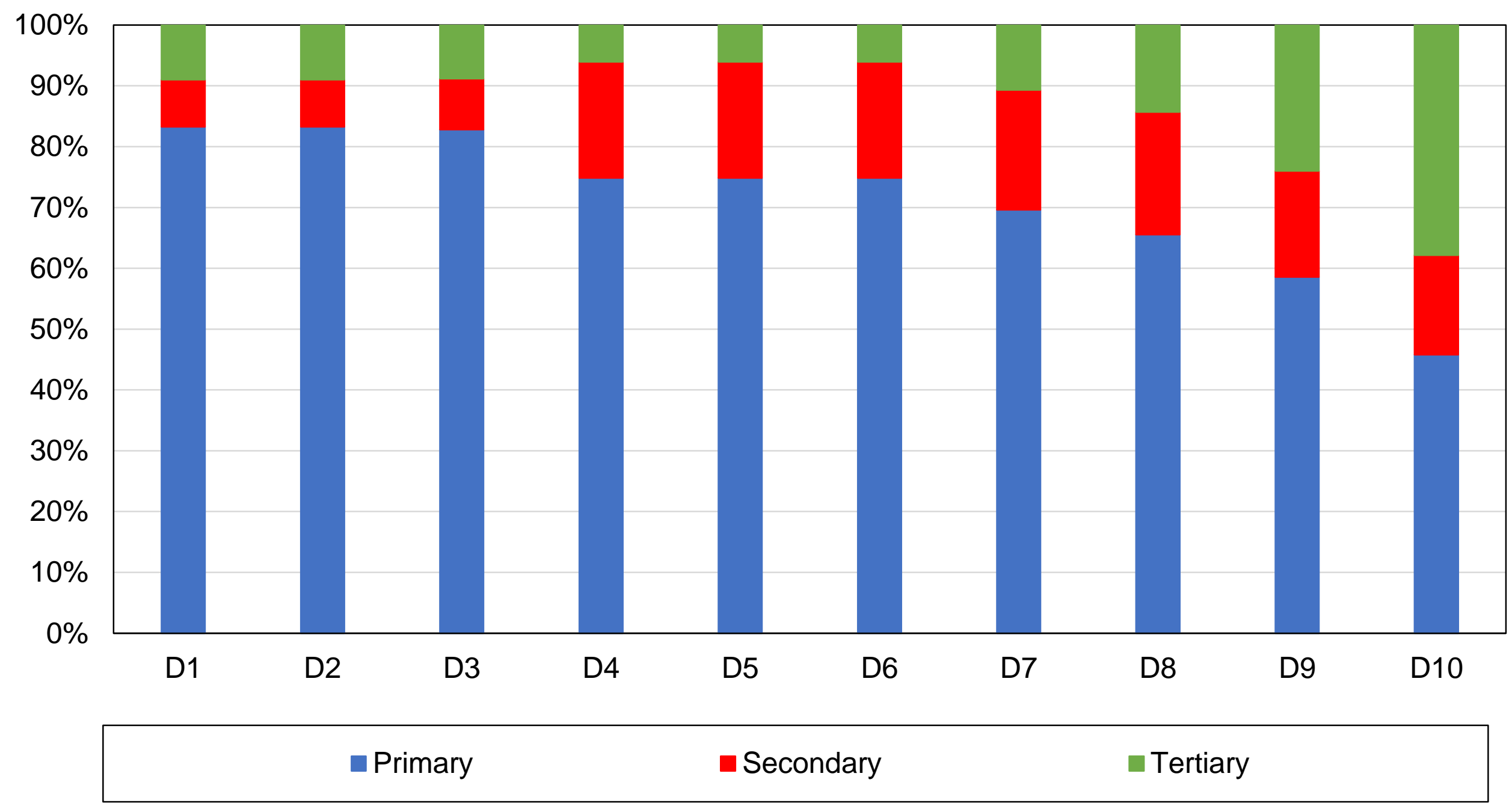

Source: authors' computations using Thai political attitudes surveys.

Note: the figure shows the distribution of income groups by education level of the Thai population in 2011. 
Figure AB1 - Vote for TRT / PT / Other pro-Thaksin by education level

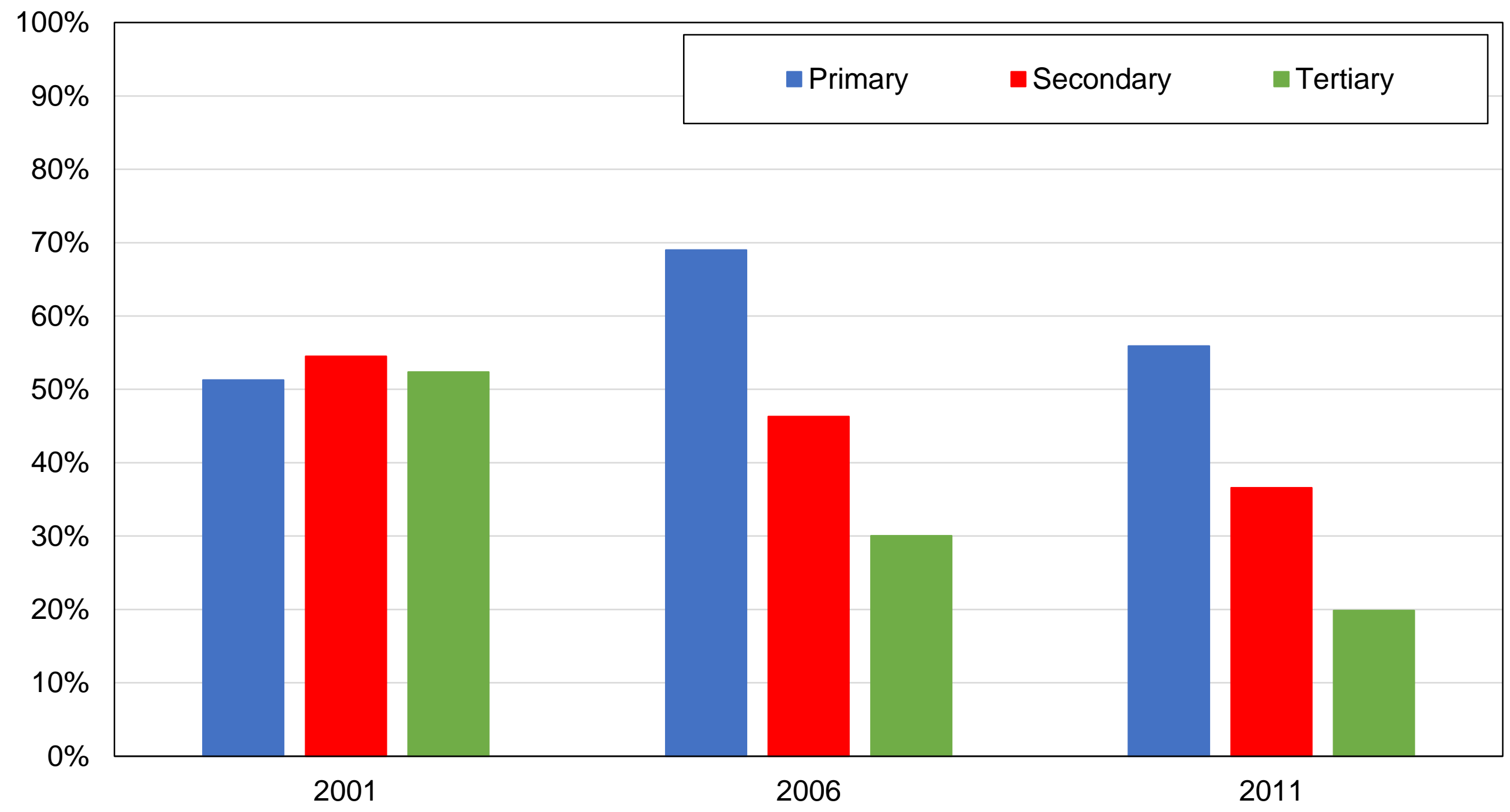

Source: authors' computations using Thai political attitudes surveys.

Note: the figure shows the share of votes received by Thai Rak Thai / Pheu Thai / Other pro-Thaksin parties by education level. 
Figure AB2 - Vote for TRT / PT / Other pro-Thaksin by education group

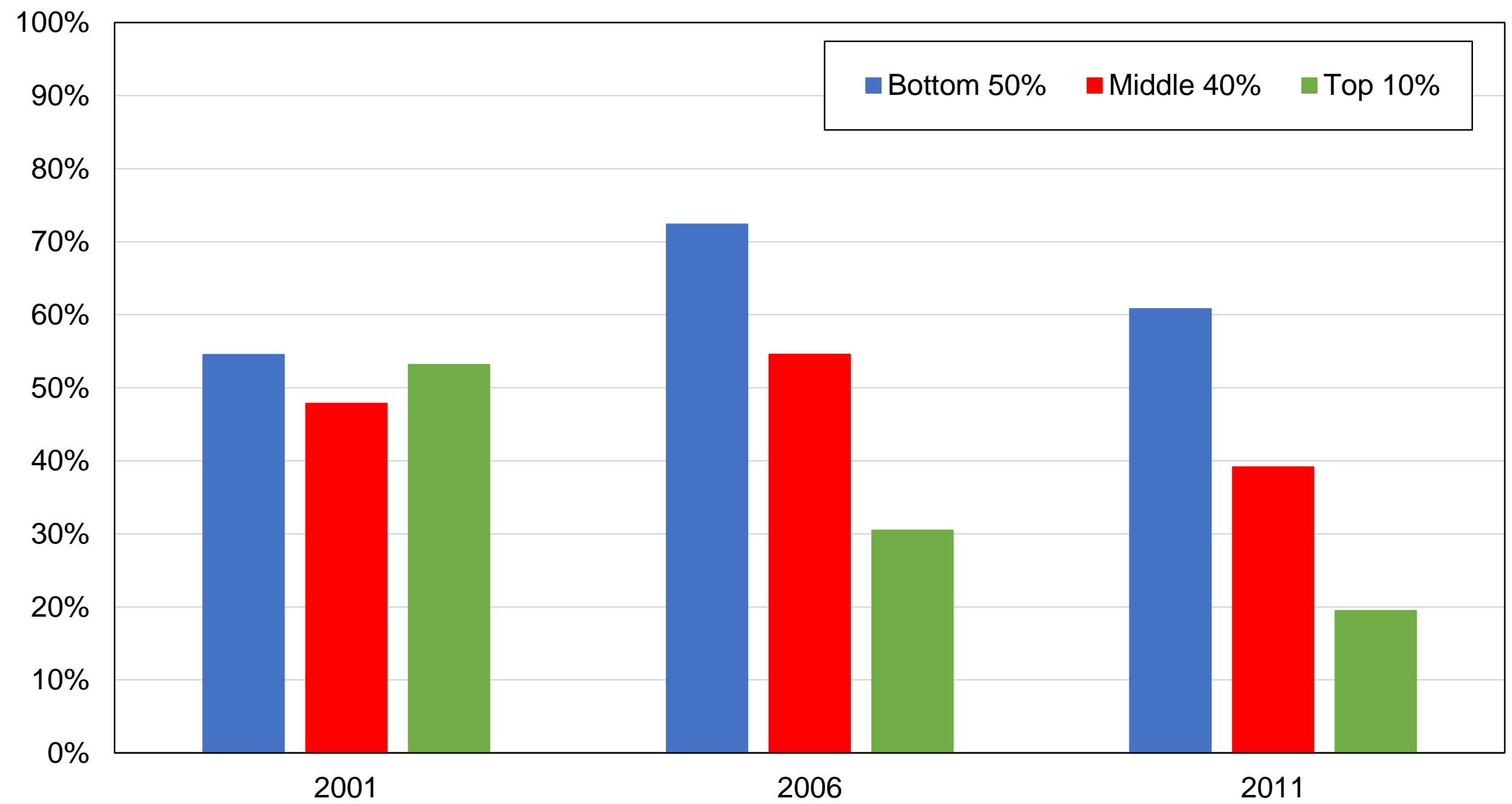

Source: authors' computations using Thai political attitudes surveys.

Note: the figure shows the share of votes received by Thai Rak Thai / Pheu Thai / Other pro-Thaksin parties by education group. 
Figure AB3 - Vote for TRT / PT / Other pro-Thaksin by income quintile

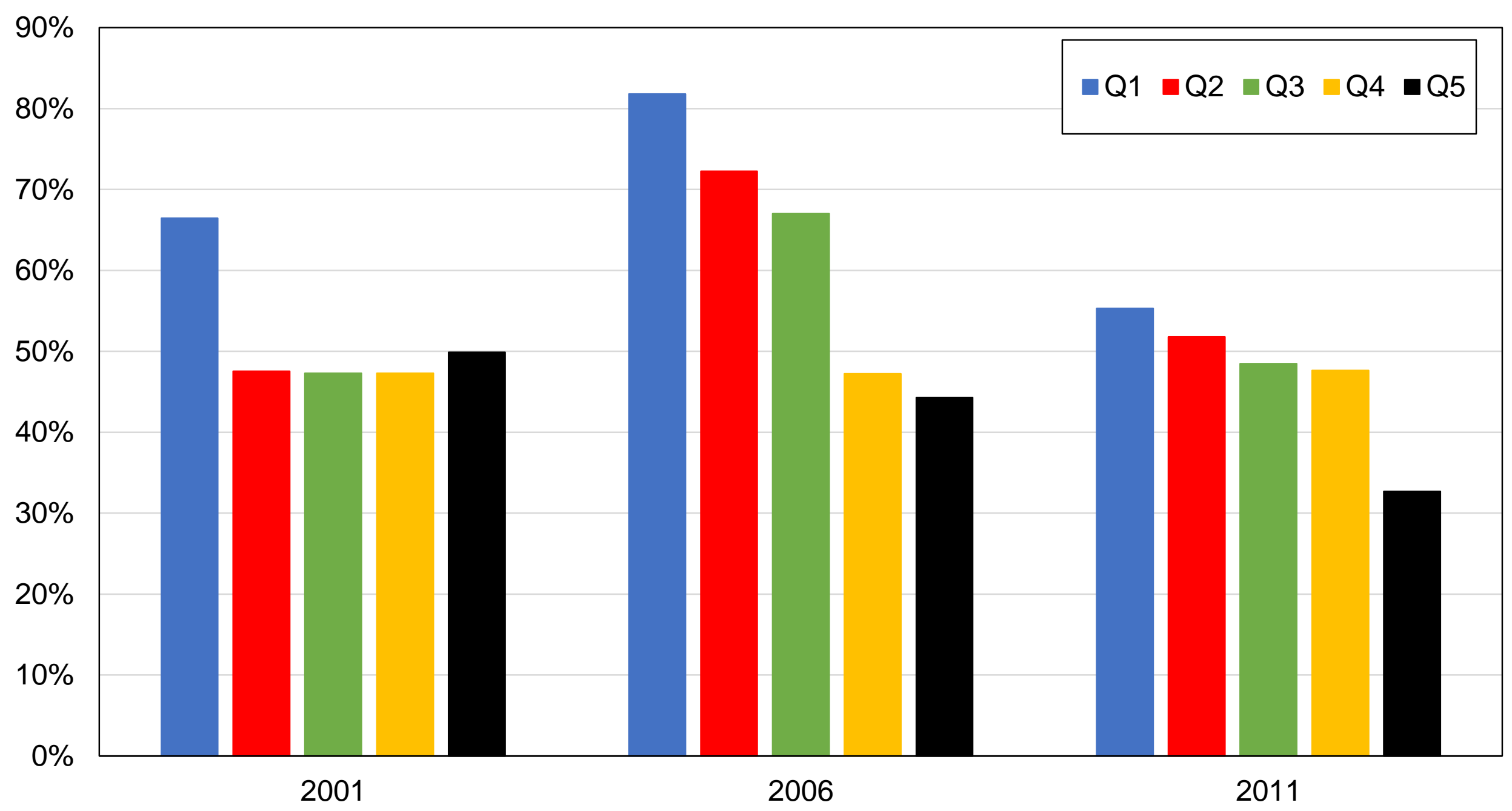

Source: authors' computations using Thai political attitudes surveys.

Note: the figure shows the share of votes received by Thai Rak Thai / Pheu Thai / Other pro-Thaksin parties by income quintile. 
Figure AB4 - Vote for TRT / PT / Other pro-Thaksin by income group

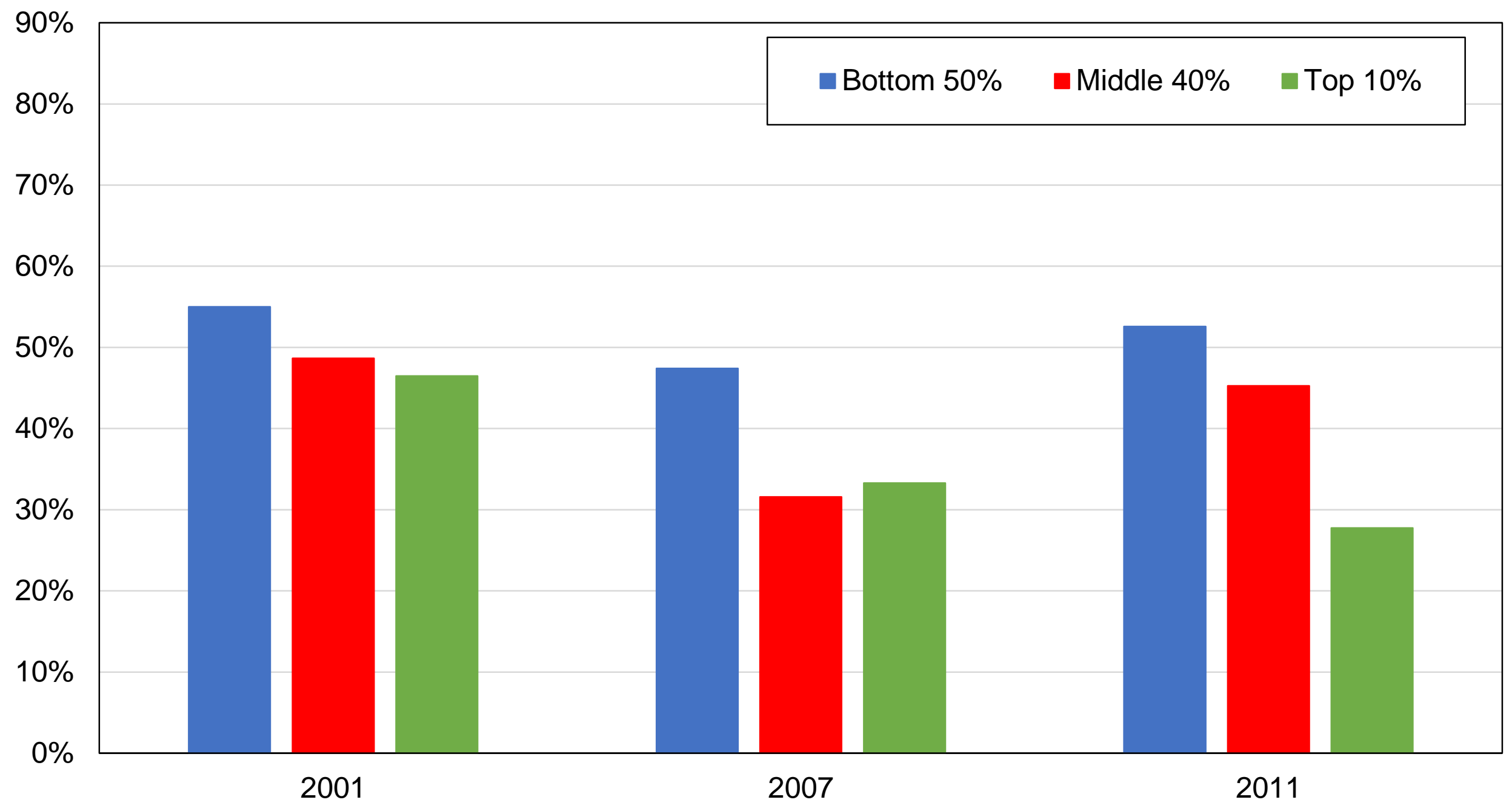

Source: authors' computations using Thai political attitudes surveys.

Note: the figure shows the share of votes received by Thai Rak Thai / Pheu Thai / Other pro-Thaksin parties by income group. 
Figure AB5 - Vote for TRT / PT / Other pro-Thaksin by wealth quintile

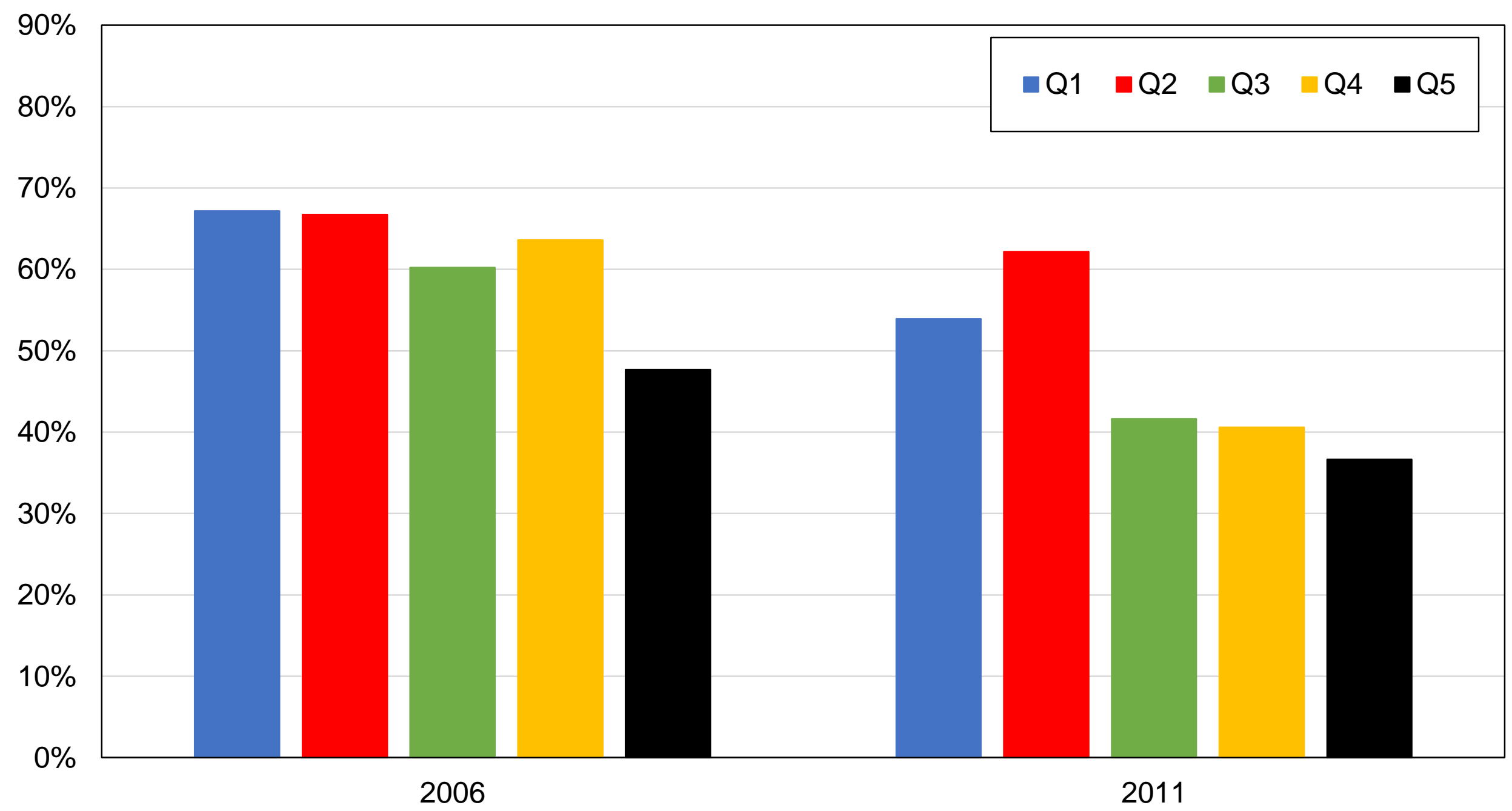

Source: authors' computations using Thai political attitudes surveys.

Note: the figure shows the share of votes received by Thai Rak Thai / Pheu Thai / Other pro-Thaksin parties by wealth quintile. 
Figure AB6 - Vote for TRT / PT / Other pro-Thaksin by wealth group

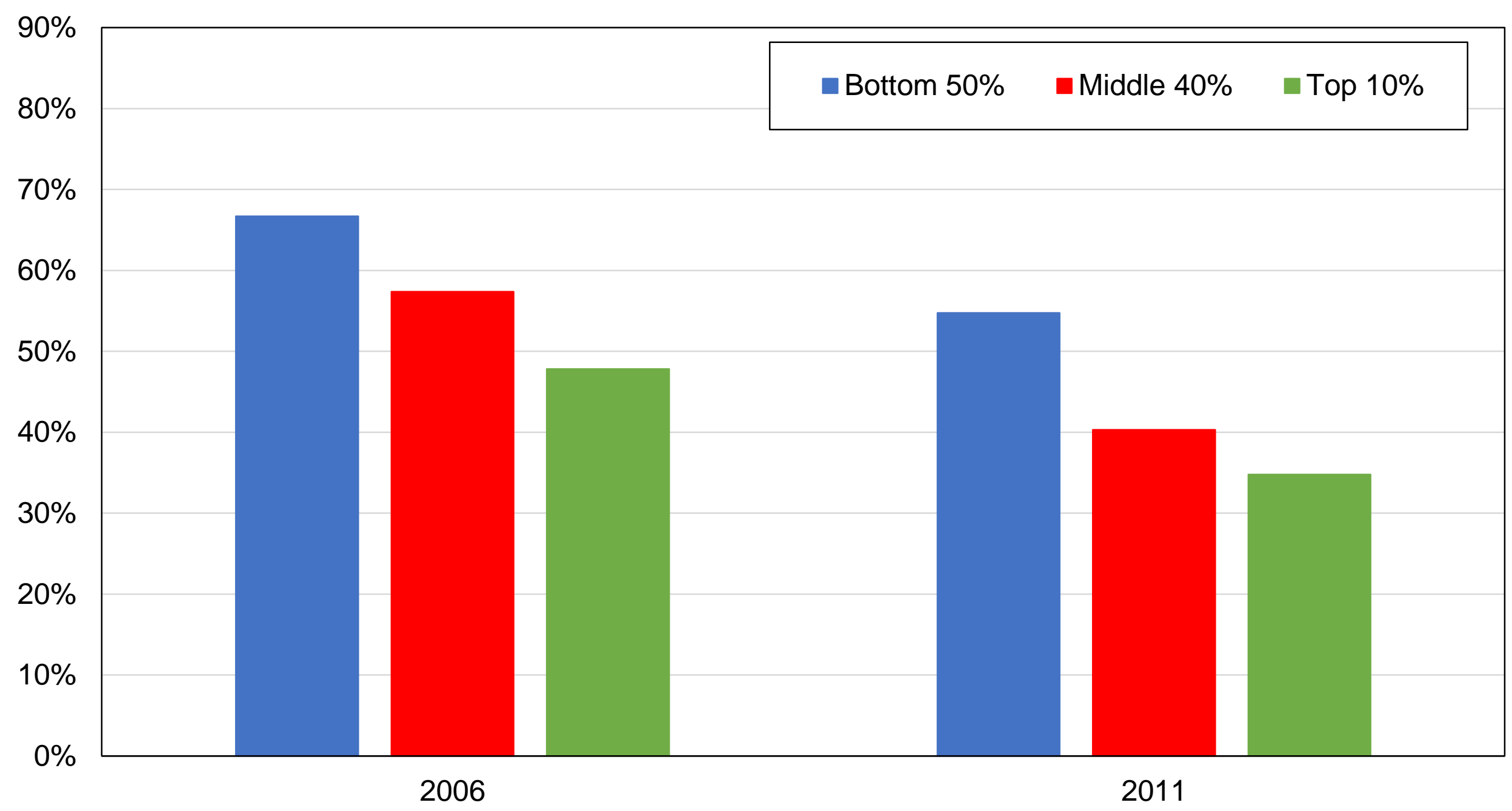

Source: authors' computations using Thai political attitudes surveys.

Note: the figure shows the share of votes received by Thai Rak Thai / Pheu Thai / Other pro-Thaksin parties by wealth group. 
Figure AB7 - Vote for TRT / PT / Other pro-Thaksin by location

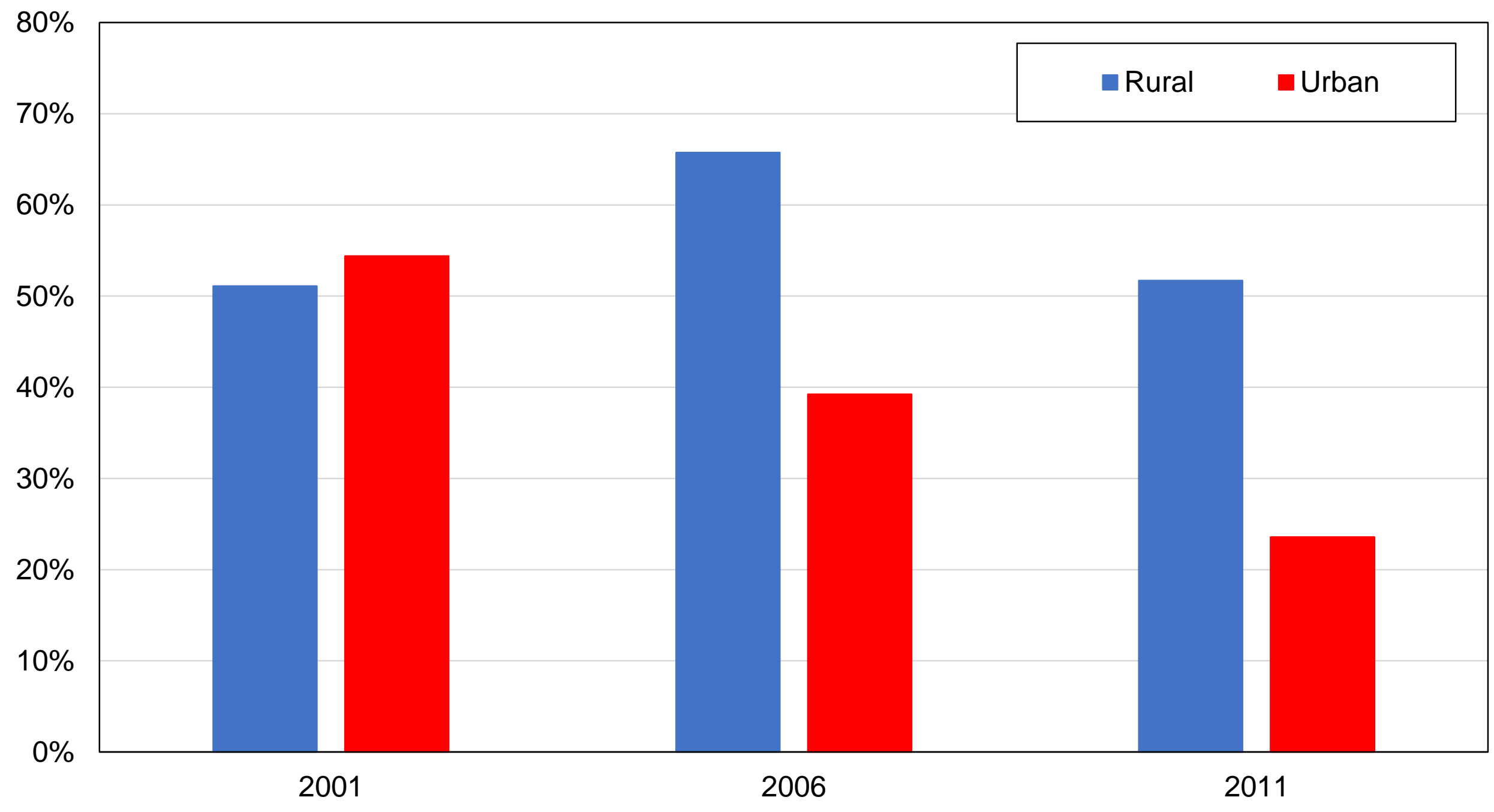

Source: authors' computations using Thai political attitudes surveys.

Note: the figure shows the share of votes received by Thai Rak Thai / Pheu Thai / Other pro-Thaksin parties by location. 
Figure AB8 - Vote for TRT / PT / Other pro-Thaksin by region, 2011

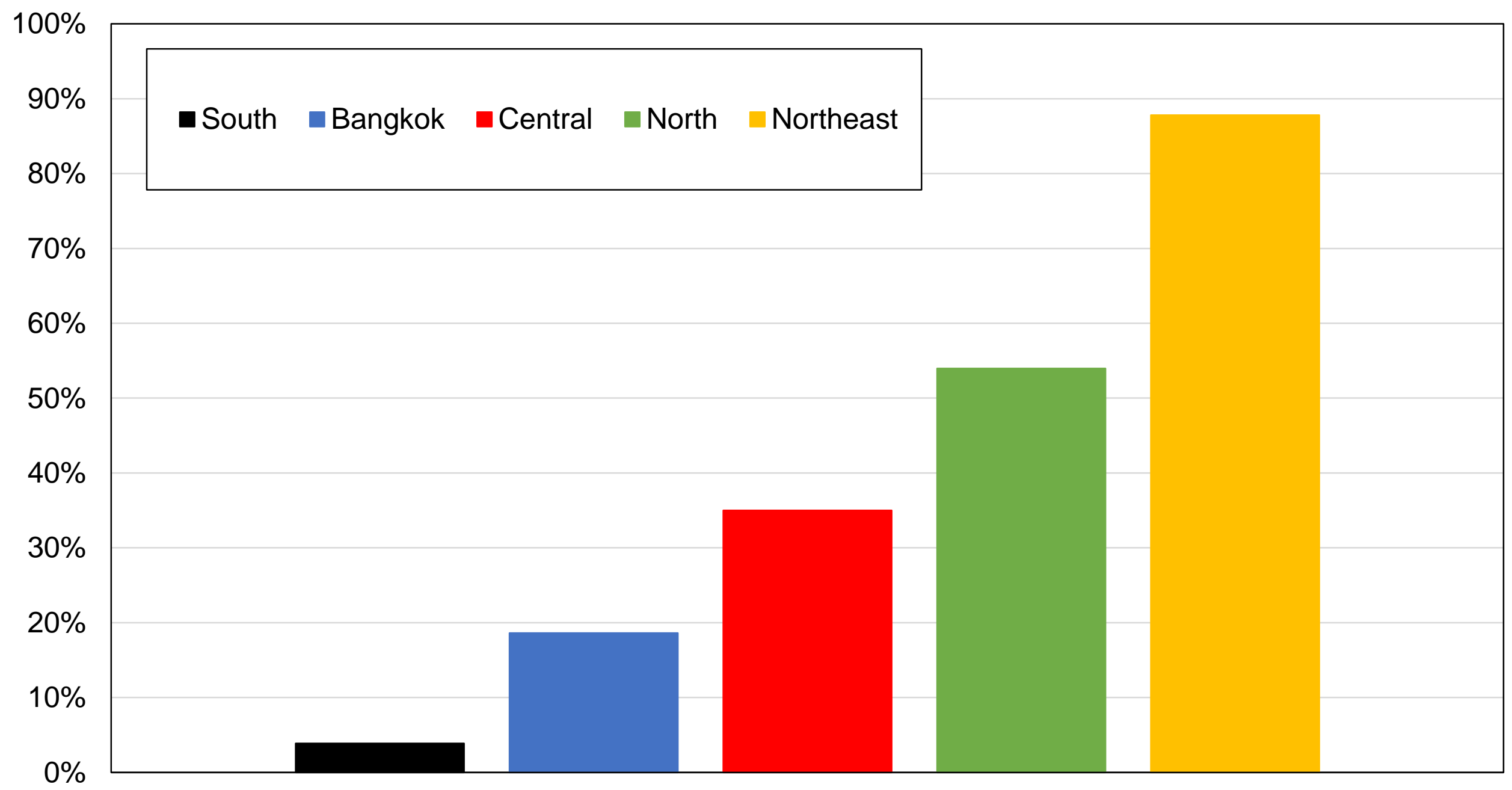

Source: authors' computations using Thai political attitudes surveys.

Note: the figure shows the share of votes received by Thai Rak Thai / Pheu Thai / Other pro-Thaksin parties by region. 
Figure AB9 - Vote for TRT / PT / Other pro-Thaksin by age group

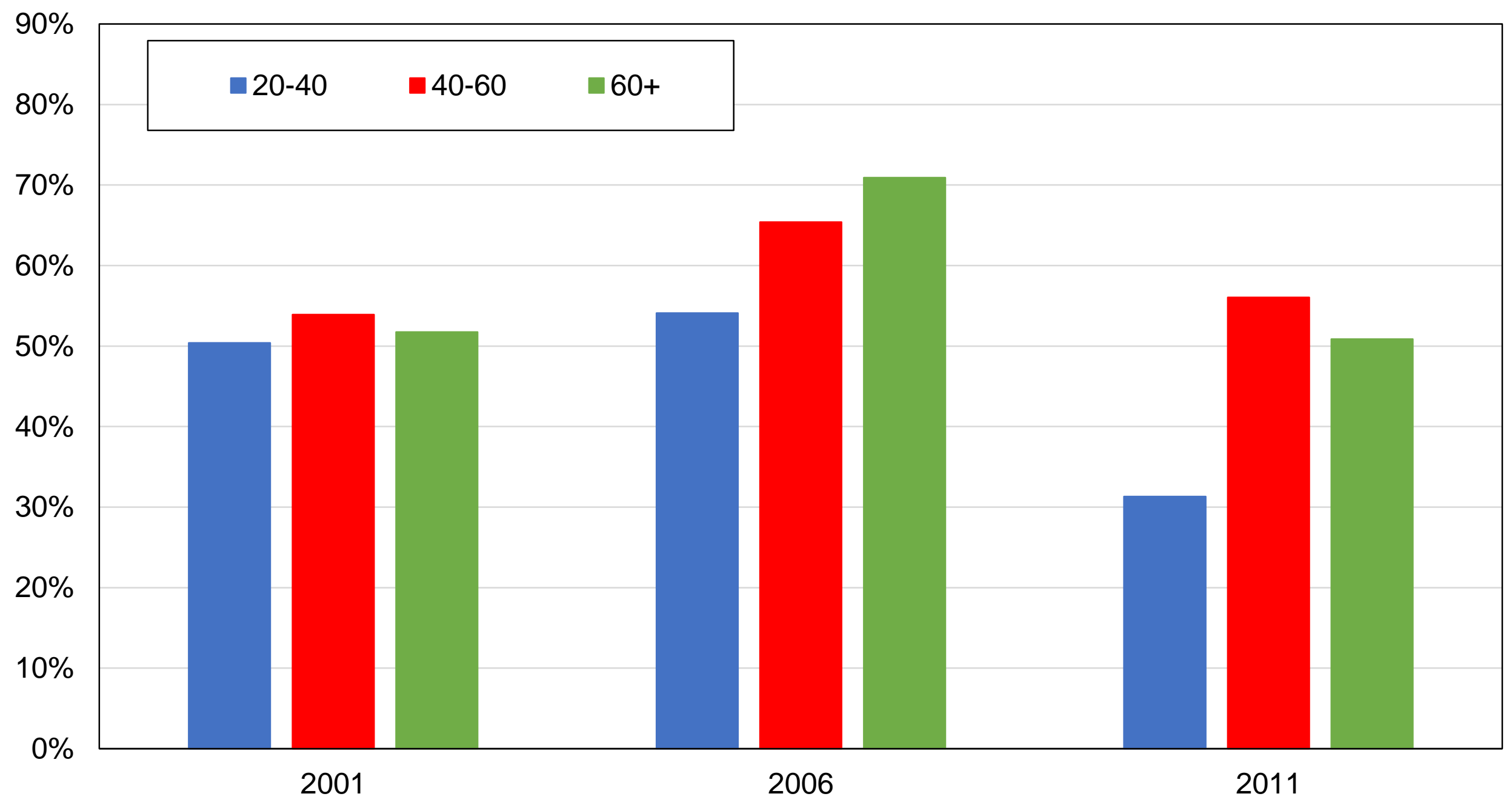

Source: authors' computations using Thai political attitudes surveys.

Note: the figure shows the share of votes received by Thai Rak Thai / Pheu Thai / Other pro-Thaksin parties by age group. 
Figure AB10 - Vote for TRT / PT / Other pro-Thaksin by gender

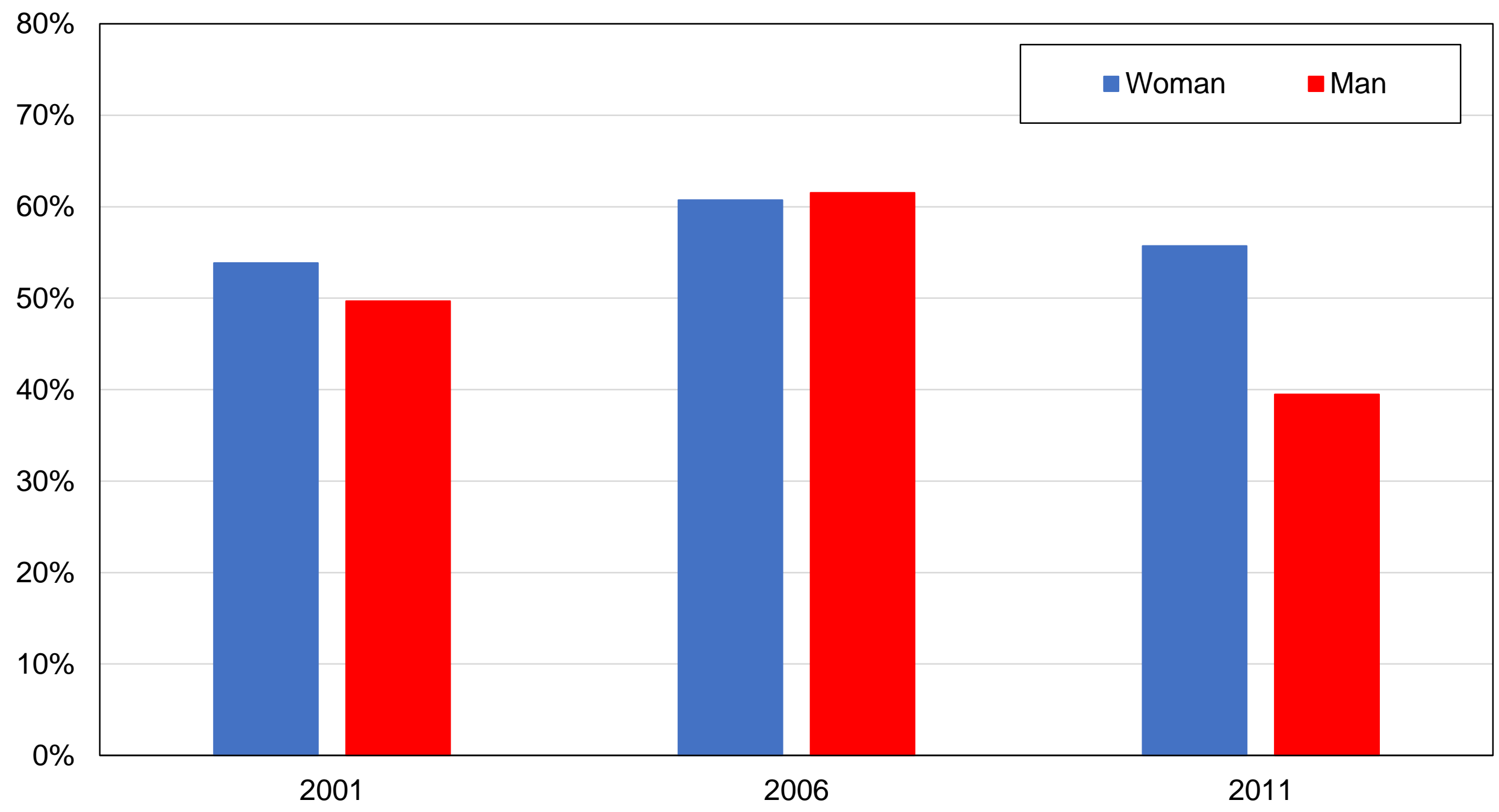

Source: authors' computations using Thai political attitudes surveys.

Note: the figure shows the share of votes received by Thai Rak Thai / Pheu Thai / Other pro-Thaksin parties by gender. 
Figure AB11 - Vote for TRT / PT / Other pro-Thaksin by religion

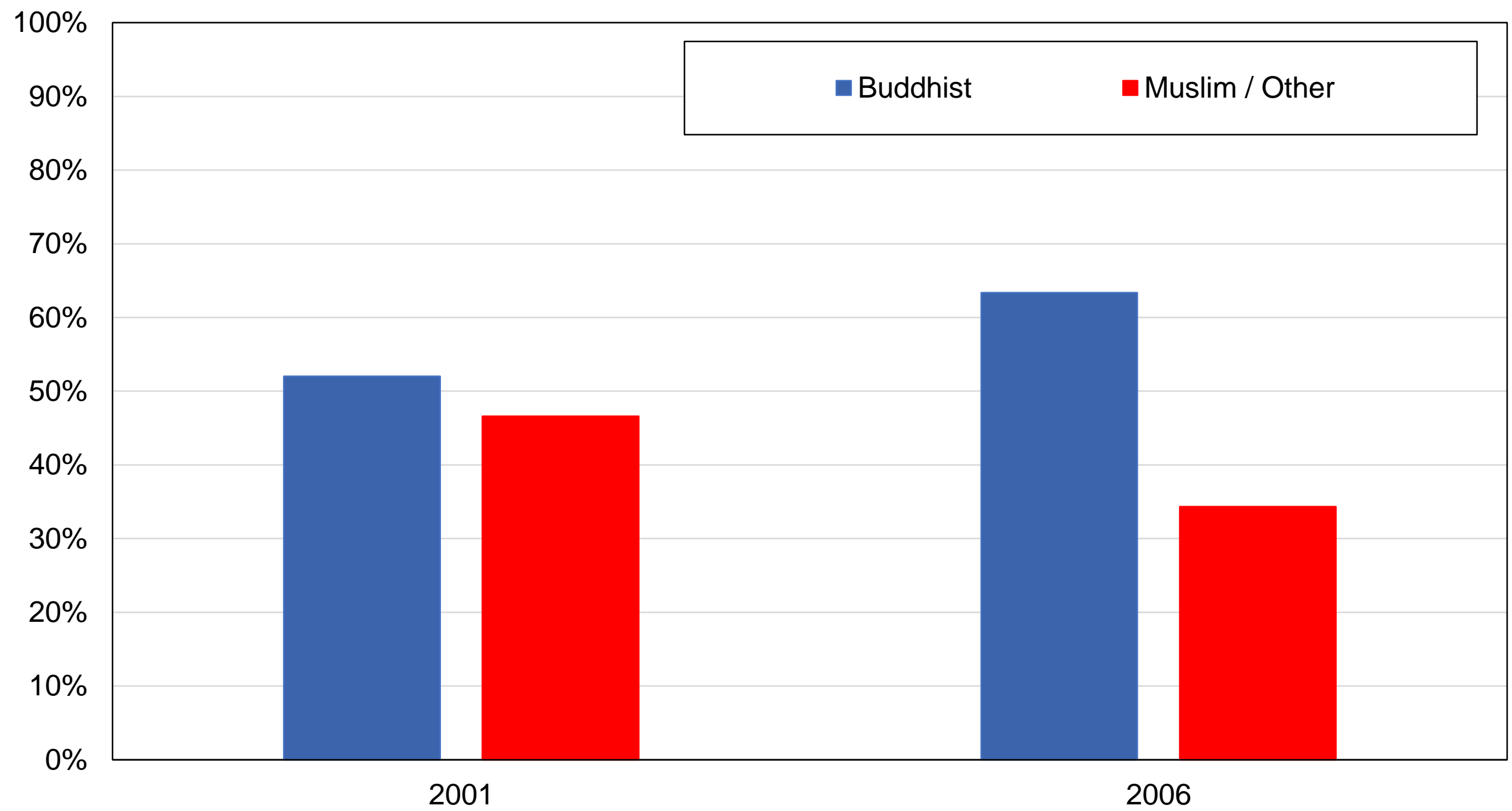

Source: authors' computations using Thai political attitudes surveys.

Note: the figure shows the share of votes received by Thai Rak Thai / Pheu Thai / Other pro-Thaksin parties by religious affiliation. 2011 is excluded due to too low sample sizes. 
Figure AB12 - Vote for TRT / PT / Other pro-Thaksin by employment status

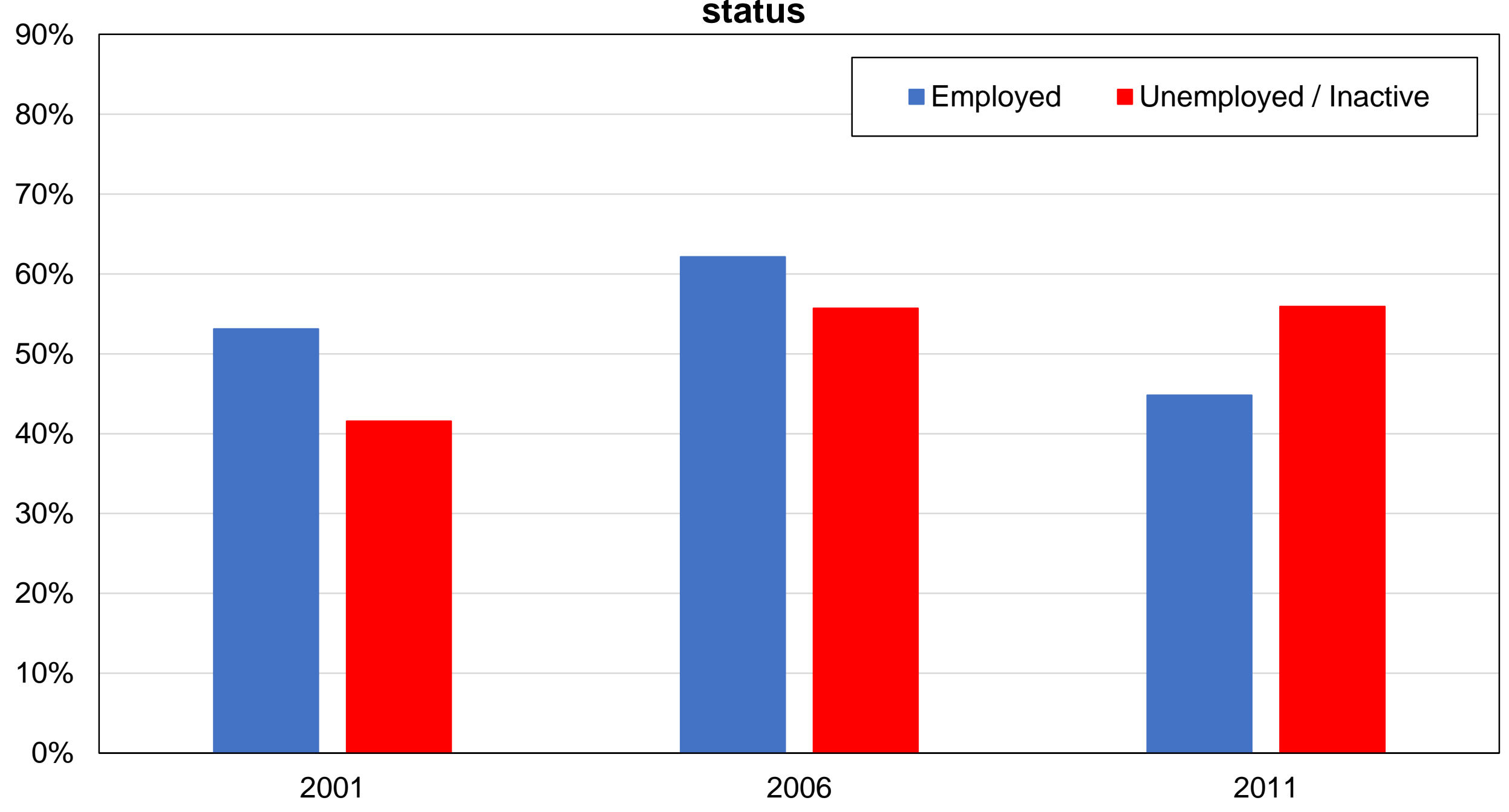

Source: authors' computations using Thai political attitudes surveys.

Note: the figure shows the share of votes received by Thai Rak Thai / Pheu Thai / Other pro-Thaksin parties by employment status. 


\section{Figure AC1 - Vote for TRT / PT / Other pro-Thaksin among top-income}

and highest-educated voters

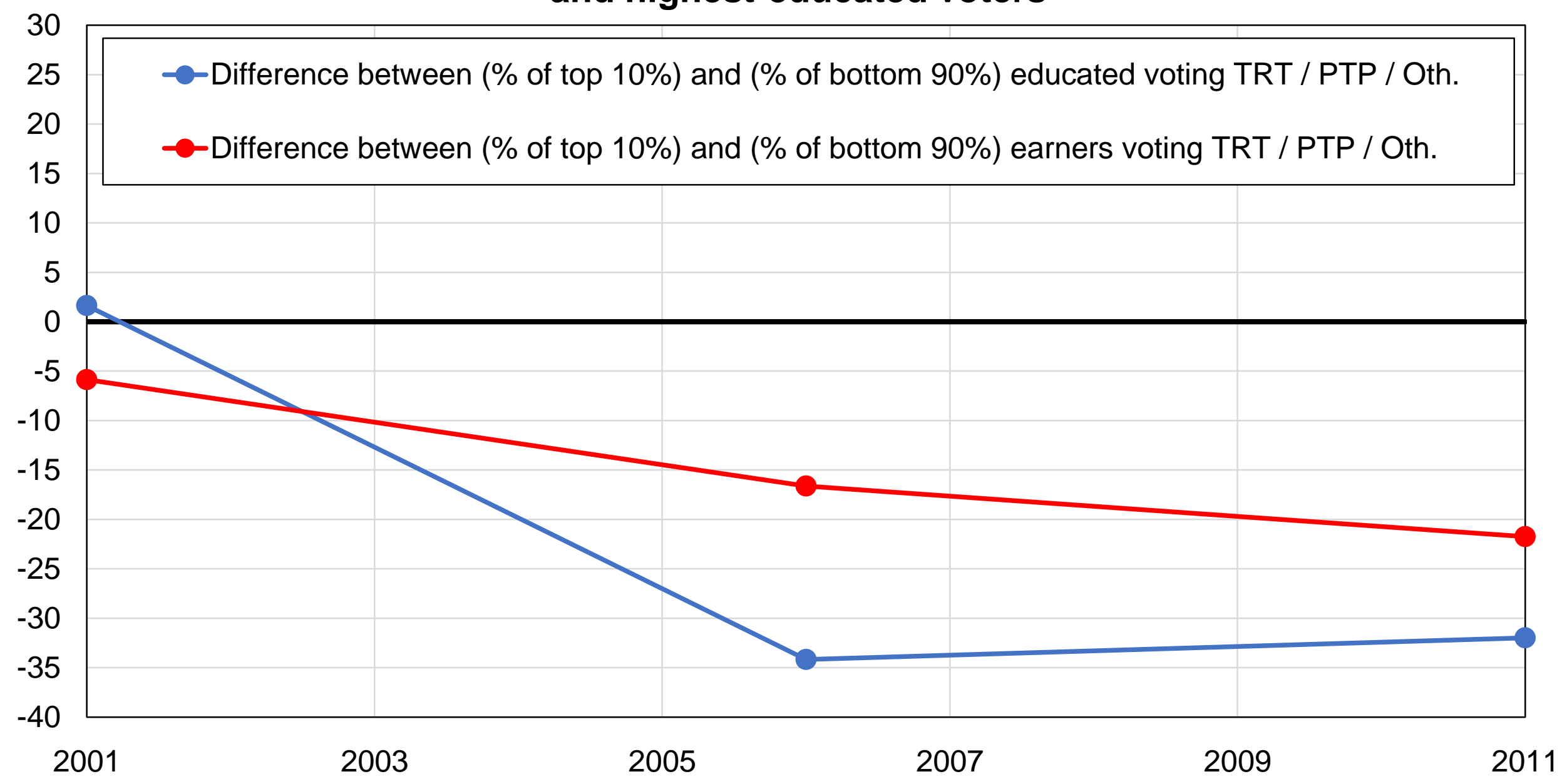

Source: authors' computations using Thai political attitudes surveys.

Note: the figure shows the difference between the share of top $10 \%$ educated voters and the share of bottom $90 \%$ educated voters voting for Thai Rak Thai / Pheu Thai / Other pro-Thaksin parties, and the same difference between top $10 \%$ earners and bottom $90 \%$ earners. 


\section{Figure AC2 - Vote for TRT / PT / Other pro-Thaksin among top-income}

and highest-educated voters, after controls

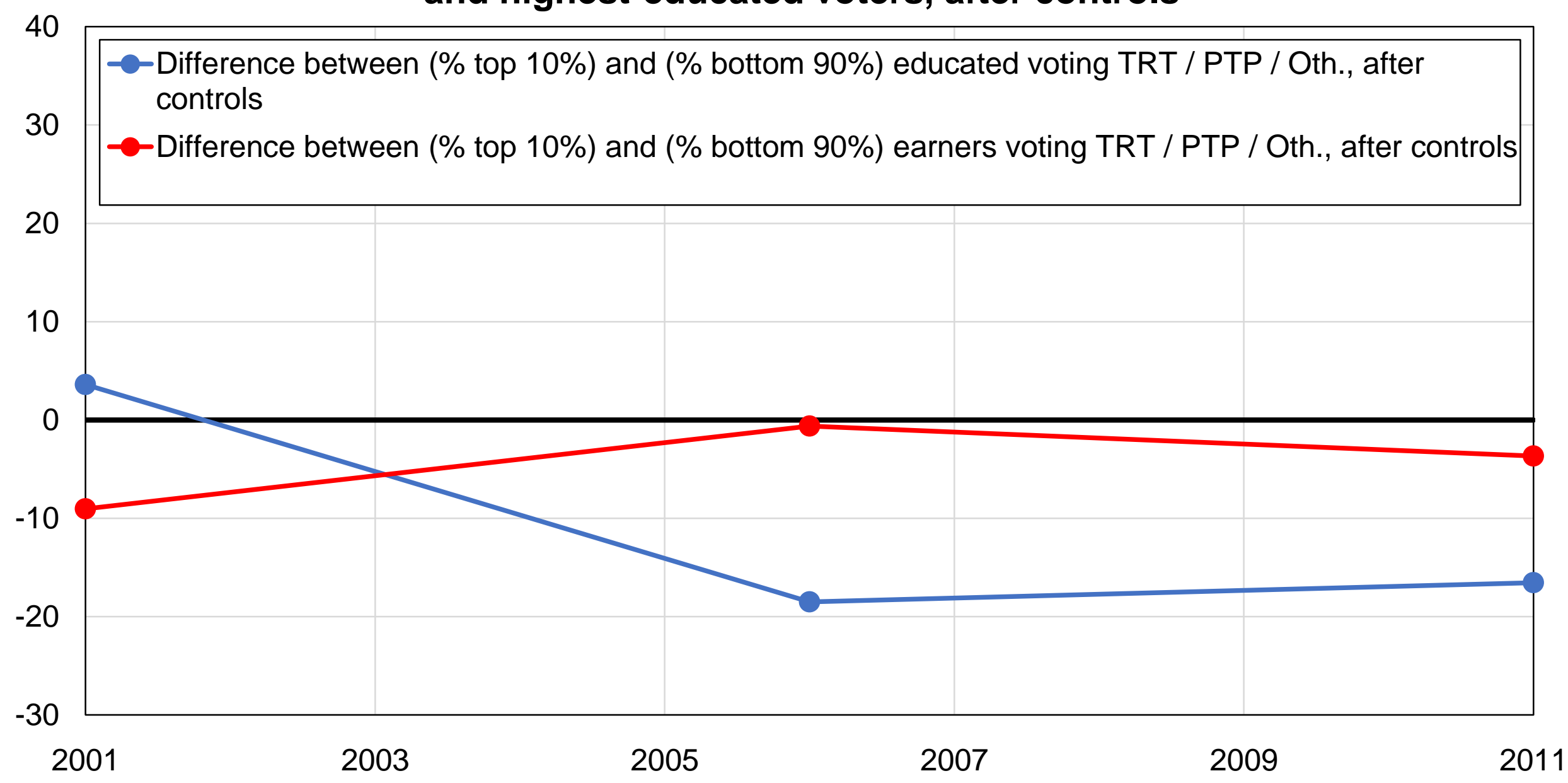

Source: authors' computations using Thai political attitudes surveys.

Note: the figure shows the difference between the share of top $10 \%$ educated voters and the share of bottom 90\% educated voters voting for Thai Rak Thai / Pheu Thai / Other pro-Thaksin parties, and the same difference between top $10 \%$ earners and bottom $90 \%$ earners, after controls. 


\section{Figure AC3 - Vote for TRT / PT / Other pro-Thaksin among}

highest-educated voters

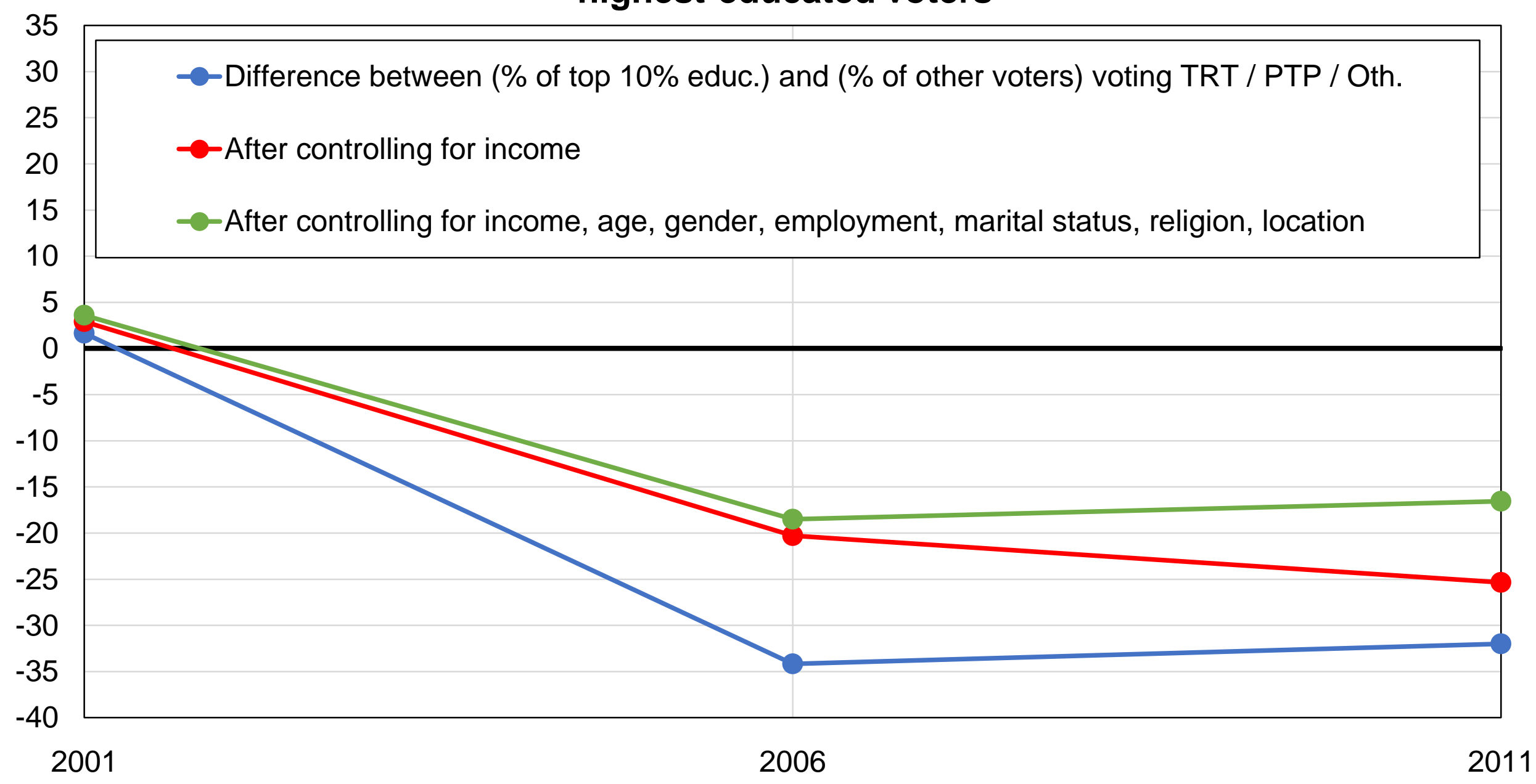

Source: authors' computations using Thai political attitudes surveys.

Note: the figure shows the difference between the share of top $10 \%$ educated voters and the share of other voters voting for Thai Rak Thai / Pheu Thai / Other pro-Thaksin parties, before and after controlling for other variables. 


\section{Figure AC4 - Vote for TRT / PT / Other pro-Thaksin among university graduates}

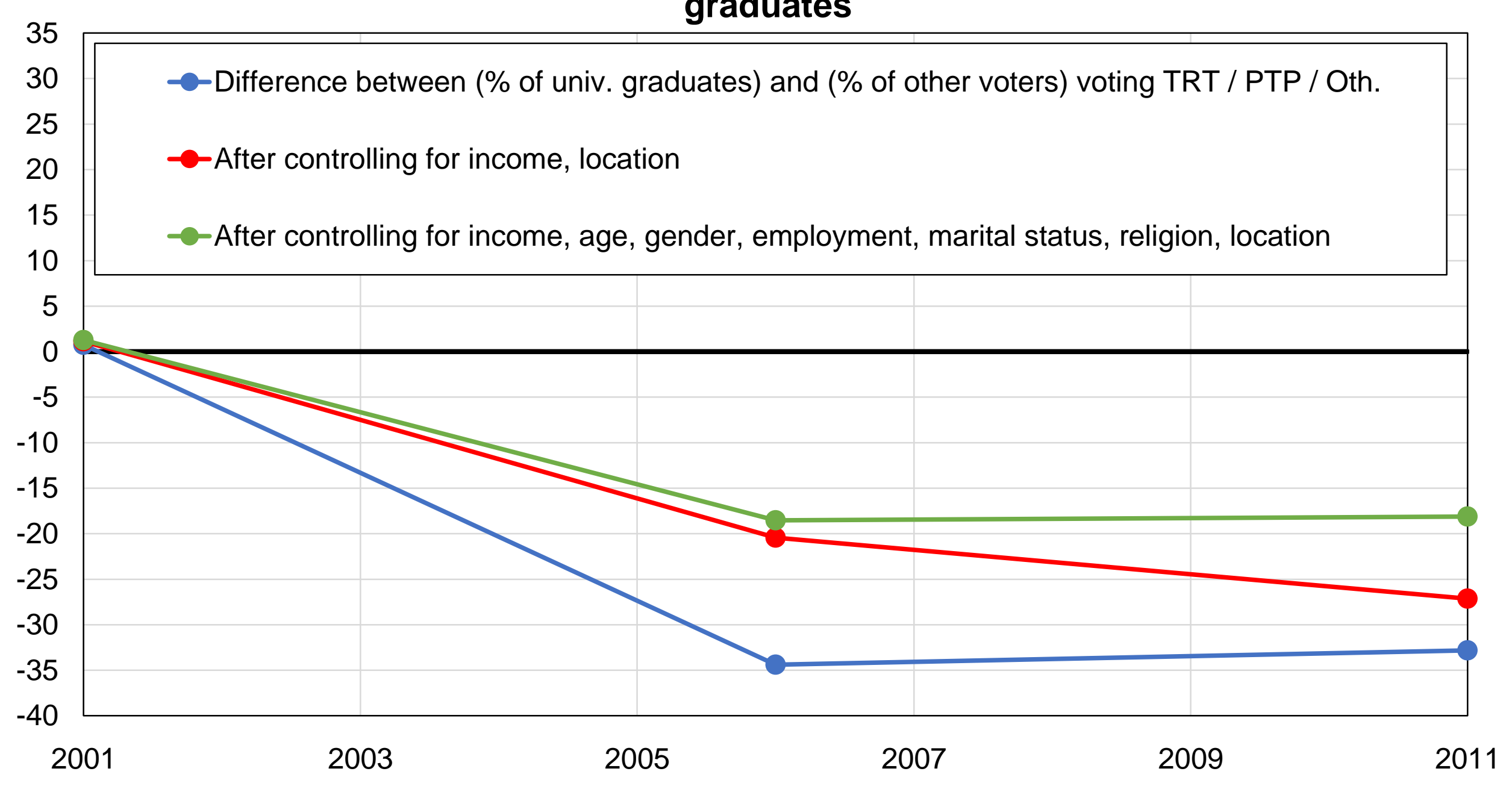

Source: authors' computations using Thai political attitudes surveys.

Note: the figure shows the difference between the share of university graduates and the share of other voters voting for Thai Rak Thai / Pheu Thai / Other pro-Thaksin parties, before and after controlling for other variables. 


\section{Figure AC5 - Vote for TRT / PT / Other pro-Thaksin among bottom 50\%}

earners

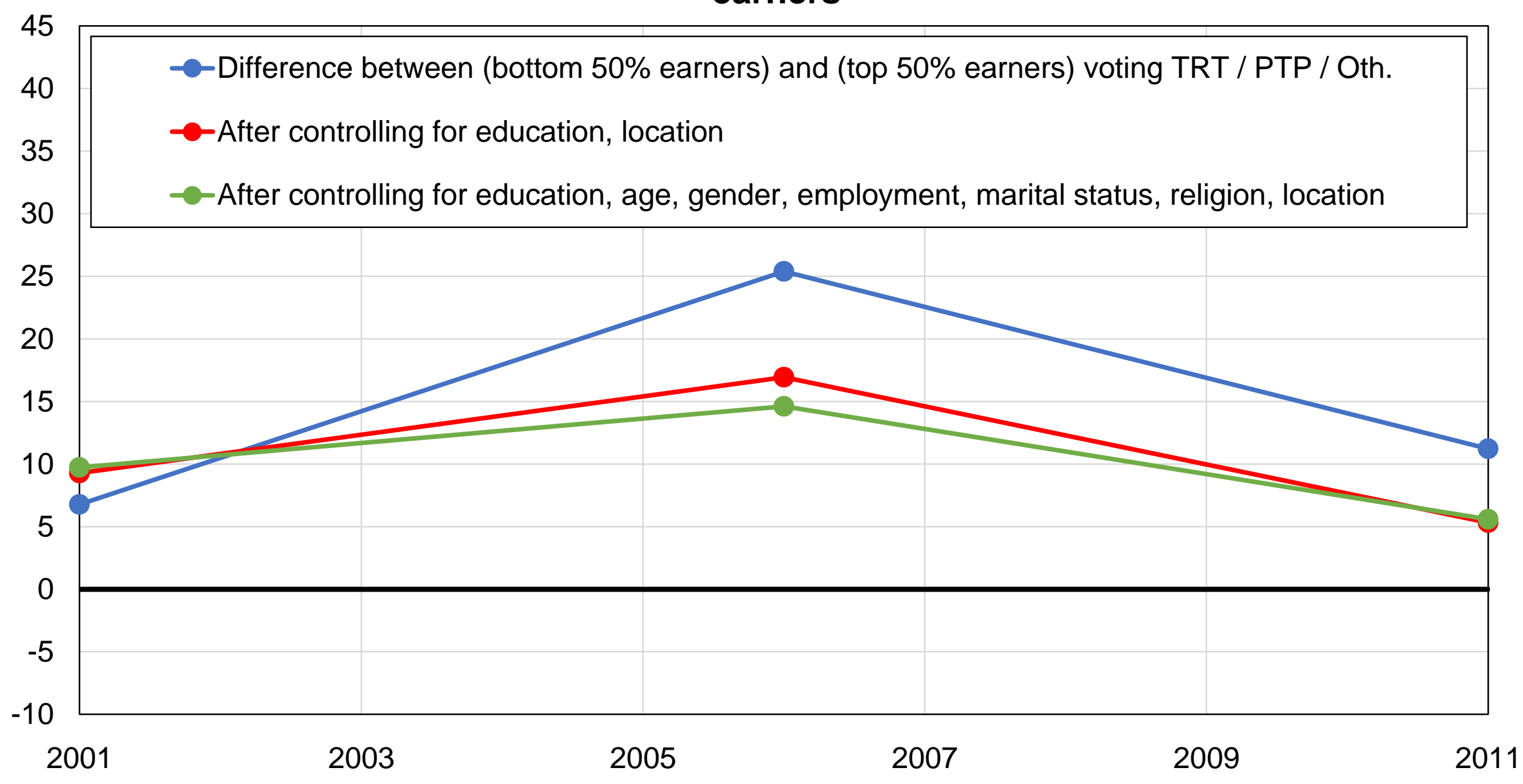

Source: authors' computations using Thai political attitudes surveys.

Note: the figure shows the difference between the share of bottom $50 \%$ earners and the share of other voters voting for Thai Rak Thai / Pheu Thai / Other pro-Thaksin parties, before and after controlling for other variables. 
Figure AC6 - Vote for TRT / PT / Other pro-Thaksin among top 10\% earners

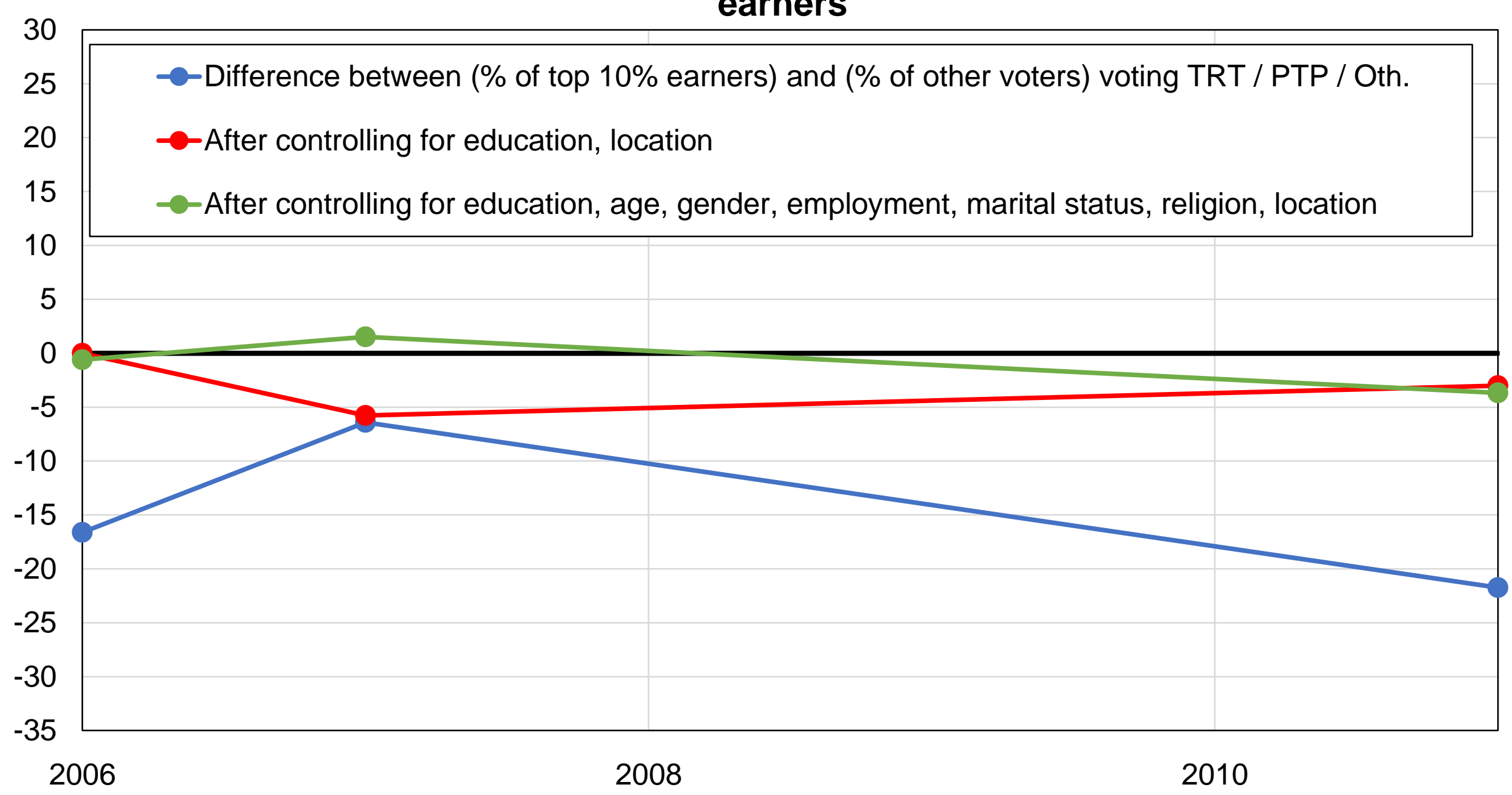

Source: authors' computations using Thai political attitudes surveys.

Note: the figure shows the difference between the share of top $10 \%$ earners and the share of other voters voting for Thai Rak Thai / Pheu Thai / Other pro-Thaksin parties, before and after controlling for other variables. 


\section{Figure AC7 - Vote for TRT / PT / Other pro-Thaksin among women}

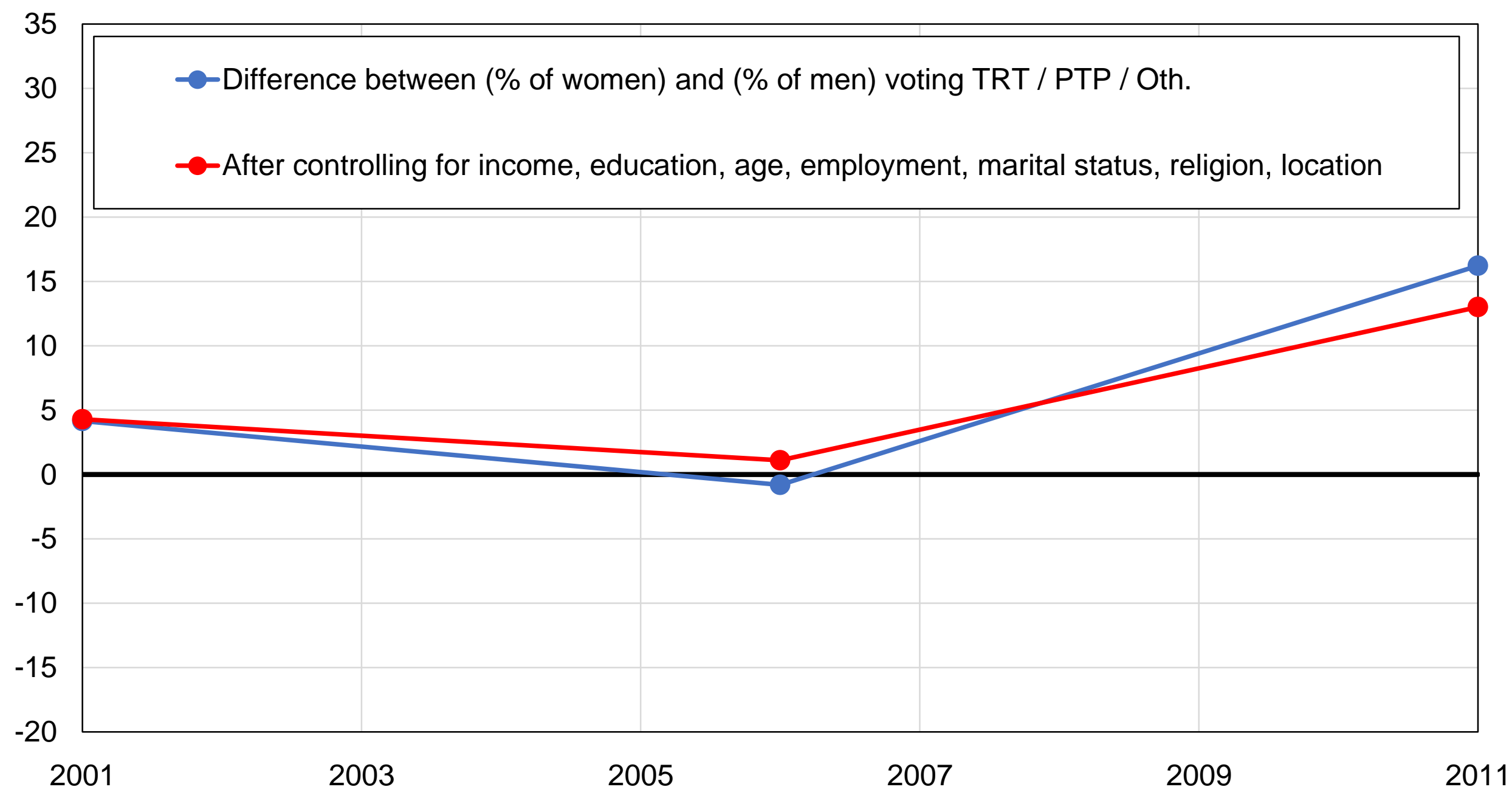

Source: authors' computations using Thai political attitudes surveys.

Note: the figure shows the difference between the share of women and the share of men voting for Thai Rak Thai / Pheu Thai / Other pro-Thaksin parties, before and after controlling for other variables. 


\begin{tabular}{|clcc|}
\hline \multicolumn{4}{|c|}{ Table AA1 - Survey data sources } \\
\hline Year & \multicolumn{1}{|c|}{ Survey } & Source & Sample size \\
\hline 2001 & Asian Barometers & AB & 1546 \\
2006 & Asian Barometers & AB & 1546 \\
2007 & Asian Barometers & AB & 1512 \\
2011 & Asian Barometers & AB & 1200 \\
\hline Source: authors' elaboration. & \\
Note: the table shows the surveys used, the source from which these surveys can \\
be obtained, and the sample size of each survey. AB: Asian Barometers. \\
\hline
\end{tabular}




\begin{tabular}{|c|c|c|c|c|}
\hline \multicolumn{5}{|c|}{ Table AA2 - Composition of the electorate } \\
\hline & 2001 & 2006 & 2007 & 2011 \\
\hline Education: Primary & $83 \%$ & $71 \%$ & $75 \%$ & $71 \%$ \\
\hline Education: Secondary & $9 \%$ & $19 \%$ & $18 \%$ & $16 \%$ \\
\hline Education: Tertiary & $9 \%$ & $9 \%$ & $7 \%$ & $13 \%$ \\
\hline Age: $20-40$ & $53 \%$ & $45 \%$ & $30 \%$ & $33 \%$ \\
\hline Age: $40-60$ & $33 \%$ & $41 \%$ & $52 \%$ & $52 \%$ \\
\hline Age: $60+$ & $14 \%$ & $14 \%$ & $18 \%$ & $14 \%$ \\
\hline Gender: Man & $49 \%$ & $48 \%$ & $48 \%$ & $48 \%$ \\
\hline Employment status: Employed & $85 \%$ & $85 \%$ & $75 \%$ & $89 \%$ \\
\hline Employment status: Unemployed & $0 \%$ & $4 \%$ & $6 \%$ & $1 \%$ \\
\hline Employment status: Inactive & $15 \%$ & $12 \%$ & $19 \%$ & $10 \%$ \\
\hline Marital status: Married / Partner & $72 \%$ & $71 \%$ & $80 \%$ & $73 \%$ \\
\hline Religion: Buddhist & $94 \%$ & $93 \%$ & $96 \%$ & $99 \%$ \\
\hline Religion: Muslim / Other & $6 \%$ & $7 \%$ & $4 \%$ & $1 \%$ \\
\hline Location: Rural areas & $74 \%$ & $80 \%$ & $87 \%$ & $80 \%$ \\
\hline Region: Bangkok & & & & $8 \%$ \\
\hline Region: Central & & & & $25 \%$ \\
\hline Region: North & & & & $20 \%$ \\
\hline Region: Northeast & & & & $34 \%$ \\
\hline Region: South & & & & $13 \%$ \\
\hline \multicolumn{5}{|c|}{$\begin{array}{l}\text { Source: authors' computations using Thai political attitudes surveys. } \\
\text { Note: the table shows descriptive statistics by year for selected available variables. }\end{array}$} \\
\hline
\end{tabular}


Table AA3 - Regional inequality in Thailand

\begin{tabular}{|l|l|l|l|}
\hline & Gini of spatial inequality & \multicolumn{2}{|c|}{ GPP per capita (\% of national average) } \\
\hline & US & Europe & \\
1929 & $20 \%$ & & \\
1930 & $21 \%$ & & \\
1931 & $21 \%$ & & \\
1932 & $22 \%$ & & \\
1933 & $21 \%$ & & \\
1934 & $19 \%$ & & \\
1935 & $18 \%$ & & \\
1936 & $18 \%$ & & \\
1937 & $17 \%$ & & \\
1938 & $17 \%$ & & \\
1939 & $17 \%$ & & \\
1940 & $18 \%$ & & \\
1941 & $16 \%$ & & \\
1942 & $15 \%$ & & \\
1943 & $14 \%$ & & \\
1944 & $13 \%$ & & \\
1945 & $12 \%$ & & \\
1946 & $12 \%$ & & \\
1947 & $12 \%$ & & \\
1948 & $11 \%$ & & \\
1949 & $11 \%$ & & \\
1950 & $11 \%$ & $29 \%$ & \\
1951 & $11 \%$ & $30 \%$ & \\
1952 & $10 \%$ & $29 \%$ & \\
1953 & $11 \%$ & $30 \%$ & \\
1954 & $10 \%$ & $30 \%$ & \\
1955 & $10 \%$ & $29 \%$ & \\
1956 & $10 \%$ & $30 \%$ & \\
1957 & $10 \%$ & $30 \%$ & \\
1958 & $9 \%$ & $29 \%$ &
\end{tabular}




\begin{tabular}{|c|c|c|}
\hline 1959 & $9 \%$ & $30 \%$ \\
\hline 1960 & $9 \%$ & $29 \%$ \\
\hline 1961 & $9 \%$ & $29 \%$ \\
\hline 1962 & $9 \%$ & $29 \%$ \\
\hline 1963 & $9 \%$ & $28 \%$ \\
\hline 1964 & $9 \%$ & $29 \%$ \\
\hline 1965 & $8 \%$ & $28 \%$ \\
\hline 1966 & $8 \%$ & $28 \%$ \\
\hline 1967 & $8 \%$ & $27 \%$ \\
\hline 1968 & $8 \%$ & $27 \%$ \\
\hline 1969 & $8 \%$ & $27 \%$ \\
\hline 1970 & $7 \%$ & $28 \%$ \\
\hline 1971 & $7 \%$ & $28 \%$ \\
\hline 1972 & $6 \%$ & $27 \%$ \\
\hline 1973 & $6 \%$ & $28 \%$ \\
\hline 1974 & $6 \%$ & $27 \%$ \\
\hline 1975 & $6 \%$ & $27 \%$ \\
\hline 1976 & $6 \%$ & $27 \%$ \\
\hline 1977 & $7 \%$ & $26 \%$ \\
\hline 1978 & $7 \%$ & $26 \%$ \\
\hline 1979 & $7 \%$ & $26 \%$ \\
\hline 1980 & $8 \%$ & $27 \%$ \\
\hline 1981 & $9 \%$ & $27 \%$ \\
\hline 1982 & $9 \%$ & $27 \%$ \\
\hline 1983 & $8 \%$ & $27 \%$ \\
\hline 1984 & $8 \%$ & $27 \%$ \\
\hline 1985 & $8 \%$ & $27 \%$ \\
\hline 1986 & $8 \%$ & $27 \%$ \\
\hline 1987 & $8 \%$ & $26 \%$ \\
\hline 1988 & $8 \%$ & $26 \%$ \\
\hline 1989 & $8 \%$ & $26 \%$ \\
\hline 1990 & $8 \%$ & $27 \%$ \\
\hline 1991 & $7 \%$ & $26 \%$ \\
\hline 1992 & $7 \%$ & $27 \%$ \\
\hline
\end{tabular}

\begin{tabular}{|c|c|}
\hline $40 \%$ & \\
\hline $39 \%$ & \\
\hline $38 \%$ & \\
\hline $40 \%$ & \\
\hline $40 \%$ & \\
\hline $38 \%$ & \\
\hline $41 \%$ & \\
\hline $41 \%$ & \\
\hline $41 \%$ & \\
\hline $41 \%$ & \\
\hline $44 \%$ & \\
\hline $45 \%$ & \\
\hline $45 \%$ & \\
\hline $45 \%$ & \\
\hline $44 \%$ & \\
\hline $46 \%$ & \\
\hline $49 \%$ & \\
\hline $48 \%$ & \\
\hline $49 \%$ & \\
\hline $49 \%$ & \\
\hline $50 \%$ & \\
\hline $50 \%$ & \\
\hline $49 \%$ & \\
\hline $50 \%$ & \\
\hline $50 \%$ & $33 \%$ \\
\hline $51 \%$ & $33 \%$ \\
\hline $52 \%$ & $32 \%$ \\
\hline $53 \%$ & $31 \%$ \\
\hline $53 \%$ & $31 \%$ \\
\hline $54 \%$ & $30 \%$ \\
\hline $54 \%$ & $29 \%$ \\
\hline $54 \%$ & $28 \%$ \\
\hline
\end{tabular}

\begin{tabular}{l}
$258 \%$ \\
$236 \%$ \\
$235 \%$ \\
$249 \%$ \\
$249 \%$ \\
$243 \%$ \\
$261 \%$ \\
$270 \%$ \\
$275 \%$ \\
$283 \%$ \\
$303 \%$ \\
$307 \%$ \\
$303 \%$ \\
$304 \%$ \\
$300 \%$ \\
$301 \%$ \\
$315 \%$ \\
$313 \%$ \\
$320 \%$ \\
$323 \%$ \\
$335 \%$ \\
$327 \%$ \\
$324 \%$ \\
$328 \%$ \\
$325 \%$ \\
$327 \%$ \\
$334 \%$ \\
$336 \%$ \\
$340 \%$ \\
$349 \%$ \\
$341 \%$ \\
$336 \%$ \\
\hline
\end{tabular}

\begin{tabular}{l}
$149 \%$ \\
$148 \%$ \\
$144 \%$ \\
$146 \%$ \\
$145 \%$ \\
$138 \%$ \\
$140 \%$ \\
$139 \%$ \\
$136 \%$ \\
$142 \%$ \\
$143 \%$ \\
$139 \%$ \\
$139 \%$ \\
$137 \%$ \\
$140 \%$ \\
$139 \%$ \\
$142 \%$ \\
$140 \%$ \\
$134 \%$ \\
$134 \%$ \\
$133 \%$ \\
$138 \%$ \\
$141 \%$ \\
$138 \%$ \\
$141 \%$ \\
$145 \%$ \\
$140 \%$ \\
$141 \%$ \\
$139 \%$ \\
$132 \%$ \\
$140 \%$ \\
$143 \%$ \\
\hline
\end{tabular}




\begin{tabular}{|c|c|c|c|c|c|c|c|c|}
\hline 1993 & $7 \%$ & $27 \%$ & $23 \%$ & $56 \%$ & $28 \%$ & $340 \%$ & $145 \%$ & $30 \%$ \\
\hline 1994 & $6 \%$ & $27 \%$ & $23 \%$ & $55 \%$ & $28 \%$ & $330 \%$ & $149 \%$ & $31 \%$ \\
\hline 1995 & $6 \%$ & $26 \%$ & $24 \%$ & $54 \%$ & $28 \%$ & $320 \%$ & $155 \%$ & $31 \%$ \\
\hline 1996 & $7 \%$ & $26 \%$ & $23 \%$ & $53 \%$ & $27 \%$ & $312 \%$ & $160 \%$ & $32 \%$ \\
\hline 1997 & $7 \%$ & $26 \%$ & $24 \%$ & $53 \%$ & $27 \%$ & $300 \%$ & $171 \%$ & $33 \%$ \\
\hline 1998 & $8 \%$ & $26 \%$ & $24 \%$ & $52 \%$ & $27 \%$ & $292 \%$ & $172 \%$ & $34 \%$ \\
\hline 1999 & $8 \%$ & $26 \%$ & $23 \%$ & $52 \%$ & $26 \%$ & $299 \%$ & $164 \%$ & $33 \%$ \\
\hline 2000 & $8 \%$ & $26 \%$ & $24 \%$ & $54 \%$ & $26 \%$ & $303 \%$ & $172 \%$ & $31 \%$ \\
\hline 2001 & $8 \%$ & $26 \%$ & $24 \%$ & $54 \%$ & $26 \%$ & $300 \%$ & $168 \%$ & $31 \%$ \\
\hline 2002 & $8 \%$ & $26 \%$ & $24 \%$ & $53 \%$ & $26 \%$ & $282 \%$ & $176 \%$ & $32 \%$ \\
\hline 2003 & $8 \%$ & $26 \%$ & $25 \%$ & $51 \%$ & $25 \%$ & $267 \%$ & $179 \%$ & $33 \%$ \\
\hline 2004 & $8 \%$ & $26 \%$ & $25 \%$ & $51 \%$ & $25 \%$ & $259 \%$ & $180 \%$ & $33 \%$ \\
\hline 2005 & $8 \%$ & $26 \%$ & $27 \%$ & $51 \%$ & $25 \%$ & $249 \%$ & $188 \%$ & $33 \%$ \\
\hline 2006 & $8 \%$ & $26 \%$ & $27 \%$ & $50 \%$ & $24 \%$ & $235 \%$ & $194 \%$ & $33 \%$ \\
\hline 2007 & $8 \%$ & $26 \%$ & $27 \%$ & $50 \%$ & $25 \%$ & $225 \%$ & $202 \%$ & $33 \%$ \\
\hline 2008 & $9 \%$ & $25 \%$ & $27 \%$ & $49 \%$ & $25 \%$ & $215 \%$ & $206 \%$ & $34 \%$ \\
\hline 2009 & $9 \%$ & $25 \%$ & $27 \%$ & $46 \%$ & $25 \%$ & $209 \%$ & $195 \%$ & $37 \%$ \\
\hline 2010 & $9 \%$ & $26 \%$ & $27 \%$ & $45 \%$ & $25 \%$ & $199 \%$ & $196 \%$ & $38 \%$ \\
\hline 2011 & $9 \%$ & $26 \%$ & $28 \%$ & $44 \%$ & $25 \%$ & $195 \%$ & $188 \%$ & $40 \%$ \\
\hline 2012 & $9 \%$ & $26 \%$ & $28 \%$ & $43 \%$ & & $193 \%$ & $189 \%$ & $42 \%$ \\
\hline 2013 & $9 \%$ & $26 \%$ & $28 \%$ & $43 \%$ & & $193 \%$ & $187 \%$ & $42 \%$ \\
\hline 2014 & $10 \%$ & $26 \%$ & $28 \%$ & $44 \%$ & & $199 \%$ & $184 \%$ & $41 \%$ \\
\hline 2015 & $10 \%$ & $26 \%$ & $28 \%$ & $45 \%$ & & $201 \%$ & $180 \%$ & $40 \%$ \\
\hline 2016 & $10 \%$ & $25 \%$ & $28 \%$ & $45 \%$ & & $198 \%$ & $180 \%$ & $39 \%$ \\
\hline 2017 & $10 \%$ & $25 \%$ & $28 \%$ & & & & & \\
\hline
\end{tabular}


Figure BA1 - Detailed election results in the Philippines, 1992-2016

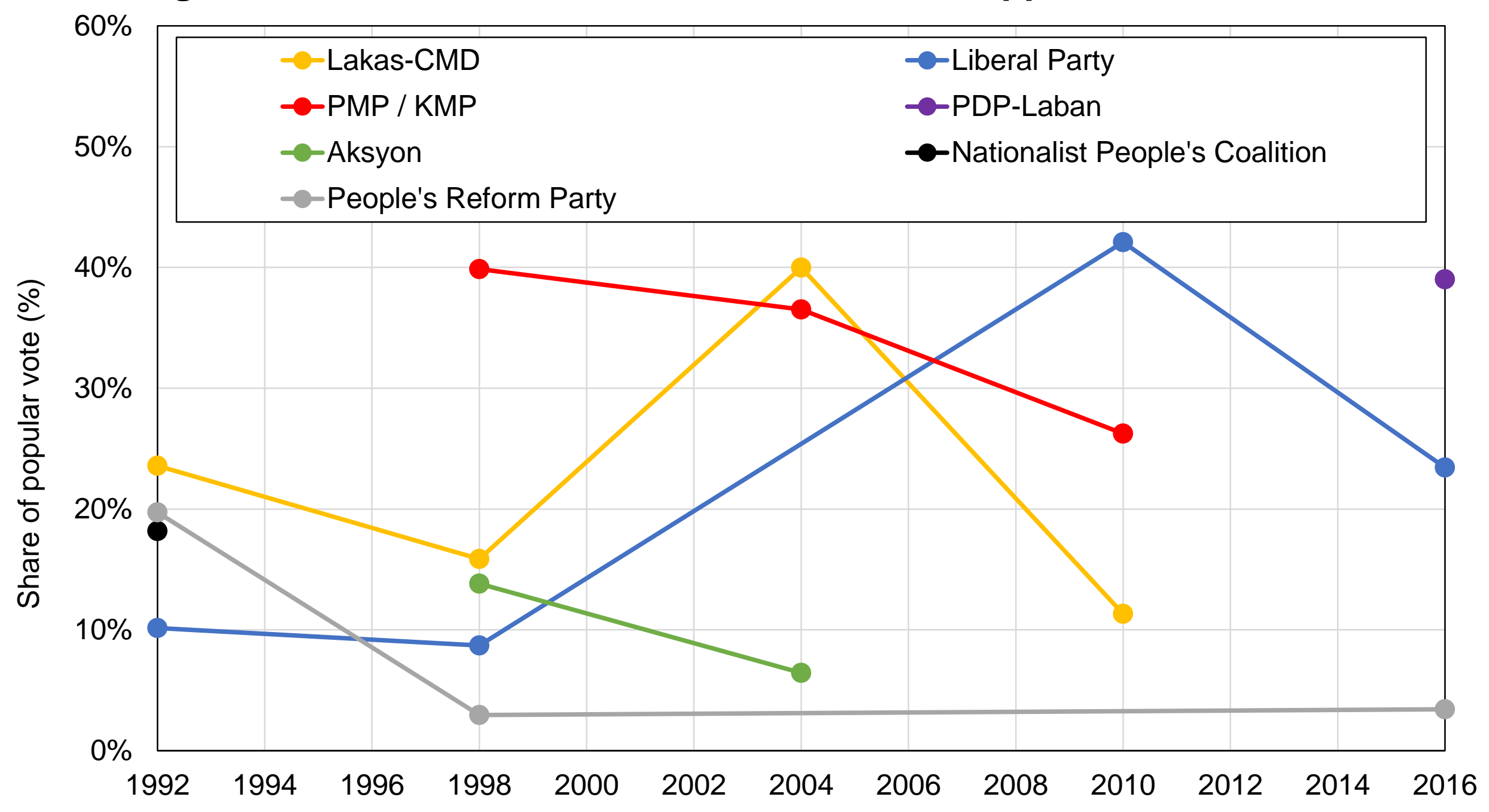

Source: authors' computations using official election results.

Note: the figure shows the share of votes received by specific groups of parties in the first round of presidential elections. 
Figure BA2 - Composition of the electorate by age

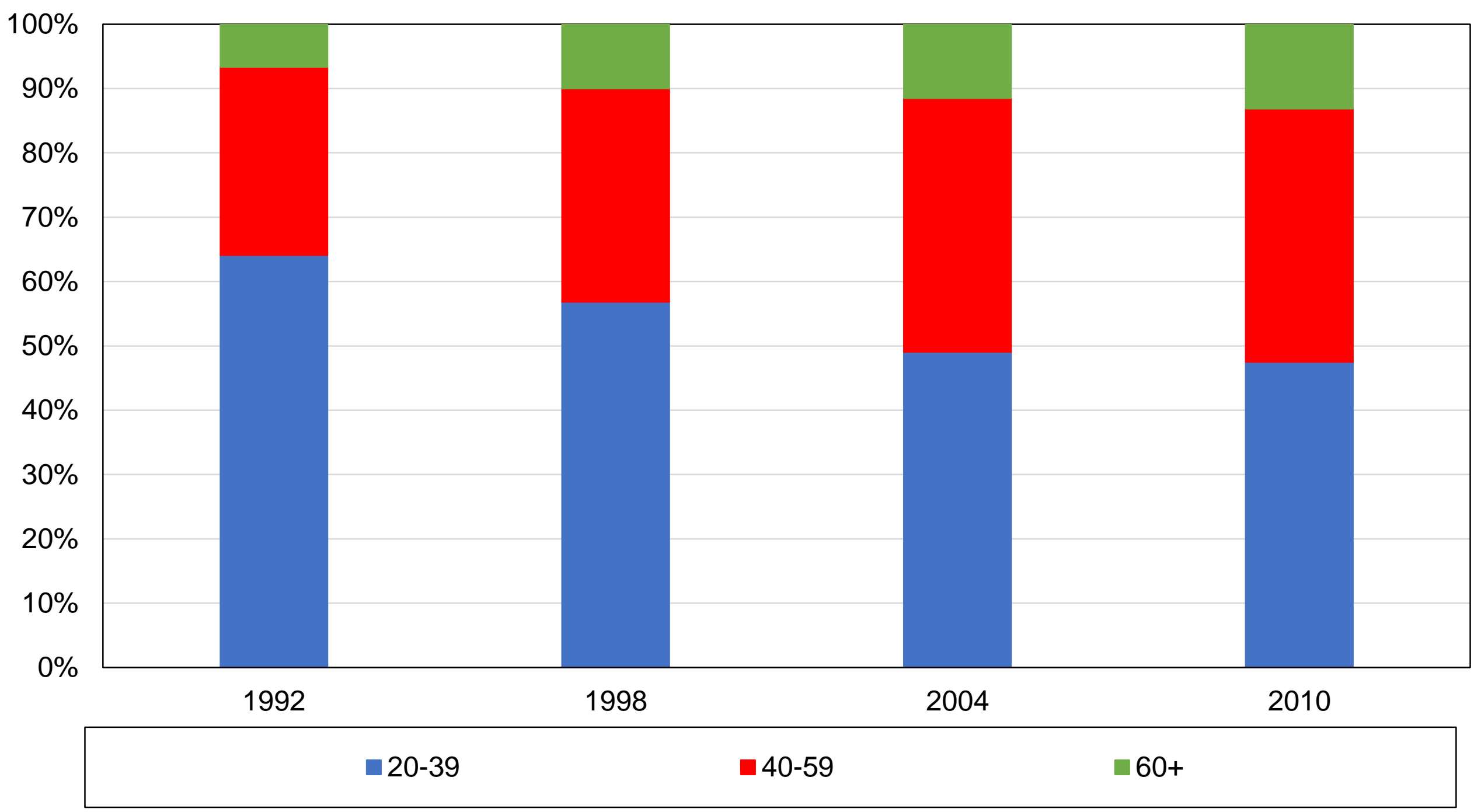

Source: authors' computations using Filipino political attitudes surveys. Note: the figure shows the composition of the electorate by age group. 
Figure BA3 - Composition of the electorate by education

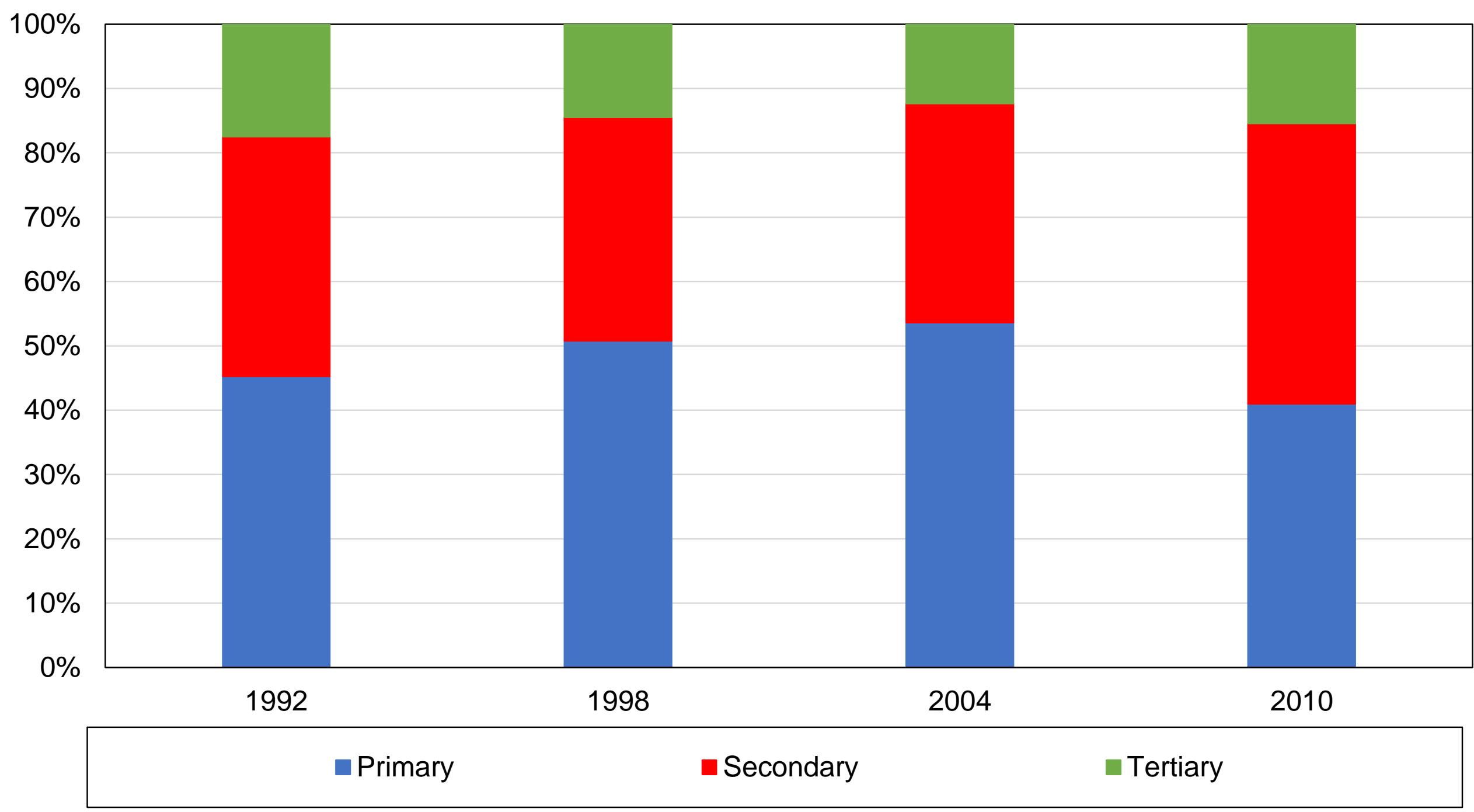

Source: authors' computations using Filipino political attitudes surveys.

Note: the figure shows the composition of the electorate by education level. 
Figure BA4 - Composition of the electorate by ethnicity

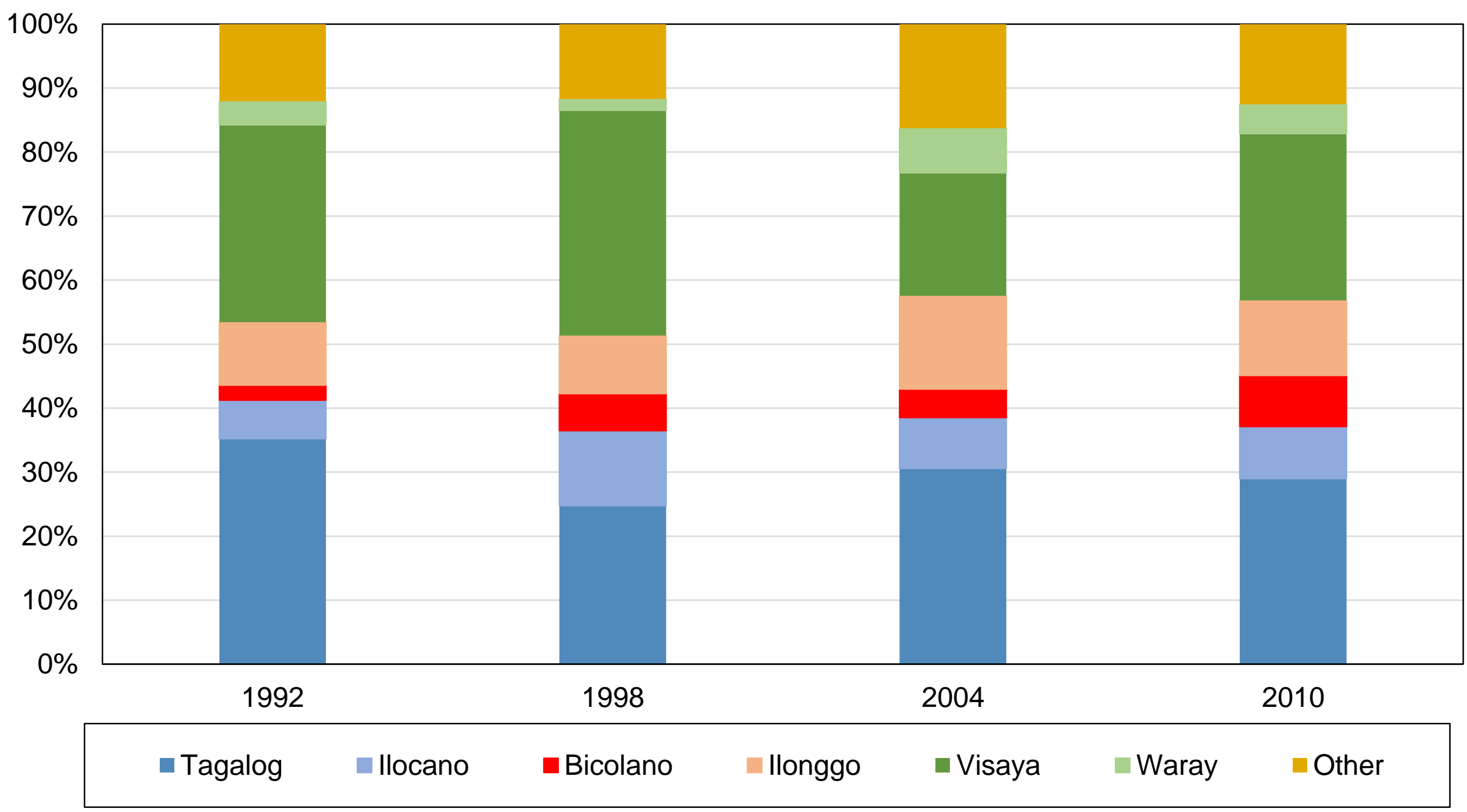

Source: authors' computations using Filipino political attitudes surveys.

Note: the figure shows the composition of the electorate by ethnic group. 


\section{Figure BA5 - Composition of the electorate by region}

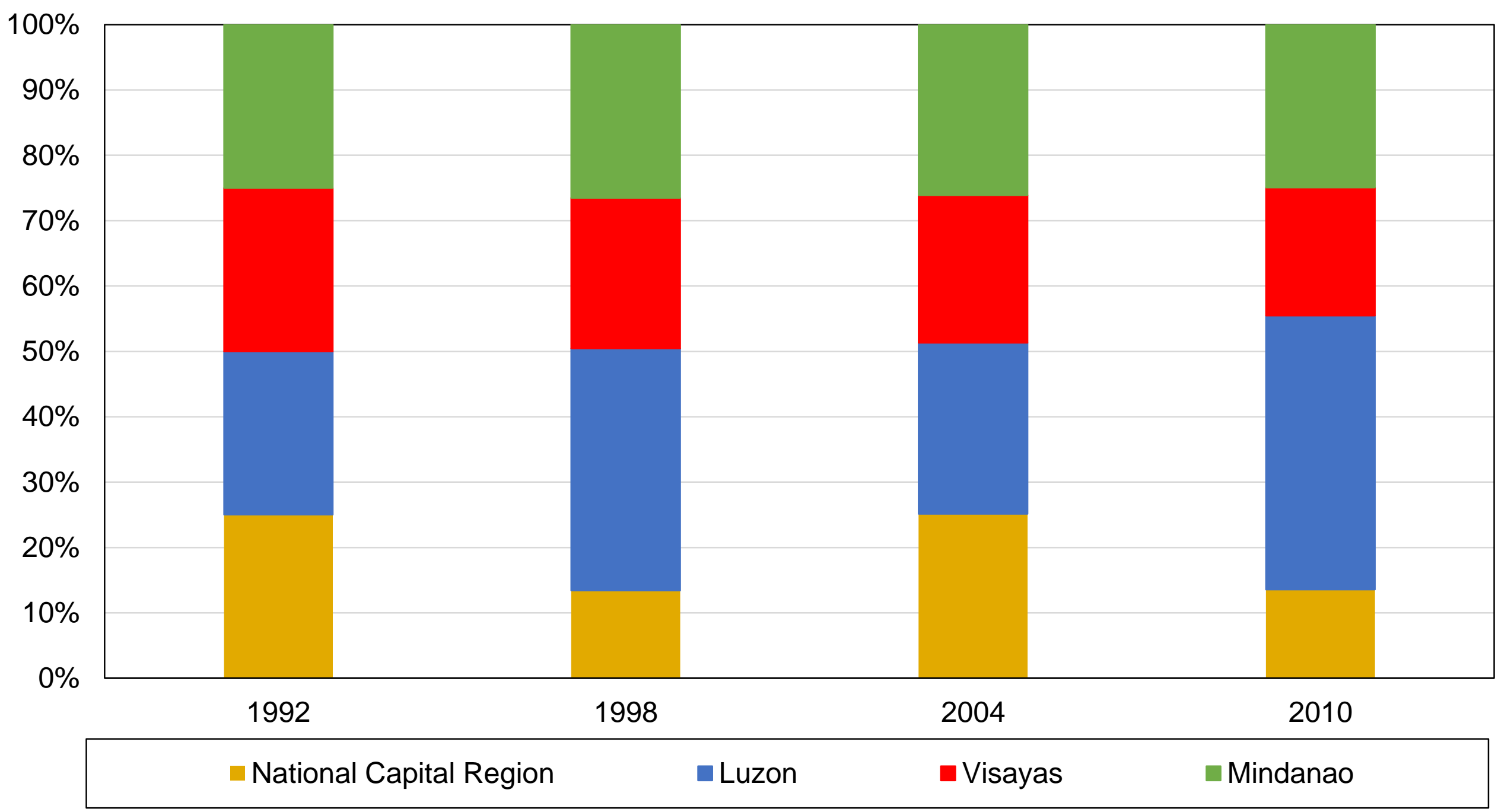

Source: authors' computations using Filipino political attitudes surveys. Note: the figure shows the composition of the electorate by region. 
Figure BA6 - Composition of regions by ethnic group, 2016

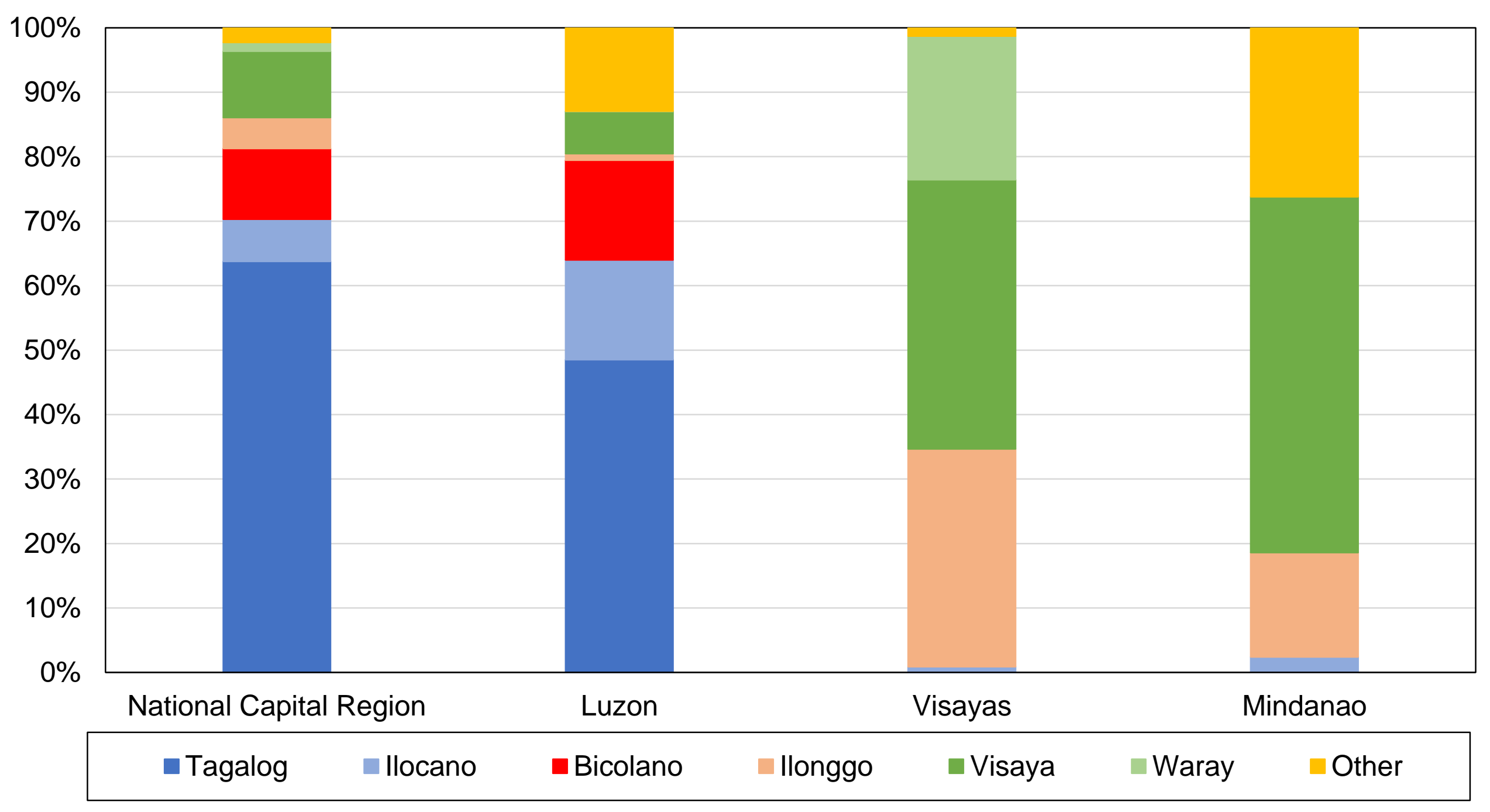

Source: authors' computations using Filipino political attitudes surveys.

Note: the figure shows the composition of regions by ethnic group in 2016. 
Figure BA7 - Composition of income quintiles by education, 2004

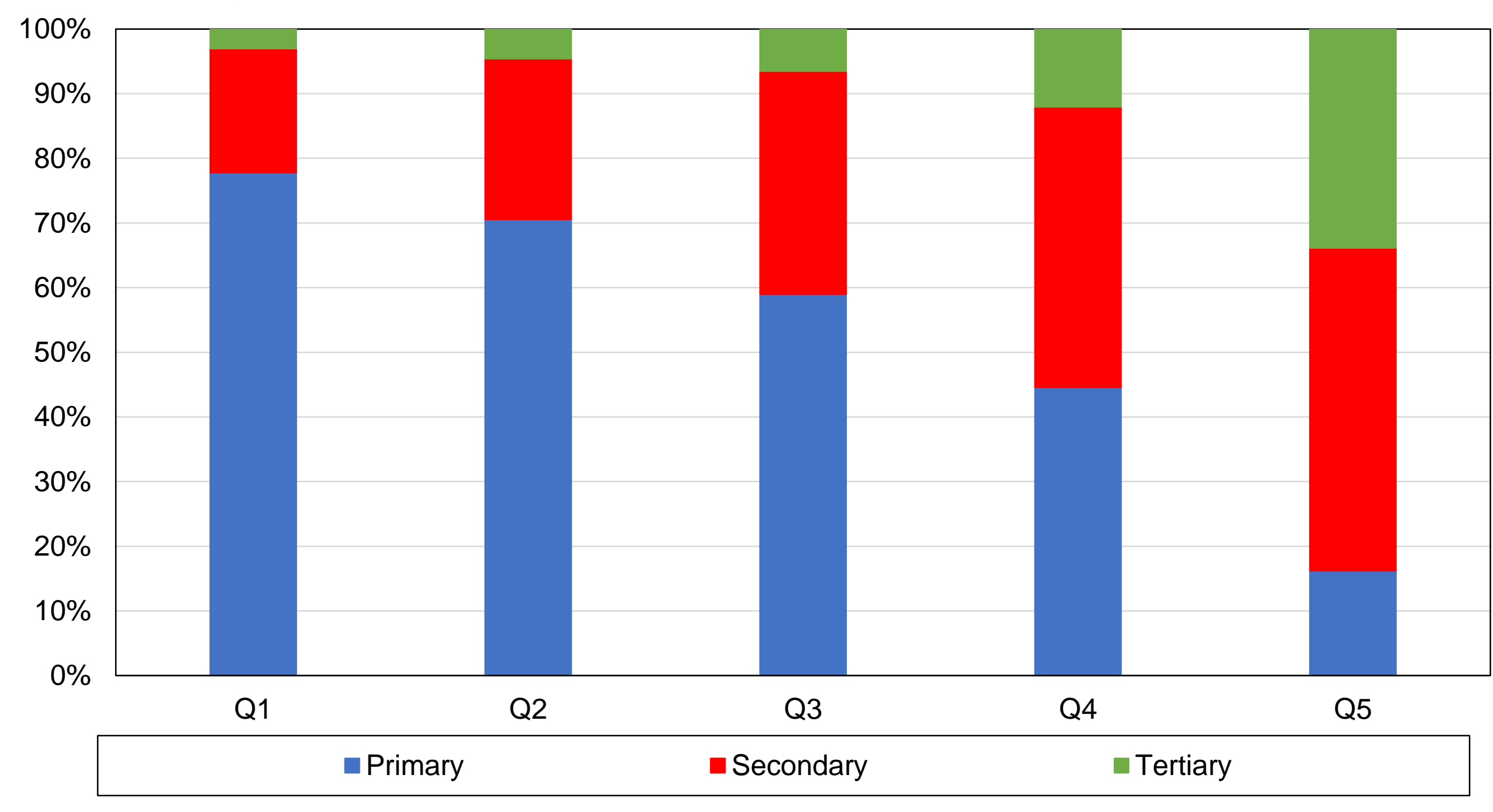

Source: authors' computations using Filipino political attitudes surveys.

Note: the figure shows the composition of income quintiles by education level in 2004 . 
Figure BA8 - Composition of income quintiles by education, 2016

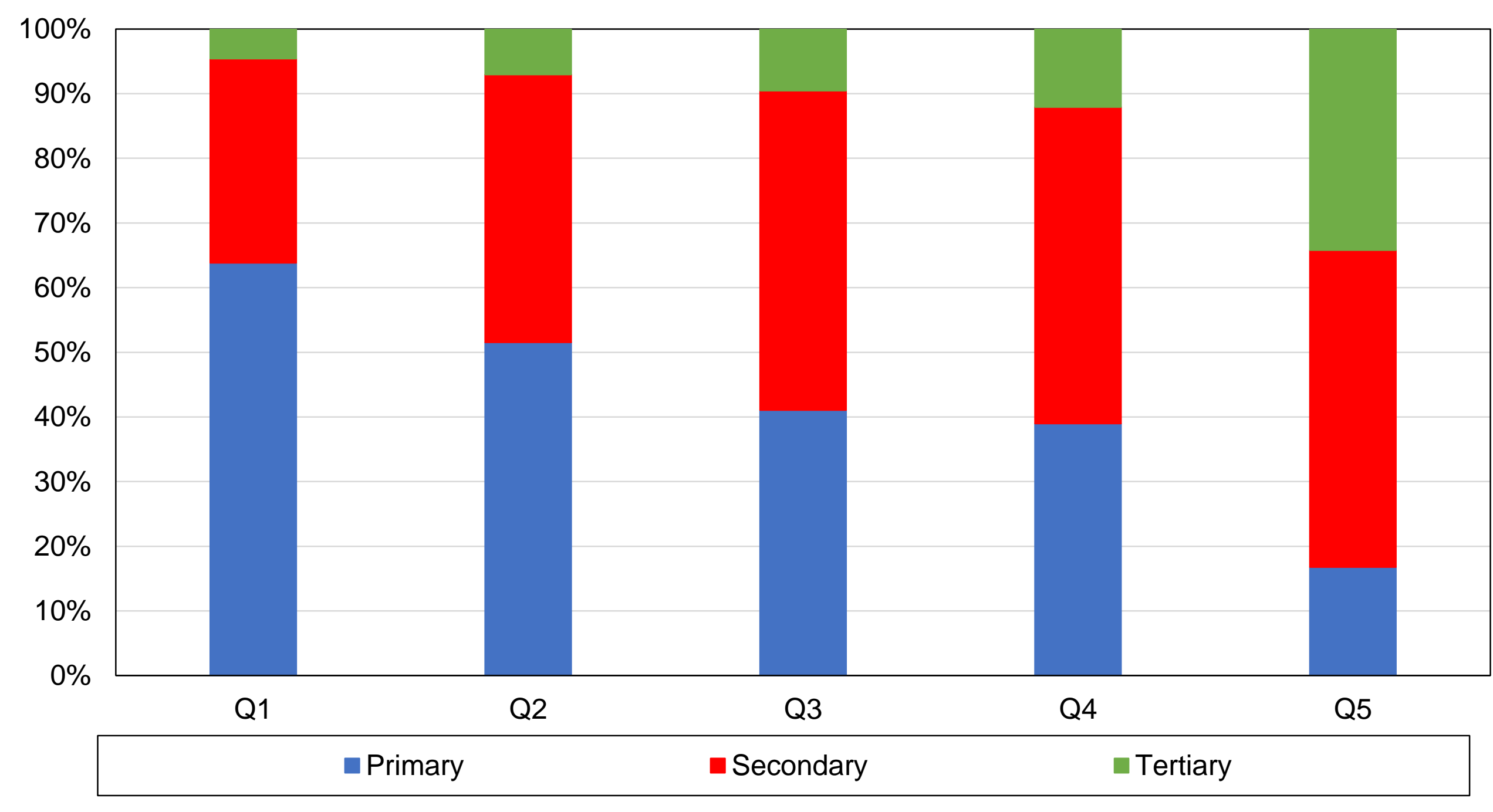

Source: authors' computations using Filipino political attitudes surveys.

Note: the figure shows the composition of income quintiles by education level in 2016. 
Figure BA9 - Composition of income quintiles by region, 2004

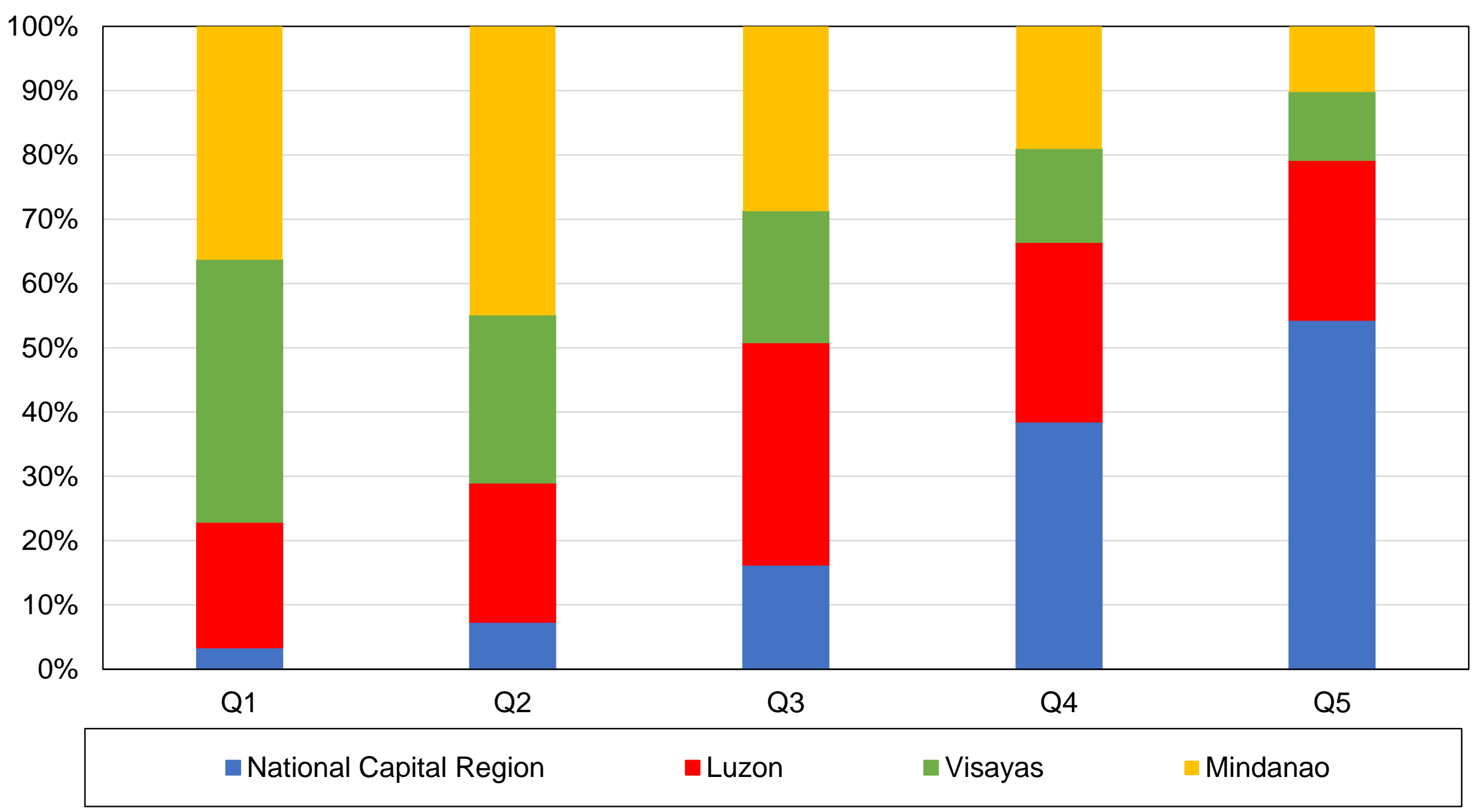

Source: authors' computations using Filipino political attitudes surveys.

Note: the figure shows the composition of income quintiles by region in 2004 . 
Figure BA10 - Composition of income quintiles by region, 2016

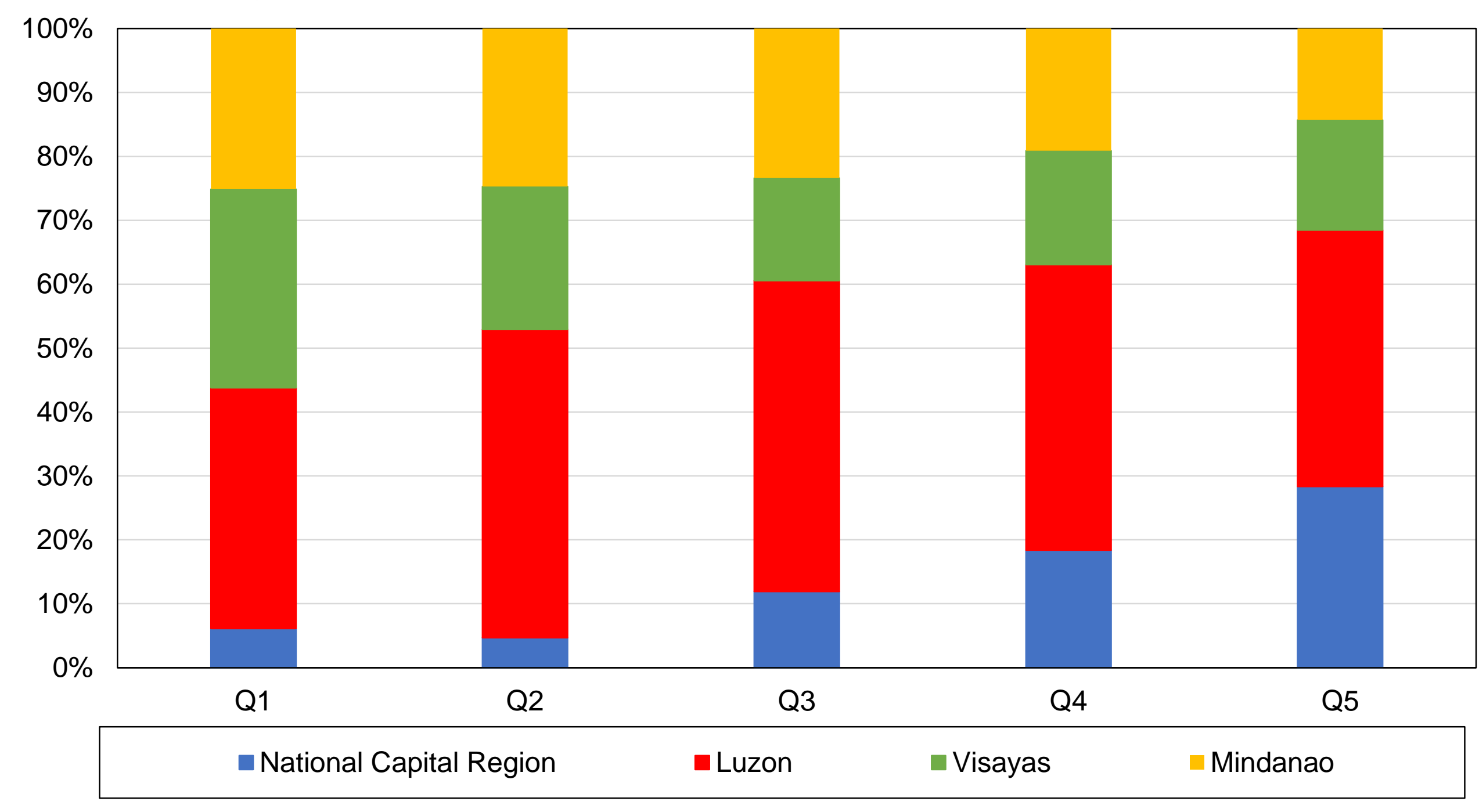

Source: authors' computations using Filipino political attitudes surveys.

Note: the figure shows the composition of income quintiles by region in 2016. 
Figure BA11 - Composition of income quintiles by location, 2004

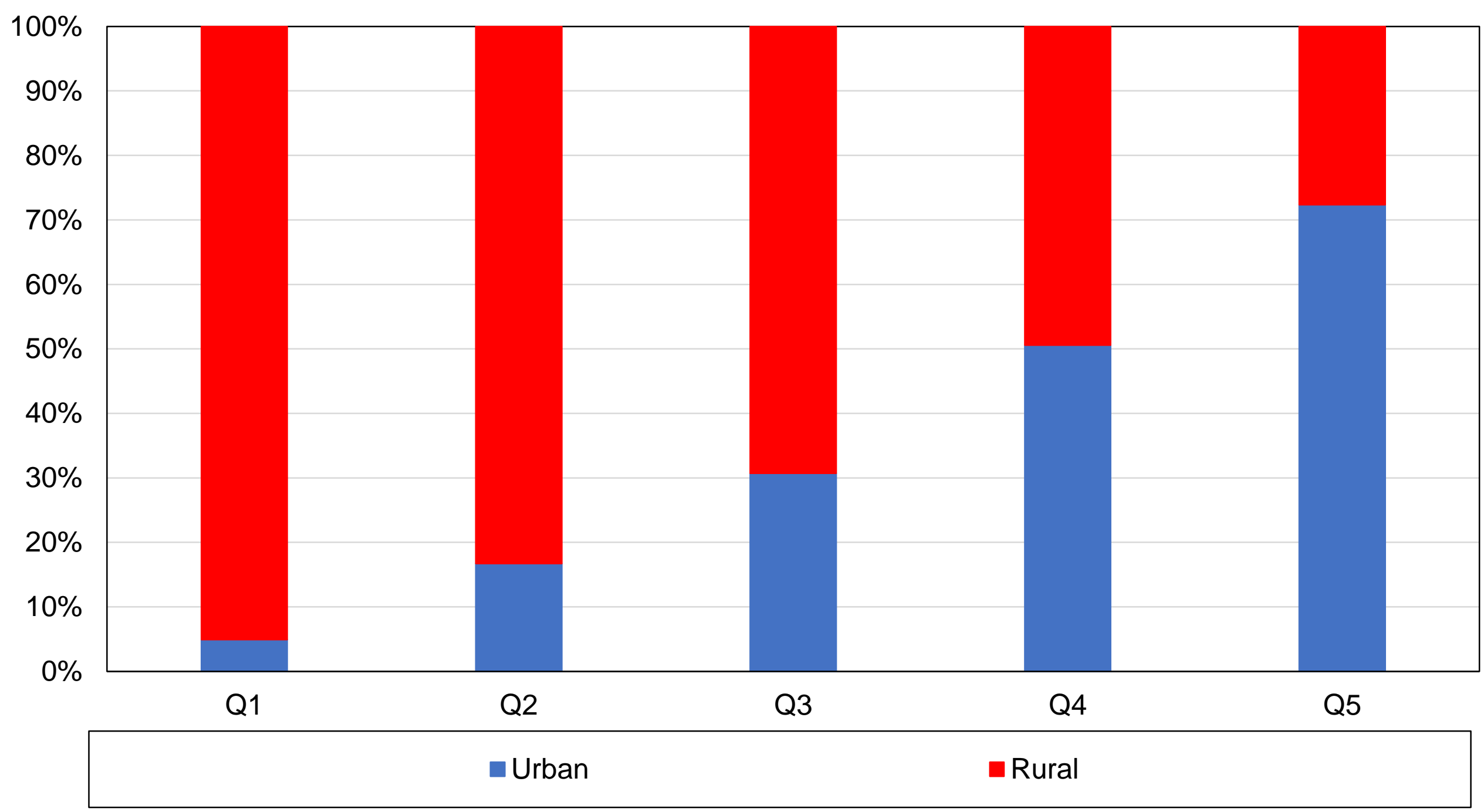

Source: authors' computations using Filipino political attitudes surveys.

Note: the figure shows the composition of income quintiles by rural-urban location in 2004 . 
Figure BA12 - Composition of income quintiles by location, 2016

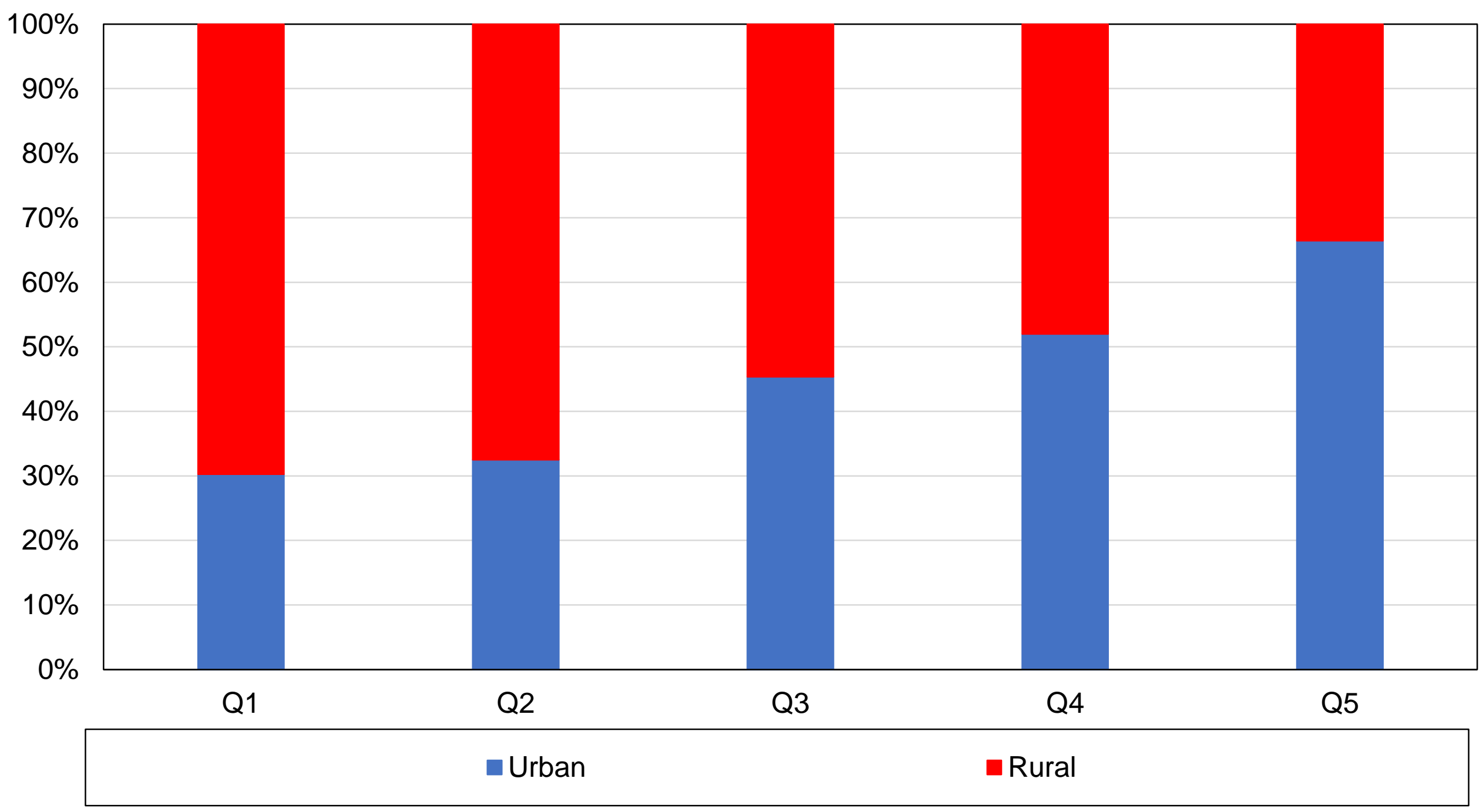

Source: authors' computations using Filipino political attitudes surveys.

Note: the figure shows the composition of income quintiles by rural-urban location in 2016. 
Figure BA13 - Composition of income quintiles by ethnicity, 2004

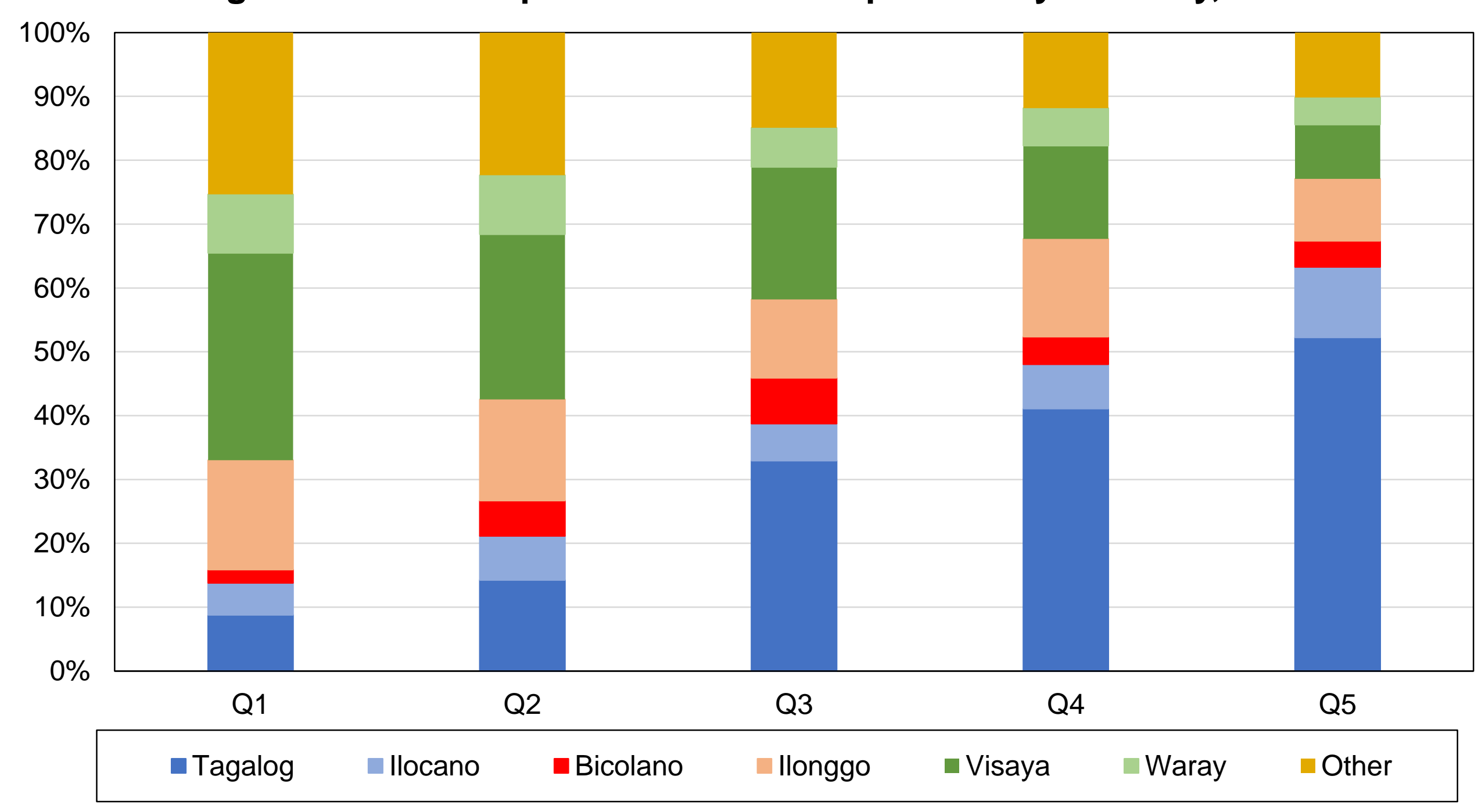

Source: authors' computations using Filipino political attitudes surveys.

Note: the figure shows the composition of income quintiles by ethnicity in 2004 . 
Figure BA14 - Composition of income quintiles by ethnicity, 2016

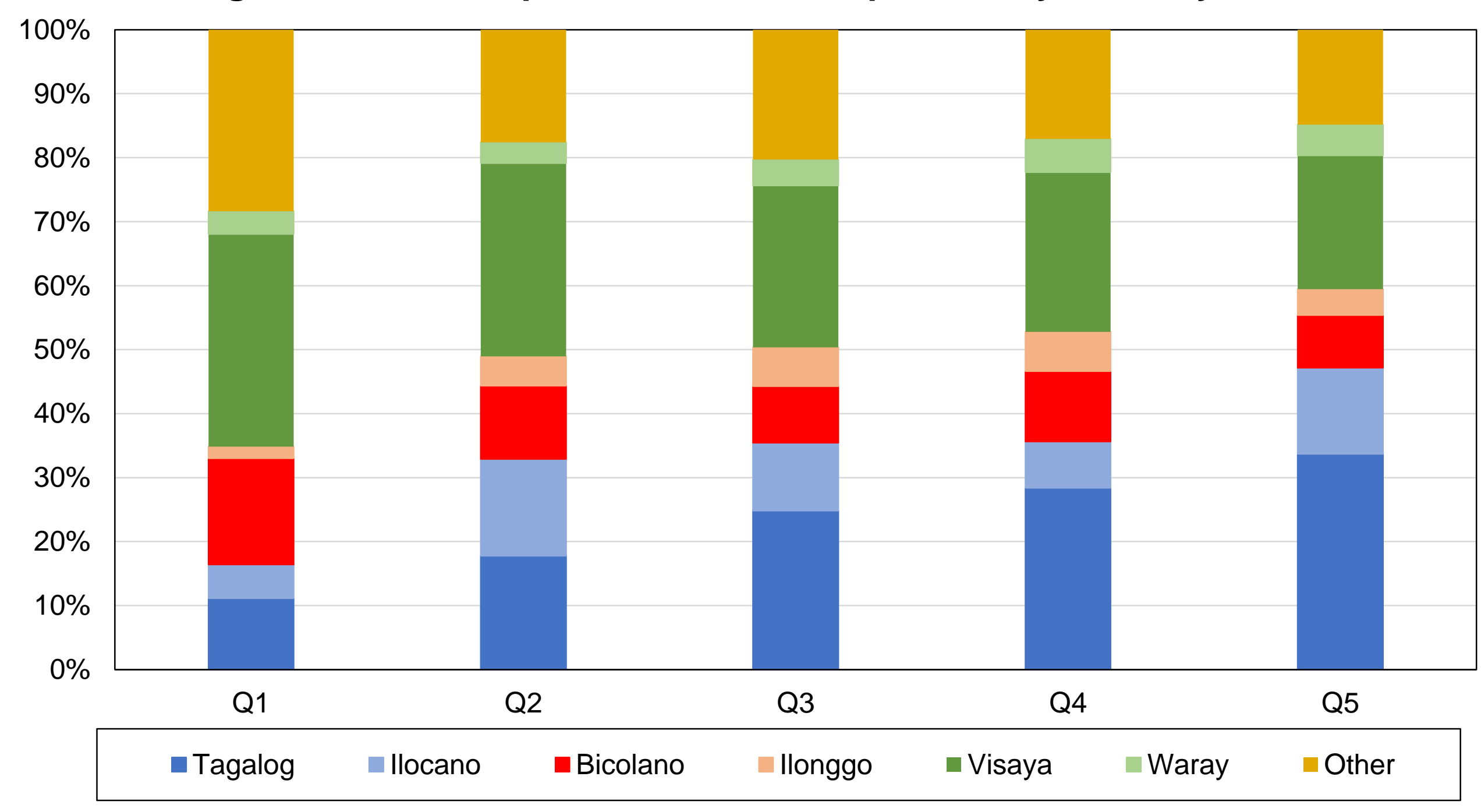

Source: authors' computations using Filipino political attitudes surveys.

Note: the figure shows the composition of income quintiles by ethnicity in 2016 . 
Figure BA9 - Composition of income quintiles by religion, 2004

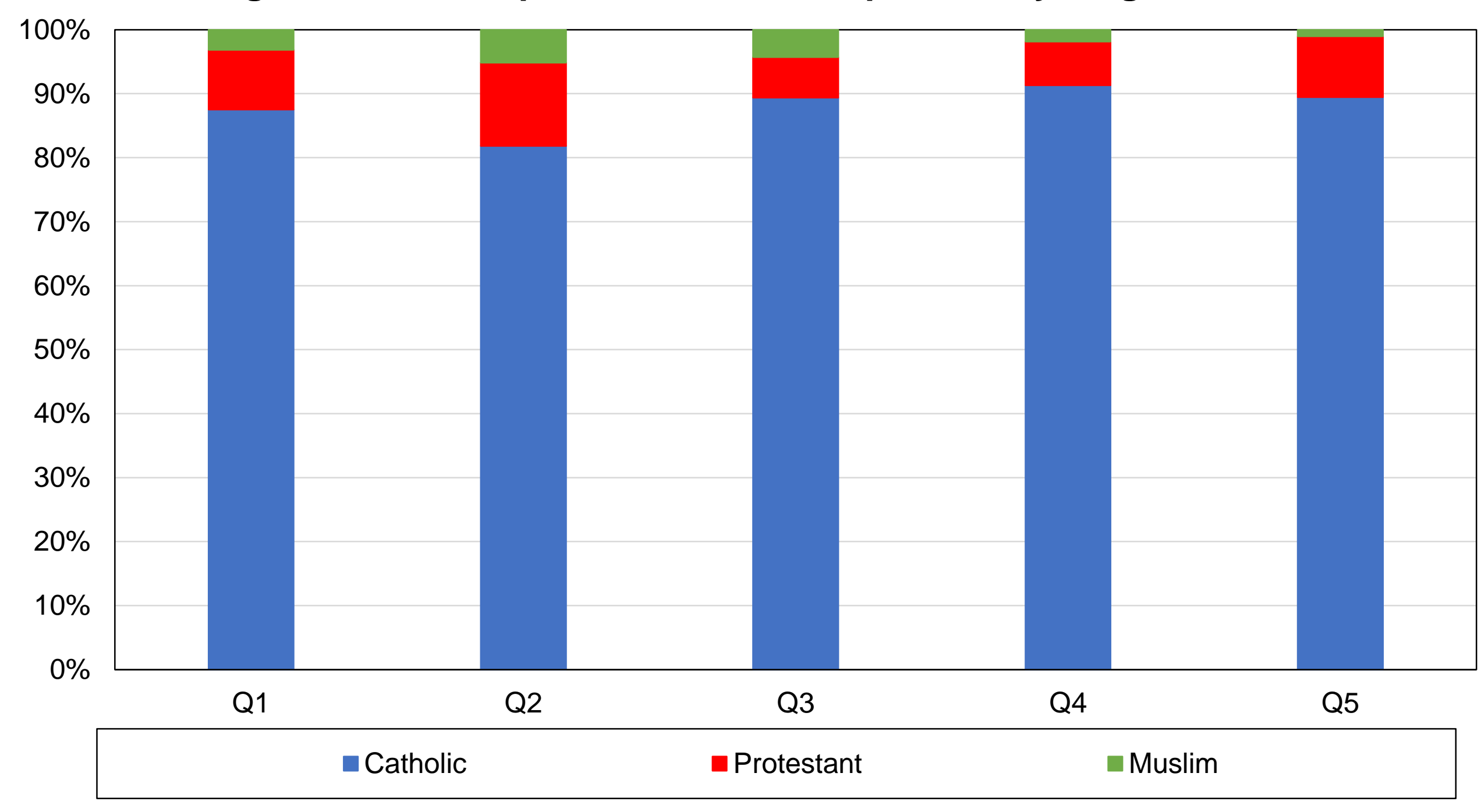

Source: authors' computations using Filipino political attitudes surveys.

Note: the figure shows the composition of income quintiles by religious affiliation in 2004. 


\section{Figure BA9 - Composition of income quintiles by religion, 2016}

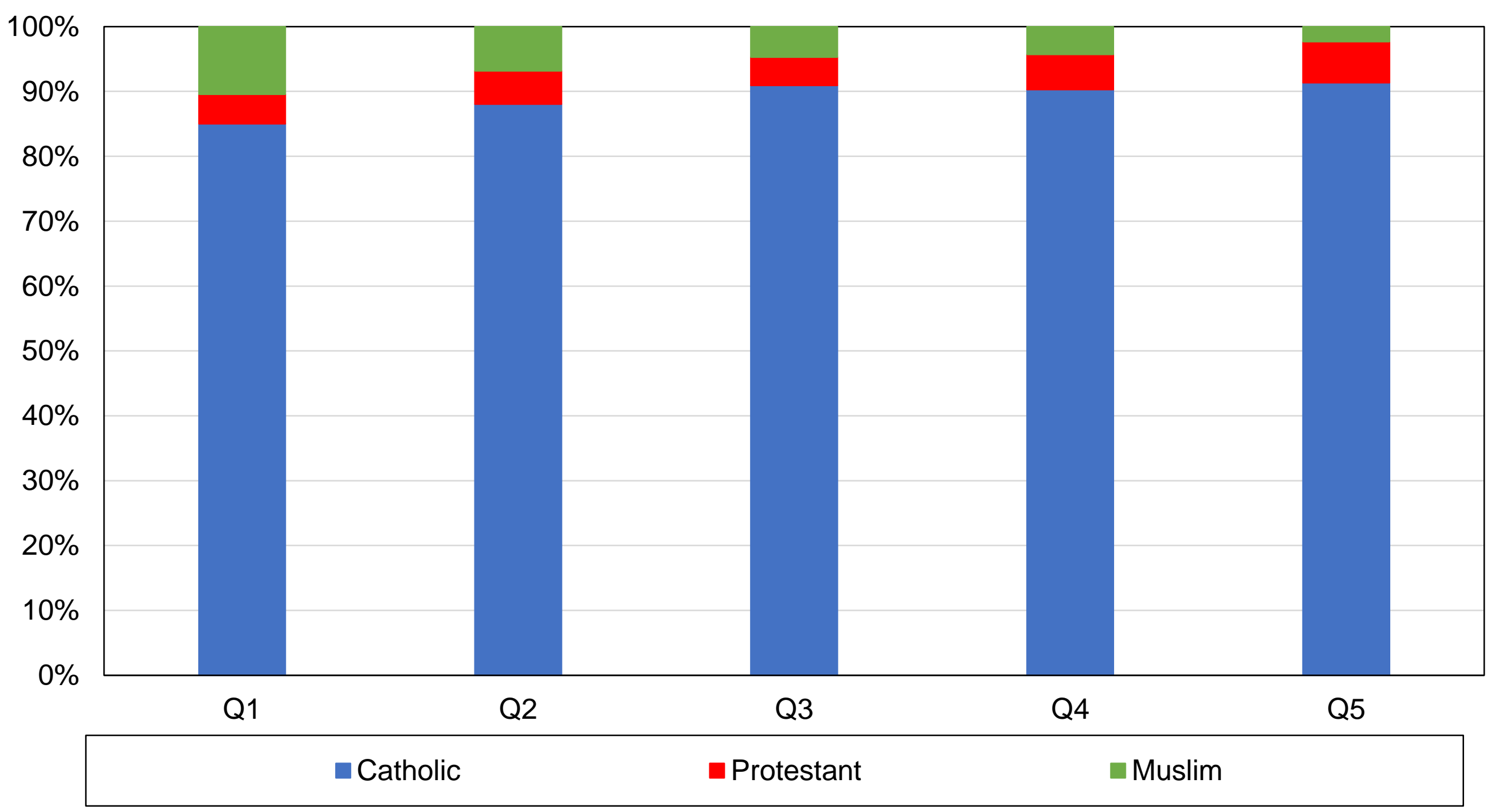

Source: authors' computations using Filipino political attitudes surveys.

Note: the figure shows the composition of income quintiles by religious affiliation in 2016 . 


\section{Figure BB1 - Vote for Estrada / Poe / Binay by education level}

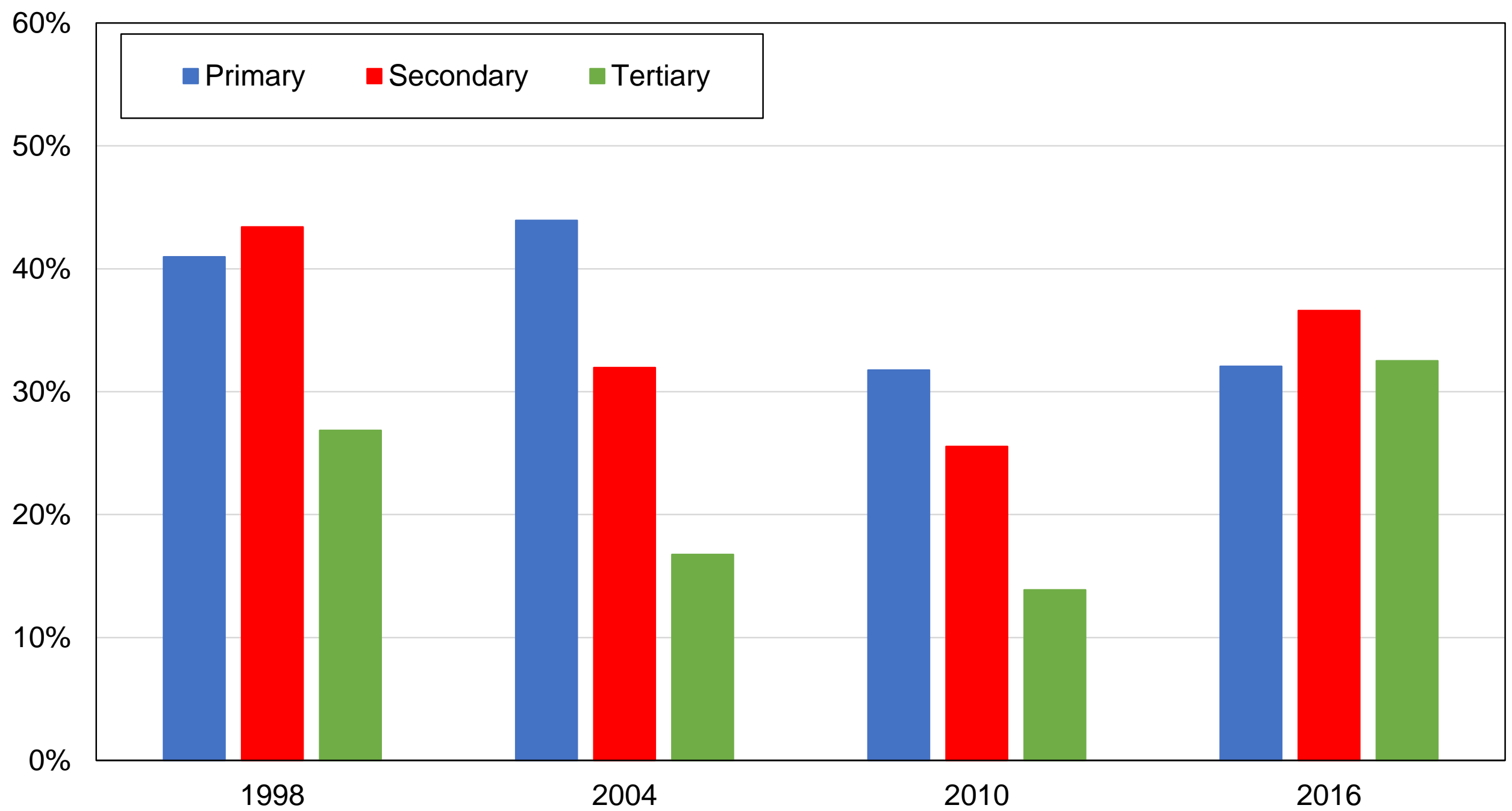

Source: authors' computations using Filipino political attitudes surveys.

Note: the figure shows the share of votes received by Estrada / Poe / Binay in the first round of presidential elections by education level. 
Figure BB2 - Vote for Estrada / Poe / Binay by education group

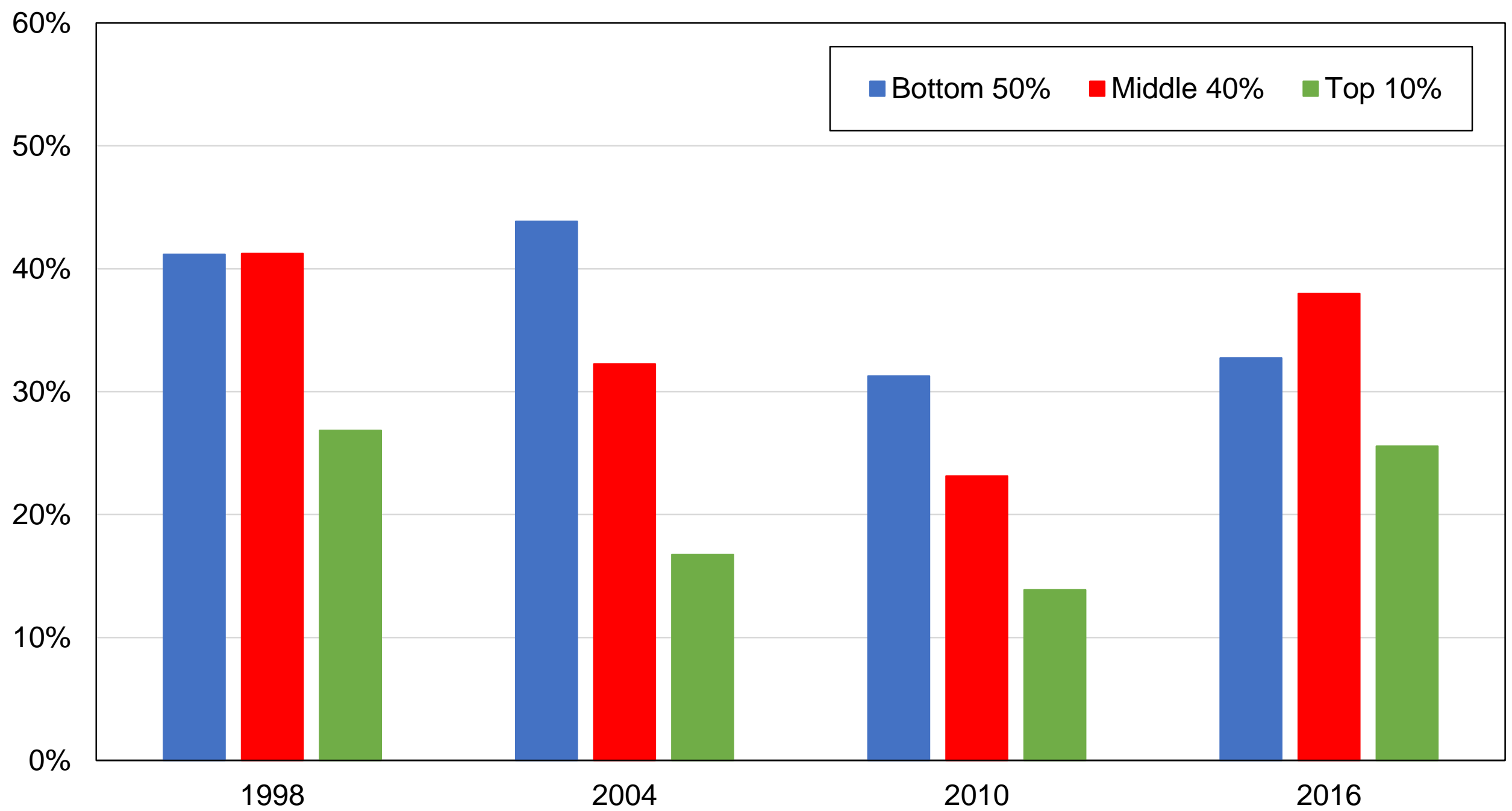

Source: authors' computations using Filipino political attitudes surveys.

Note: the figure shows the share of votes received by Estrada / Poe / Binay in the first round of presidential elections by education group. 
Figure BB3 - Vote for Estrada / Poe / Binay by income group

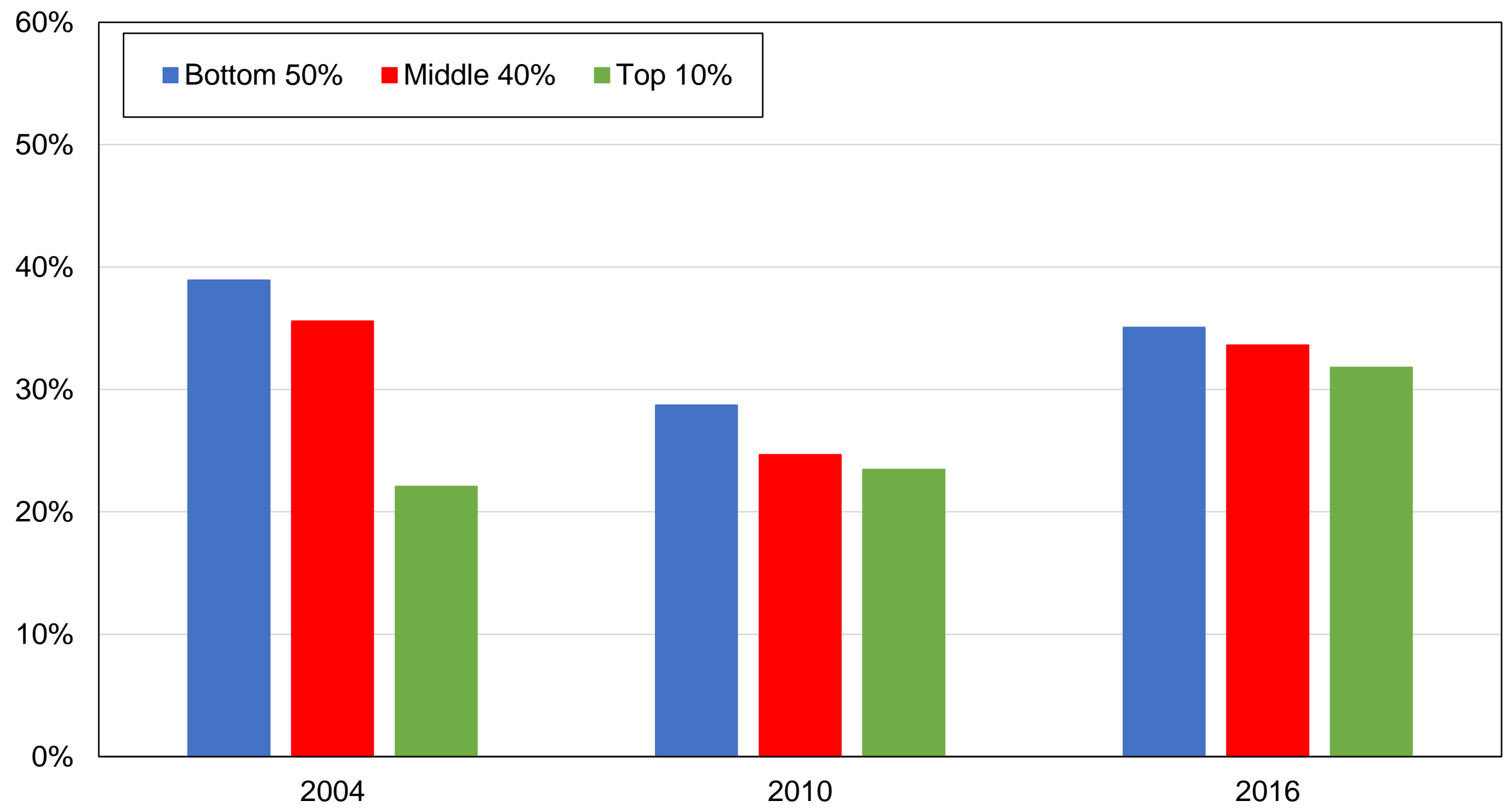

Source: authors' computations using Filipino political attitudes surveys.

Note: the figure shows the share of votes received by Estrada / Poe / Binay in the first round of presidential elections by income group. 
Figure BB4 - Vote for Estrada / Poe / Binay by region

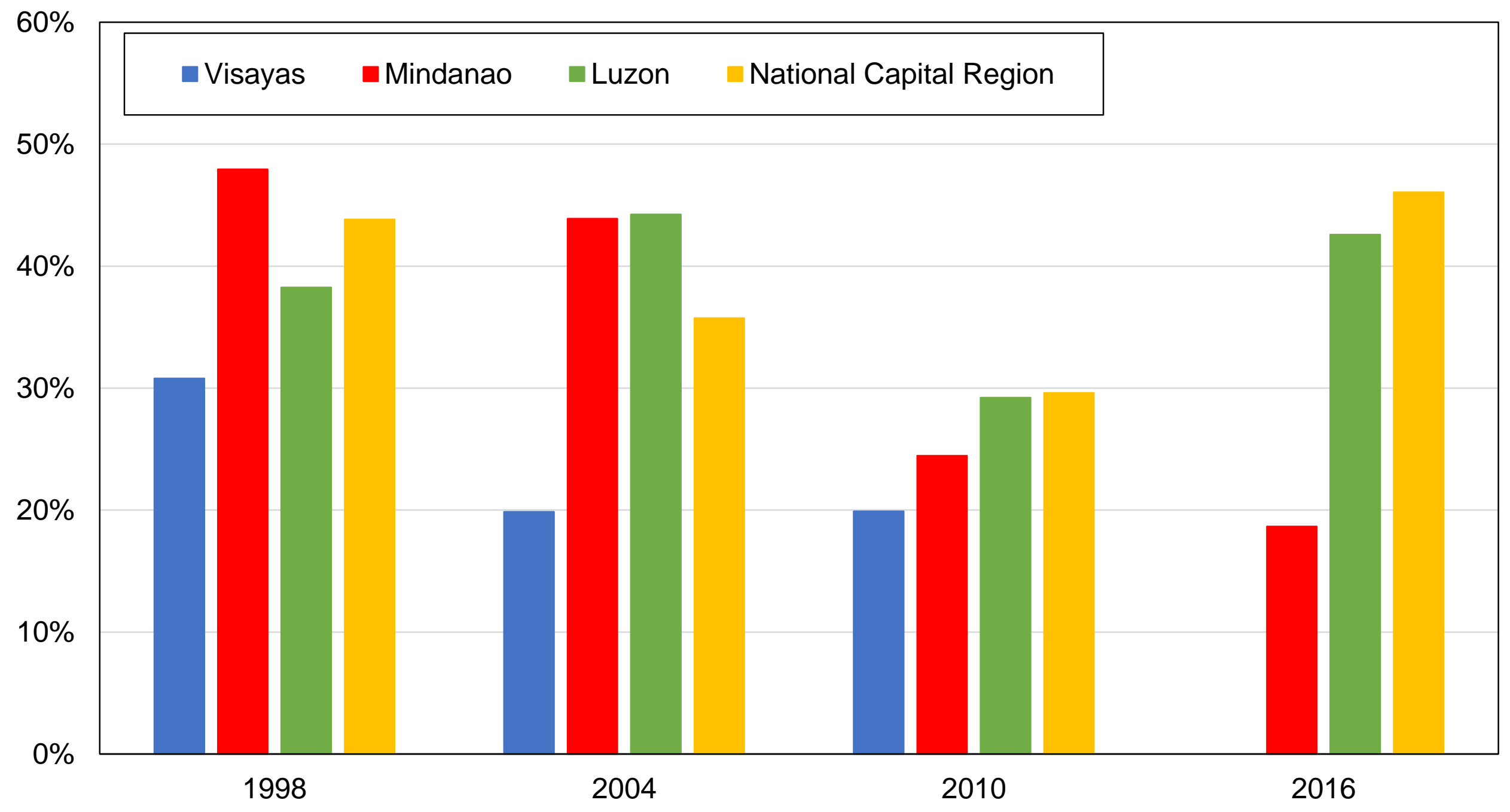

Source: authors' computations using Filipino political attitudes surveys.

Note: the figure shows the share of votes received by Estrada / Poe / Binay in the first round of presidential elections by region. 


\section{Figure BB5 - Vote for Estrada / Poe / Binay by ethnicity}

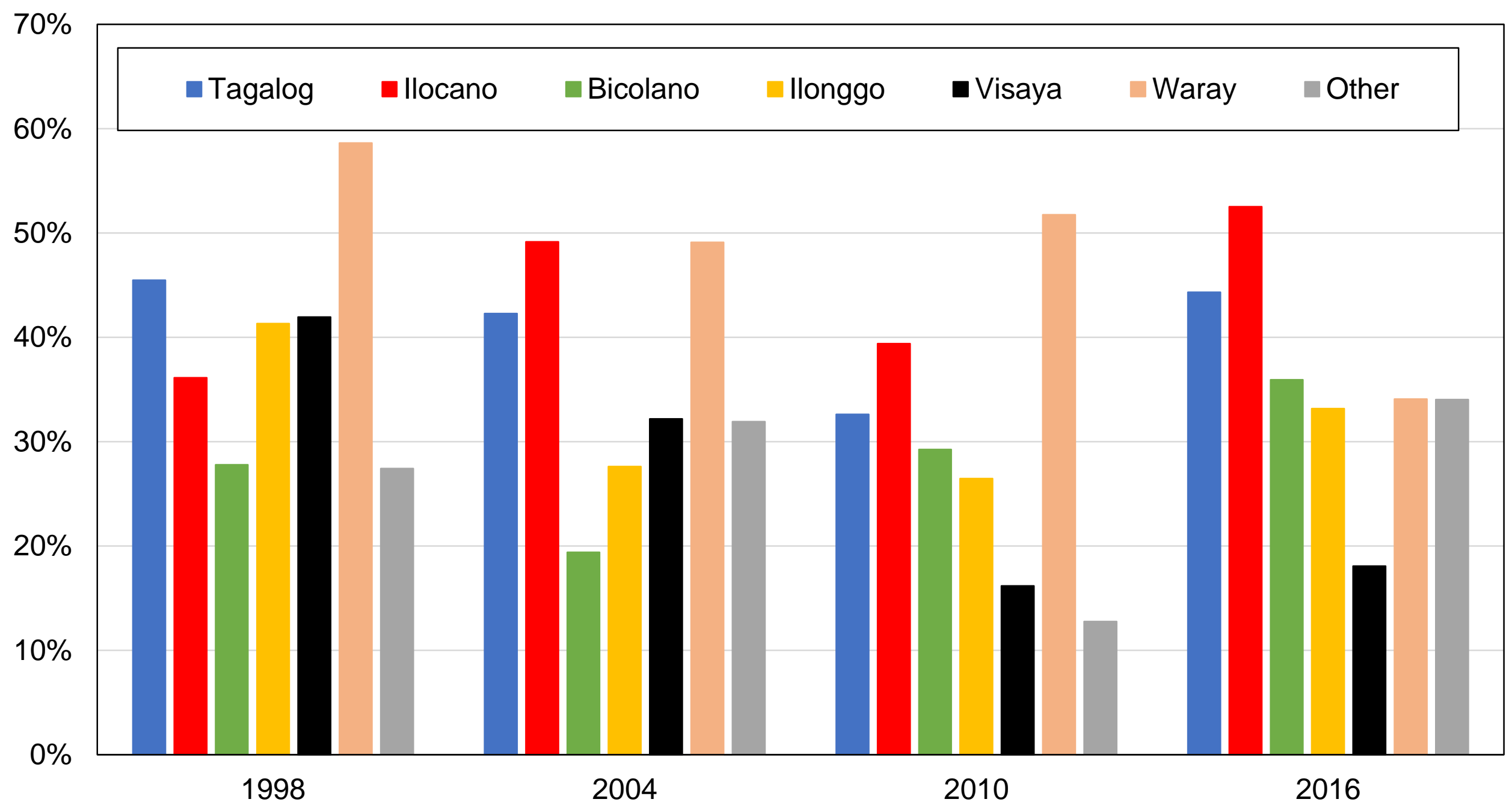

Source: authors' computations using Filipino political attitudes surveys.

Note: the figure shows the share of votes received by Estrada / Poe / Binay in the first round of presidential elections by ethnic group. 
Figure BB6 - Vote for Estrada / Poe / Binay by religion

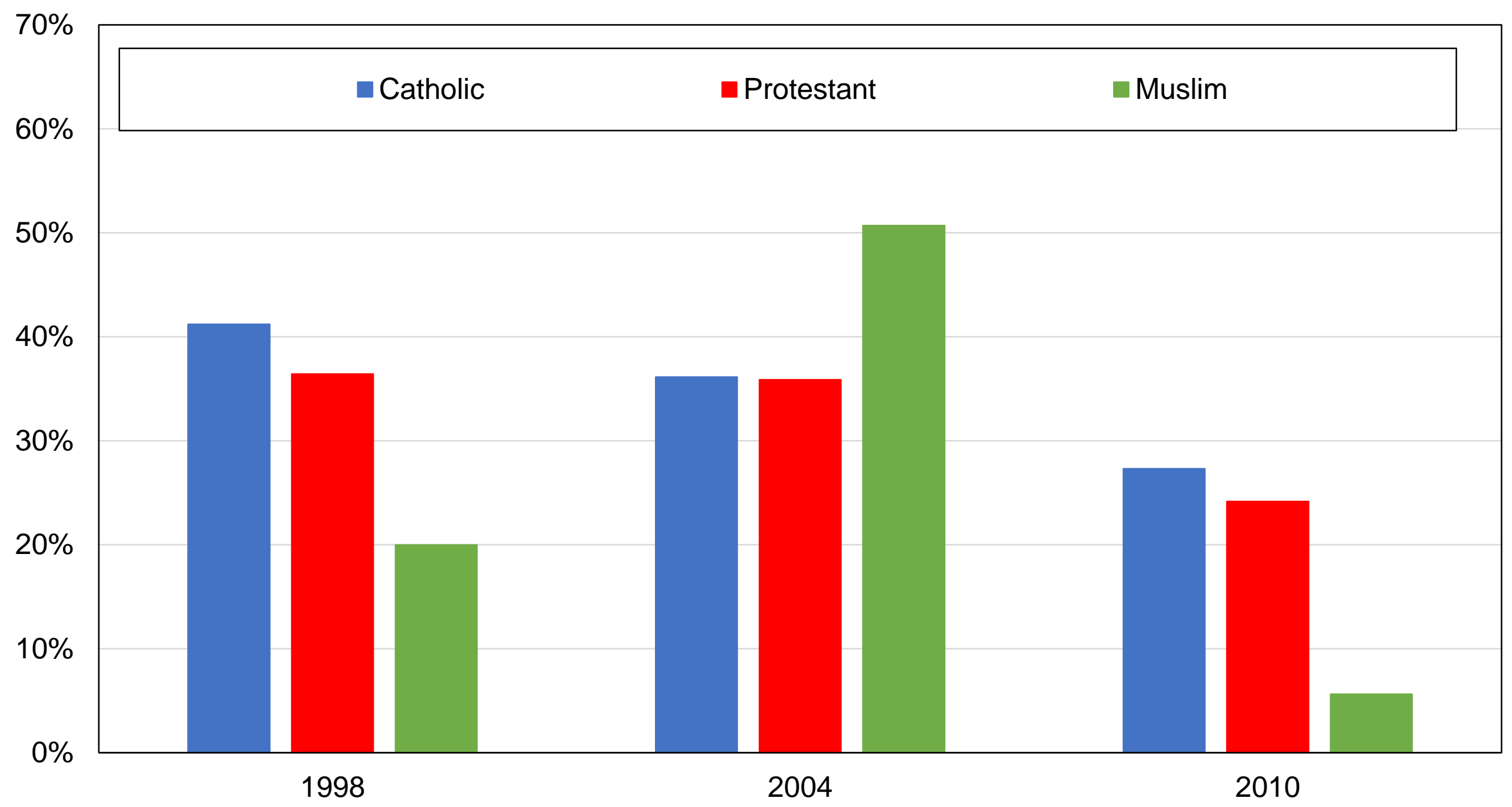

Source: authors' computations using Filipino political attitudes surveys.

Note: the figure shows the share of votes received by Estrada / Poe / Binay in the first round of presidential elections by religion. 


\section{Figure BC1 - Support for Estrada / Poe / Binay among highest-educated voters}

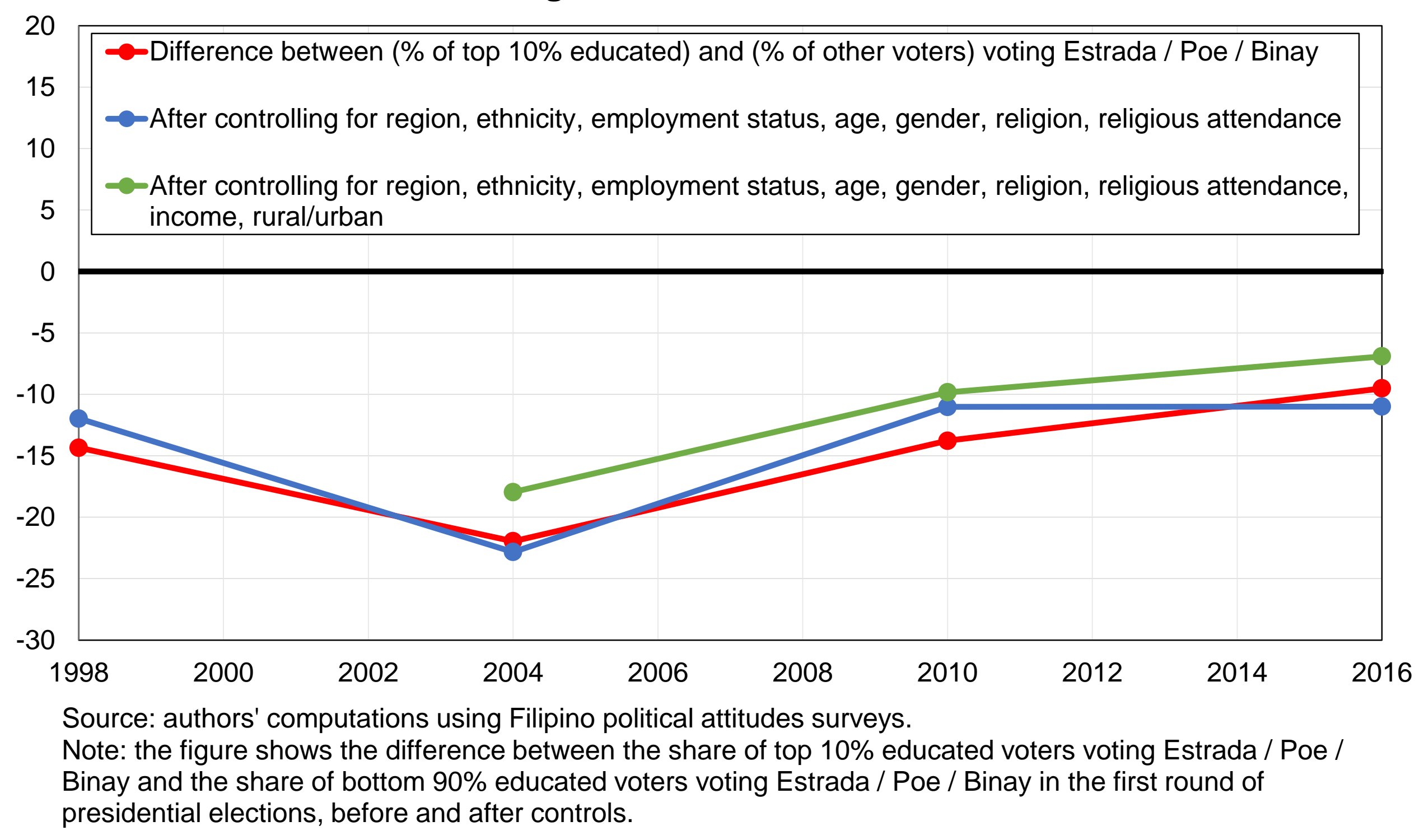




\section{Figure BC2 - Support for Estrada / Poe / Binay among top-income voters}

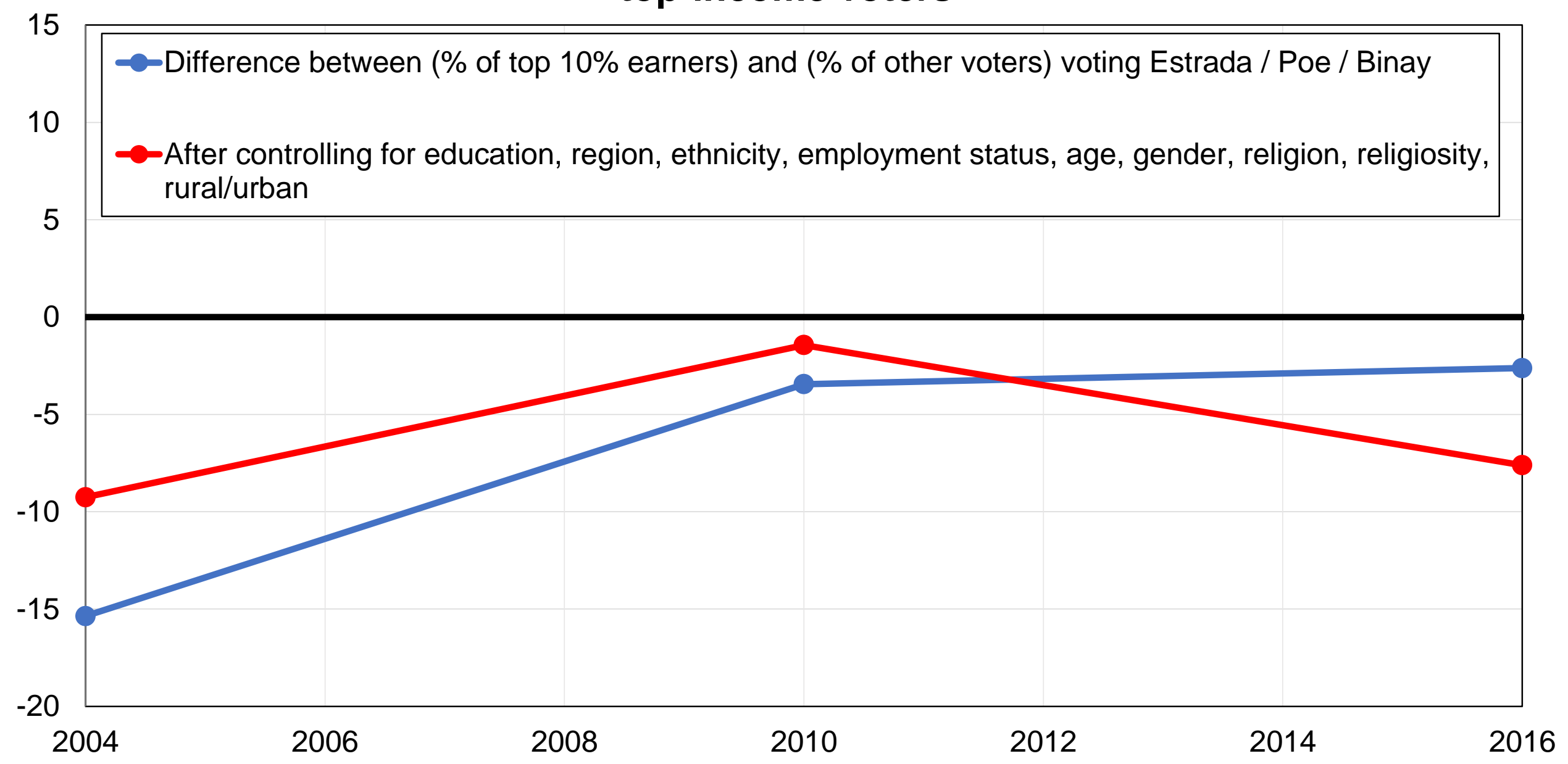

Source: authors' computations using Filipino political attitudes surveys.

Note: the figure shows the difference between the share of top 10\% earners voting Estrada / Poe / Binay and the share of bottom 90\% earners voting Estrada / Poe / Binay in the first round of presidential elections, before and after controls. 


\begin{tabular}{|c|c|c|c|}
\hline \multicolumn{4}{|c|}{ Table BA1 - Survey data sources } \\
\hline Year & Survey & Source & Sample size \\
\hline 1998 & World Values Survey, 2001 & WVS & 1200 \\
\hline 2004 & Comparative Study of Electoral Systems & CSES & 1200 \\
\hline 2010 & Comparative Study of Electoral Systems & CSES & 1200 \\
\hline 2016 & Comparative Study of Electoral Systems & CSES & 1200 \\
\hline \multicolumn{4}{|c|}{$\begin{array}{l}\text { Source: authors' elaboration. } \\
\text { Note: the table shows the surveys used, the source from which these surveys can be obtained, and the } \\
\text { sample size of each survey. WVS: World Values Surveys; CSES: Comparative Study of Electoral Systems. }\end{array}$} \\
\hline
\end{tabular}


Table BA2 - Descriptive Statistics

\begin{tabular}{|l|cccc|}
\hline & 1992 & 1998 & 2004 & 2010 \\
\hline Age: $20-40$ & $64 \%$ & $57 \%$ & $49 \%$ & $47 \%$ \\
Age: $40-60$ & $29 \%$ & $33 \%$ & $39 \%$ & $39 \%$ \\
Age: $60+$ & $7 \%$ & $10 \%$ & $12 \%$ & $13 \%$ \\
Education: Primary & $45 \%$ & $51 \%$ & $54 \%$ & $41 \%$ \\
Education: Secondary & $37 \%$ & $35 \%$ & $34 \%$ & $44 \%$ \\
Education: Tertiary & $17 \%$ & $14 \%$ & $12 \%$ & $15 \%$ \\
Ethnicity: Bicolano & $2 \%$ & $6 \%$ & $4 \%$ & $8 \%$ \\
Ethnicity: llocano & $6 \%$ & $12 \%$ & $8 \%$ & $8 \%$ \\
Ethnicity: llonggo & $10 \%$ & $9 \%$ & $15 \%$ & $12 \%$ \\
Ethnicity: Other & $12 \%$ & $12 \%$ & $16 \%$ & $13 \%$ \\
Ethnicity: Tagalog & $35 \%$ & $25 \%$ & $31 \%$ & $29 \%$ \\
Ethnicity: Visaya & $31 \%$ & $35 \%$ & $19 \%$ & $26 \%$ \\
Ethnicity: Waray & $4 \%$ & $2 \%$ & $7 \%$ & $5 \%$ \\
Region: National Capital Region & $25 \%$ & $13 \%$ & $25 \%$ & $14 \%$ \\
Region: Luzon & $25 \%$ & $37 \%$ & $26 \%$ & $42 \%$ \\
Region: Visayas & $25 \%$ & $23 \%$ & $23 \%$ & $20 \%$ \\
Region: Mindanao & $25 \%$ & $27 \%$ & $26 \%$ & $25 \%$ \\
Religion: Catholic & $87 \%$ & $84 \%$ & $88 \%$ & $92 \%$ \\
Religion: Protestant & $12 \%$ & $12 \%$ & $9 \%$ & $4 \%$ \\
Religion: Muslim & $1 \%$ & $4 \%$ & $3 \%$ & $4 \%$ \\
Church attendance: Less than monthly & $10 \%$ & $19 \%$ & $16 \%$ & $14 \%$ \\
Church attendance: Monthly or more & $90 \%$ & $81 \%$ & $84 \%$ & $86 \%$ \\
Rural areas & & $43 \%$ & $64 \%$ & $51 \%$ \\
\hline
\end{tabular}




\begin{tabular}{|c|c|c|c|c|c|c|c|c|}
\hline \multicolumn{9}{|c|}{ Table BA3 - Structure of the vote in 1998} \\
\hline & PMP & Lakas & Laban & Aksyon & Kilusang & Liberal & NPC & PROMDI \\
\hline \multicolumn{9}{|l|}{ Education } \\
\hline Primary & $41 \%$ & $13 \%$ & $4 \%$ & $16 \%$ & $2 \%$ & $9 \%$ & $2 \%$ & $12 \%$ \\
\hline Secondary & $43 \%$ & $15 \%$ & $4 \%$ & $12 \%$ & $2 \%$ & $8 \%$ & $1 \%$ & $13 \%$ \\
\hline Tertiary & $27 \%$ & $29 \%$ & $5 \%$ & $11 \%$ & $1 \%$ & $10 \%$ & $2 \%$ & $13 \%$ \\
\hline Bicolano & $28 \%$ & $3 \%$ & $3 \%$ & $47 \%$ & $1 \%$ & $14 \%$ & $4 \%$ & $0 \%$ \\
\hline \multicolumn{8}{|l|}{ Ethnicity } & $6 \%$ \\
\hline llonggo & $41 \%$ & $24 \%$ & $3 \%$ & $11 \%$ & $2 \%$ & $5 \%$ & $2 \%$ & $9 \%$ \\
\hline Other & $27 \%$ & $26 \%$ & $6 \%$ & $17 \%$ & $1 \%$ & $14 \%$ & $2 \%$ & $6 \%$ \\
\hline Tagalog & $45 \%$ & $15 \%$ & $3 \%$ & $12 \%$ & $3 \%$ & $10 \%$ & $1 \%$ & $7 \%$ \\
\hline Visaya & $42 \%$ & $14 \%$ & $4 \%$ & $6 \%$ & $1 \%$ & $5 \%$ & $1 \%$ & $25 \%$ \\
\hline Waray & $59 \%$ & $16 \%$ & $8 \%$ & $0 \%$ & $1 \%$ & $14 \%$ & $0 \%$ & $0 \%$ \\
\hline \multicolumn{9}{|l|}{ Region } \\
\hline NCR & $44 \%$ & $9 \%$ & $4 \%$ & $21 \%$ & $3 \%$ & $12 \%$ & $2 \%$ & $3 \%$ \\
\hline Luzon & $38 \%$ & $14 \%$ & $4 \%$ & $20 \%$ & $3 \%$ & $11 \%$ & $2 \%$ & $7 \%$ \\
\hline Visayas & $31 \%$ & $16 \%$ & $3 \%$ & $7 \%$ & $1 \%$ & $7 \%$ & $2 \%$ & $31 \%$ \\
\hline Mindanao & $48 \%$ & $21 \%$ & $5 \%$ & $8 \%$ & $1 \%$ & $6 \%$ & $1 \%$ & $9 \%$ \\
\hline \multicolumn{9}{|l|}{ Religion } \\
\hline Catholic & $41 \%$ & $15 \%$ & $4 \%$ & $14 \%$ & $2 \%$ & $8 \%$ & $1 \%$ & $13 \%$ \\
\hline Protestant & $36 \%$ & $13 \%$ & $4 \%$ & $12 \%$ & $3 \%$ & $13 \%$ & $3 \%$ & $14 \%$ \\
\hline Muslim & $20 \%$ & $54 \%$ & $3 \%$ & $9 \%$ & $1 \%$ & $12 \%$ & $0 \%$ & $0 \%$ \\
\hline $\begin{array}{l}\text { Location } \\
\text { Urban }\end{array}$ & $40 \%$ & $15 \%$ & $4 \%$ & $12 \%$ & $2 \%$ & $9 \%$ & $1 \%$ & $14 \%$ \\
\hline Rural & $39 \%$ & $17 \%$ & $4 \%$ & $16 \%$ & $2 \%$ & $9 \%$ & $1 \%$ & $10 \%$ \\
\hline \multicolumn{9}{|l|}{ Age } \\
\hline $20-40$ & $42 \%$ & $15 \%$ & $5 \%$ & $15 \%$ & $2 \%$ & $4 \%$ & $1 \%$ & $14 \%$ \\
\hline $40-60$ & $37 \%$ & $17 \%$ & $3 \%$ & $13 \%$ & $2 \%$ & $15 \%$ & $2 \%$ & $9 \%$ \\
\hline $60+$ & $39 \%$ & $17 \%$ & $2 \%$ & $11 \%$ & $1 \%$ & $13 \%$ & $1 \%$ & $14 \%$ \\
\hline \multicolumn{9}{|l|}{ Gender } \\
\hline Woman & $41 \%$ & $13 \%$ & $4 \%$ & $15 \%$ & $2 \%$ & $9 \%$ & $1 \%$ & $14 \%$ \\
\hline Man & $39 \%$ & $19 \%$ & $4 \%$ & $13 \%$ & $2 \%$ & $8 \%$ & $2 \%$ & $11 \%$ \\
\hline
\end{tabular}




\begin{tabular}{|c|c|c|c|c|c|}
\hline \multicolumn{6}{|c|}{ Table BA4 - Structure of the vote in 2004} \\
\hline & KNP & Lakas & Aksyon & BPP & Laban \\
\hline \multicolumn{6}{|l|}{ Education } \\
\hline Primary & $44 \%$ & $43 \%$ & $5 \%$ & $3 \%$ & $6 \%$ \\
\hline Secondary & $32 \%$ & $39 \%$ & $4 \%$ & $8 \%$ & $17 \%$ \\
\hline Tertiary & $17 \%$ & $30 \%$ & $20 \%$ & $16 \%$ & $17 \%$ \\
\hline \multicolumn{6}{|l|}{ Income } \\
\hline Bottom 50\% & $39 \%$ & $48 \%$ & $4 \%$ & $2 \%$ & $7 \%$ \\
\hline Middle 40\% & $36 \%$ & $32 \%$ & $7 \%$ & $9 \%$ & $16 \%$ \\
\hline Top 10\% & $22 \%$ & $33 \%$ & $7 \%$ & $19 \%$ & $19 \%$ \\
\hline \multicolumn{6}{|l|}{ Ethnicity } \\
\hline Bicolano & $19 \%$ & $22 \%$ & $30 \%$ & $11 \%$ & $18 \%$ \\
\hline Ilocano & $49 \%$ & $25 \%$ & $4 \%$ & $10 \%$ & $12 \%$ \\
\hline Ilonggo & $28 \%$ & $50 \%$ & $2 \%$ & $5 \%$ & $15 \%$ \\
\hline Other & $32 \%$ & $58 \%$ & $4 \%$ & $2 \%$ & $4 \%$ \\
\hline Tagalog & $42 \%$ & $24 \%$ & $9 \%$ & $11 \%$ & $14 \%$ \\
\hline Visaya & $32 \%$ & $56 \%$ & $2 \%$ & $2 \%$ & $7 \%$ \\
\hline Waray & $49 \%$ & $33 \%$ & $8 \%$ & $2 \%$ & $7 \%$ \\
\hline \multicolumn{6}{|l|}{ Region } \\
\hline NCR & $36 \%$ & $25 \%$ & $9 \%$ & $14 \%$ & $17 \%$ \\
\hline Luzon & $44 \%$ & $28 \%$ & $11 \%$ & $6 \%$ & $11 \%$ \\
\hline Visayas & $20 \%$ & $67 \%$ & $4 \%$ & $5 \%$ & $4 \%$ \\
\hline Mindanao & $44 \%$ & $43 \%$ & $2 \%$ & $1 \%$ & $10 \%$ \\
\hline \multicolumn{6}{|l|}{ Religion } \\
\hline Catholic & $36 \%$ & $39 \%$ & $7 \%$ & $6 \%$ & $12 \%$ \\
\hline Protestant & $36 \%$ & $45 \%$ & $2 \%$ & $12 \%$ & $5 \%$ \\
\hline Muslim & $51 \%$ & $49 \%$ & $0 \%$ & $0 \%$ & $0 \%$ \\
\hline \multicolumn{6}{|l|}{ Location } \\
\hline Urban & $35 \%$ & $27 \%$ & $11 \%$ & $12 \%$ & $16 \%$ \\
\hline Rural & $38 \%$ & $47 \%$ & $4 \%$ & $3 \%$ & $8 \%$ \\
\hline \multicolumn{6}{|l|}{ Age } \\
\hline $20-40$ & $36 \%$ & $38 \%$ & $8 \%$ & $5 \%$ & $13 \%$ \\
\hline $40-60$ & $38 \%$ & $39 \%$ & $6 \%$ & $8 \%$ & $10 \%$ \\
\hline $60+$ & $36 \%$ & $50 \%$ & $3 \%$ & $4 \%$ & $7 \%$ \\
\hline \multicolumn{6}{|l|}{ Gender } \\
\hline Woman & $36 \%$ & $42 \%$ & $6 \%$ & $7 \%$ & $10 \%$ \\
\hline Man & $37 \%$ & $38 \%$ & $7 \%$ & $5 \%$ & $12 \%$ \\
\hline
\end{tabular}




\begin{tabular}{|c|c|c|c|c|}
\hline \multicolumn{5}{|c|}{ Table BA5 - Structure of the vote in 2010} \\
\hline & Liberal & PMP & Lakas & Nacionalista \\
\hline \multicolumn{5}{|l|}{ Education } \\
\hline Primary & $45 \%$ & $32 \%$ & $4 \%$ & $16 \%$ \\
\hline Secondary & $41 \%$ & $26 \%$ & $12 \%$ & $14 \%$ \\
\hline Tertiary & $36 \%$ & $14 \%$ & $28 \%$ & $16 \%$ \\
\hline \multicolumn{5}{|l|}{ Income } \\
\hline Bottom 50\% & $44 \%$ & $29 \%$ & $7 \%$ & $18 \%$ \\
\hline Middle 40\% & $39 \%$ & $25 \%$ & $16 \%$ & $14 \%$ \\
\hline Top 10\% & $38 \%$ & $23 \%$ & $18 \%$ & $16 \%$ \\
\hline \multicolumn{5}{|l|}{ Ethnicity } \\
\hline Bicolano & $46 \%$ & $29 \%$ & $9 \%$ & $10 \%$ \\
\hline Ilocano & $38 \%$ & $39 \%$ & $2 \%$ & $18 \%$ \\
\hline Ilonggo & $39 \%$ & $26 \%$ & $11 \%$ & $17 \%$ \\
\hline Other & $50 \%$ & $13 \%$ & $24 \%$ & $14 \%$ \\
\hline Tagalog & $40 \%$ & $33 \%$ & $9 \%$ & $11 \%$ \\
\hline Visaya & $42 \%$ & $16 \%$ & $13 \%$ & $23 \%$ \\
\hline Waray & $41 \%$ & $52 \%$ & $0 \%$ & $7 \%$ \\
\hline \multicolumn{5}{|l|}{ Region } \\
\hline NCR & $35 \%$ & $30 \%$ & $12 \%$ & $12 \%$ \\
\hline Luzon & $43 \%$ & $29 \%$ & $12 \%$ & $12 \%$ \\
\hline Visayas & $50 \%$ & $20 \%$ & $11 \%$ & $14 \%$ \\
\hline Mindanao & $38 \%$ & $24 \%$ & $11 \%$ & $23 \%$ \\
\hline \multicolumn{5}{|l|}{ Religion } \\
\hline Catholic & $41 \%$ & $27 \%$ & $11 \%$ & $16 \%$ \\
\hline Protestant & $44 \%$ & $24 \%$ & $4 \%$ & $15 \%$ \\
\hline Muslim & $61 \%$ & $6 \%$ & $20 \%$ & $13 \%$ \\
\hline \multicolumn{5}{|l|}{ Location } \\
\hline Urban & $41 \%$ & $24 \%$ & $14 \%$ & $16 \%$ \\
\hline Rural & $44 \%$ & $29 \%$ & $9 \%$ & $15 \%$ \\
\hline \multicolumn{5}{|l|}{ Age } \\
\hline $20-40$ & $39 \%$ & $25 \%$ & $11 \%$ & $17 \%$ \\
\hline $40-60$ & $43 \%$ & $28 \%$ & $12 \%$ & $15 \%$ \\
\hline $60+$ & $50 \%$ & $25 \%$ & $10 \%$ & $12 \%$ \\
\hline \multicolumn{5}{|l|}{ Gender } \\
\hline Woman & $42 \%$ & $24 \%$ & $12 \%$ & $17 \%$ \\
\hline Man & $43 \%$ & $28 \%$ & $10 \%$ & $14 \%$ \\
\hline
\end{tabular}




\begin{tabular}{|c|c|c|c|c|}
\hline \multicolumn{5}{|c|}{ Table BA6 - Detailed structure of the vote in 2016} \\
\hline & Duterte & Roxas & Poe & Binay \\
\hline Overall vote share & $39 \%$ & $24 \%$ & $21 \%$ & $13 \%$ \\
\hline \multicolumn{5}{|l|}{ Education } \\
\hline Primary & $42 \%$ & $24 \%$ & $19 \%$ & $13 \%$ \\
\hline Secondary & $35 \%$ & $24 \%$ & $24 \%$ & $12 \%$ \\
\hline Tertiary & $43 \%$ & $21 \%$ & $21 \%$ & $12 \%$ \\
\hline \multicolumn{5}{|l|}{ Income } \\
\hline Bottom 50\% & $37 \%$ & $26 \%$ & $22 \%$ & $13 \%$ \\
\hline Middle $40 \%$ & $41 \%$ & $21 \%$ & $21 \%$ & $12 \%$ \\
\hline Top $10 \%$ & $39 \%$ & $25 \%$ & $20 \%$ & $11 \%$ \\
\hline \multicolumn{5}{|l|}{ Ethnicity } \\
\hline Bicolano & $15 \%$ & $45 \%$ & $25 \%$ & $11 \%$ \\
\hline Ilocano & $29 \%$ & $15 \%$ & $30 \%$ & $22 \%$ \\
\hline Ilonggo & $42 \%$ & $15 \%$ & $29 \%$ & $4 \%$ \\
\hline Other & $42 \%$ & $19 \%$ & $16 \%$ & $18 \%$ \\
\hline Tagalog & $35 \%$ & $19 \%$ & $28 \%$ & $17 \%$ \\
\hline Visaya & $53 \%$ & $29 \%$ & $15 \%$ & $3 \%$ \\
\hline Waray & $44 \%$ & $12 \%$ & $18 \%$ & $16 \%$ \\
\hline \multicolumn{5}{|l|}{ Region } \\
\hline NCR & $33 \%$ & $16 \%$ & $27 \%$ & $19 \%$ \\
\hline Luzon & $29 \%$ & $26 \%$ & $27 \%$ & $16 \%$ \\
\hline Visayas & $39 \%$ & $31 \%$ & $17 \%$ & $8 \%$ \\
\hline Mindanao & $62 \%$ & $16 \%$ & $12 \%$ & $7 \%$ \\
\hline \multicolumn{5}{|l|}{ Religion } \\
\hline Catholic & $37 \%$ & $25 \%$ & $22 \%$ & $12 \%$ \\
\hline Protestant & $31 \%$ & $21 \%$ & $30 \%$ & $18 \%$ \\
\hline Muslim & $75 \%$ & $5 \%$ & $3 \%$ & $13 \%$ \\
\hline \multicolumn{5}{|l|}{ Location } \\
\hline Urban & $43 \%$ & $15 \%$ & $21 \%$ & $15 \%$ \\
\hline Rural & $36 \%$ & $30 \%$ & $22 \%$ & $11 \%$ \\
\hline \multicolumn{5}{|l|}{ Age } \\
\hline $20-40$ & $44 \%$ & $21 \%$ & $20 \%$ & $11 \%$ \\
\hline $40-60$ & $36 \%$ & $21 \%$ & $26 \%$ & $13 \%$ \\
\hline $60+$ & $35 \%$ & $34 \%$ & $12 \%$ & $16 \%$ \\
\hline \multicolumn{5}{|l|}{ Gender } \\
\hline Woman & $34 \%$ & $28 \%$ & $23 \%$ & $12 \%$ \\
\hline Man & $45 \%$ & $19 \%$ & $20 \%$ & $14 \%$ \\
\hline \multicolumn{5}{|l|}{ Occupation } \\
\hline Farmer & $49 \%$ & $25 \%$ & $12 \%$ & $8 \%$ \\
\hline Self-Employed & $39 \%$ & $26 \%$ & $17 \%$ & $16 \%$ \\
\hline White Collar & $32 \%$ & $29 \%$ & $24 \%$ & $10 \%$ \\
\hline Worker & $39 \%$ & $17 \%$ & $27 \%$ & $14 \%$ \\
\hline
\end{tabular}


Source: authors' computations using Filipino political attitudes surveys.

Notes: the table shows the vote share received by main parties among specific groups of the Filipino voting population in the 2016 election. 
Table BA7 - Determinants of the vote for main candidates in the

2016 Filipino presidential election

\begin{tabular}{|c|c|c|c|c|}
\hline & $\begin{array}{c}(1) \\
\text { Duterte }\end{array}$ & $\begin{array}{c}(2) \\
\text { Roxas } \\
\end{array}$ & $\begin{array}{c}(3) \\
\text { Poe } \\
\end{array}$ & $\begin{array}{c}(4) \\
\text { Binay }\end{array}$ \\
\hline Education: Primary & $\begin{array}{c}\text { (baseline) } \\
\text { (.) }\end{array}$ & $\begin{array}{c}\text { (baseline) } \\
(.)\end{array}$ & $\begin{array}{c}\text { (baseline) } \\
(.)\end{array}$ & $\begin{array}{c}\text { (baseline) } \\
(.)\end{array}$ \\
\hline Education: Secondary & $\begin{array}{c}-0.058^{* *} \\
(0.024)\end{array}$ & $\begin{array}{c}0.036 \\
(0.026)\end{array}$ & $\begin{array}{c}0.030 \\
(0.028)\end{array}$ & $\begin{array}{l}-0.015 \\
(0.019)\end{array}$ \\
\hline Education: Tertiary & $\begin{array}{c}0.002 \\
(0.035)\end{array}$ & $\begin{array}{c}0.034 \\
(0.038)\end{array}$ & $\begin{array}{c}-0.002 \\
(0.039)\end{array}$ & $\begin{array}{c}-0.028 \\
(0.029)\end{array}$ \\
\hline Income: Bottom 50\% & $\begin{array}{c}\text { (baseline) } \\
(.)\end{array}$ & $\begin{array}{c}\text { (baseline) } \\
(.)\end{array}$ & $\begin{array}{c}\text { (baseline) } \\
(.)\end{array}$ & $\begin{array}{c}\text { (baseline) } \\
(.)\end{array}$ \\
\hline Income: Middle $40 \%$ & $\begin{array}{c}0.043^{*} \\
(0.023)\end{array}$ & $\begin{array}{l}-0.012 \\
(0.025)\end{array}$ & $\begin{array}{l}-0.037 \\
(0.027)\end{array}$ & $\begin{array}{l}-0.021 \\
(0.019)\end{array}$ \\
\hline Income: Top 10\% & $\begin{array}{c}0.036 \\
(0.044)\end{array}$ & $\begin{array}{c}0.048 \\
(0.047)\end{array}$ & $\begin{array}{l}-0.057 \\
(0.046)\end{array}$ & $\begin{array}{c}-0.044 \\
(0.033)\end{array}$ \\
\hline Age: 20-39 & $\begin{array}{c}\text { (baseline) } \\
\text { (.) }\end{array}$ & $\begin{array}{c}\text { (baseline) } \\
(.)\end{array}$ & $\begin{array}{c}\text { (baseline) } \\
(.)\end{array}$ & $\begin{array}{c}\text { (baseline) } \\
(.)\end{array}$ \\
\hline Age: $40-59$ & $\begin{array}{c}-0.088^{* * *} \\
(0.023)\end{array}$ & $\begin{array}{c}0.012 \\
(0.025)\end{array}$ & $\begin{array}{l}0.061^{\star *} \\
(0.027)\end{array}$ & $\begin{array}{c}0.018 \\
(0.018)\end{array}$ \\
\hline Age: $60+$ & $\begin{array}{c}-0.103^{* * *} \\
(0.031)\end{array}$ & $\begin{array}{c}0.130^{* * *} \\
(0.037)\end{array}$ & $\begin{array}{c}-0.070^{* *} \\
(0.031)\end{array}$ & $\begin{array}{l}0.049^{*} \\
(0.026)\end{array}$ \\
\hline Gender: Man & $\begin{array}{c}0.101^{* * *} \\
(0.021)\end{array}$ & $\begin{array}{c}-0.084^{\star \star \star} \\
(0.023)\end{array}$ & $\begin{array}{c}-0.033 \\
(0.024)\end{array}$ & $\begin{array}{c}0.011 \\
(0.017)\end{array}$ \\
\hline Ethnicity: Bicolano & $\begin{array}{c}-0.158^{\star * *} \\
(0.037)\end{array}$ & $\begin{array}{c}0.184^{\star \star \star} \\
(0.055)\end{array}$ & $\begin{array}{c}-0.032 \\
(0.054)\end{array}$ & $\begin{array}{l}-0.047 \\
(0.035)\end{array}$ \\
\hline Ethnicity: Ilocano & $\begin{array}{l}-0.070 \\
(0.045)\end{array}$ & $\begin{array}{l}-0.056 \\
(0.046)\end{array}$ & $\begin{array}{c}0.021 \\
(0.055)\end{array}$ & $\begin{array}{c}0.079^{*} \\
(0.045)\end{array}$ \\
\hline Ethnicity: Ilonggo & $\begin{array}{c}-0.068 \\
(0.058)\end{array}$ & $\begin{array}{l}-0.035 \\
(0.052)\end{array}$ & $\begin{array}{c}0.109 \\
(0.067)\end{array}$ & $\begin{array}{c}-0.083^{\star *} \\
(0.034)\end{array}$ \\
\hline Ethnicity: Other & -0.018 & -0.020 & -0.062 & 0.062 \\
\hline
\end{tabular}




\begin{tabular}{|c|c|c|c|c|}
\hline \multirow{3}{*}{ Ethnicity: Tagalog } & $(0.042)$ & $(0.040)$ & $(0.044)$ & $(0.039)$ \\
\hline & (baseline) & (baseline) & (baseline) & (baseline) \\
\hline & $()$. & (.) & $()$. & $()$. \\
\hline \multirow[t]{2}{*}{ Ethnicity: Visaya } & 0.044 & $0.091^{* *}$ & -0.031 & $-0.081^{* *}$ \\
\hline & $(0.043)$ & $(0.042)$ & $(0.051)$ & $(0.032)$ \\
\hline \multirow[t]{2}{*}{ Ethnicity: Waray } & 0.055 & $-0.110^{\star *}$ & -0.022 & 0.026 \\
\hline & $(0.061)$ & $(0.055)$ & $(0.061)$ & $(0.044)$ \\
\hline \multirow[t]{2}{*}{ Region: NCR } & (baseline) & (baseline) & (baseline) & (baseline) \\
\hline & $()$. & $()$. & (.) & $()$. \\
\hline \multirow[t]{2}{*}{ Region: Luzon } & 0.046 & 0.014 & -0.022 & -0.032 \\
\hline & $(0.034)$ & $(0.033)$ & $(0.037)$ & $(0.030)$ \\
\hline \multirow[t]{2}{*}{ Region: Visayas } & $0.074^{*}$ & 0.070 & $-0.101^{* *}$ & $-0.084^{\star \star *}$ \\
\hline & $(0.043)$ & $(0.046)$ & $(0.049)$ & $(0.032)$ \\
\hline \multirow[t]{2}{*}{ Region: Mindanao } & $0.312^{\star * \star}$ & $-0.091^{* *}$ & $-0.167^{\star \star *}$ & $-0.077^{* *}$ \\
\hline & $(0.042)$ & $(0.041)$ & $(0.045)$ & $(0.032)$ \\
\hline \multirow[t]{2}{*}{ Location: Rural area } & $-0.065^{\star *}$ & $0.119^{* * *}$ & 0.023 & -0.031 \\
\hline & $(0.026)$ & $(0.026)$ & $(0.028)$ & $(0.021)$ \\
\hline \multicolumn{2}{|l|}{ Constant } & $0.132^{\star * \star}$ & $0.296^{\star * *}$ & $0.203^{* \star *}$ \\
\hline \multicolumn{5}{|c|}{$\begin{array}{l}\text { Source: authors' computations based on Filipino surveys. } \\
\text { Note: the table shows the results of a multivariate regression assessing the determinants of support for the main candidates of the } \\
2016 \text { presidential election. All other things equal, voters aged } 60 \text { or older were significantly less likely to support Duterte than those } \\
\text { being younger than } 40 \text { years old. }\end{array}$} \\
\hline
\end{tabular}


Figure CA1 - General election results by group, 1955-2018

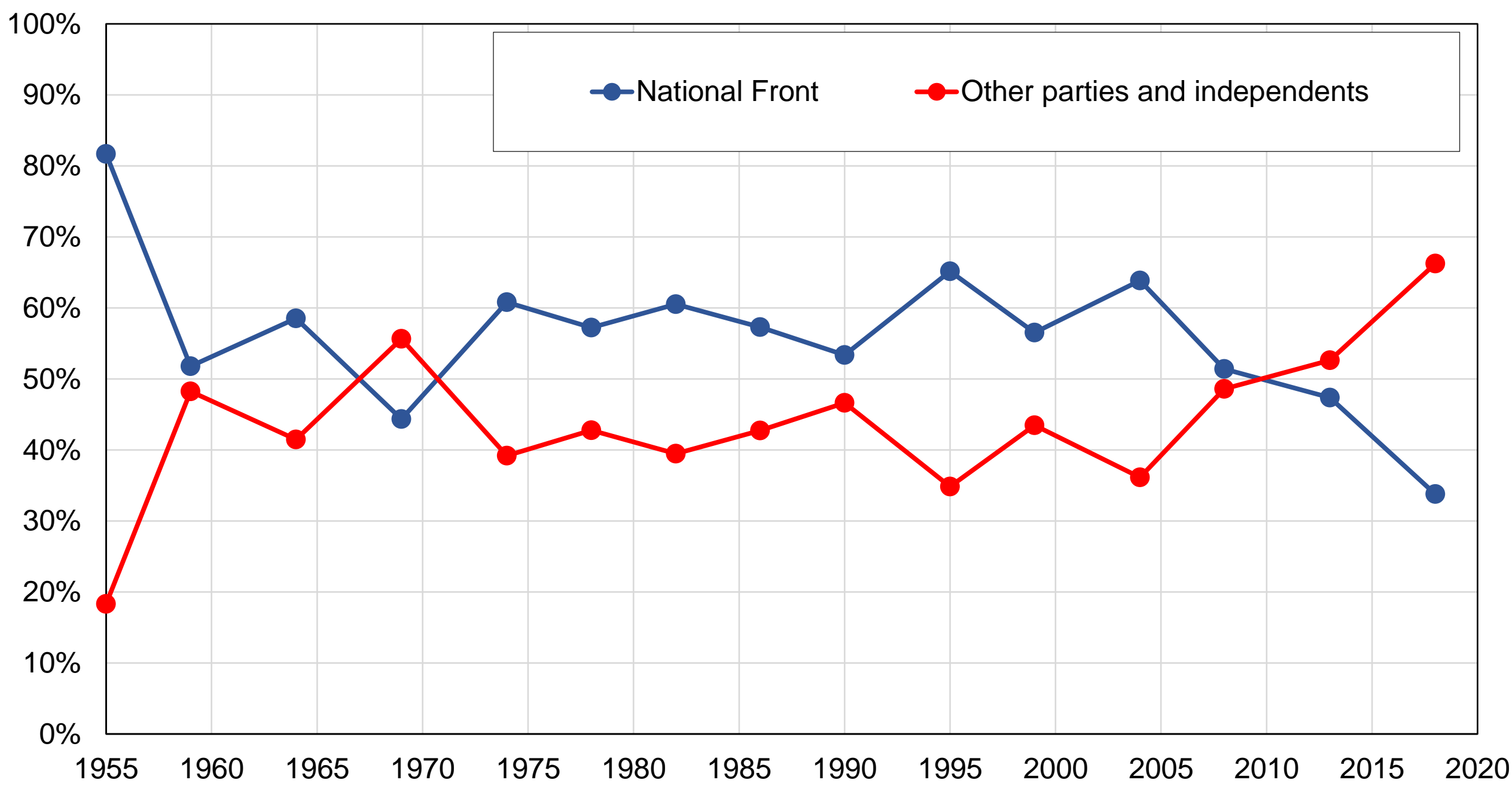

Source: authors' computations using official election results.

Note: the figure shows the vote shares received by selected groups of parties in general elections. 
Figure CA2 - Composition of the electorate by religious affiliation

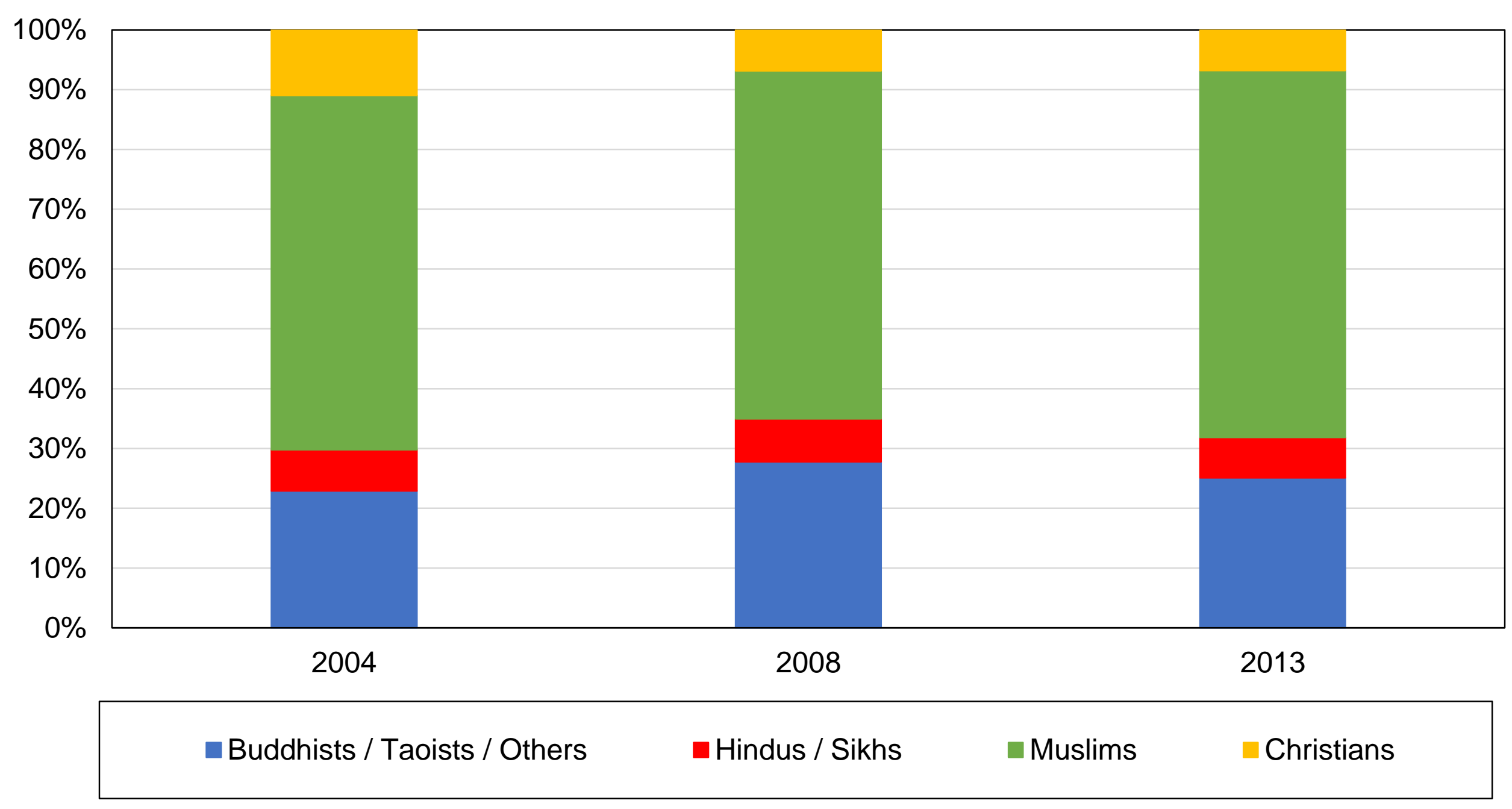

Source: authors' computations using Asian Barometer surveys.

Note: the figure shows the composition of the electorate by religion. 
Figure CA3 - Composition of the electorate by education

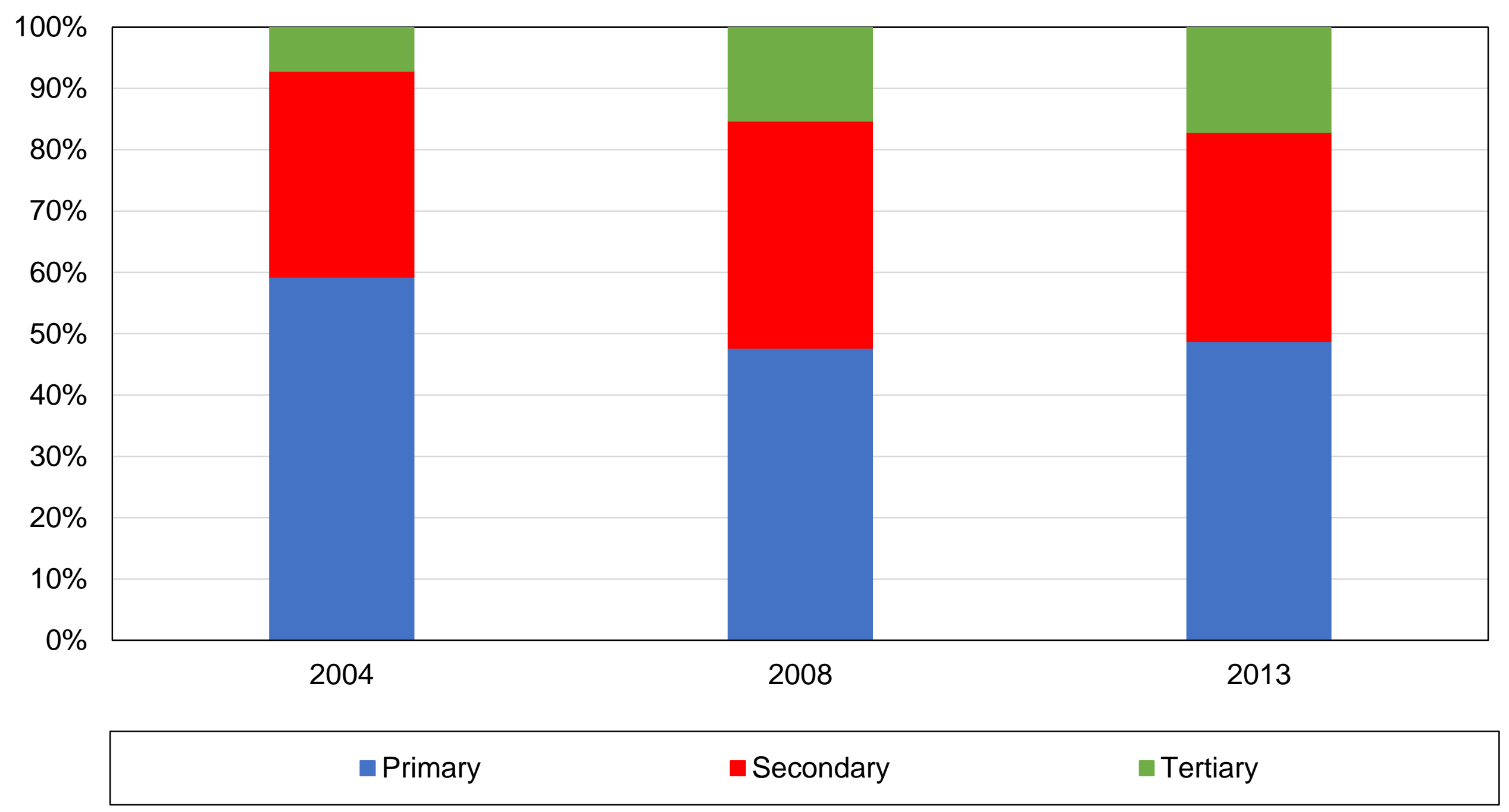

Source: authors' computations using Asian Barometer surveys.

Note: the figure shows the composition of the electorate by education level. 
Figure CA4 - Composition of the electorate by age group

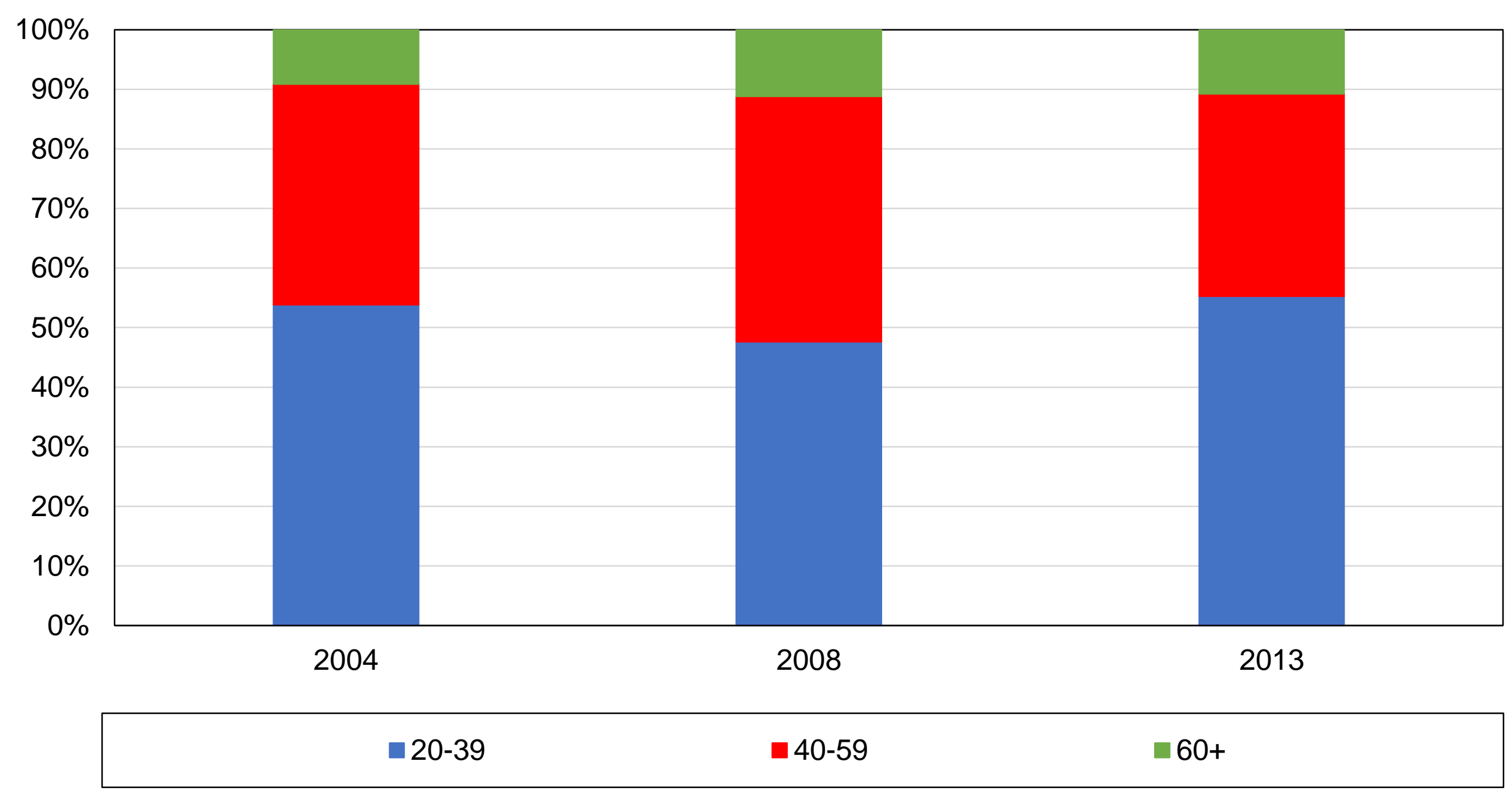

Source: authors' computations using Asian Barometer surveys.

Note: the figure shows the composition of the electorate by age group. 
Figure CA5 - Composition of income groups by religious affiliation

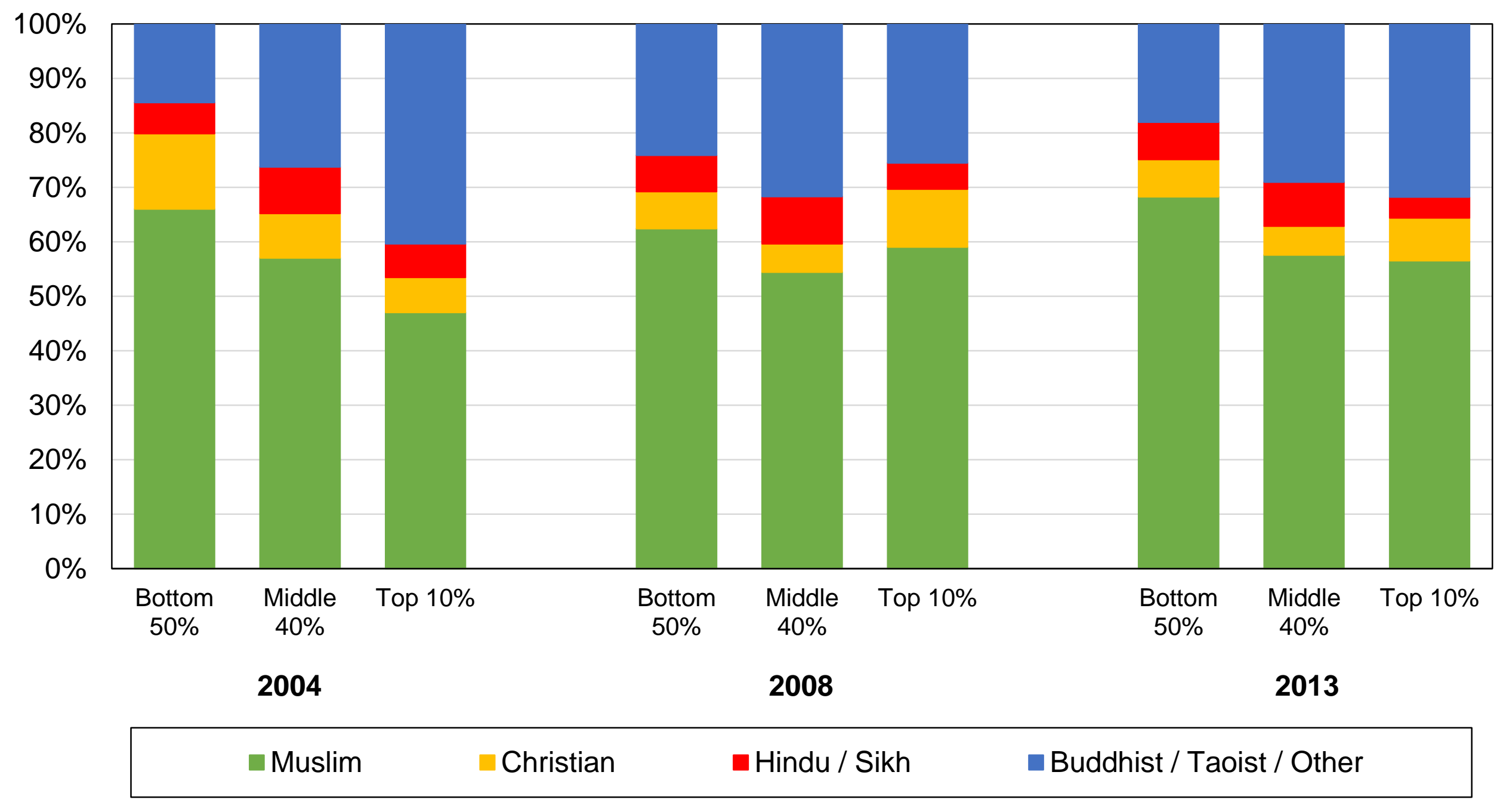

Source: authors' computations using Asian Barometer surveys.

Note: the figure shows the composition of income groups by religious affiliation. 


\section{Figure CB1 - Vote for the National Front coalition by education}

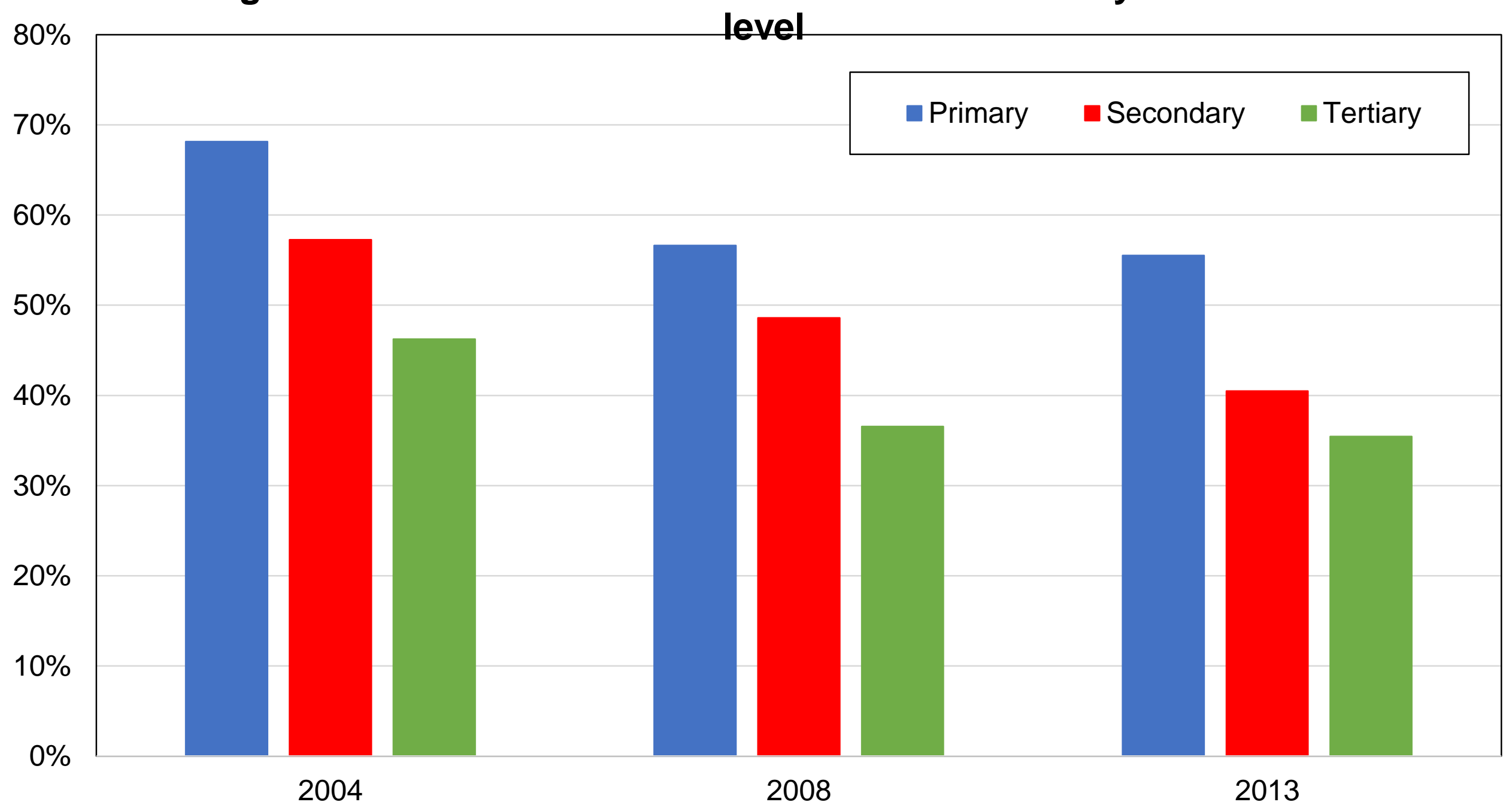

Source: authors' computations using Asian Barometer surveys.

Note: the figure shows the share of votes received by the National Front by education level. 
Figure CB2 - Vote for the National Front coalition by income

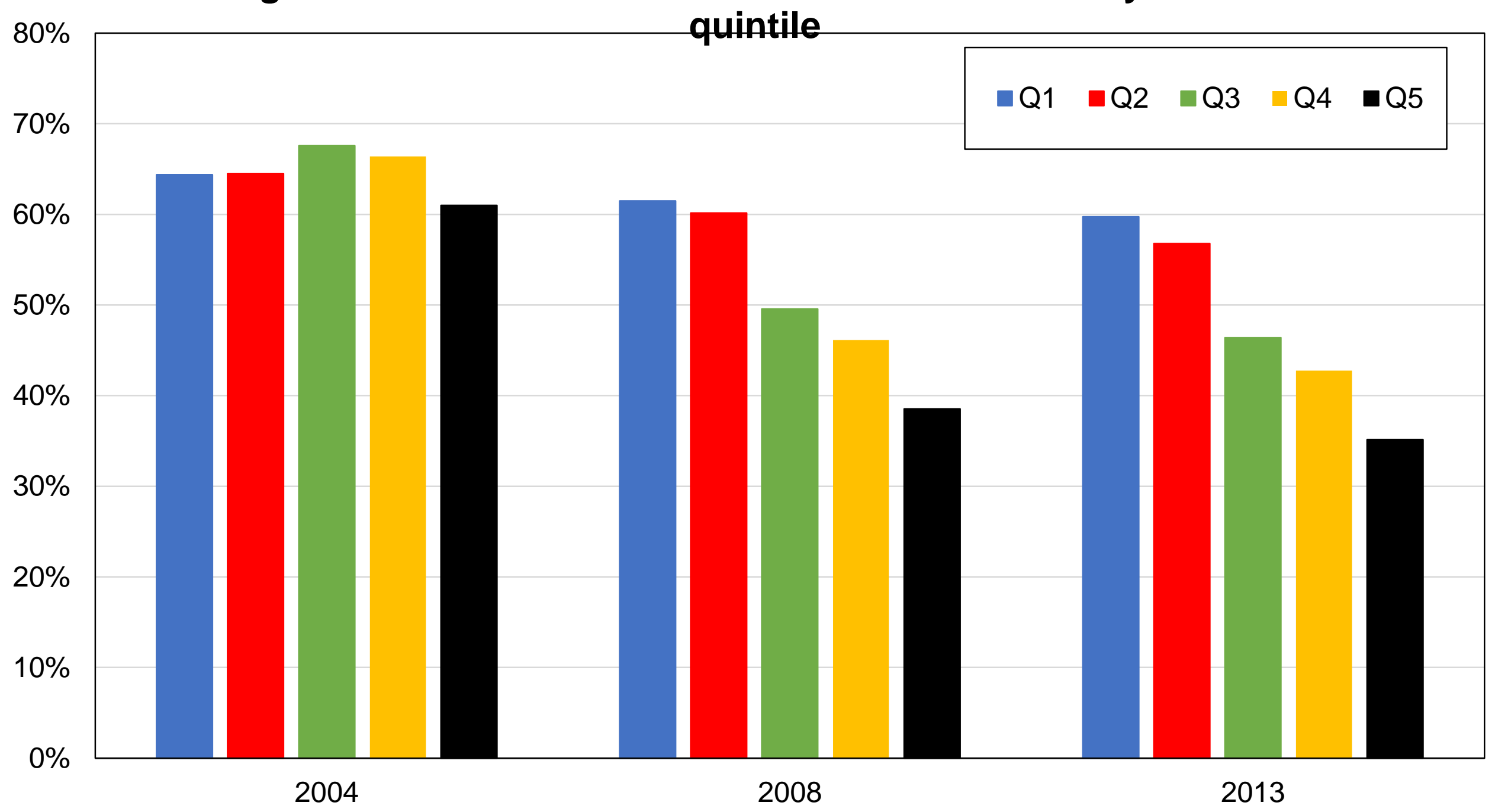

Source: authors' computations using Asian Barometer surveys.

Note: the figure shows the share of votes received by the National Front by income quintile. 
Figure CB3 - Vote for the National Front coalition by income group

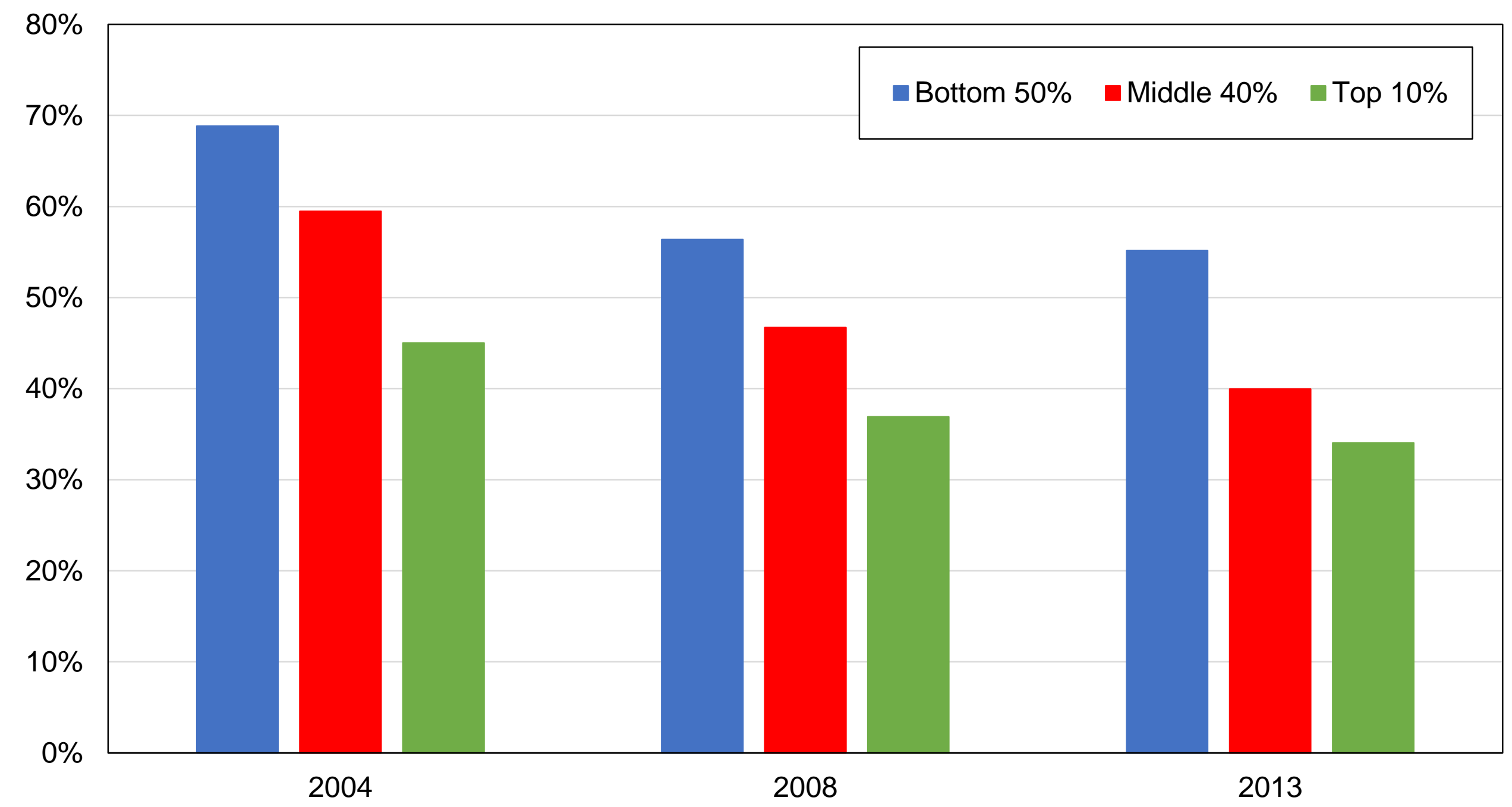

Source: authors' computations using Asian Barometer surveys.

Note: the figure shows the share of votes received by the National Front by income group. 
Figure CB4 - Vote for the National Front coalition by religion

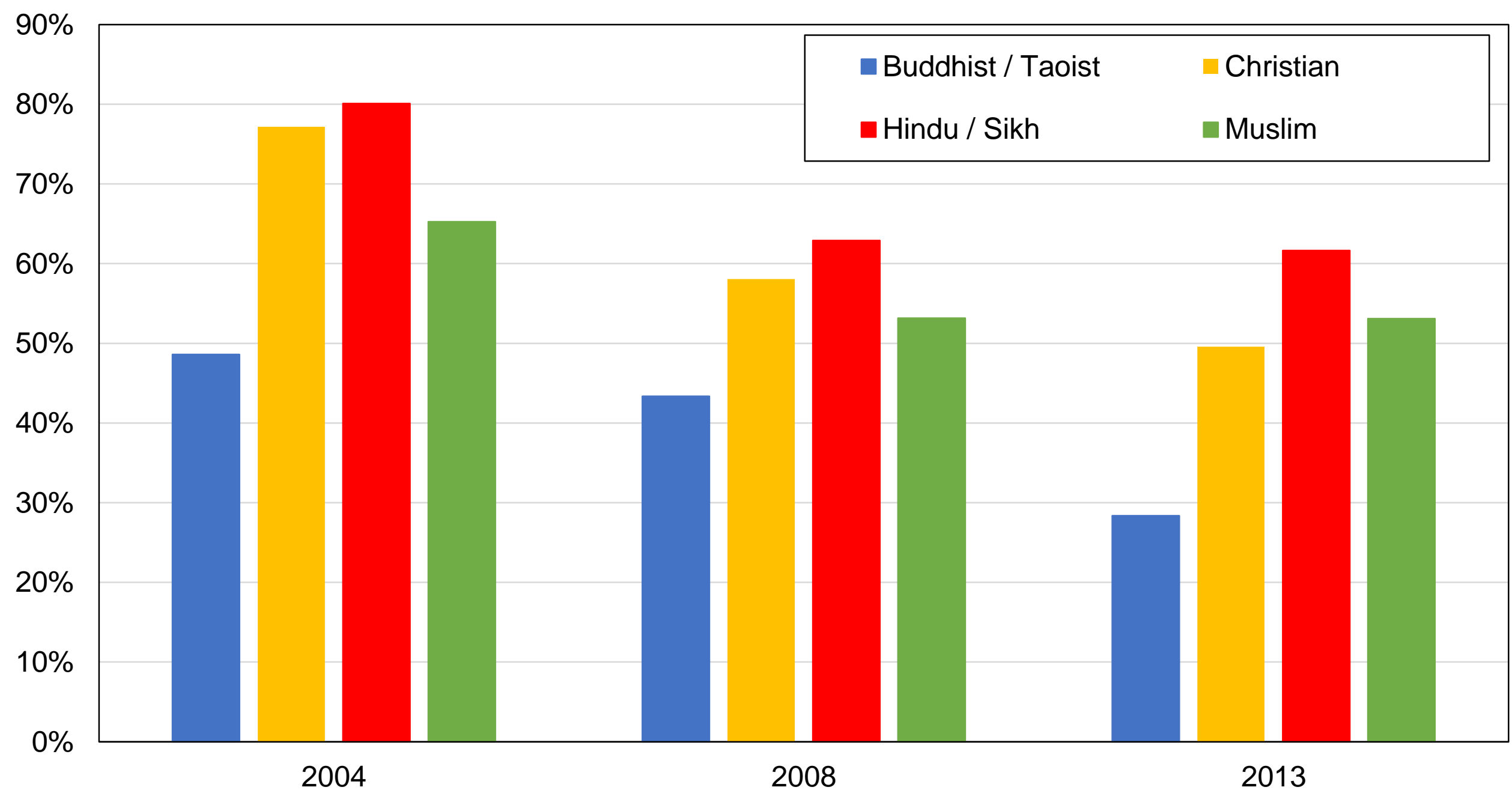

Source: authors' computations using Asian Barometer surveys.

Note: the figure shows the share of votes received by the National Front by religious affiliation. 


\section{Figure CB5 - Vote for the National Front coalition by location}

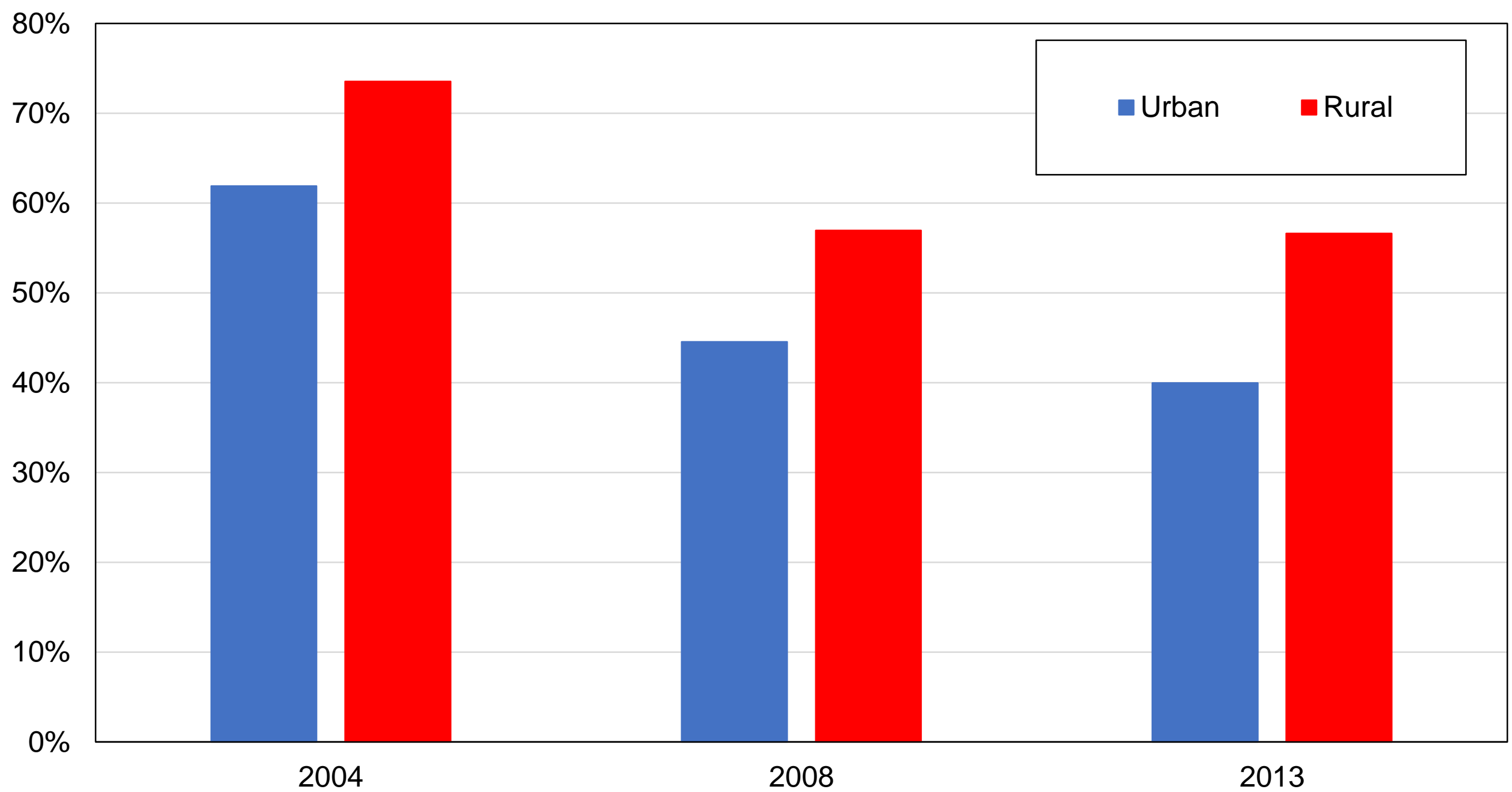

Source: authors' computations using Asian Barometer surveys.

Note: the figure shows the share of votes received by the National Front by rural-urban location. 
Figure CB6 - Vote for the National Front coalition by age group

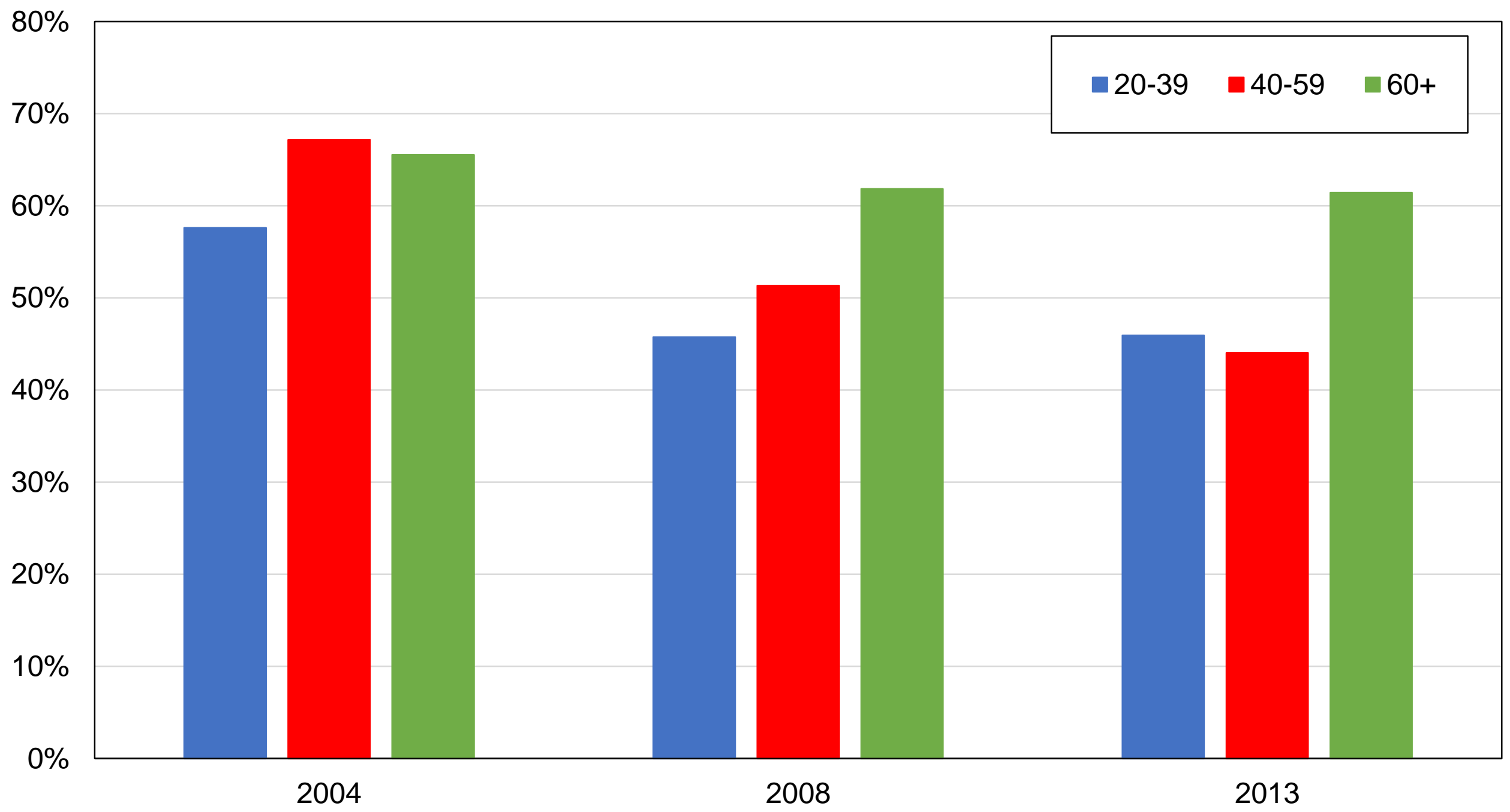

Source: authors' computations using Asian Barometer surveys.

Note: the figure shows the share of votes received by the National Front by age group. 
Figure CB7 - Vote for the National Front coalition by gender

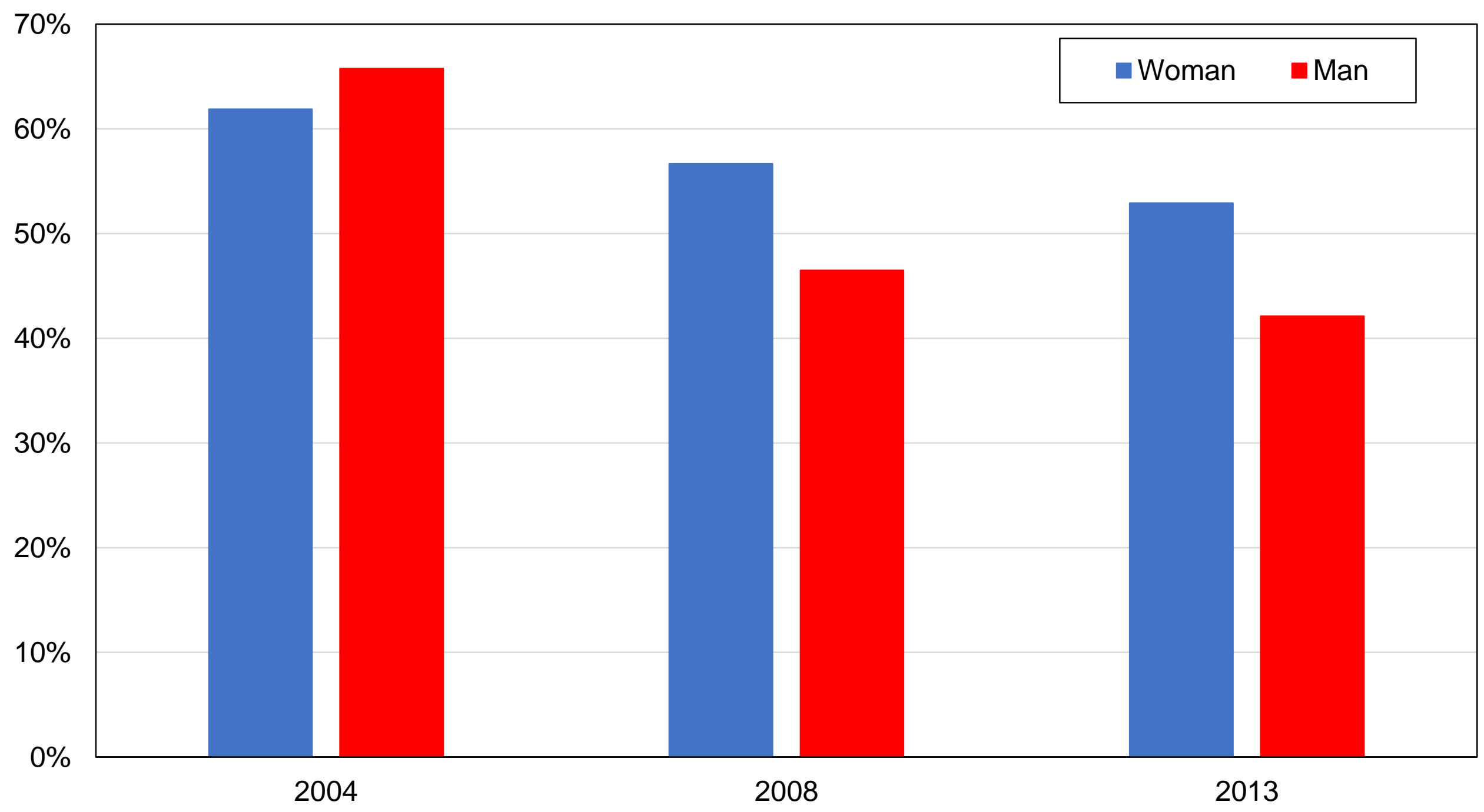

Source: authors' computations using Asian Barometer surveys.

Note: the figure shows the share of votes received by the National Front by gender. 


\section{Figure CC1 - Religious cleavages in Malaysia}

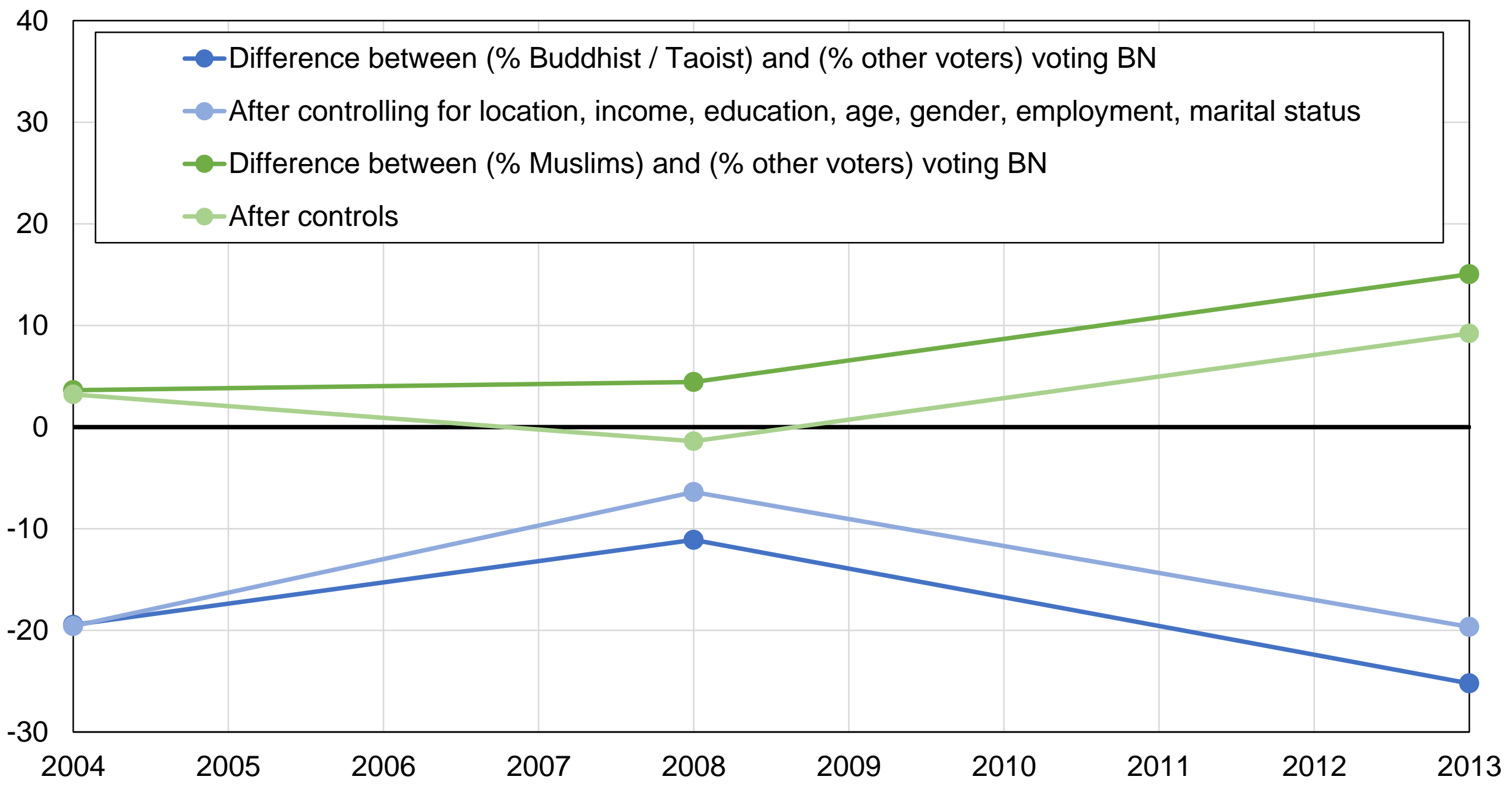

Source: authors' computations using Asian Barometer surveys.

Note: the figure shows the difference the share of Buddhists and Taoists voting for the National Front and the share of other voters voting for the National Front, before and after controls. 


\section{Figure CC2 - Support for the National Front Coalition among highest-educated voters}

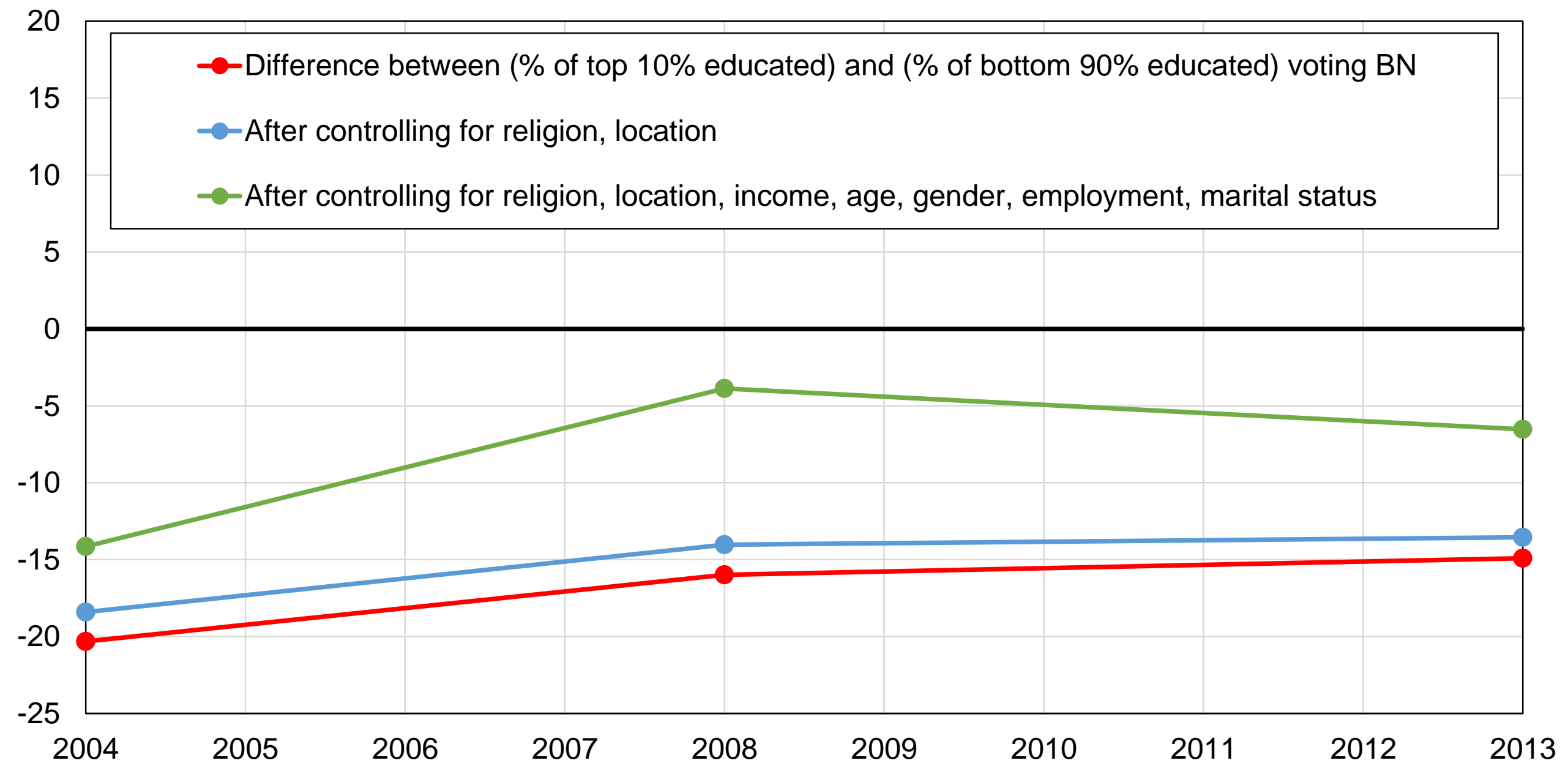

Source: authors' computations using Asian Barometer surveys.

Note: the figure shows the difference between the share of top $10 \%$ educated voters voting for the National Front and the share of bottom $90 \%$ educated voting for the National Front, before and after controls. 


\section{Figure CC3 - Support for the National Front Coalition among lowest-educated voters}

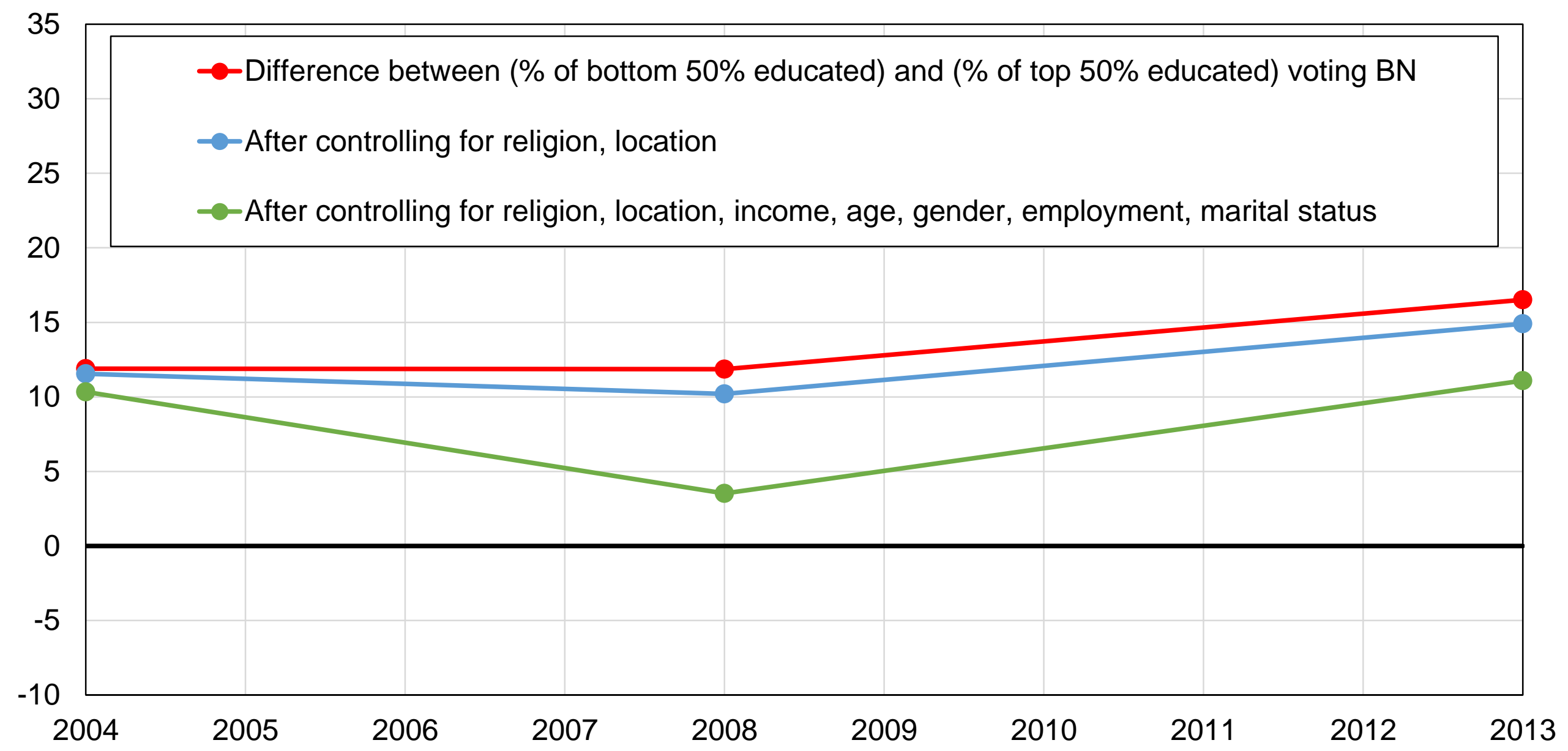

Source: authors' computations using Asian Barometer surveys.

Note: the figure shows the difference between the share of bottom $50 \%$ educated voters voting for the National Front and the share of top 50\% educated voters voting for the Barisan Nasional, before and after controls. 


\section{Figure CC4 - Support for the National Front Coalition among low-income voters}

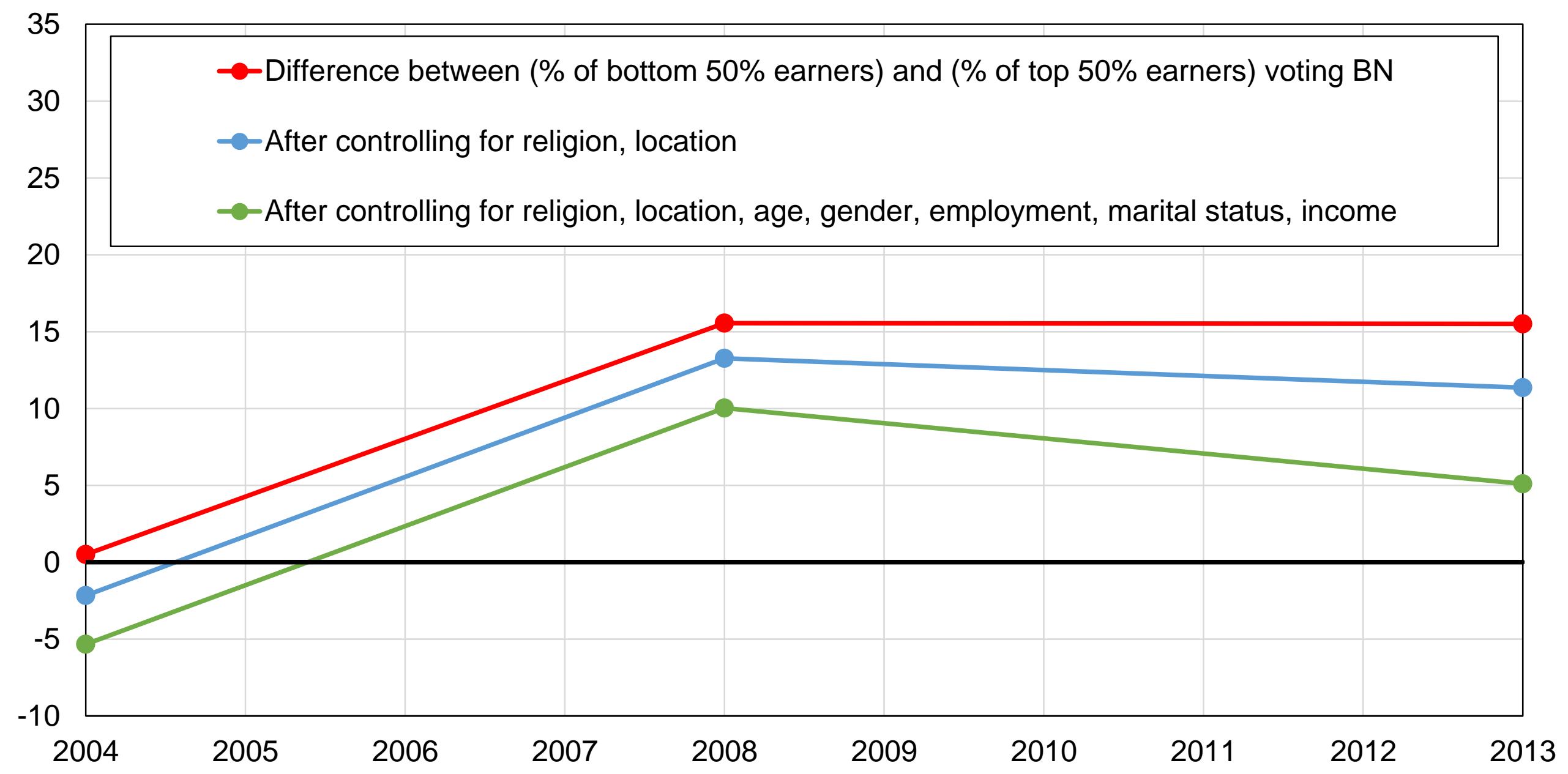

Source: authors' computations using Asian Barometer surveys.

Note: the figure shows the difference between the share of bottom $50 \%$ earners voting for the National Front and the share of top 50\% earners voting for the National Front, before and after controls. 


\section{Figure CC5 - Support for the National Front Coalition among top-income voters}

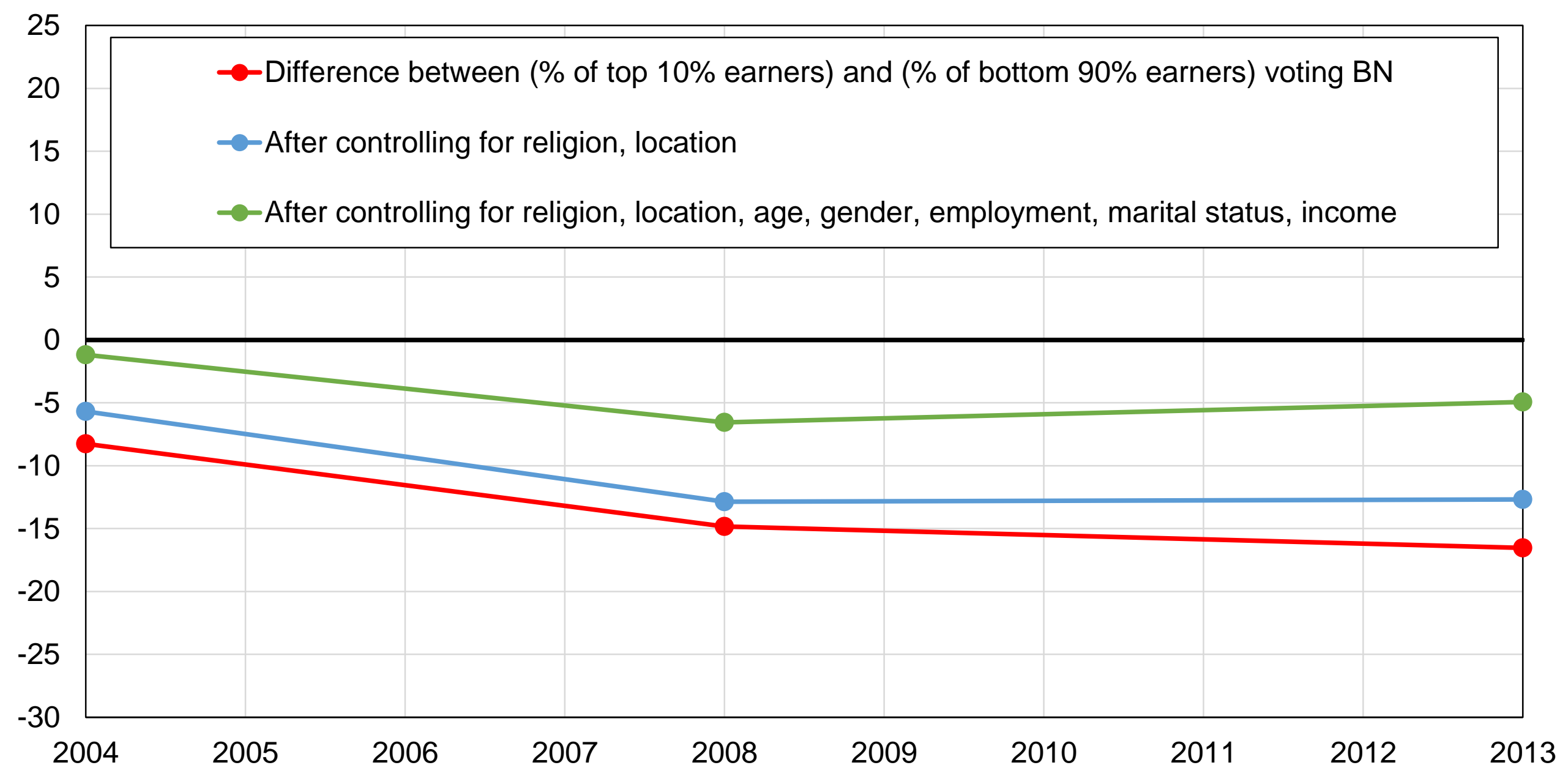

Source: authors' computations using Asian Barometer surveys.

Note: the figure shows the difference between the share of top $10 \%$ earners voting for the Barisan Nasional and the share of bottom $90 \%$ earners voting for the Barisan Nasional, before and after controls. 


\section{Figure CC6 - Support for the National Front Coalition among rural areas}

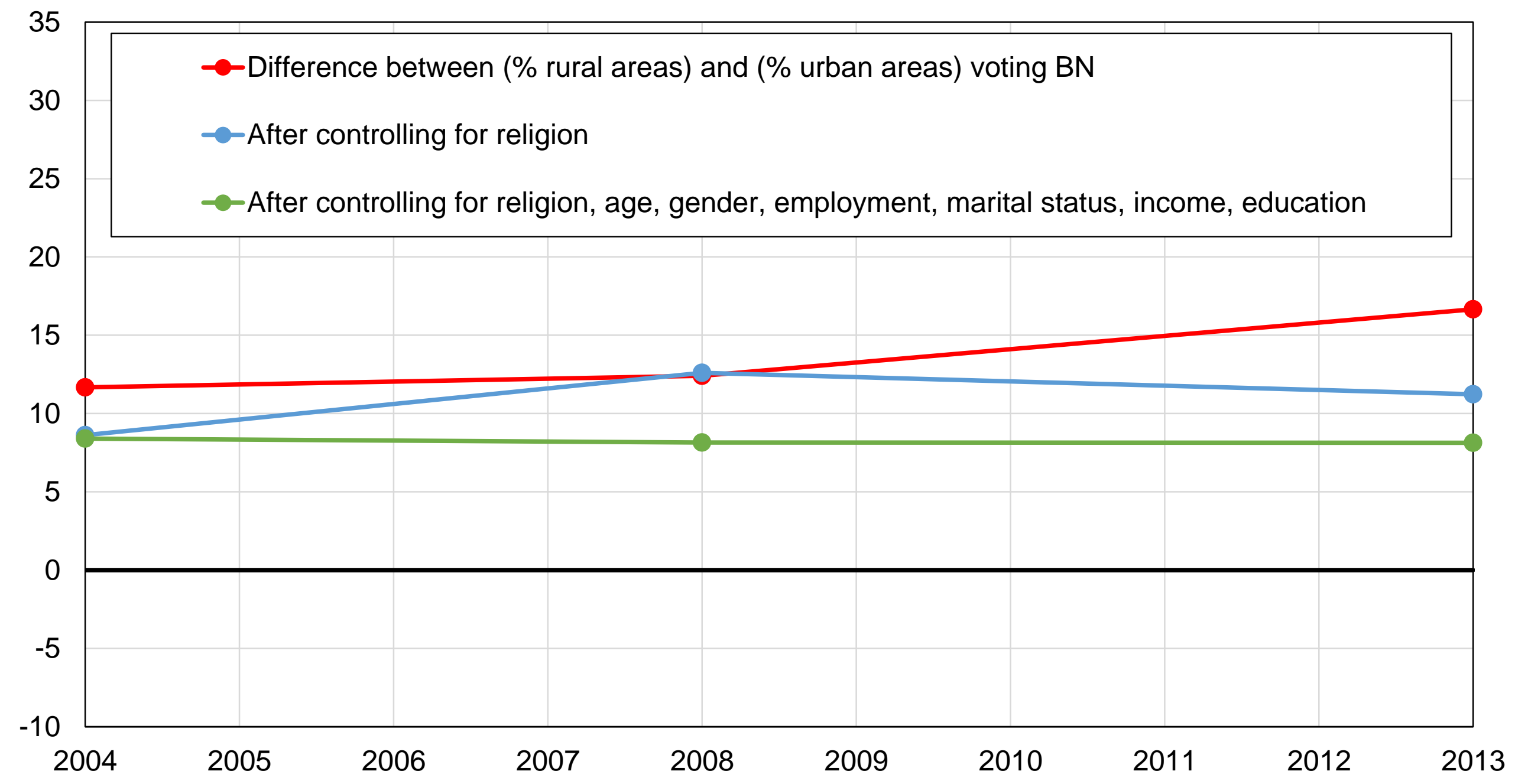

Source: authors' computations using Asian Barometer surveys.

Note: the figure shows the difference between the share of rural areas voting for the Barisan Nasional and the share of urban areas voting for the Barisan Nasional, before and after controls. 


\section{Figure CC7 - Support for the National Front Coalition among older}

voters

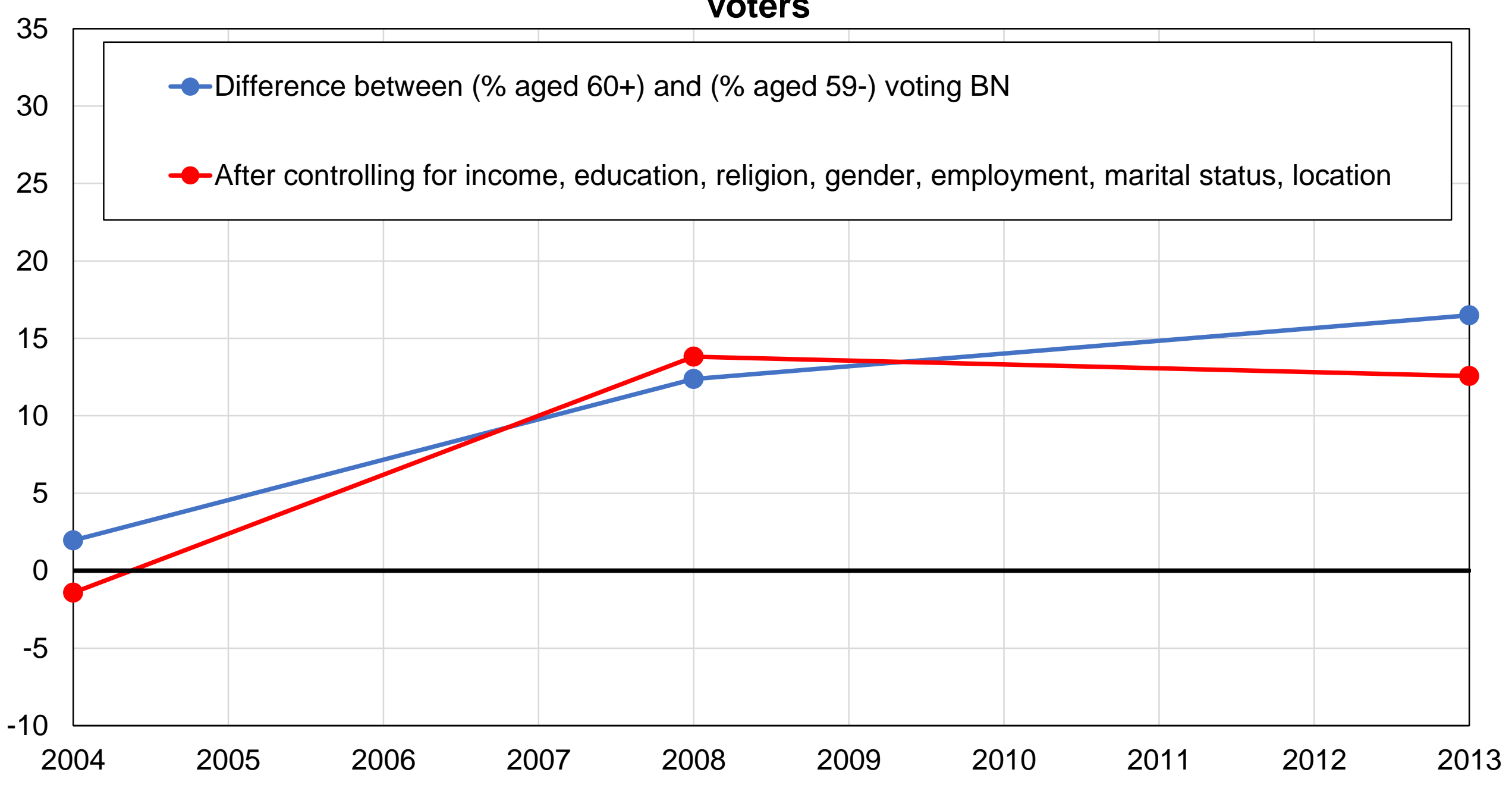

Source: authors' computations using Asian Barometer surveys.

Note: the figure shows the difference between the share of voters aged 60 or more voting for the Barisan Nasional and the share of voters younger than 60 voting for the Barisan Nasional, before and after controls. 


\section{Figure CC8 - Support for the National Front Coalition among men}

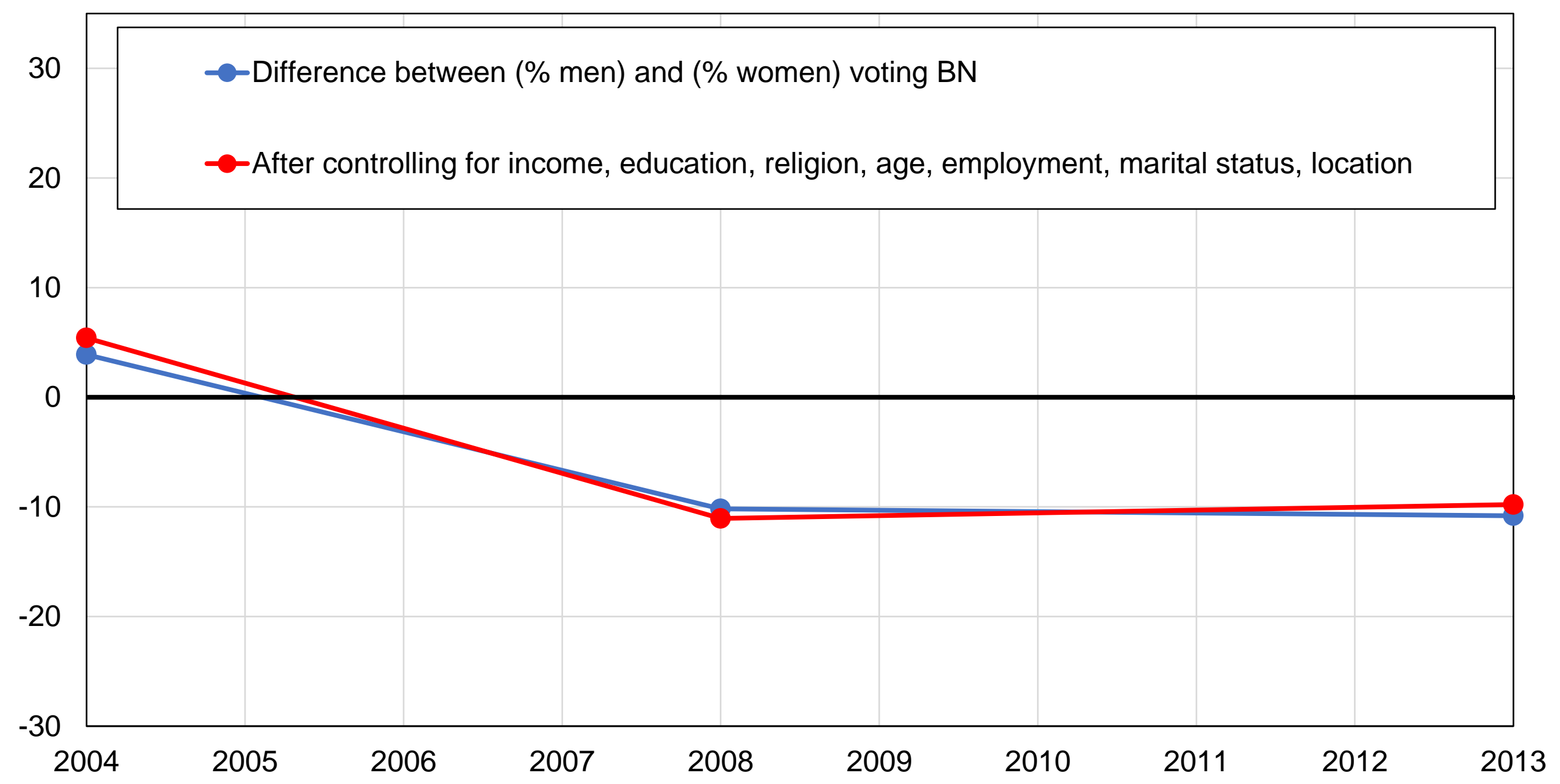

Source: authors' computations using Asian Barometer surveys.

Note: the figure shows the difference between the share of men voting for the Barisan Nasional and the share of women voting for the Barisan Nasional, before and after controls. 
Table C1 - Data sources

Year Survey $\quad$ Source

Sample size

2004 Asian Barometer, Wave 2

Center for East Asia Democratic Studies

1218

2008 Asian Barometer, Wave 3

Center for East Asia Democratic Studies

1214

2013 Asian Barometer, Wave 4

Center for East Asia Democratic Studies

1207 
Table 2 - Composition of the electorate

Location: Rural areas

Education: Primary

Education: Secondary

\begin{tabular}{|ccc|}
\hline 2004 & 2008 & 2013 \\
\hline $17 \%$ & $53 \%$ & $44 \%$ \\
$59 \%$ & $48 \%$ & $49 \%$ \\
$34 \%$ & $37 \%$ & $34 \%$ \\
$7 \%$ & $15 \%$ & $17 \%$ \\
$54 \%$ & $48 \%$ & $55 \%$ \\
$37 \%$ & $41 \%$ & $34 \%$ \\
$9 \%$ & $11 \%$ & $11 \%$ \\
$51 \%$ & $50 \%$ & $51 \%$ \\
$58 \%$ & $54 \%$ & $62 \%$ \\
$2 \%$ & $7 \%$ & $3 \%$ \\
$40 \%$ & $39 \%$ & $35 \%$ \\
$65 \%$ & $69 \%$ & $65 \%$ \\
$23 \%$ & $28 \%$ & $25 \%$ \\
$7 \%$ & $7 \%$ & $7 \%$ \\
$59 \%$ & $58 \%$ & $61 \%$ \\
$11 \%$ & $7 \%$ & $7 \%$ \\
\hline
\end{tabular}

Education: Tertiary

Age: $20-39$

Age: $40-59$

Age: $60+$

Gender: Men

Employment status: Employed

Employment status: Unemployed

Employment status: Inactive

Marital status: Married or with partner

Religion: Buddhist / Taoist

Religion: Hindu / Sikh

Religion: Muslim

Religion: Christian

Source: authors' computations using Asian Barometer Surveys.

Note: the table shows descriptive statistics by year for selected available variables. 
Figure DA1 - Election results in Indonesia, 1971-2019

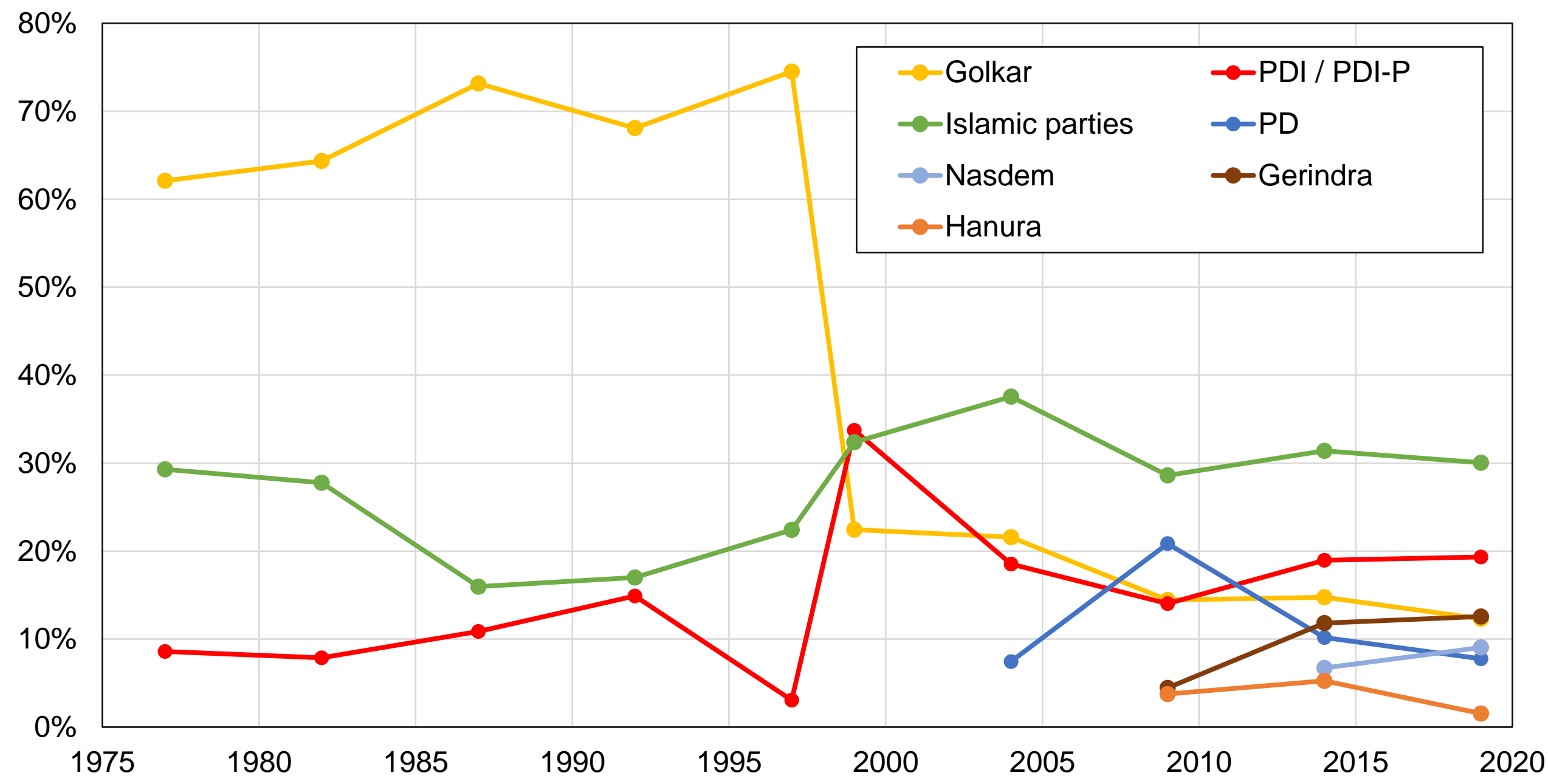

Source: authors' computations using official election results.

Note: the figure shows the share of votes received by selected Indonesian political parties or groups of parties in legislative elections between 1977 and 2019. Islamic parties include the PAN, PBB, PBR, PKB, PKNU, PKS, and PPP. 
Figure DA2 - Election results in Indonesia by group, 1971-2019

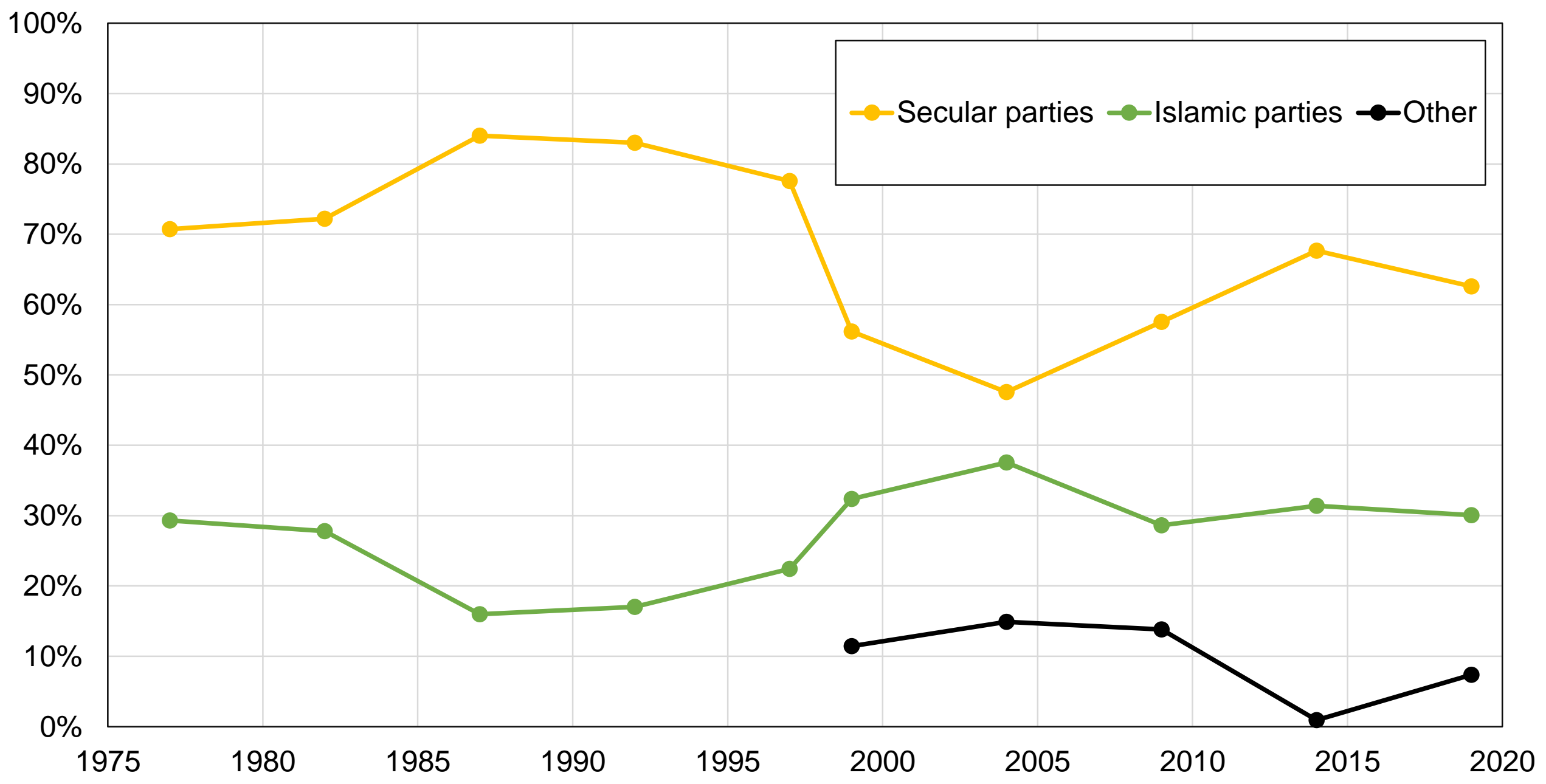

Source: authors' computations using official election results.

Note: the figure shows the share of votes received by selected Indonesian political parties or groups of parties in legislative elections between 1977 and 2019. Islamic parties include the PAN, PBB, PBR, PKB, PKNU, PKS, and PPP. 
Figure DA3 - Composition of the electorate by education level

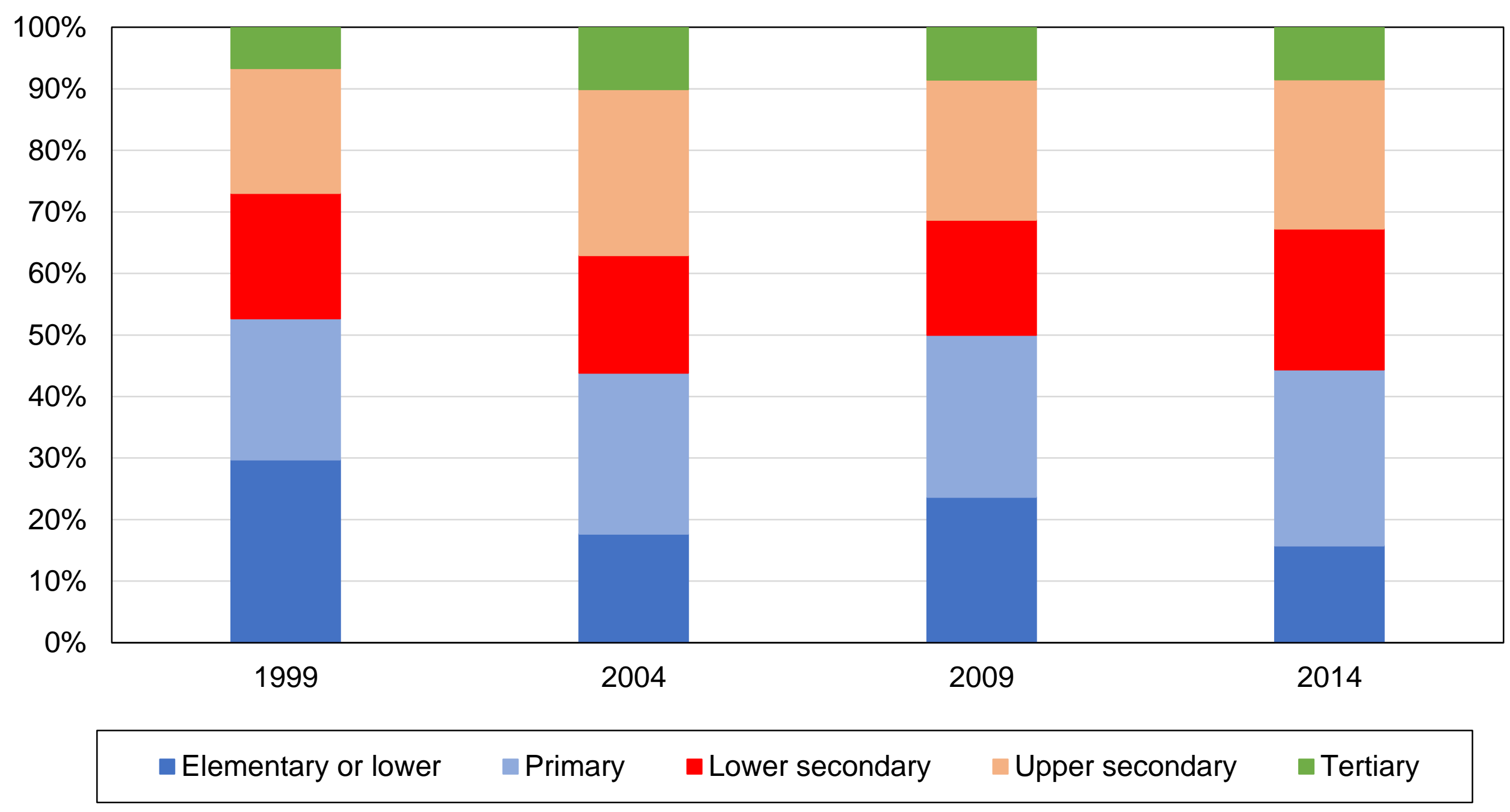

Source: authors' computations using Indonesian political attitudes surveys. Note: the figure shows the composition of the electorate by education level. 
Figure DA4 - Composition of the electorate by age group

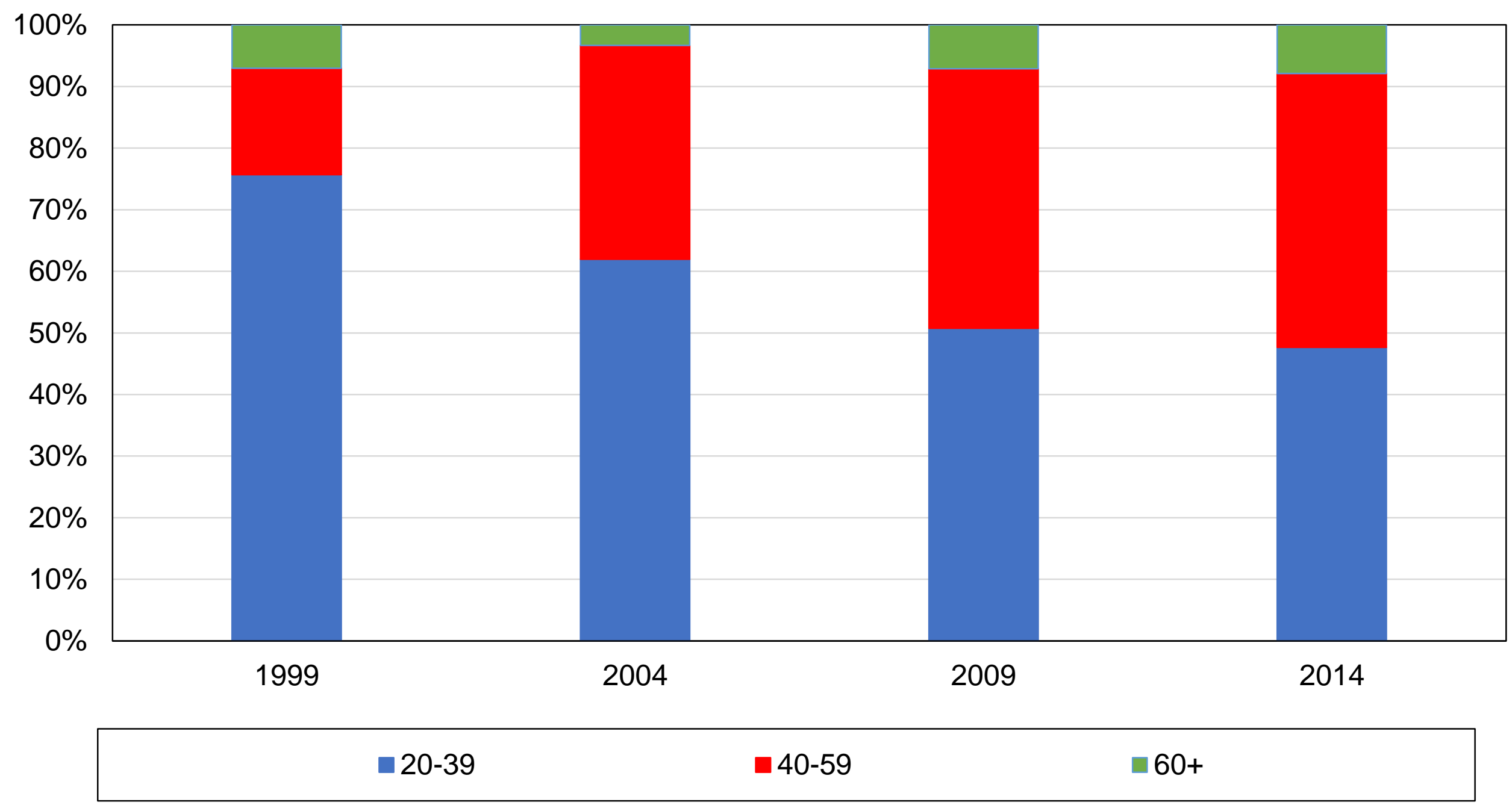

Source: authors' computations using Indonesian political attitudes surveys. Note: the figure shows the composition of the electorate by age group. 
Figure DA5 - Composition of the electorate by religion

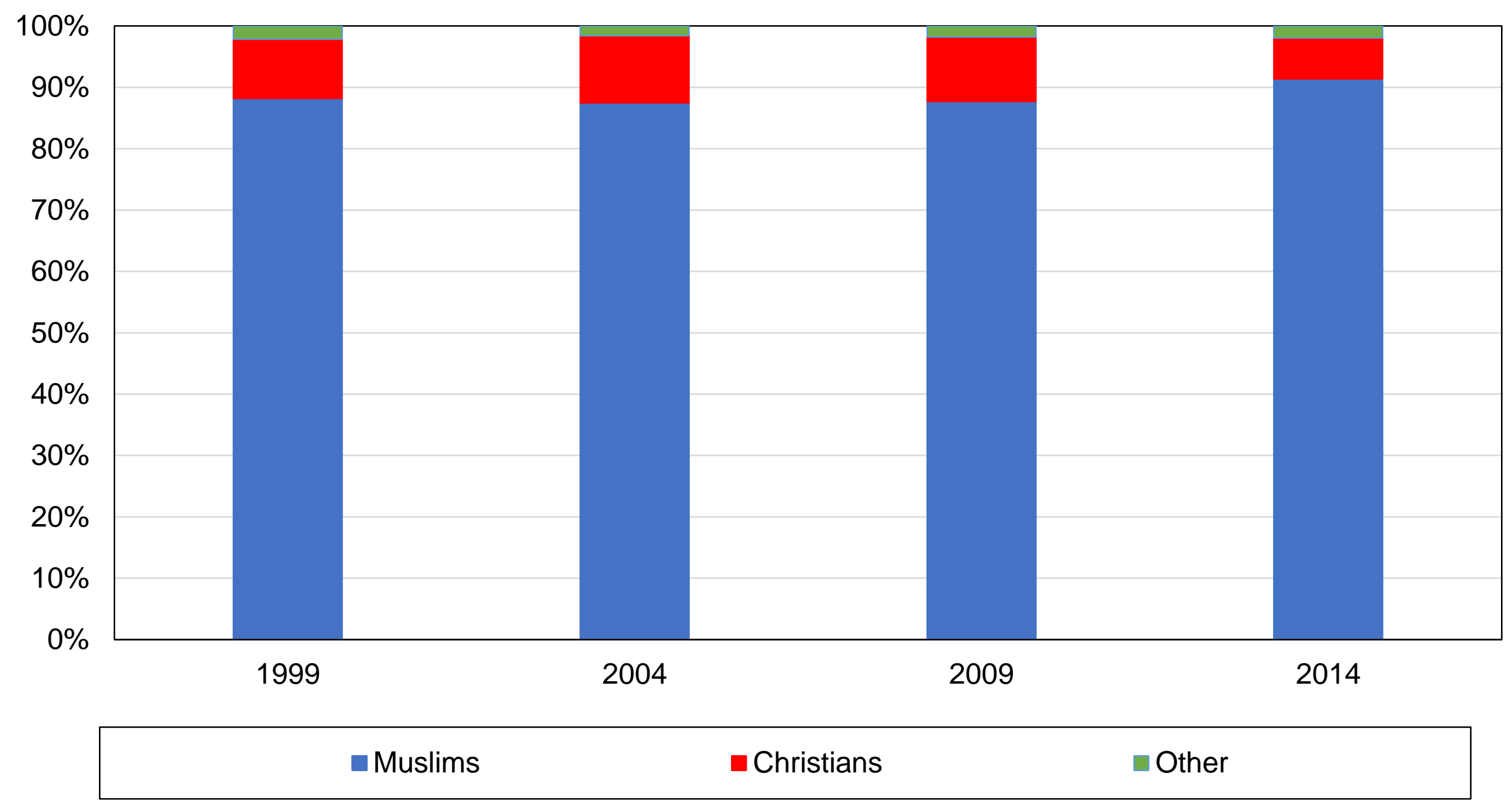

Source: authors' computations using Indonesian political attitudes surveys.

Note: the figure shows the composition of the electorate by religious affiliation. 
Figure DA6 - Composition of the electorate by rural-urban location

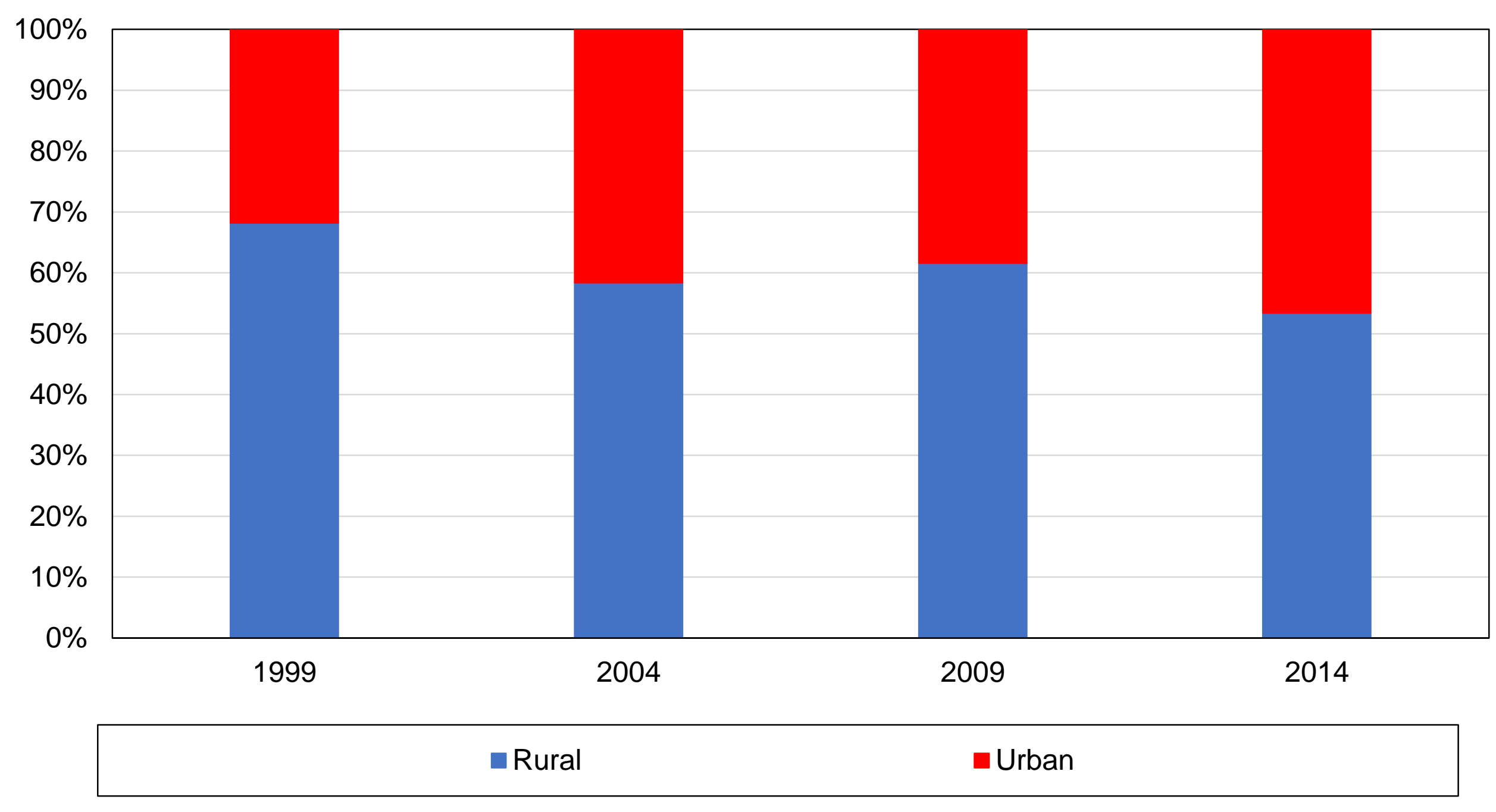

Source: authors' computations using Indonesian political attitudes surveys.

Note: the figure shows the composition of the electorate by rural-urban location. 
Figure DA7 - Composition of income quintiles by religion, 1999

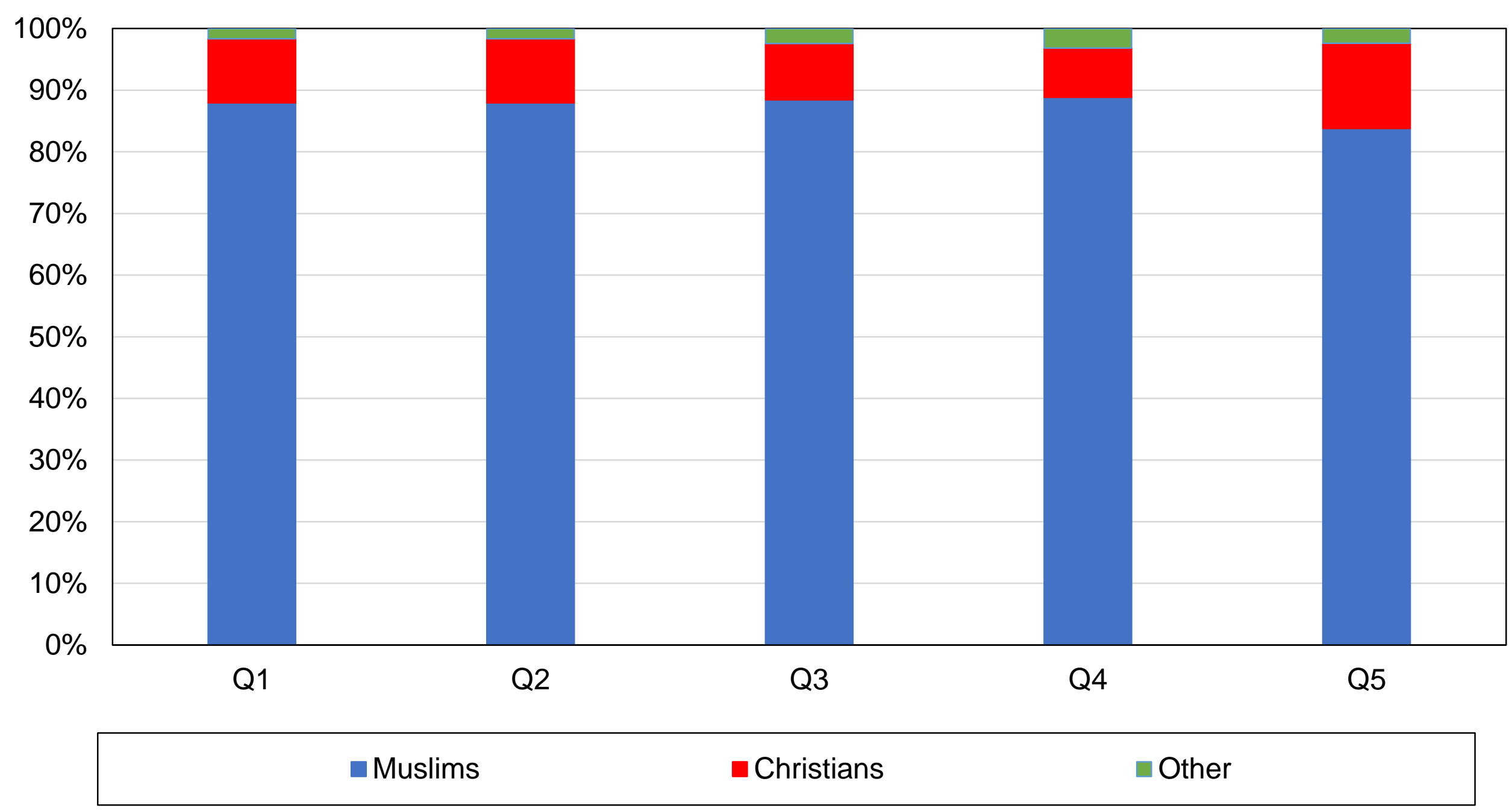

Source: authors' computations using Indonesian political attitudes surveys.

Note: the figure shows the composition of income quintiles by religious affiliation in 1999. 
Figure DA8 - Composition of income quintiles by religion, 2014

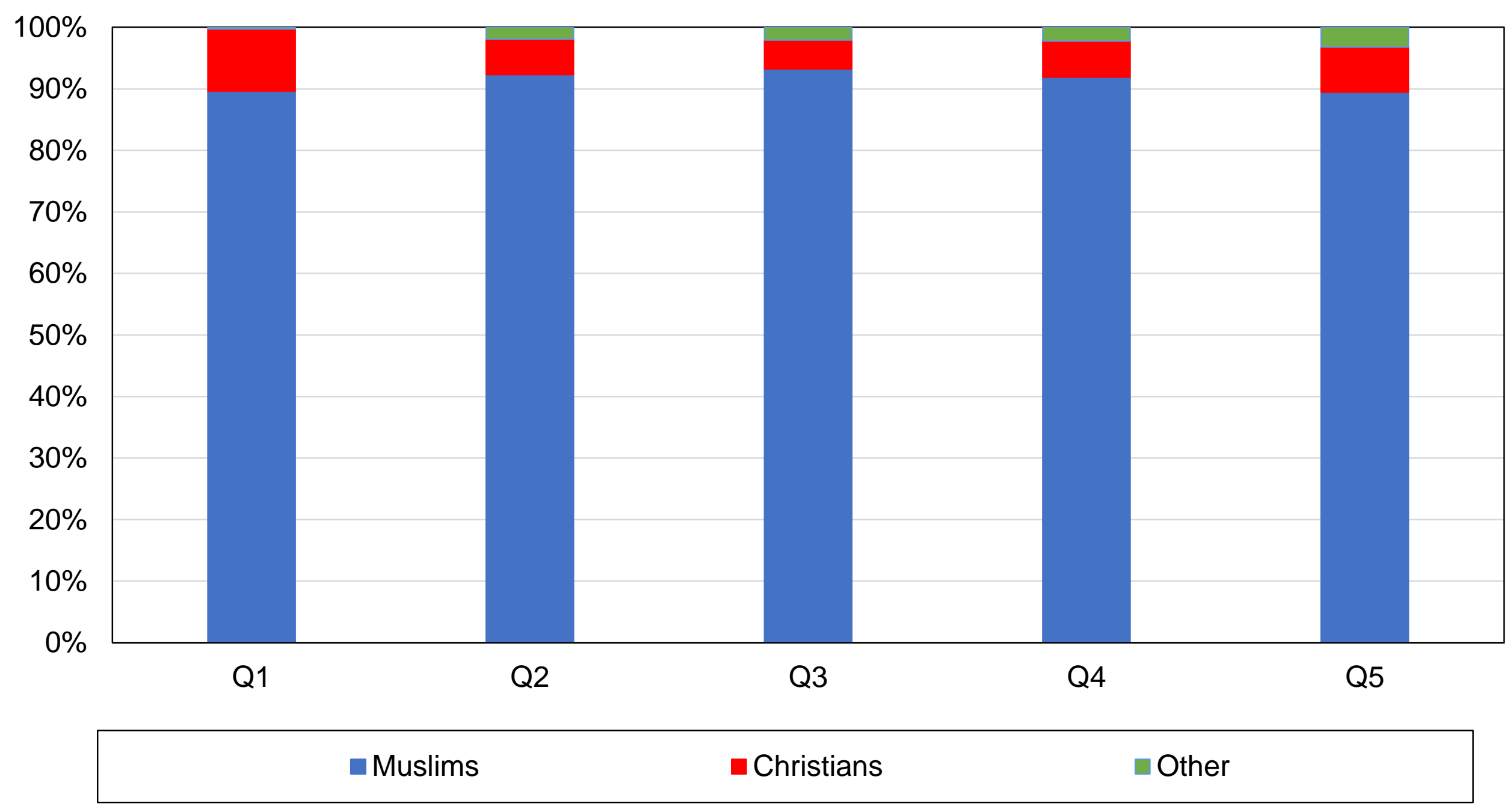

Source: authors' computations using Indonesian political attitudes surveys.

Note: the figure shows the composition of income quintiles by religious affiliation in 2014 . 
Figure DA9 - Composition of income quintiles by education, 1999

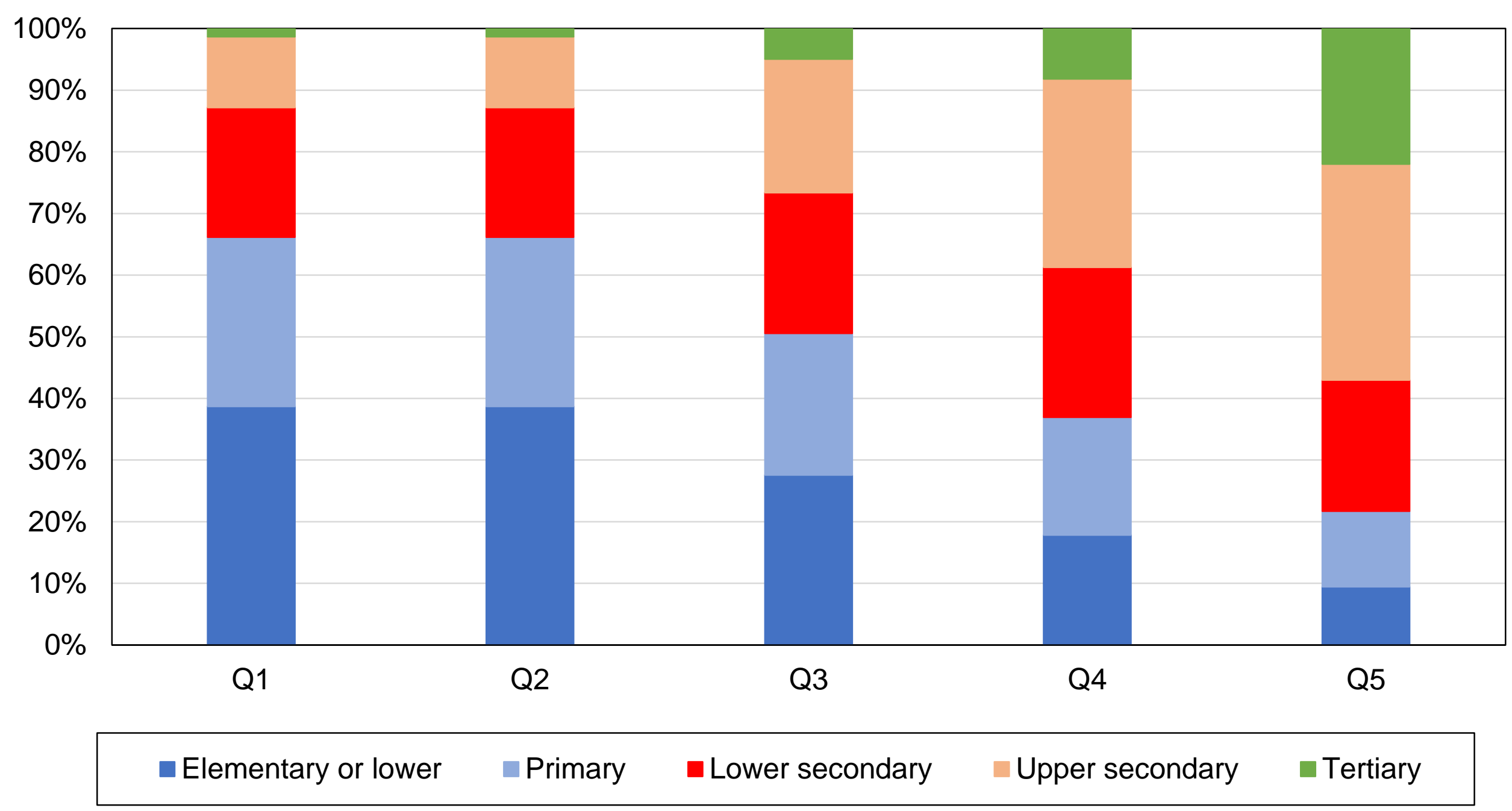

Source: authors' computations using Indonesian political attitudes surveys.

Note: the figure shows the composition of income quintiles by education level in 1999 . 
Figure DA10 - Composition of income quintiles by education, 2014

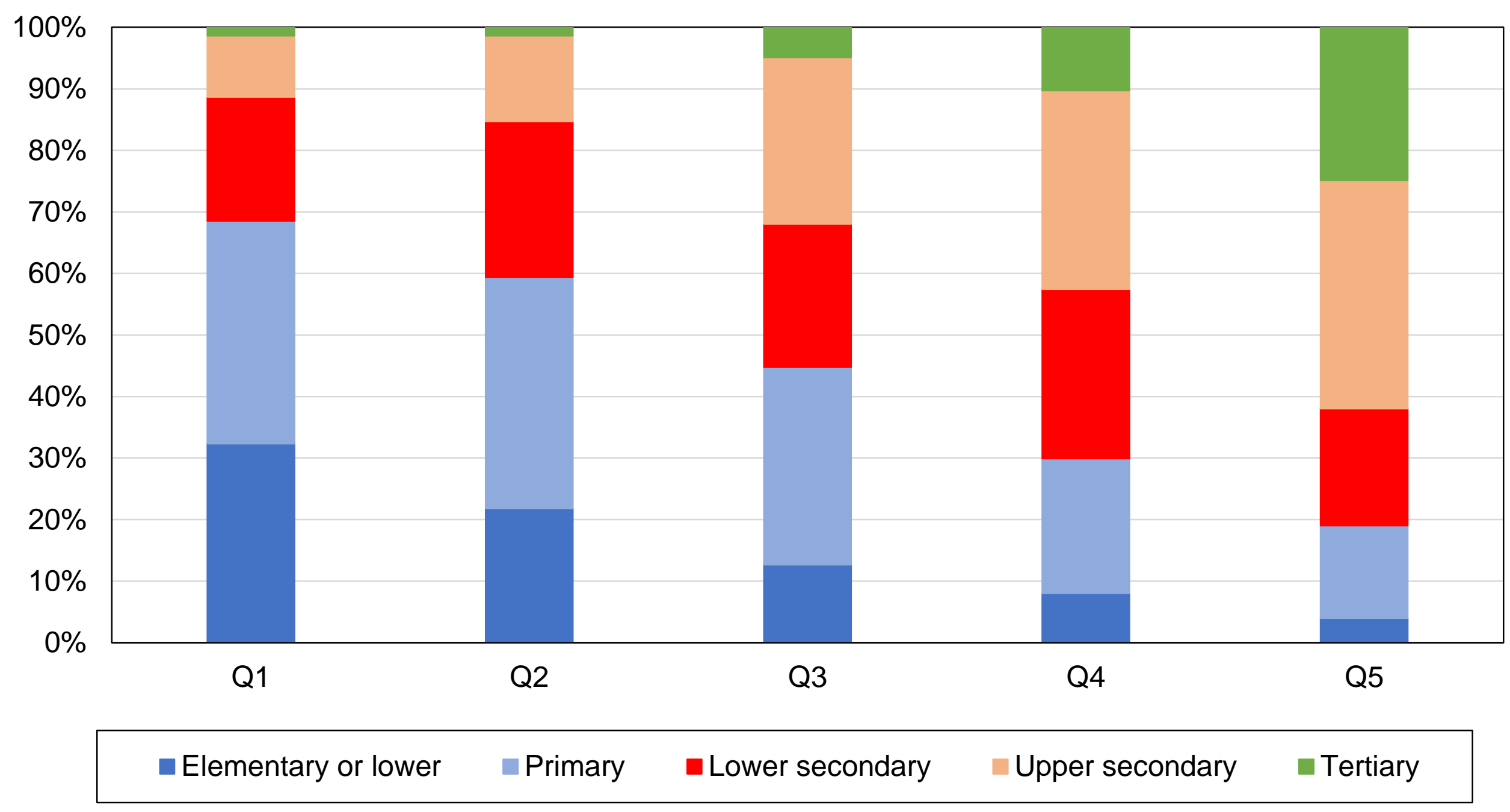

Source: authors' computations using Indonesian political attitudes surveys.

Note: the figure shows the composition of income quintiles by education level in 2014 . 
Figure DA11 - Rural-urban composition of income deciles, 1999

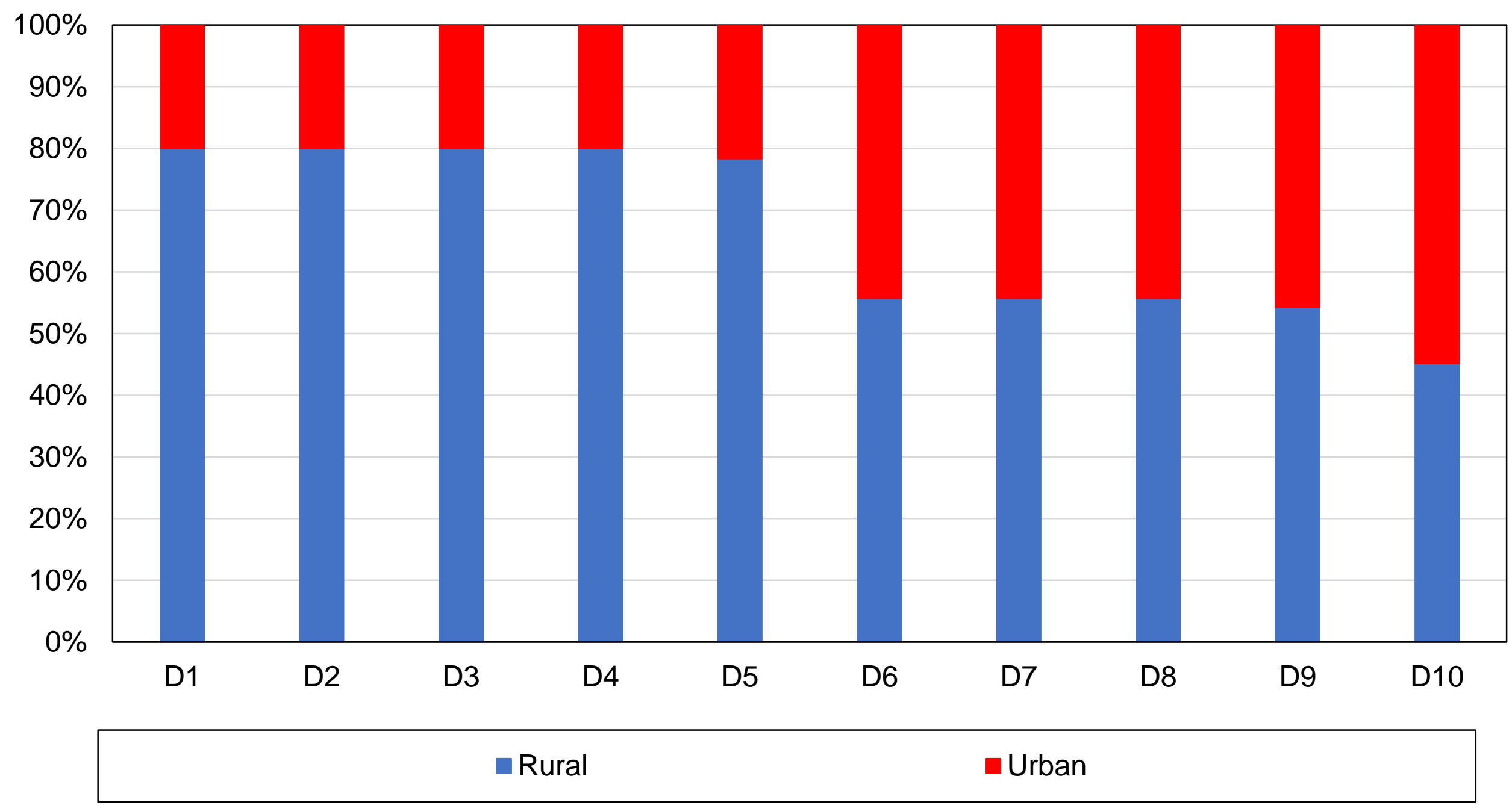

Source: authors' computations using Indonesian political attitudes surveys.

Note: the figure shows the composition of income deciles by rural-urban location in 1999. 
Figure DA12 - Rural-urban composition of income deciles, 2014

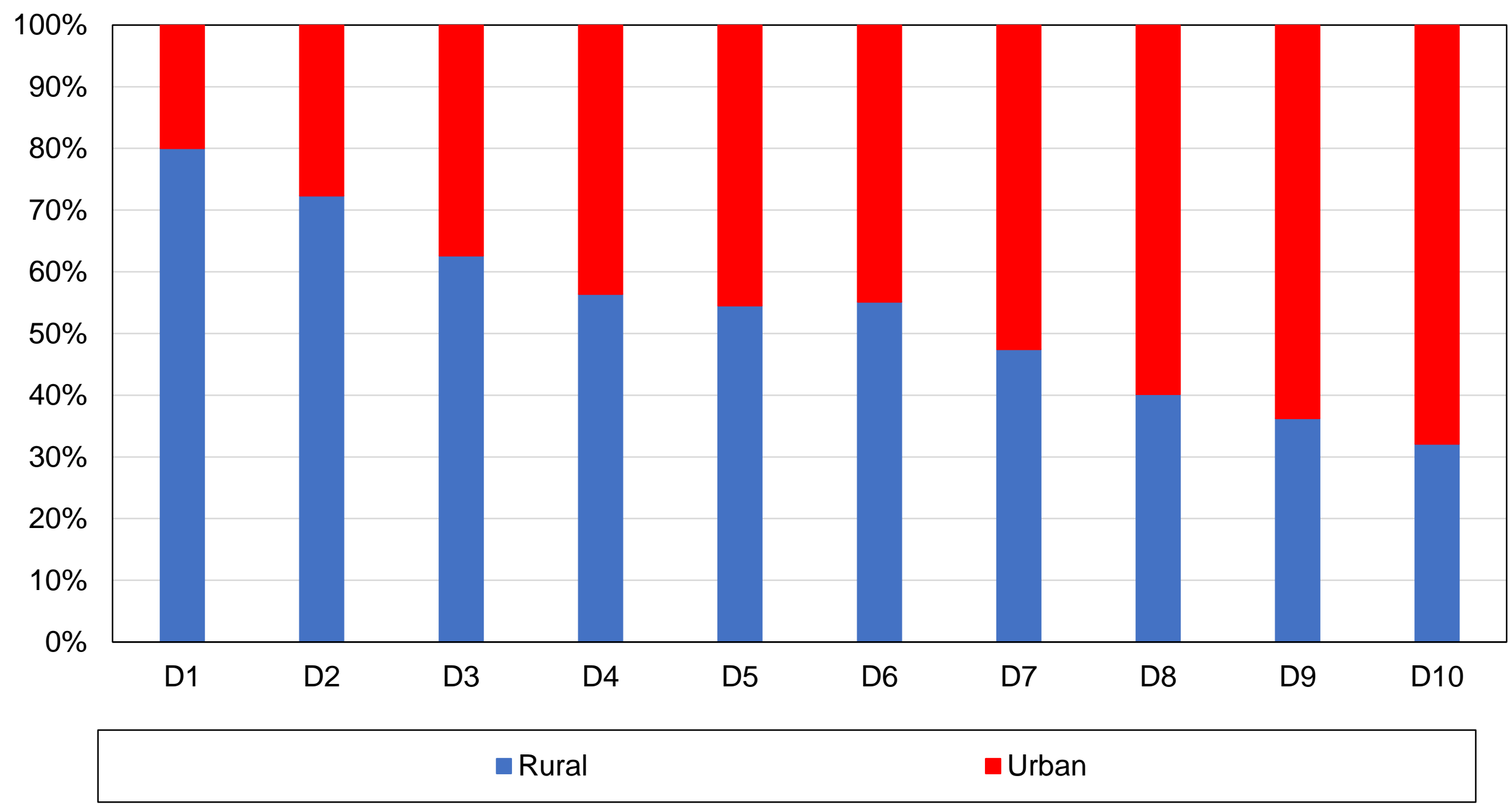

Source: authors' computations using Indonesian political attitudes surveys.

Note: the figure shows the composition of income deciles by rural-urban location in 2014. 
Figure DA13 - Composition of income groups by ethnicity, 1999

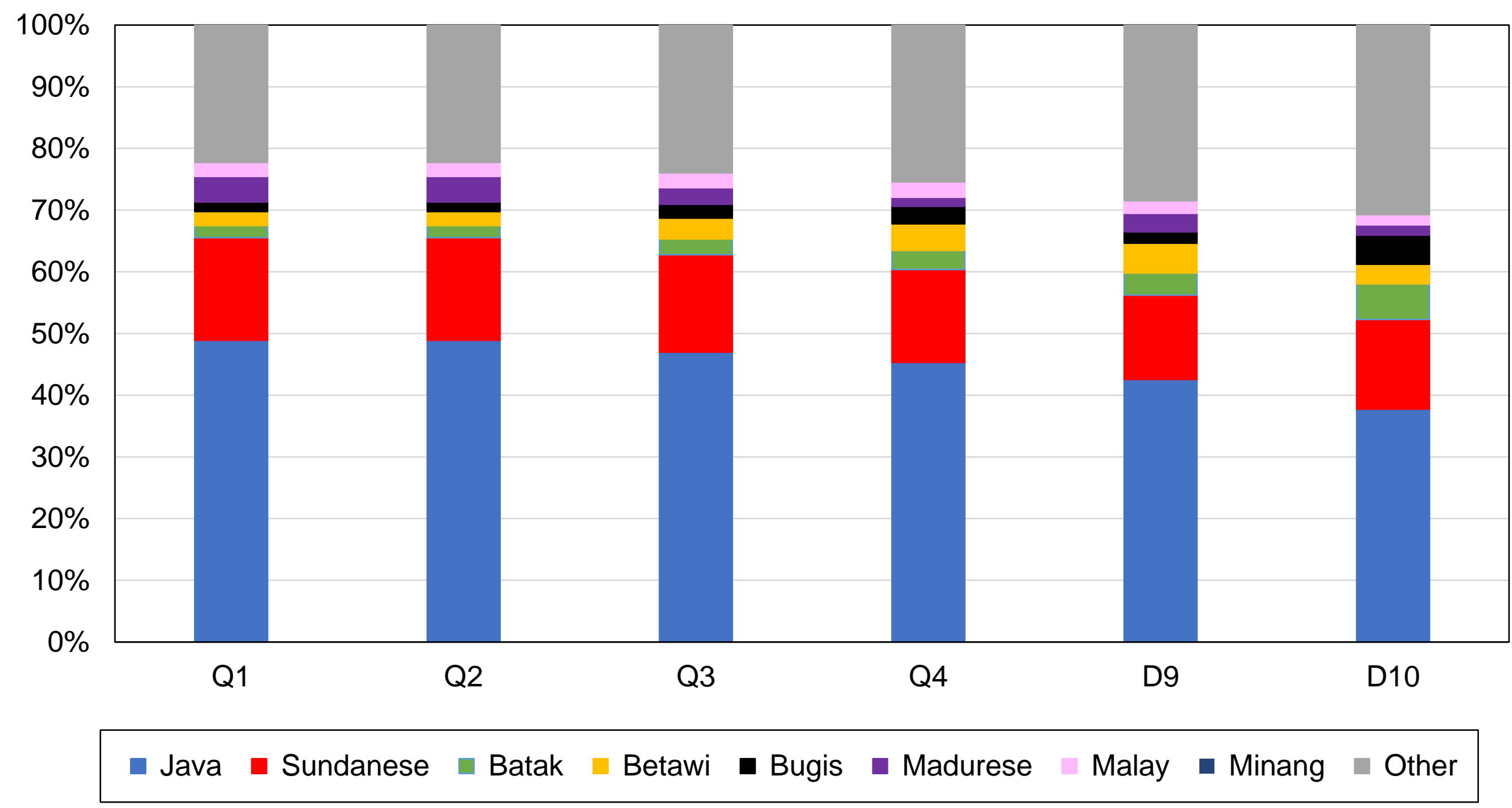

Source: authors' computations using Indonesian political attitudes surveys.

Note: the figure shows the composition of income groups by ethnic affiliation in 1999. 
Figure DA14 - Composition of income groups by ethnicity, 2014

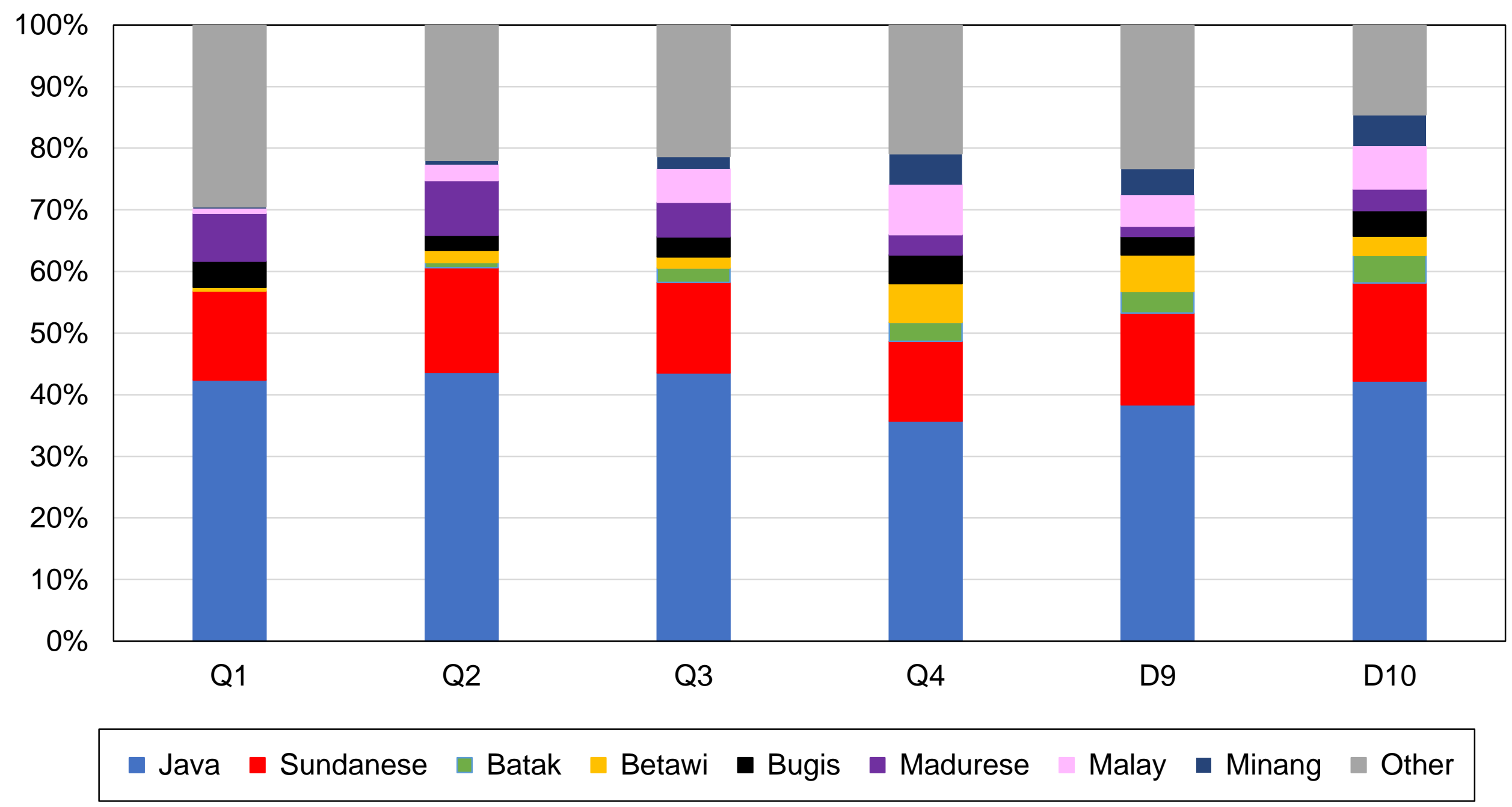

Source: authors' computations using Indonesian political attitudes surveys.

Note: the figure shows the composition of income groups by ethnic affiliation in 2014. 
Figure DA15 - Composition of ethnic groups by income, 1999

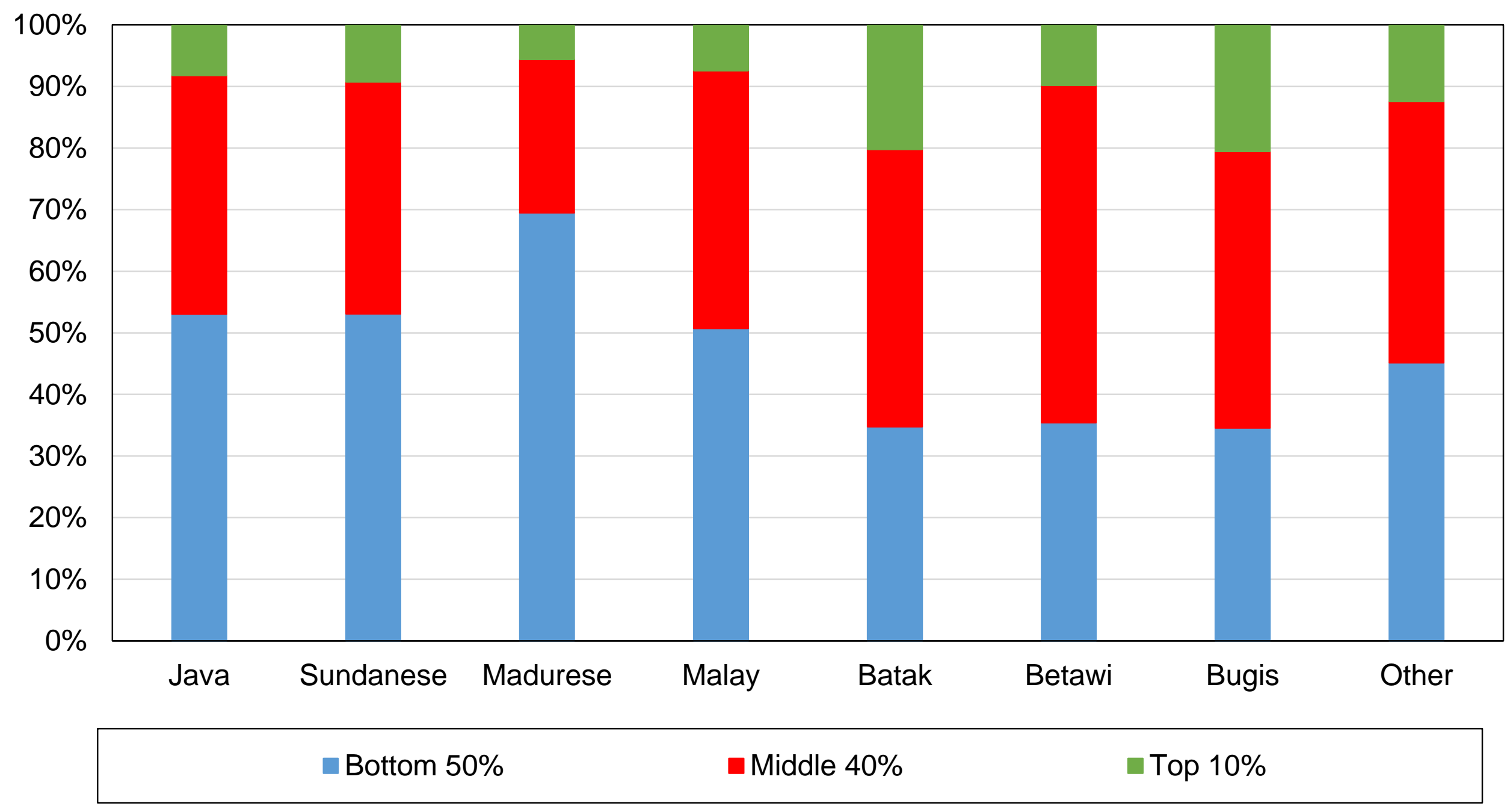

Source: authors' computations using Indonesian political attitudes surveys.

Note: the figure shows the composition of ethnic groups by income group in 1999. 
Figure DA16 - Composition of ethnic groups by income, 2014

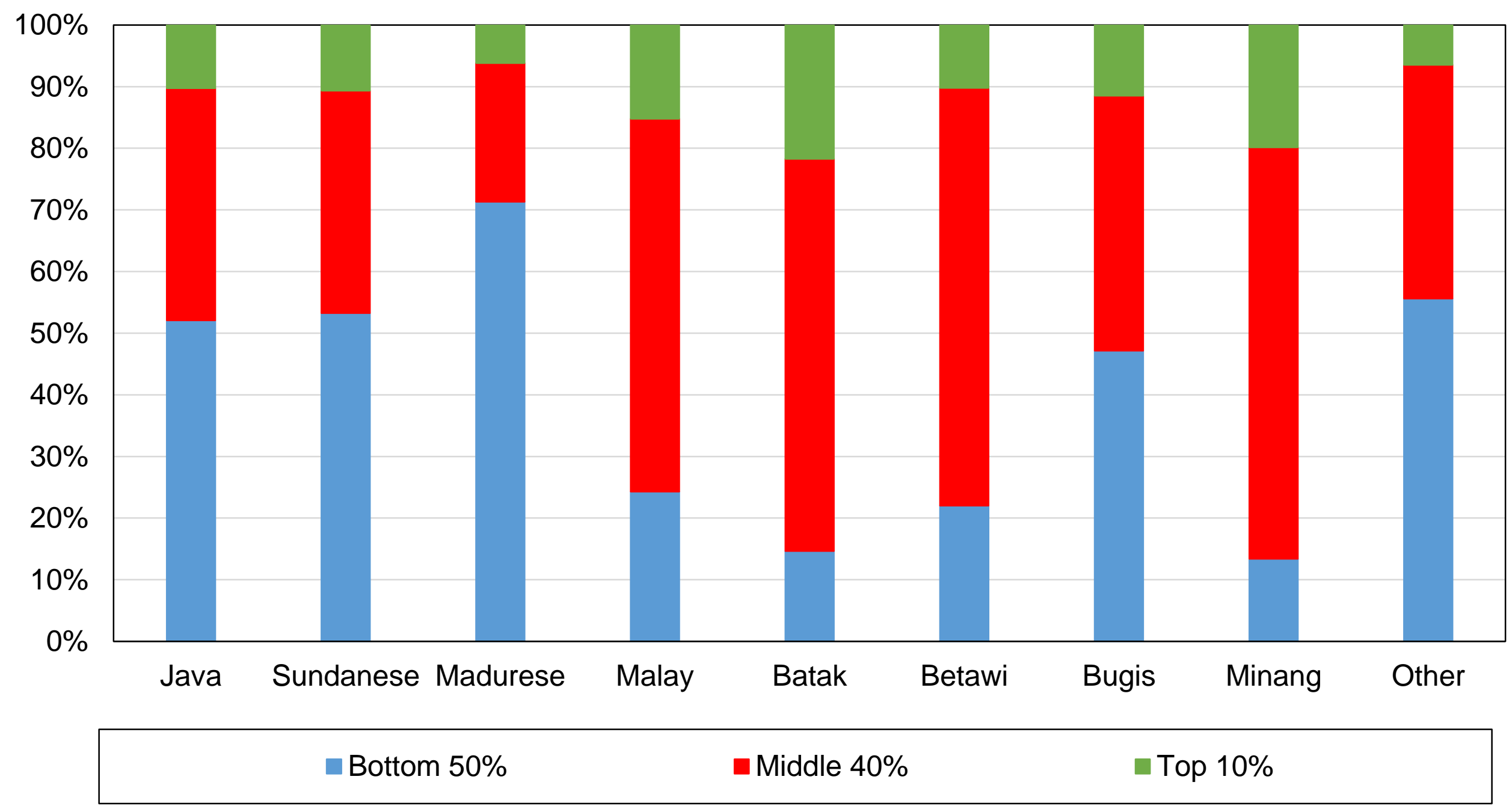

Source: authors' computations using Indonesian political attitudes surveys.

Note: the figure shows the composition of ethnic groups by income group in 2014. 


\section{Figure DB1 - Vote for Golkar/Gerindra/Hanura by education level}

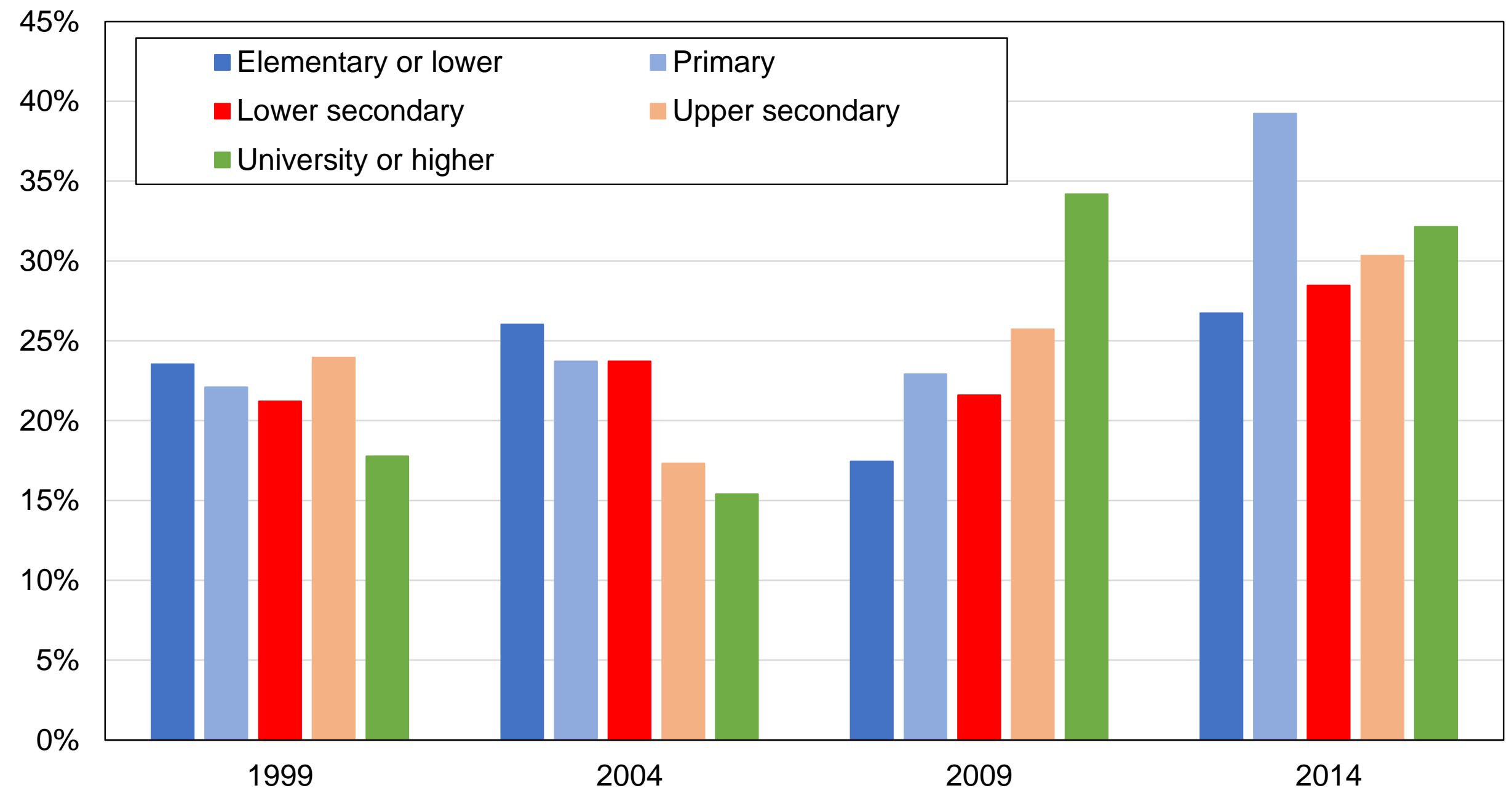

Source: authors' computations using Indonesian political attitudes surveys.

Note: the figure shows the share of votes received by Golkar/Gerindra/Hanura by education level. 


\section{Figure DB2 - Vote for Golkar/Gerindra/Hanura among higher-educated voters}

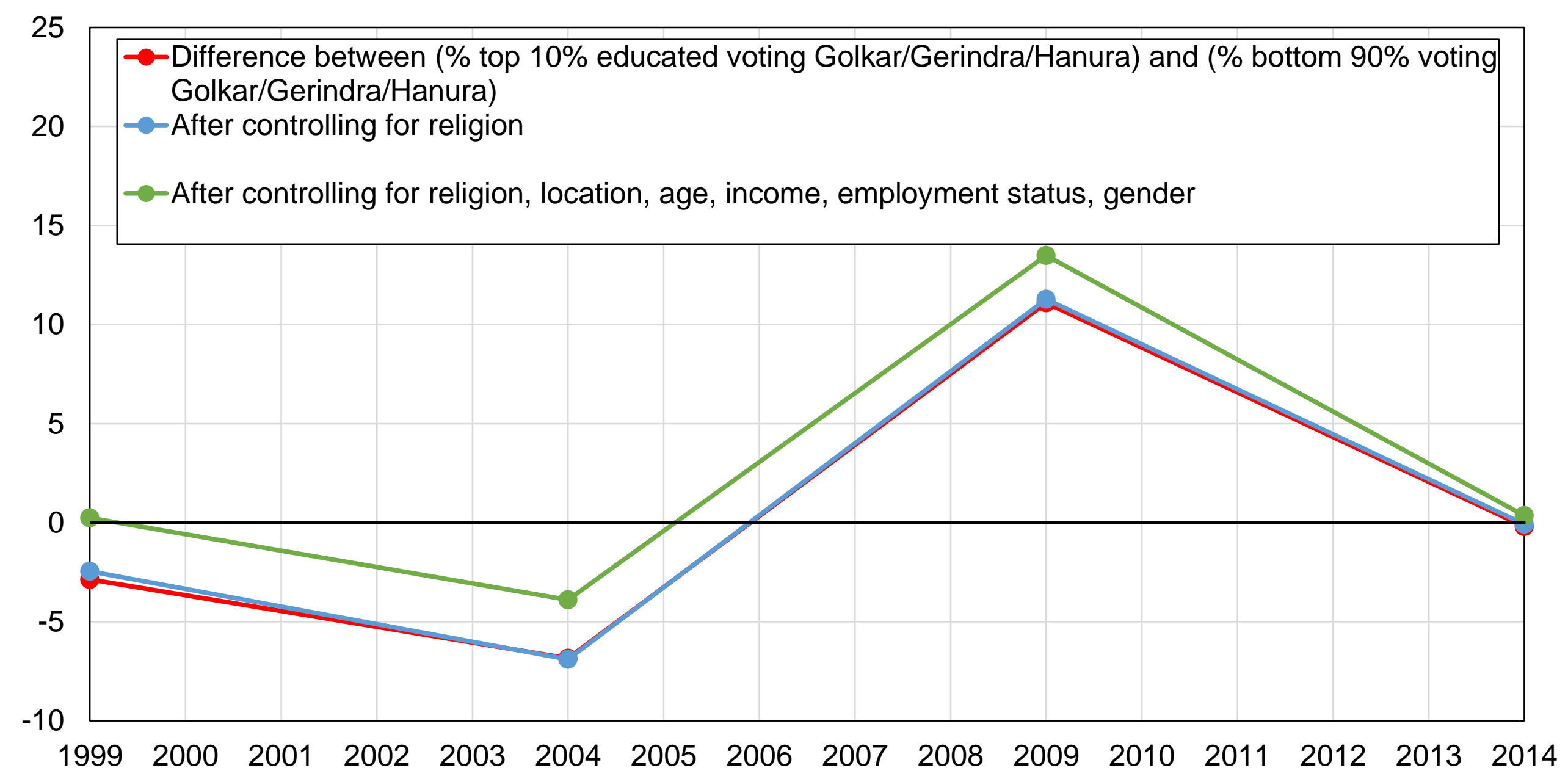

Source: authors' computations using Indonesian political attitudes surveys.

Note: the figure shows the difference between the share of top $10 \%$ educated voters voting for

Golkar/Gerindra/Hanura and the share of other voters voting for these parties, before and after controls. 
Figure DB3 - Vote for Golkar/Gerindra/Hanura by income group

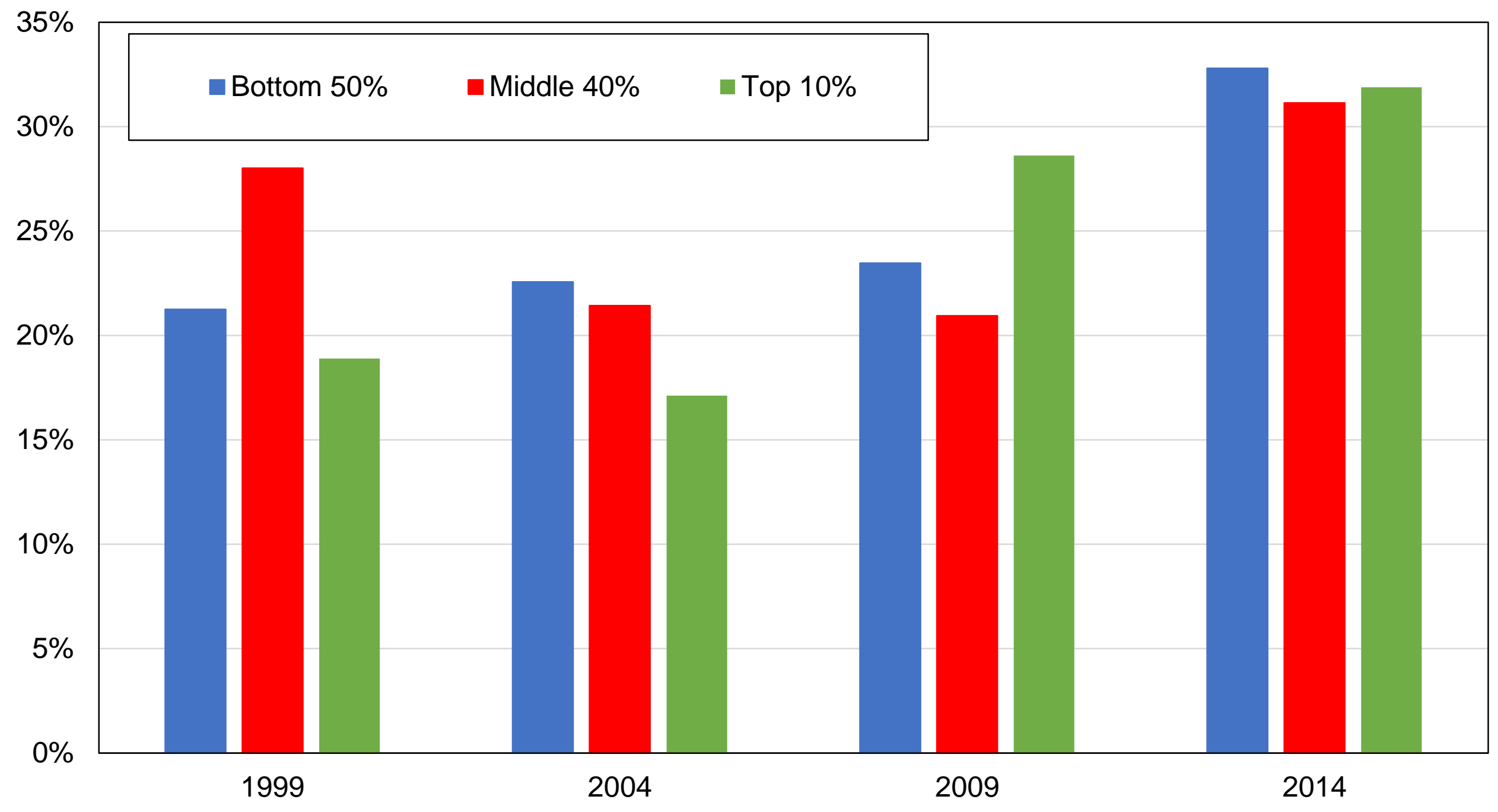

Source: authors' computations using Indonesian political attitudes surveys.

Note: the figure shows the share of votes received by Golkar/Gerindra/Hanura by income group. 


\section{Figure DB4 - Vote for Golkar/Gerindra/Hanura among top-income voters}

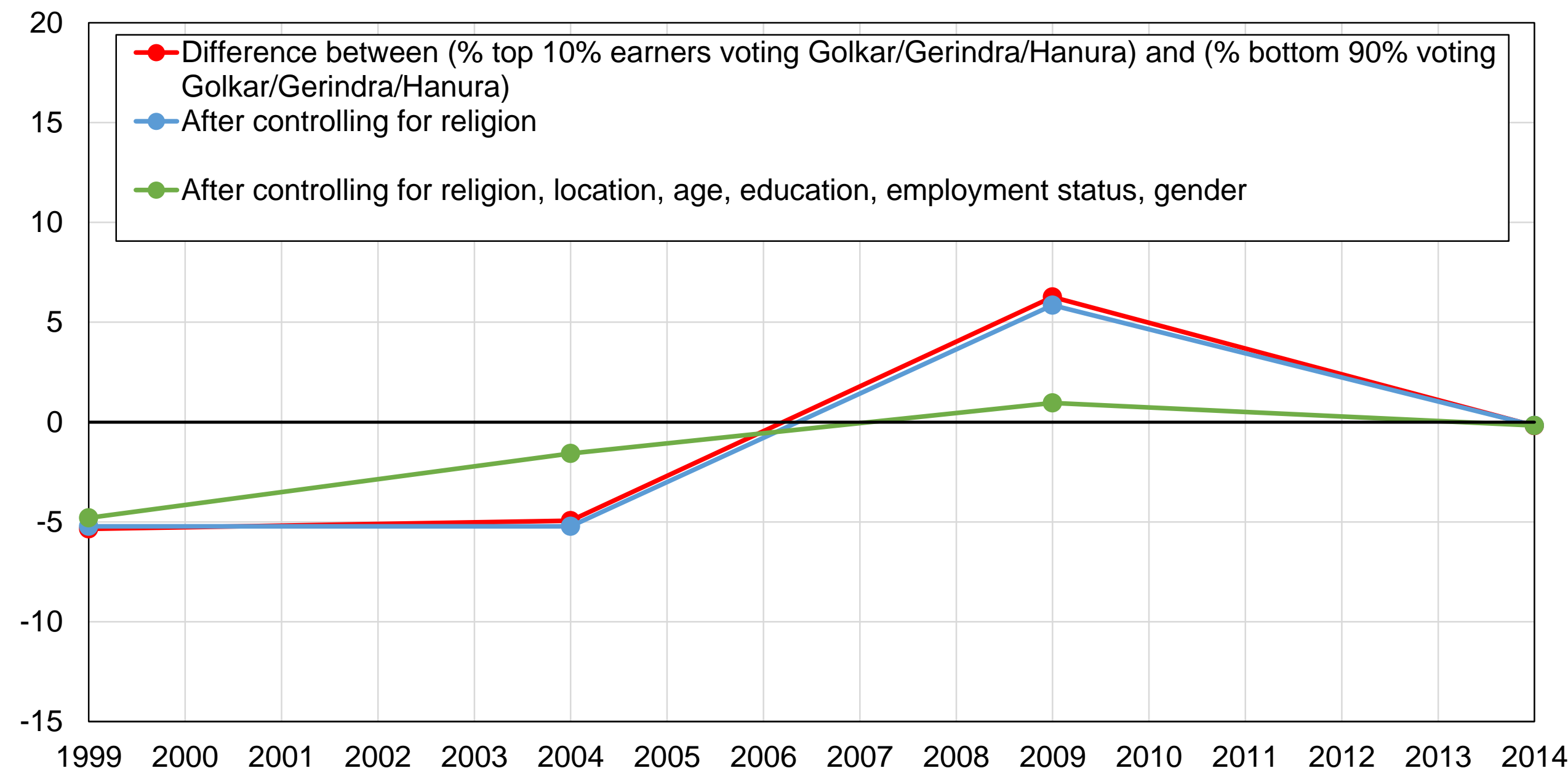

Source: authors' computations using Indonesian political attitudes surveys.

Note: the figure shows the difference between the share of top 10\% earners voting for Golkar/Gerindra/Hanura and the share of other voters voting for Golkar/Gerindra/Hanura, before and after controls. 
Figure DB5 - Vote for Golkar/Gerindra/Hanura by religion

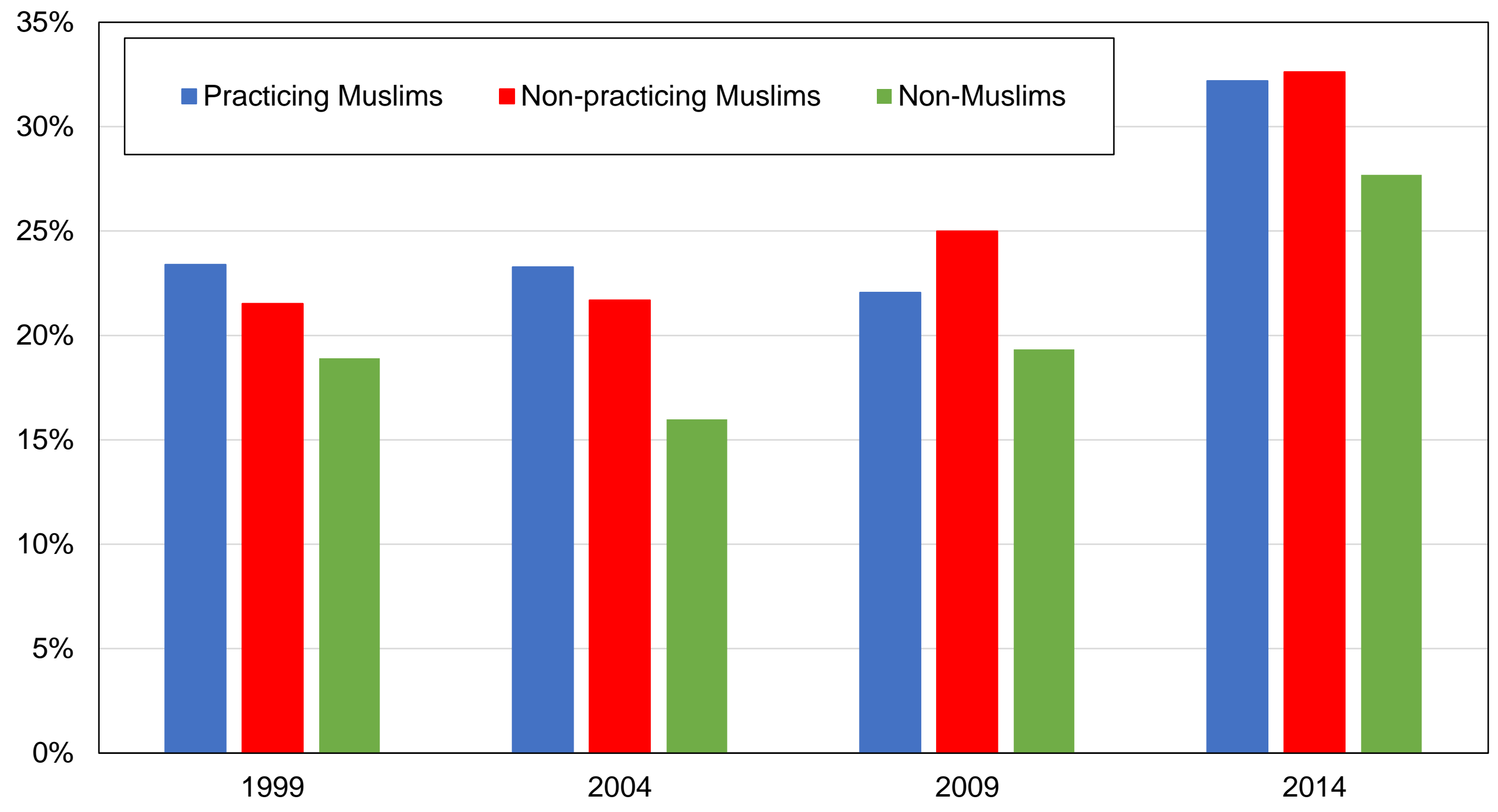

Source: authors' computations using Indonesian political attitudes surveys.

Note: the figure shows the share of votes received by Golkar/Gerindra/Hanura by religion. 


\section{Figure DB6 - Vote for Golkar/Gerindra/Hanura among practicing Muslims}

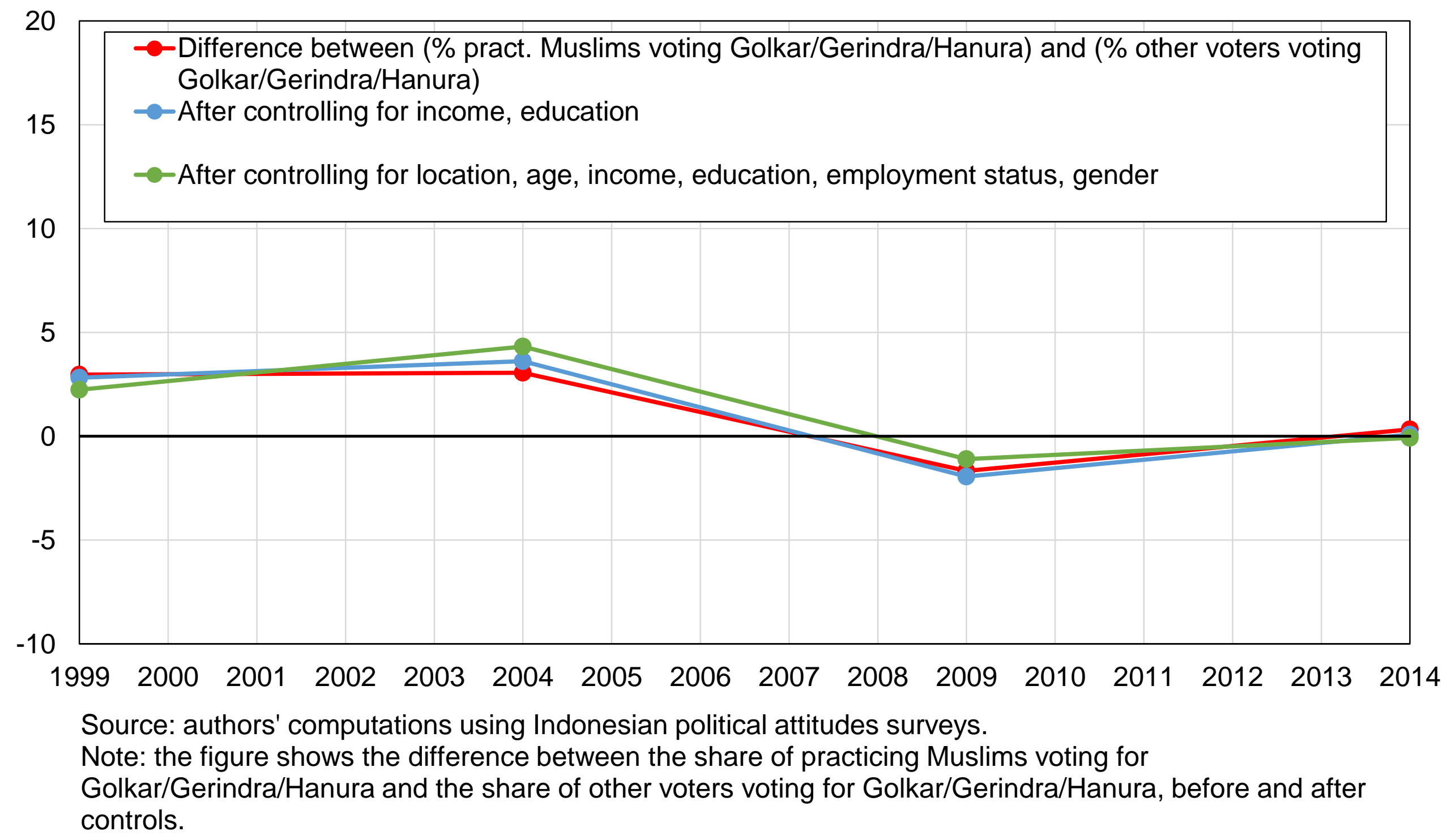


Figure DB7 - Vote for Golkar/Gerindra/Hanura by age group

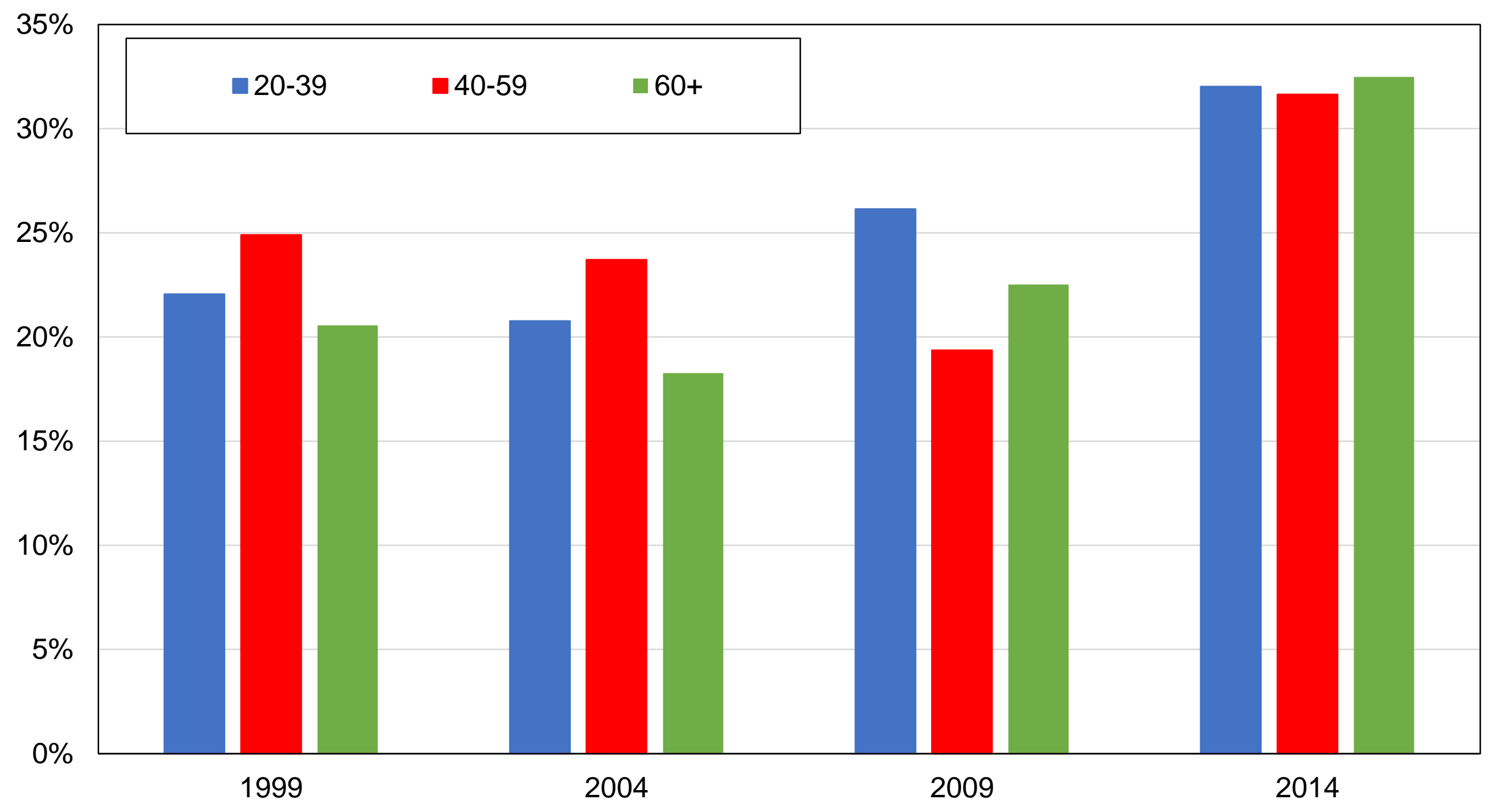

Source: authors' computations using Indonesian political attitudes surveys.

Note: the figure shows the share of votes received by Golkar/Gerindra/Hanura by age group. 


\section{Figure DB8 - Vote for Golkar/Gerindra/Hanura among young voters}

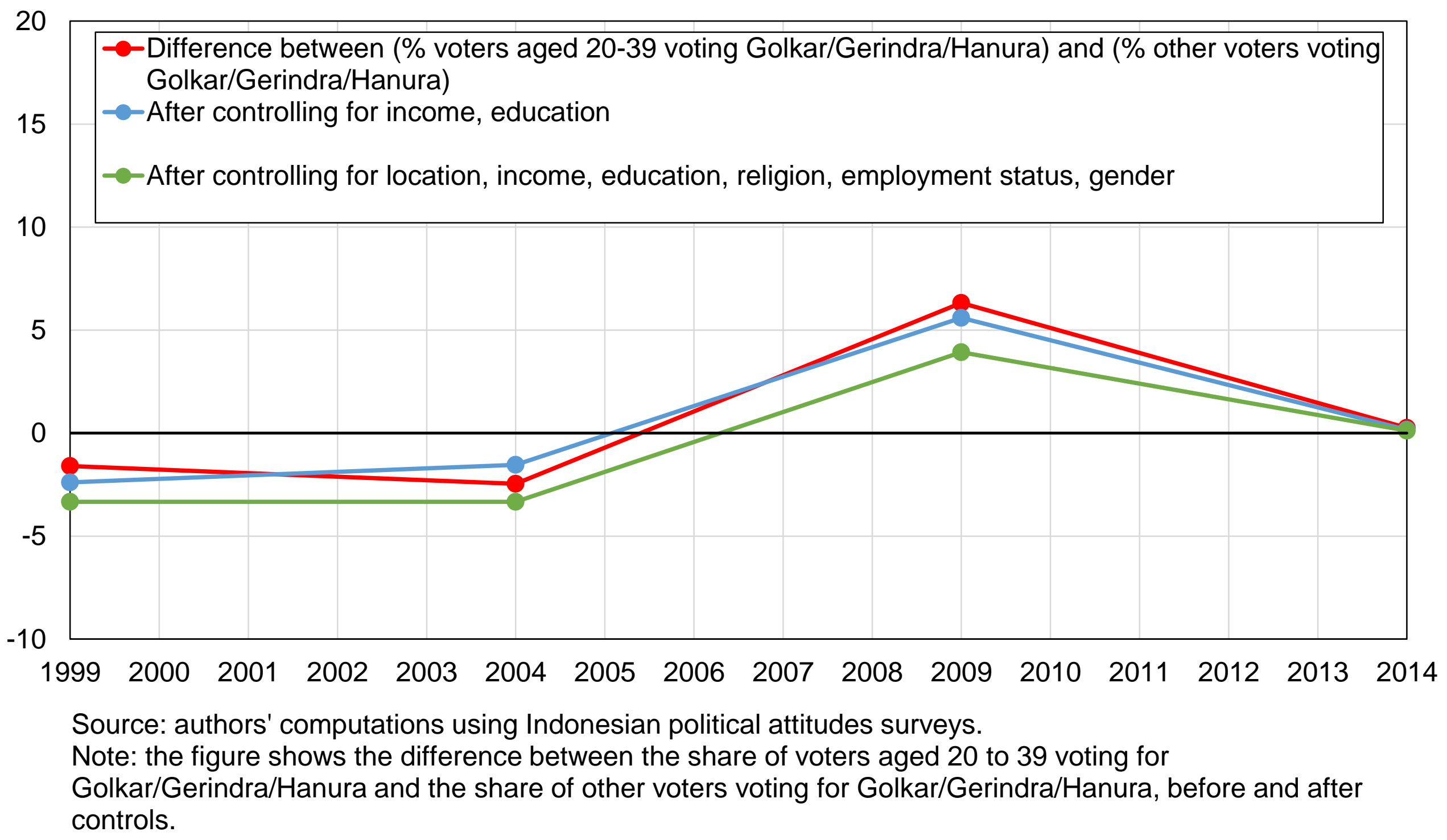


Figure DB9 - Vote for Golkar/Gerindra/Hanura by rural-urban location

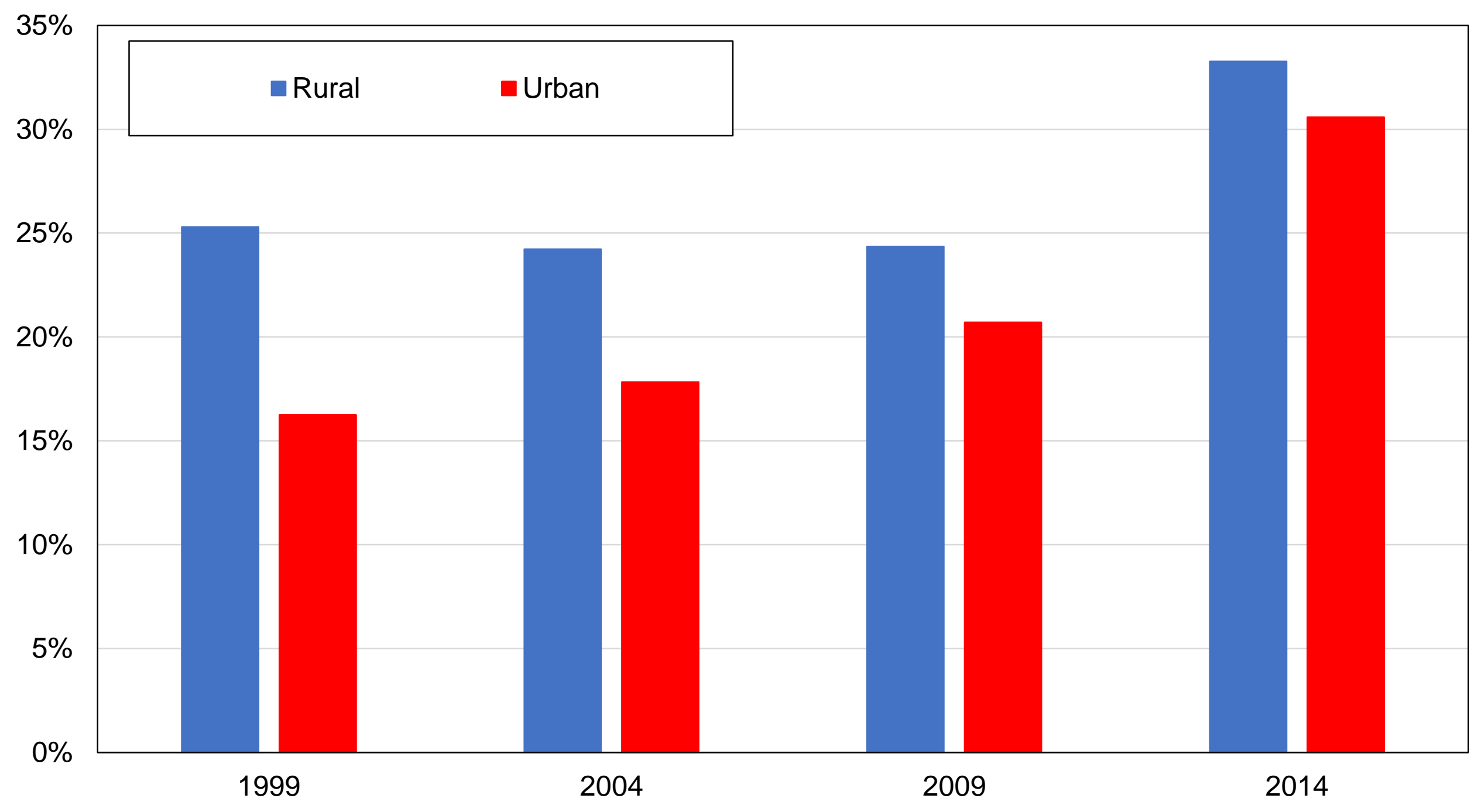

Source: authors' computations using Indonesian political attitudes surveys.

Note: the figure shows the share of votes received by Golkar/Gerindra/Hanura by rural-urban location. 


\section{Figure DB10 - Vote for Golkar/Gerindra/Hanura among urban voters}

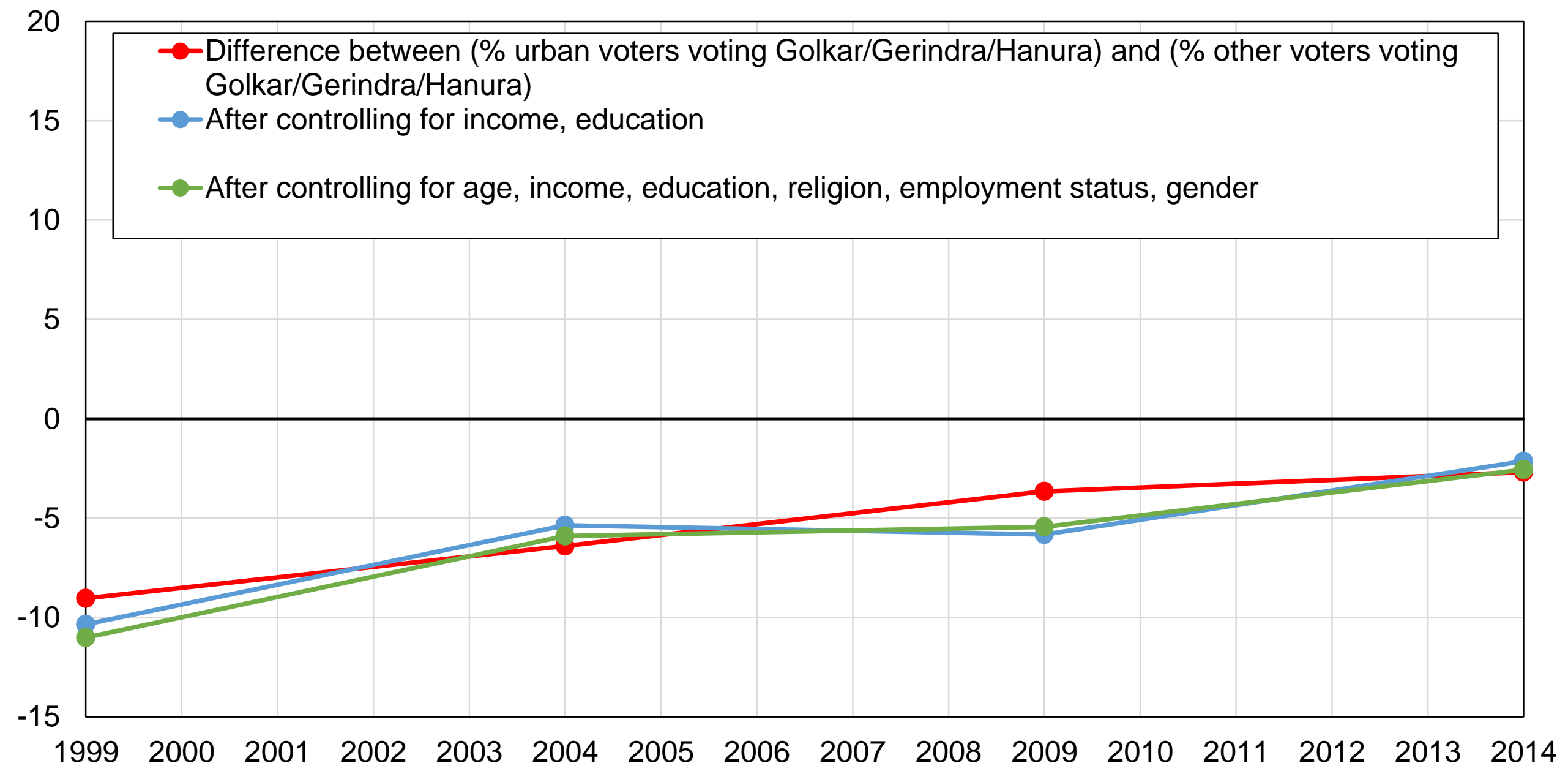

Source: authors' computations using Indonesian political attitudes surveys.

Note: the figure shows the difference between the share of urban voters voting for Golkar/Gerindra/Hanura and the share of other voters voting for Golkar/Gerindra/Hanura, before and after controls. 


\section{Figure DB11 - Vote for Golkar/Gerindra/Hanura by ethnicity}

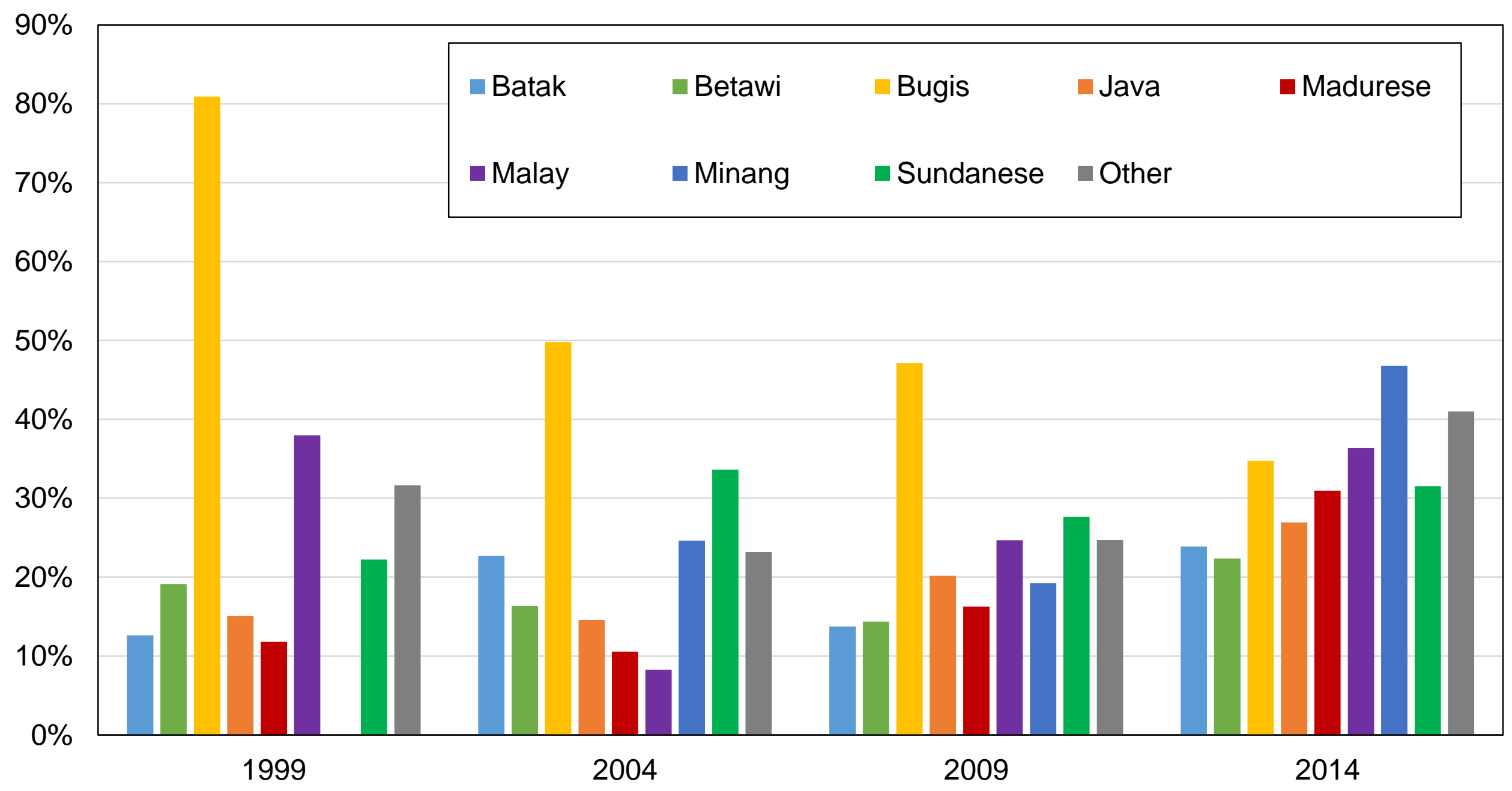

Source: authors' computations using Indonesian political attitudes surveys.

Note: the figure shows the share of votes received by Golkar/Gerindra/Hanura by ethnic affiliation. 


\section{Figure DB12 - Vote for Golkar/Gerindra/Hanura among Javanese voters}

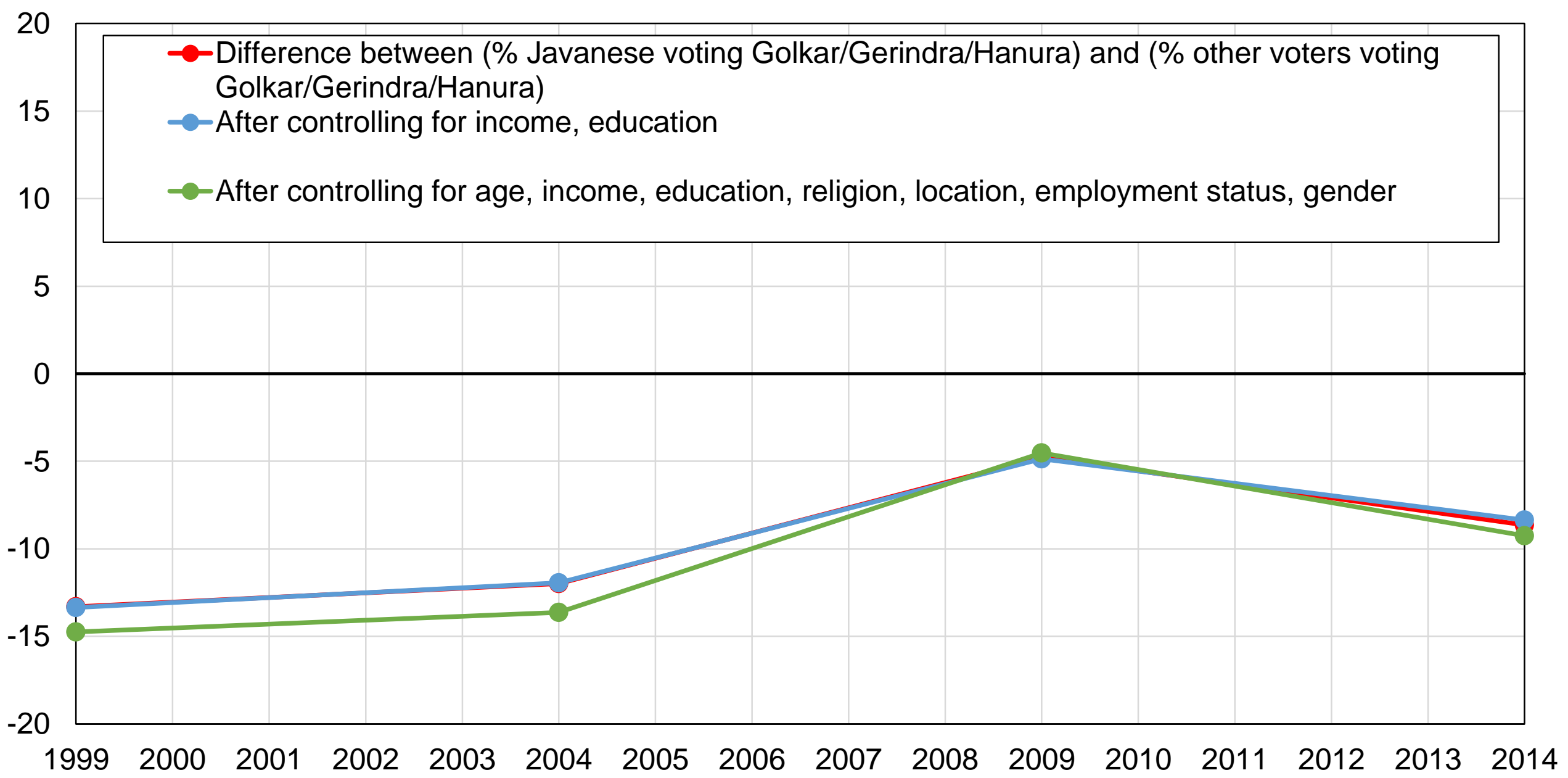

Source: authors' computations using Indonesian political attitudes surveys.

Note: the figure shows the difference between the share of Javanese voters voting for Golkar/Gerindra/Hanura and the share of other voters voting for Golkar/Gerindra/Hanura, before and after controls. 


\section{Figure DC1 - Vote for PDI-P/NasDem by education level}

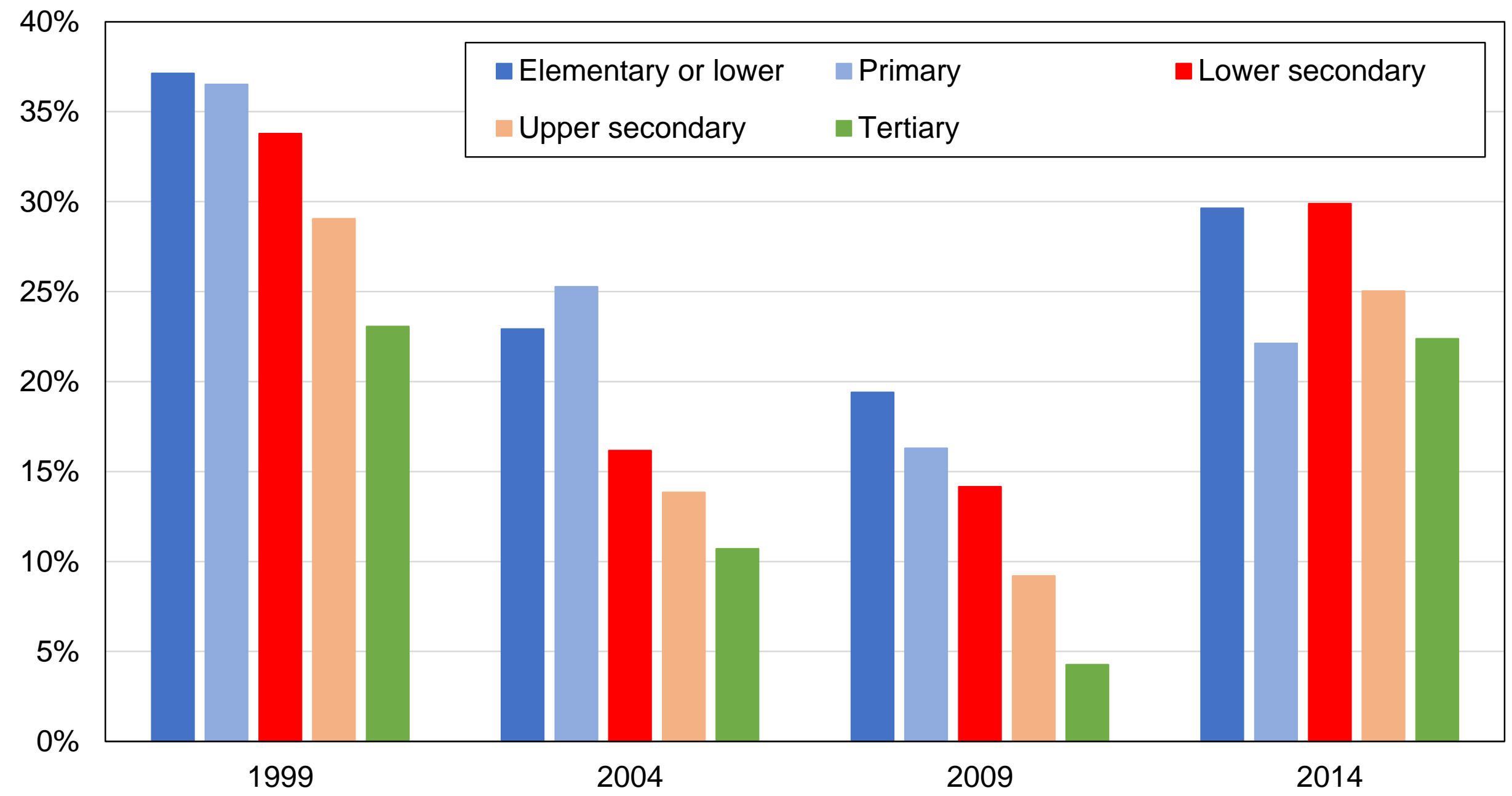

Source: authors' computations using Indonesian political attitudes surveys.

Note: the figure shows the share of votes received by PDI-P/NasDem by education level. 


\section{Figure DC2 - Vote for PDI-P/NasDem among higher-educated voters}

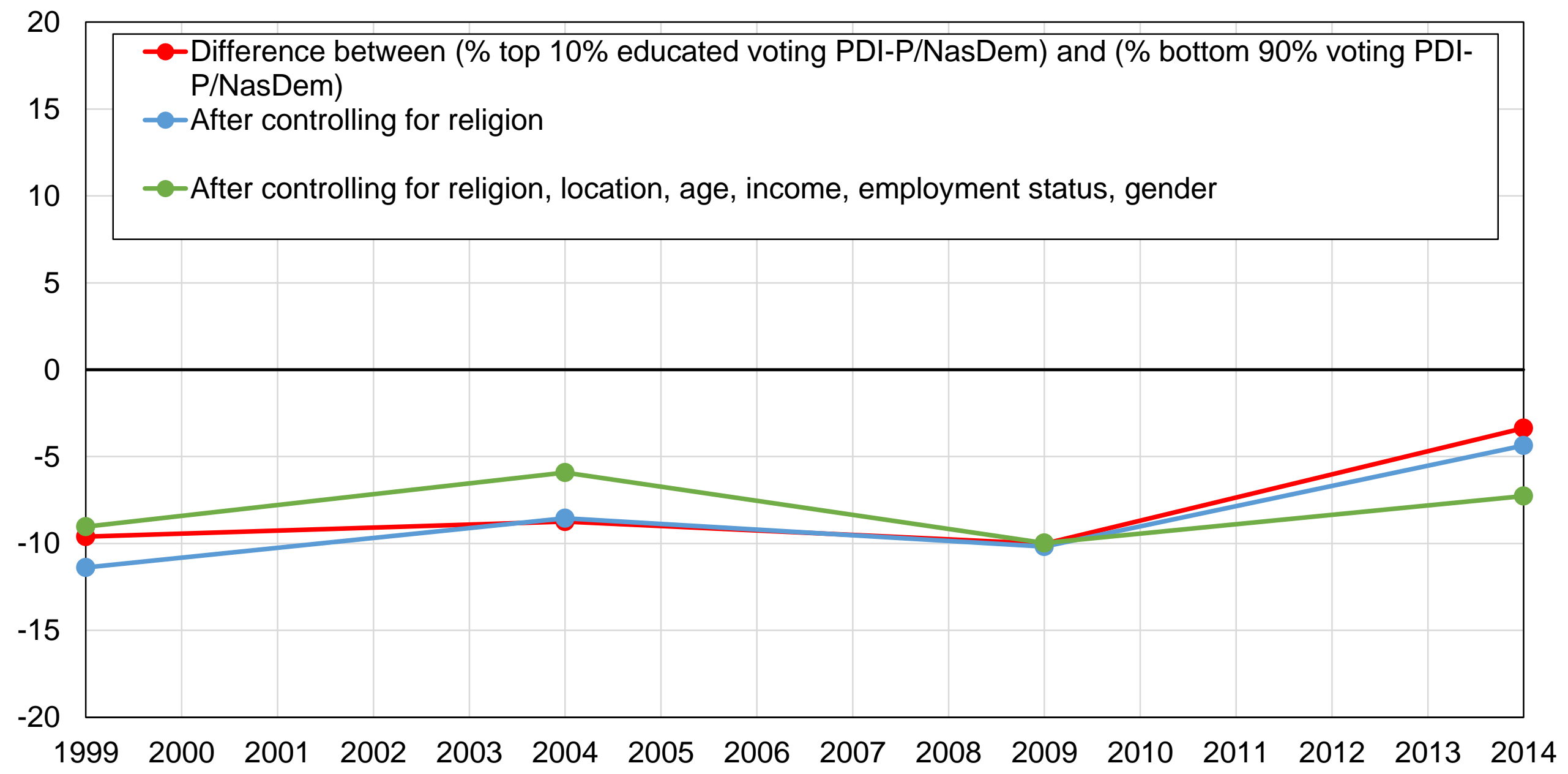

Source: authors' computations using Indonesian political attitudes surveys.

Note: the figure shows the difference between the share of top $10 \%$ educated voters voting for PDI-

$\mathrm{P} / \mathrm{NasDem}$ and the share of other voters voting for these parties, before and after controls. 
Figure DC3 - Vote for PDI-P/NasDem by income group

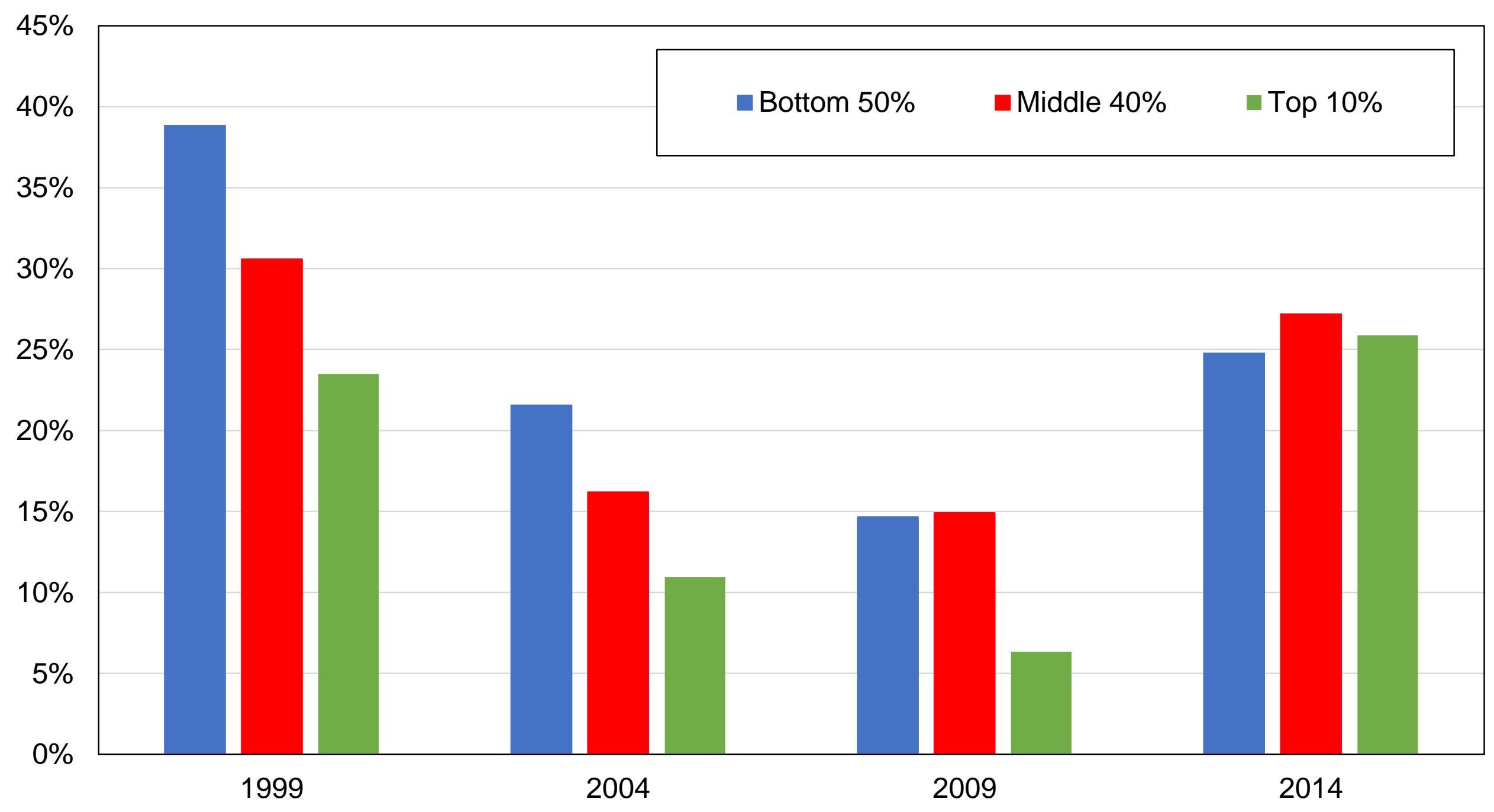

Source: authors' computations using Indonesian political attitudes surveys.

Note: the figure shows the share of votes received by PDI-P/NasDem by income group. 


\section{Figure DC4 - Vote for PDI-P/NasDem among top-income voters}

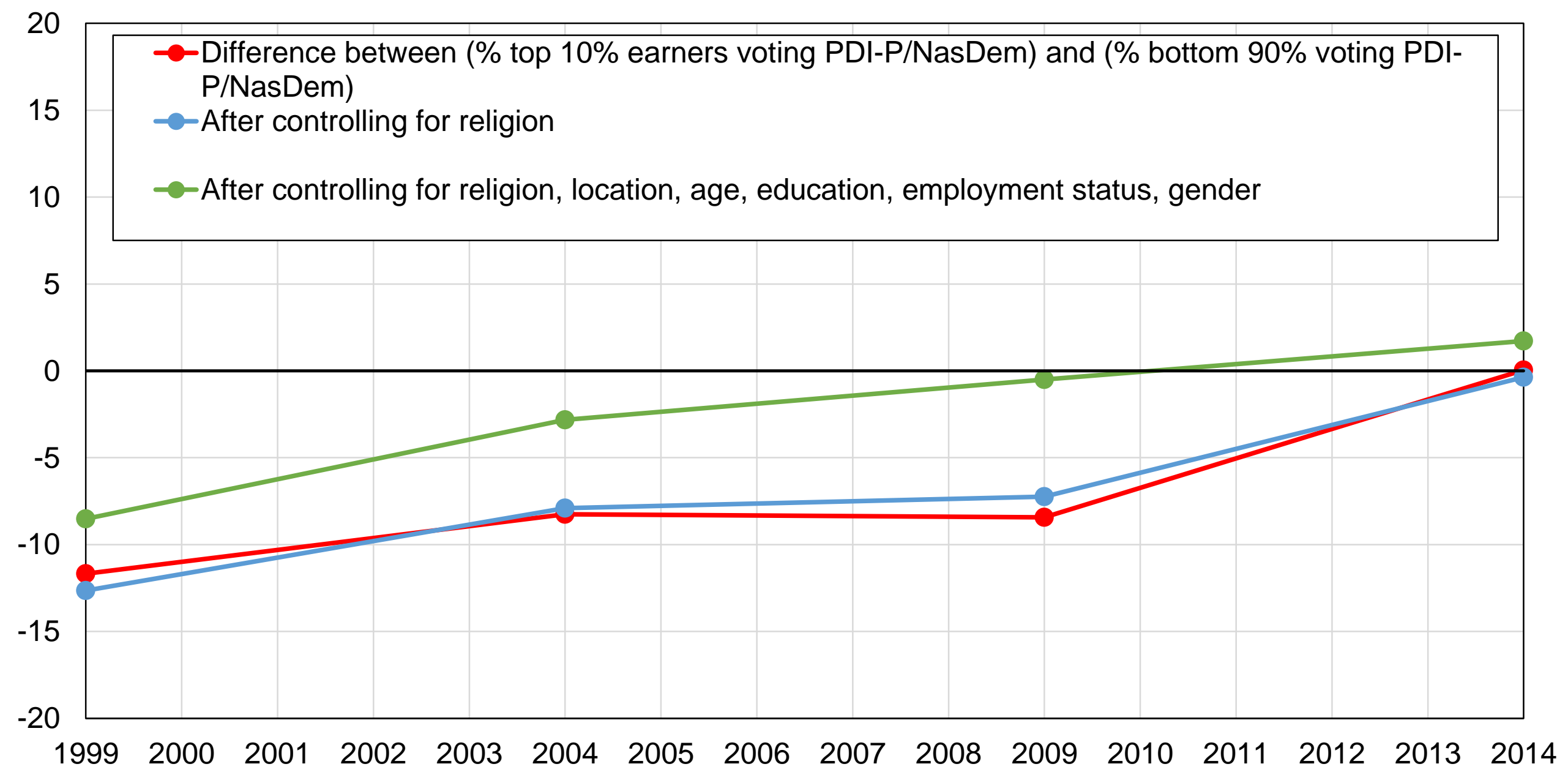

Source: authors' computations using Indonesian political attitudes surveys.

Note: the figure shows the difference between the share of top $10 \%$ earners voting for PDI-P/NasDem and the share of other voters voting for PDI-P/NasDem, before and after controls. 
Figure DC5 - Vote for PDI-P/NasDem by religion

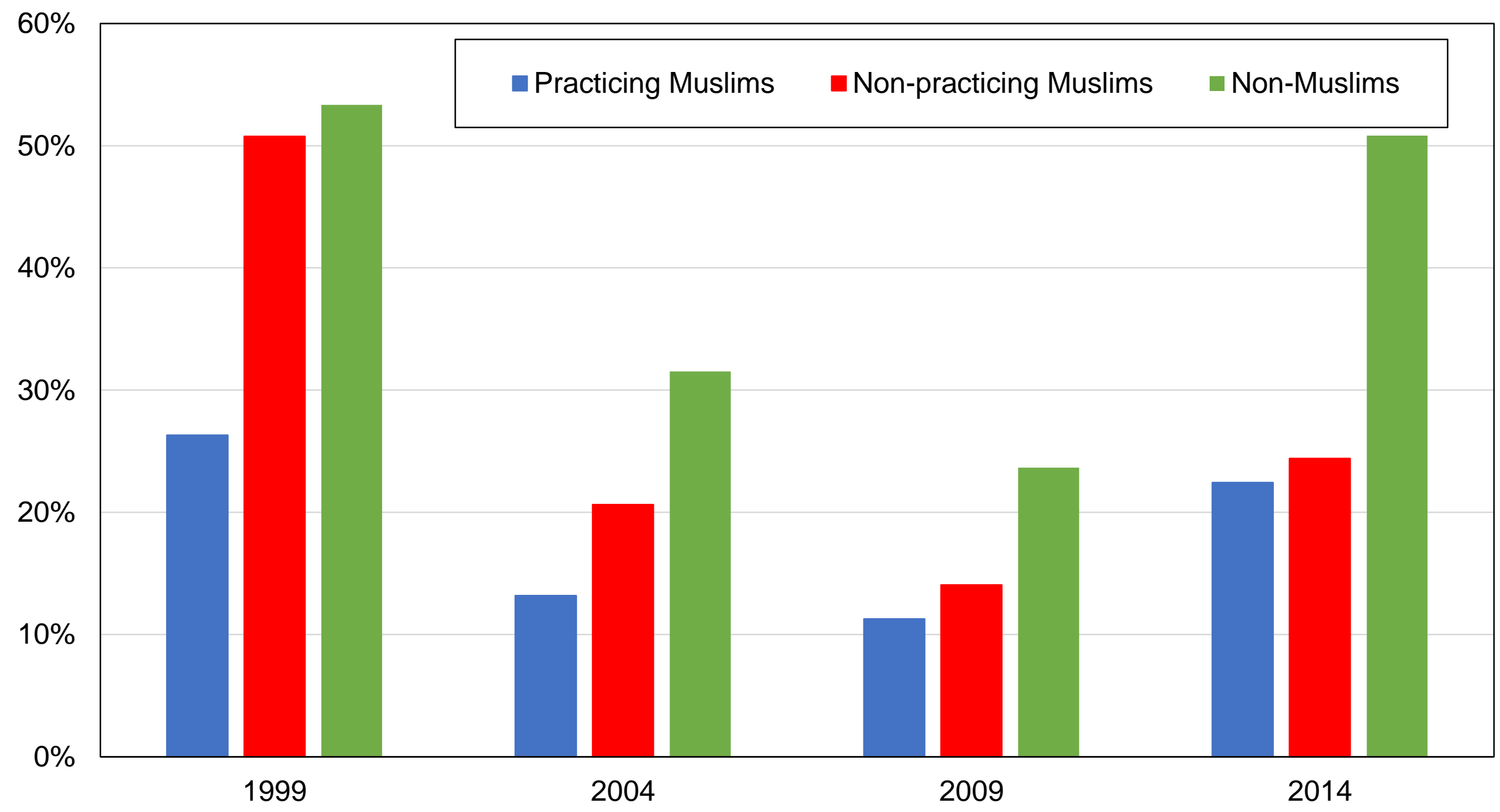

Source: authors' computations using Indonesian political attitudes surveys.

Note: the figure shows the share of votes received by PDI-P/NasDem by religion. 


\section{Figure DC6 - Vote for PDI-P/NasDem among practicing Muslims}

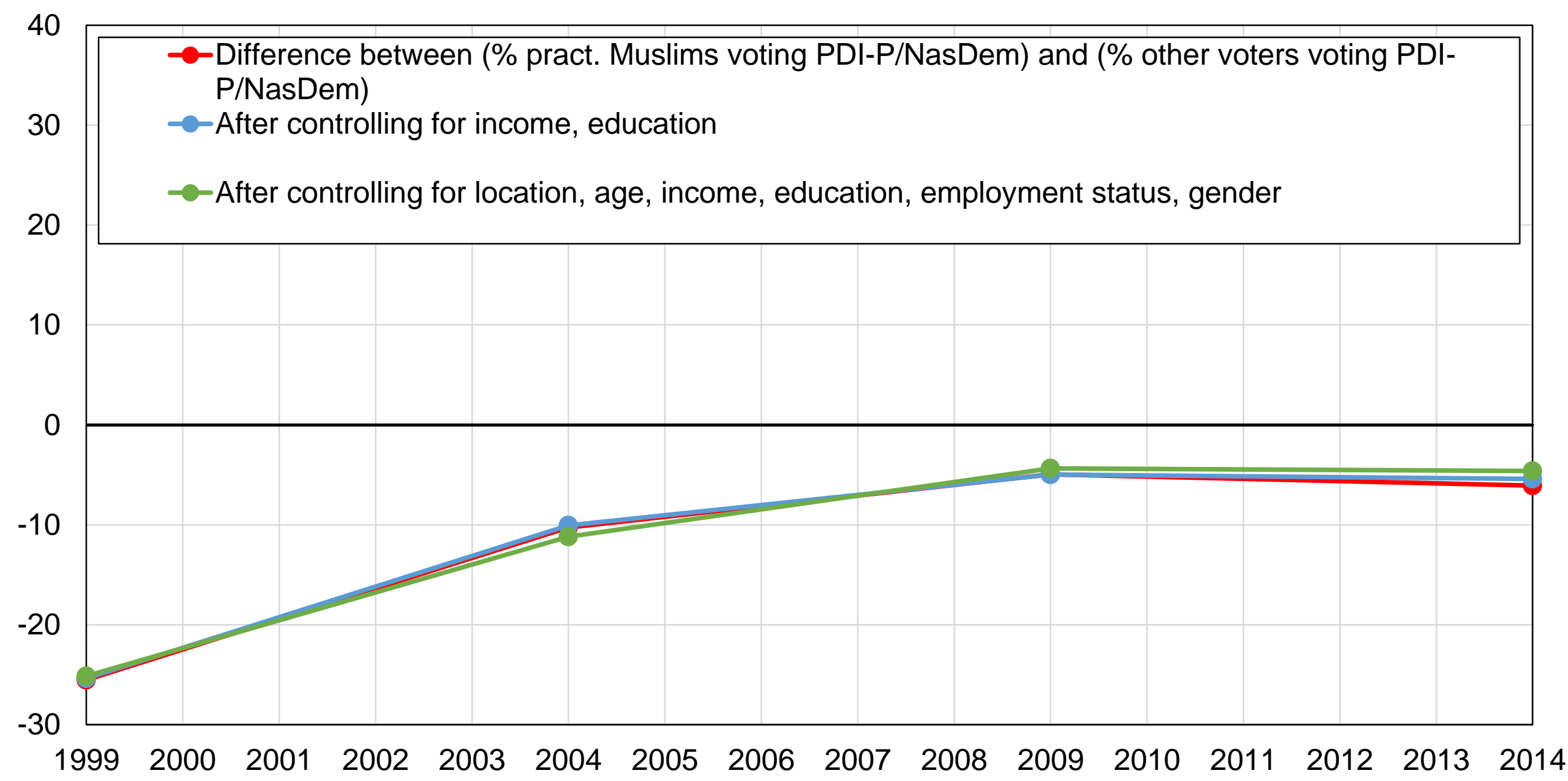

Source: authors' computations using Indonesian political attitudes surveys.

Note: the figure shows the difference between the share of practicing Muslims voting for PDI-P/NasDem and the share of other voters voting for PDI-P/NasDem, before and after controls. 
Figure DC7 - Vote for PDI-P/NasDem by age group

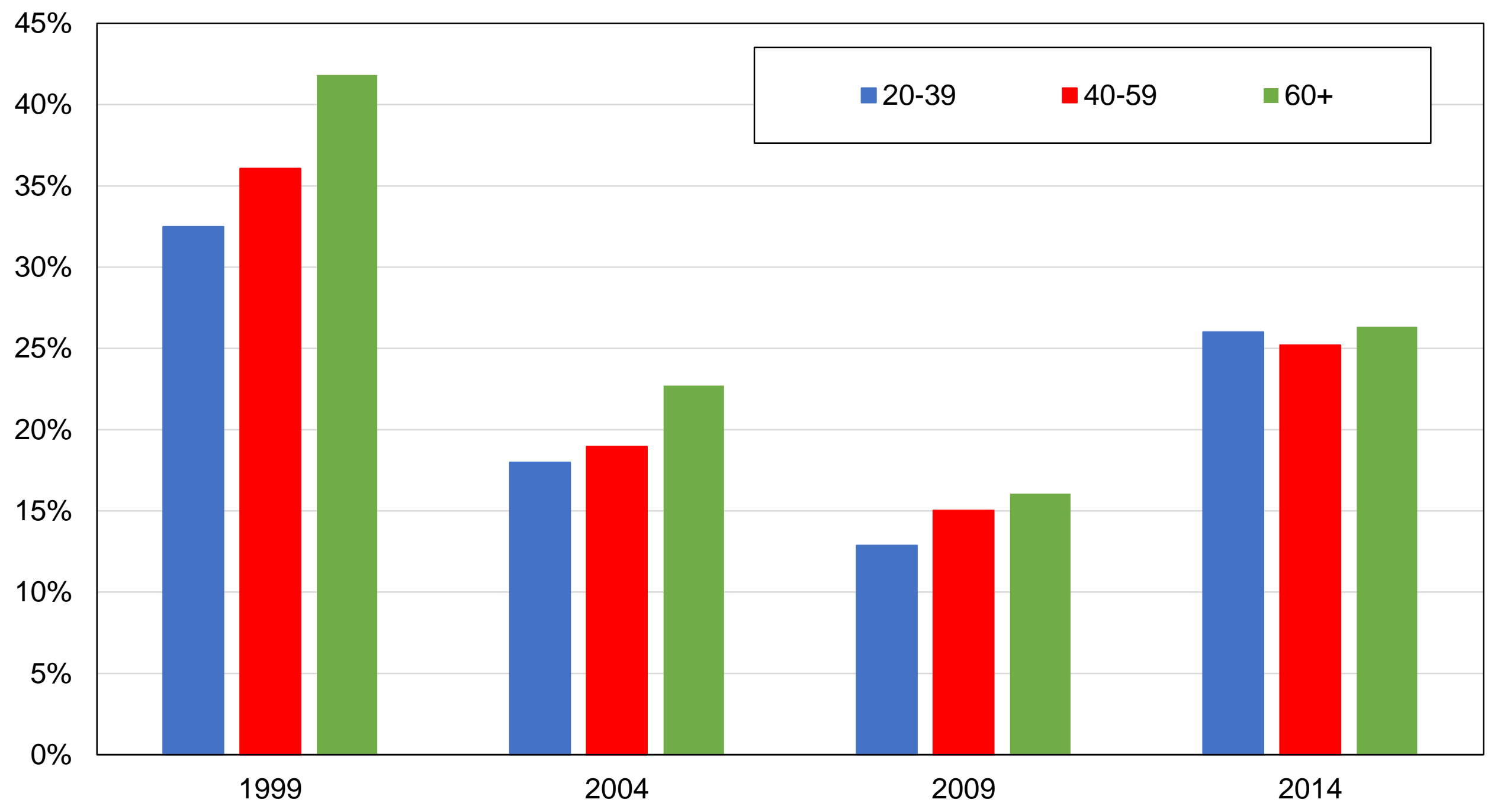

Source: authors' computations using Indonesian political attitudes surveys.

Note: the figure shows the share of votes received by PDI-P/NasDem by age group. 


\section{Figure DC8 - Vote for PDI-P/NasDem among young voters}

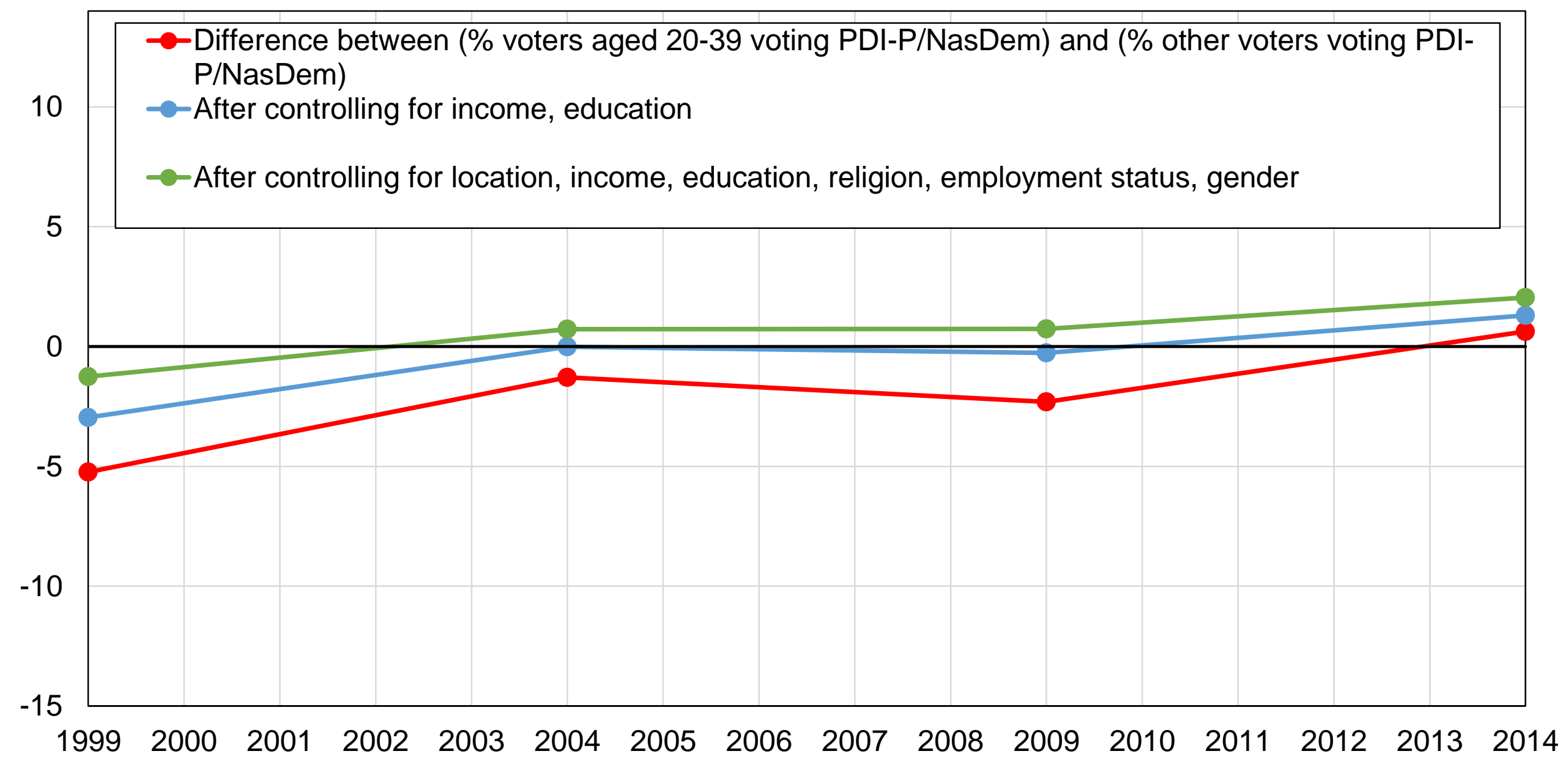

Source: authors' computations using Indonesian political attitudes surveys.

Note: the figure shows the difference between the share of voters aged 20 to 39 voting for PDI-P/NasDem and the share of other voters voting for PDI-P/NasDem, before and after controls. 
Figure DC9 - Vote for PDI-P/NasDem by rural-urban location

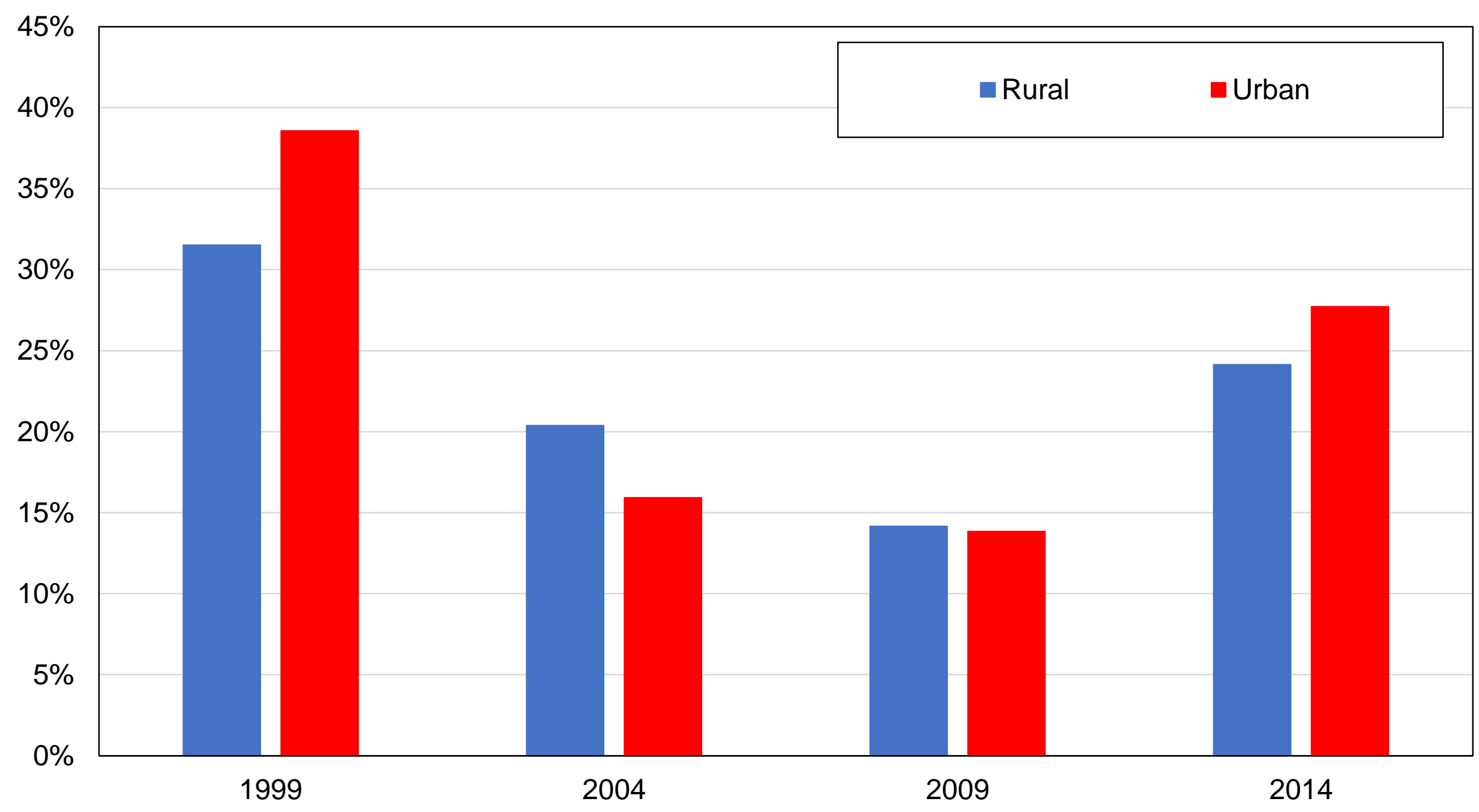

Source: authors' computations using Indonesian political attitudes surveys.

Note: the figure shows the share of votes received by PDI-P/NasDem by rural-urban location. 


\section{Figure DC10 - Vote for PDI-P/NasDem among urban voters}

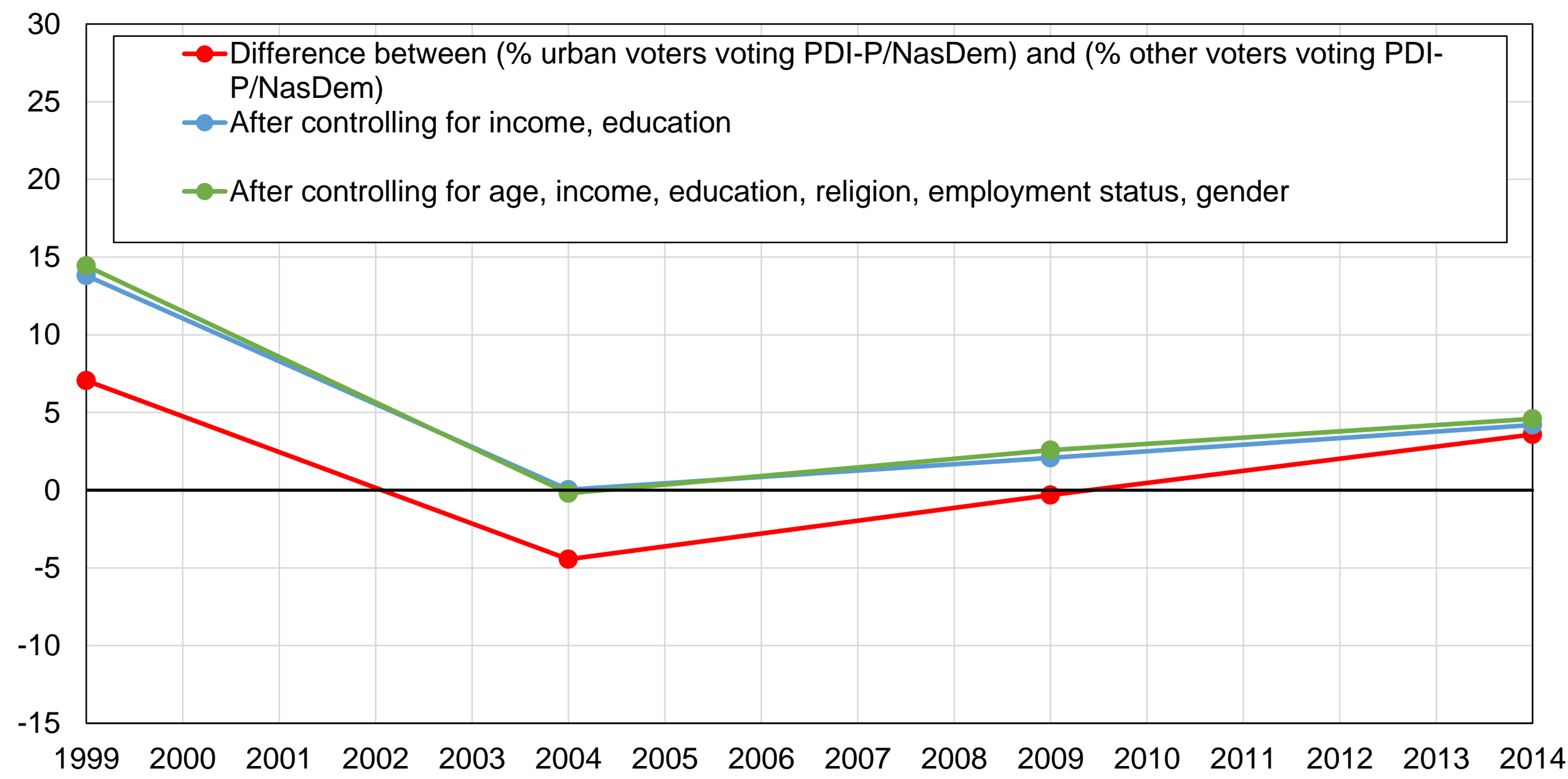

Source: authors' computations using Indonesian political attitudes surveys.

Note: the figure shows the difference between the share of urban voters voting for PDI-P/NasDem and the share of other voters voting for PDI-P/NasDem, before and after controls. 
Figure DC11 - Vote for PDI-P/NasDem by ethnicity

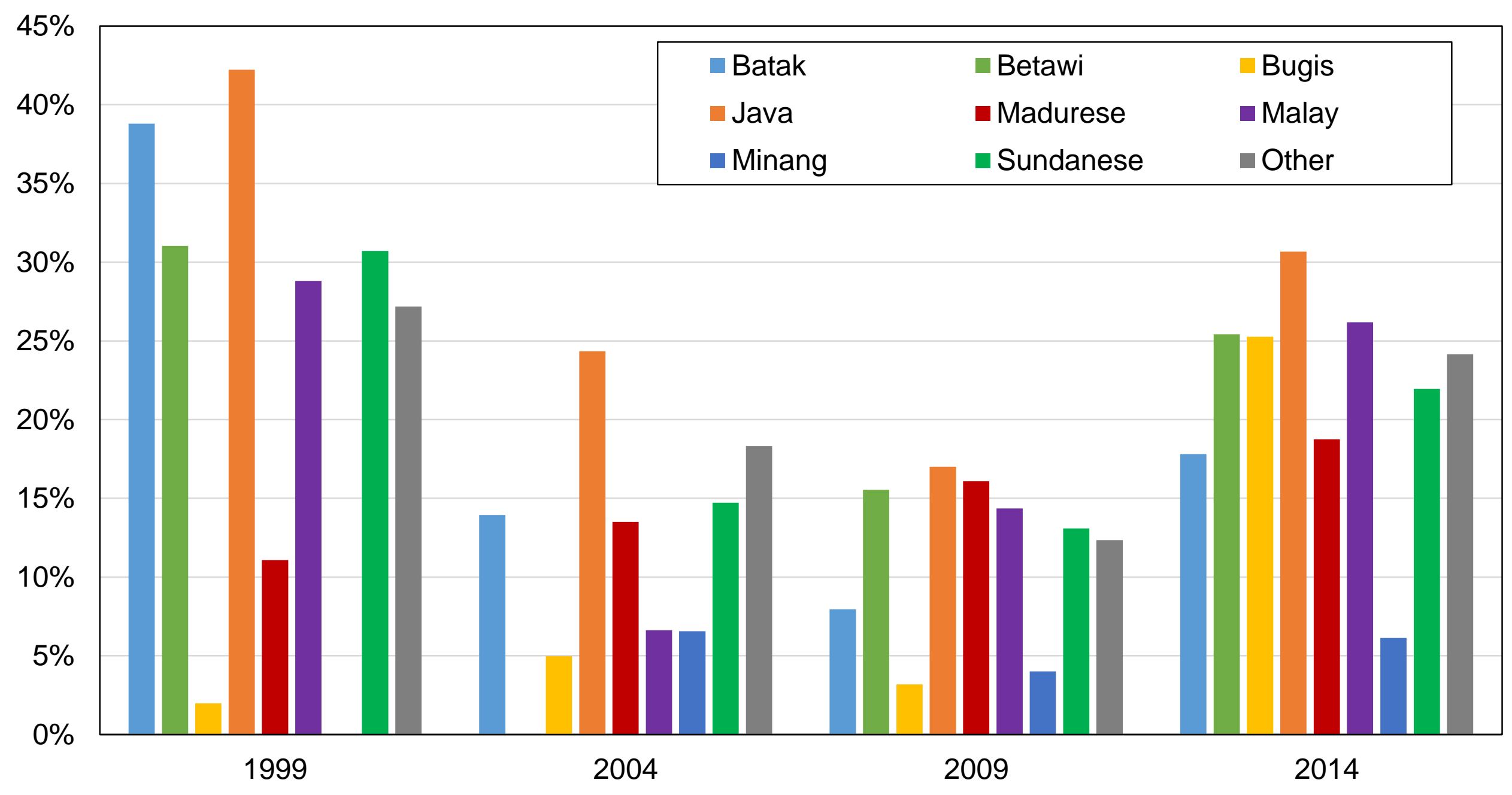

Source: authors' computations using Indonesian political attitudes surveys.

Note: the figure shows the share of votes received by PDI-P/NasDem by ethnic affiliation. 


\section{Figure DC12 - Vote for PDI-P/NasDem among Javanese voters}

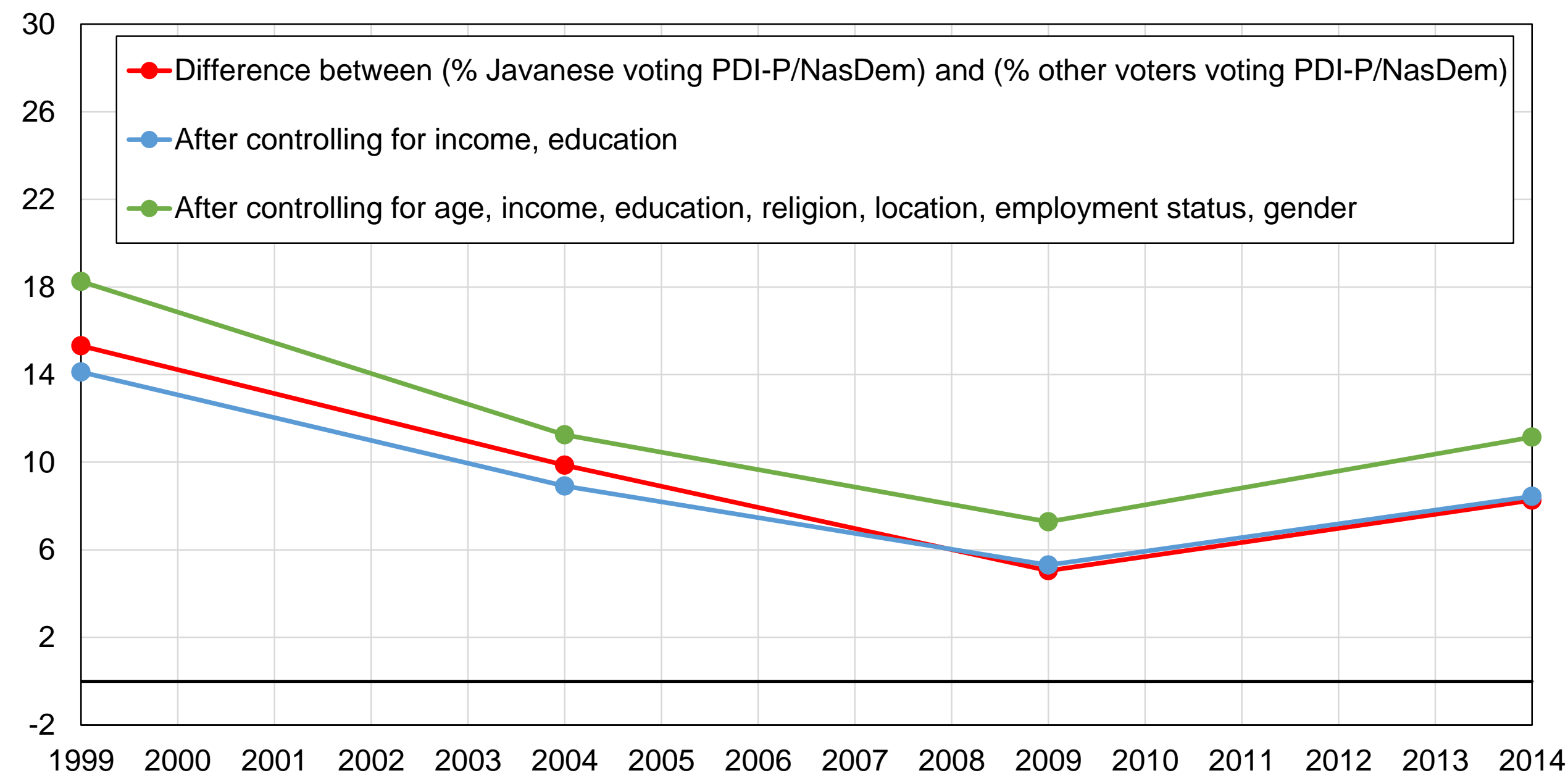

Source: authors' computations using Indonesian political attitudes surveys.

Note: the figure shows the difference between the share of Javanese voters voting for PDI-P/NasDem and the share of other voters voting for PDI-P/NasDem, before and after controls. 


\section{Figure DD1 - Vote for Islamic parties by education level}

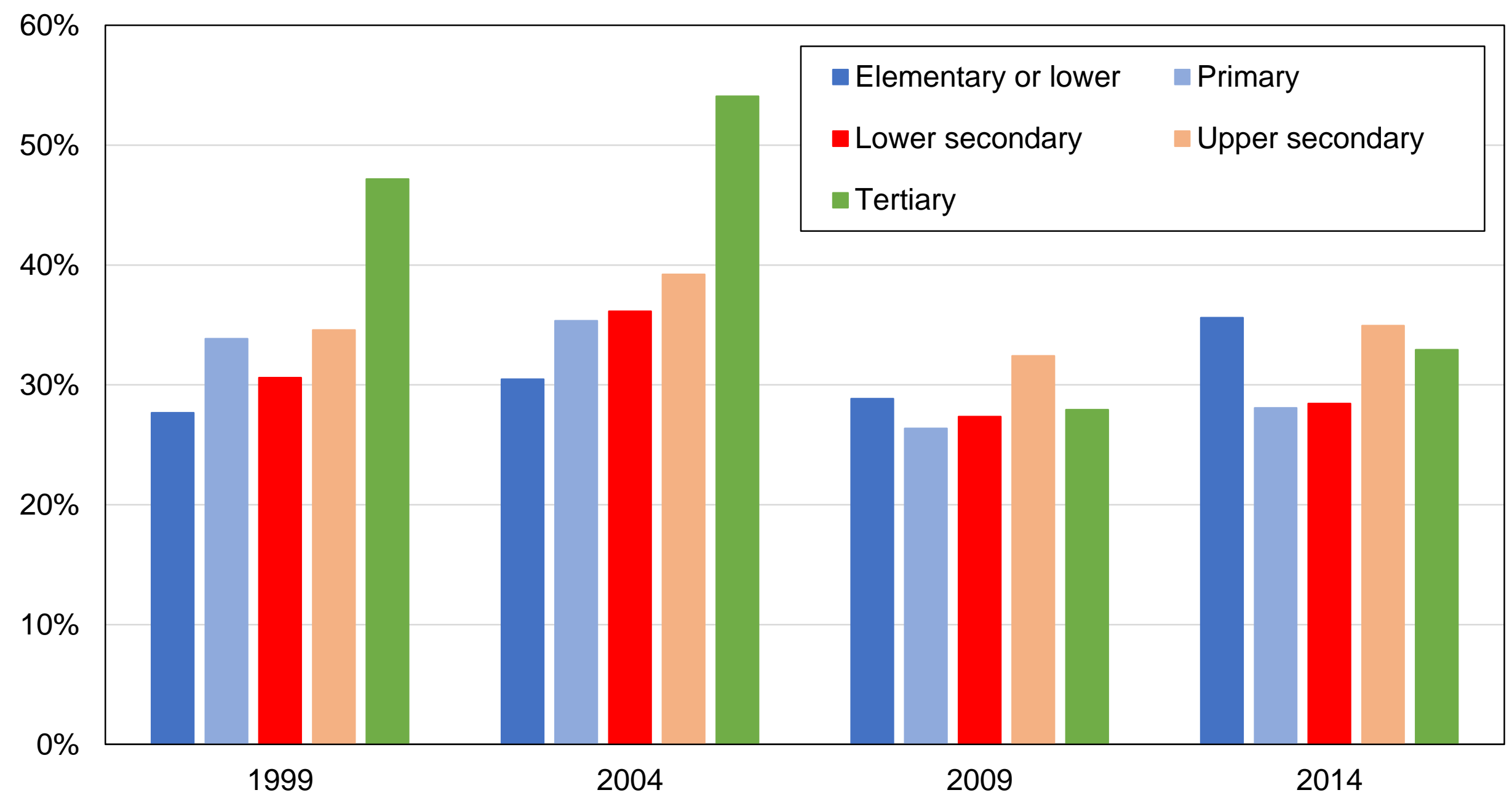

Source: authors' computations using Indonesian political attitudes surveys.

Note: the figure shows the share of votes received by Islamic parties by education level. 


\section{Figure DD2 - Vote for Islamic parties among higher-educated voters}

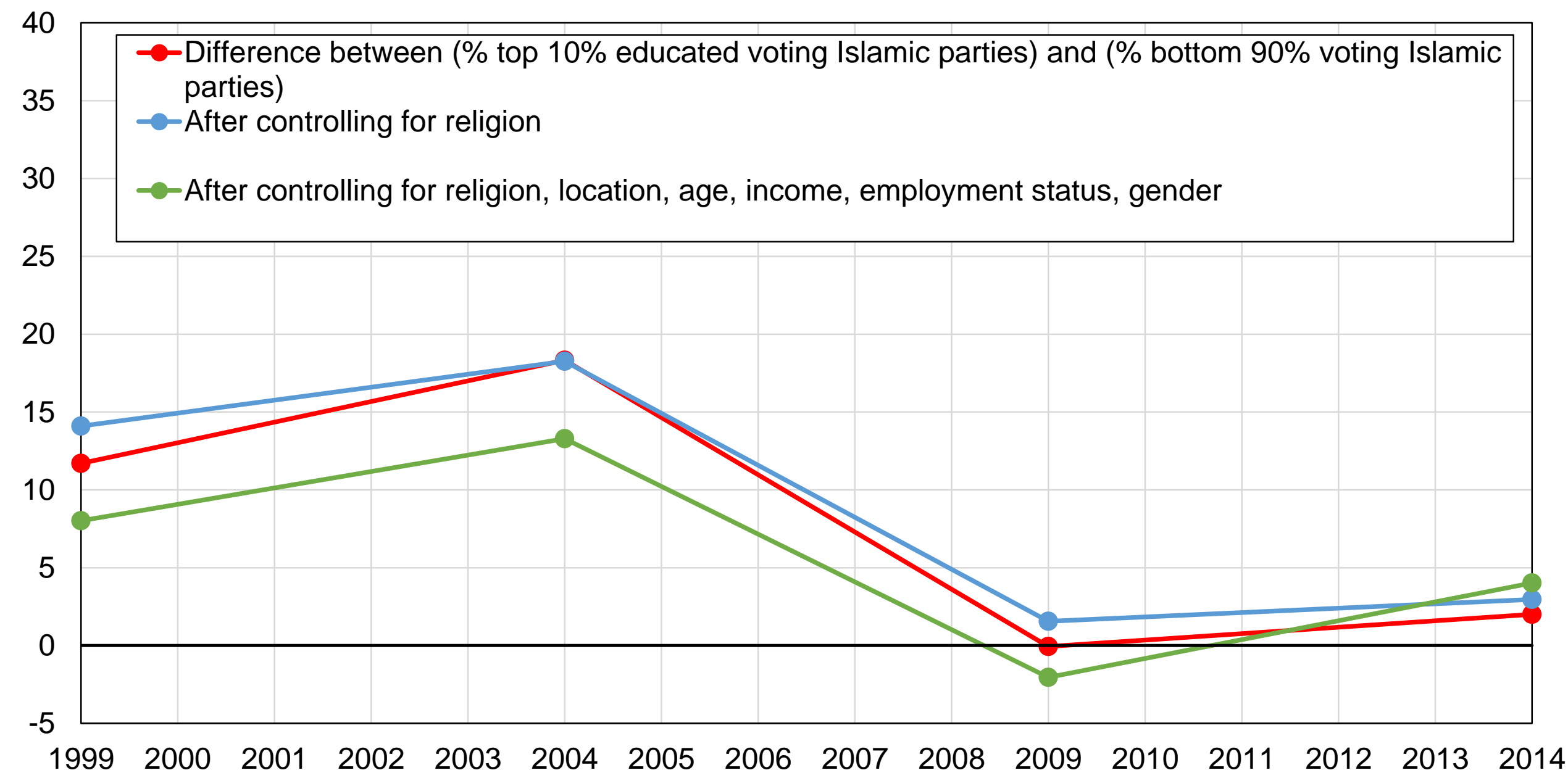

Source: authors' computations using Indonesian political attitudes surveys.

Note: the figure shows the difference between the share of top $10 \%$ educated voters voting for Islamic parties and the share of other voters voting for Islamic parties, before and after controls. 
Figure DD3 - Vote for Islamic parties by income group

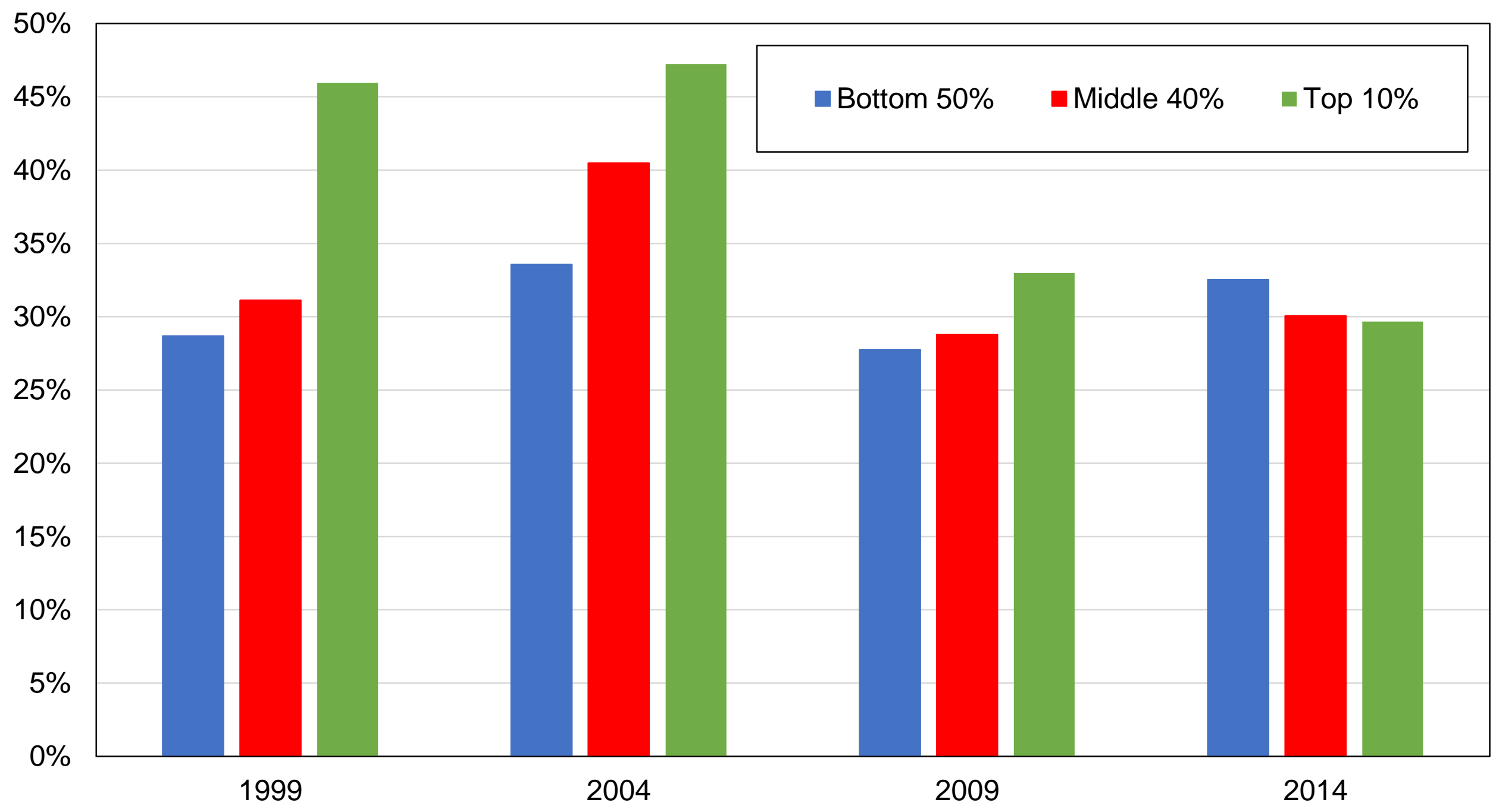

Source: authors' computations using Indonesian political attitudes surveys.

Note: the figure shows the share of votes received by Islamic parties by income group. 


\section{Figure DD4 - Vote for Islamic parties among top-income voters}

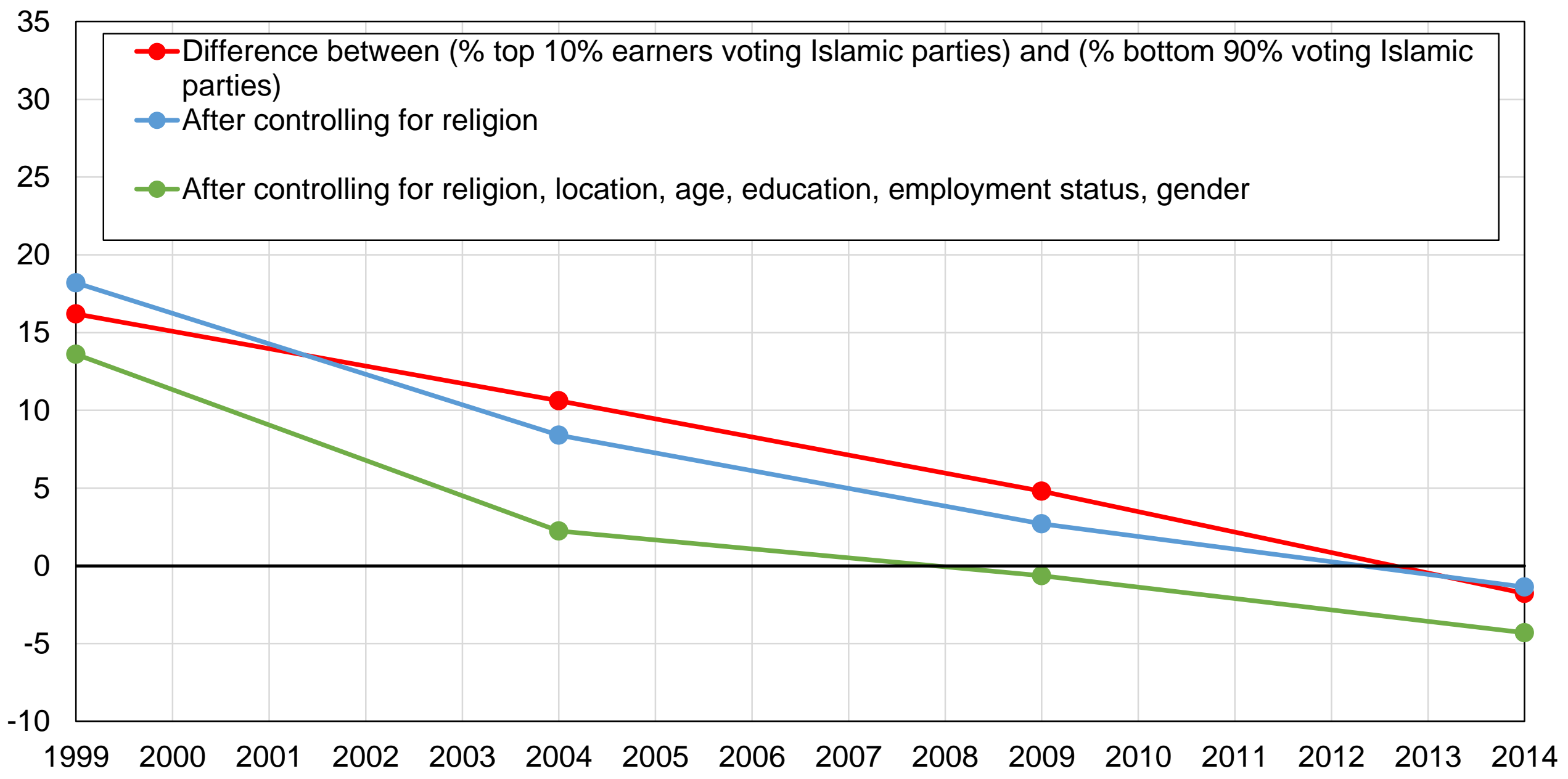

Source: authors' computations using Indonesian political attitudes surveys.

Note: the figure shows the difference between the share of top $10 \%$ earners voting for Islamic parties and the share of other voters voting for Islamic parties, before and after controls. 
Figure DD5 - Vote for Islamic parties by religion

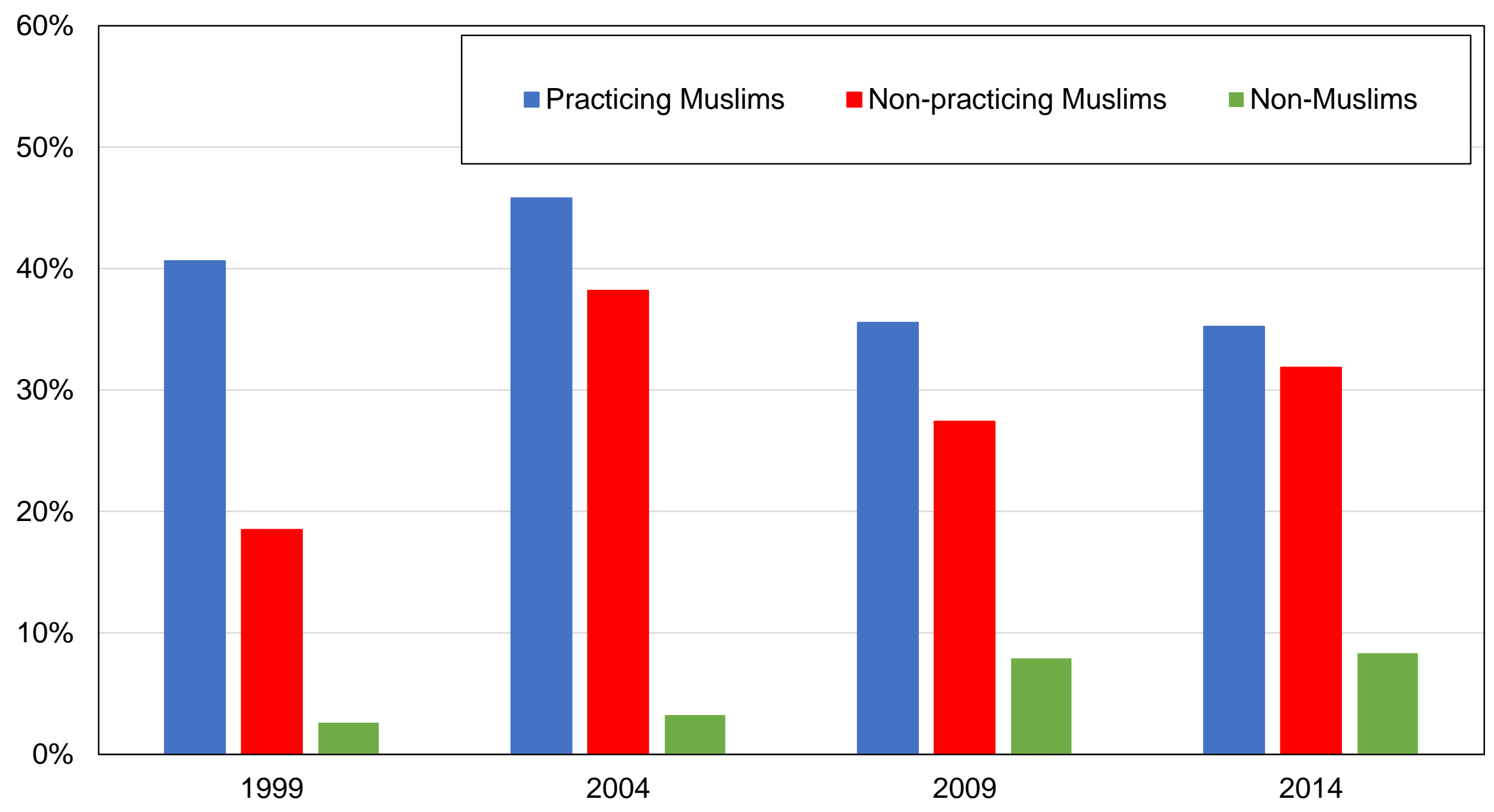

Source: authors' computations using Indonesian political attitudes surveys.

Note: the figure shows the share of votes received by Islamic parties by religion. 


\section{Figure DD6 - Vote for Islamic parties among practicing Muslims}

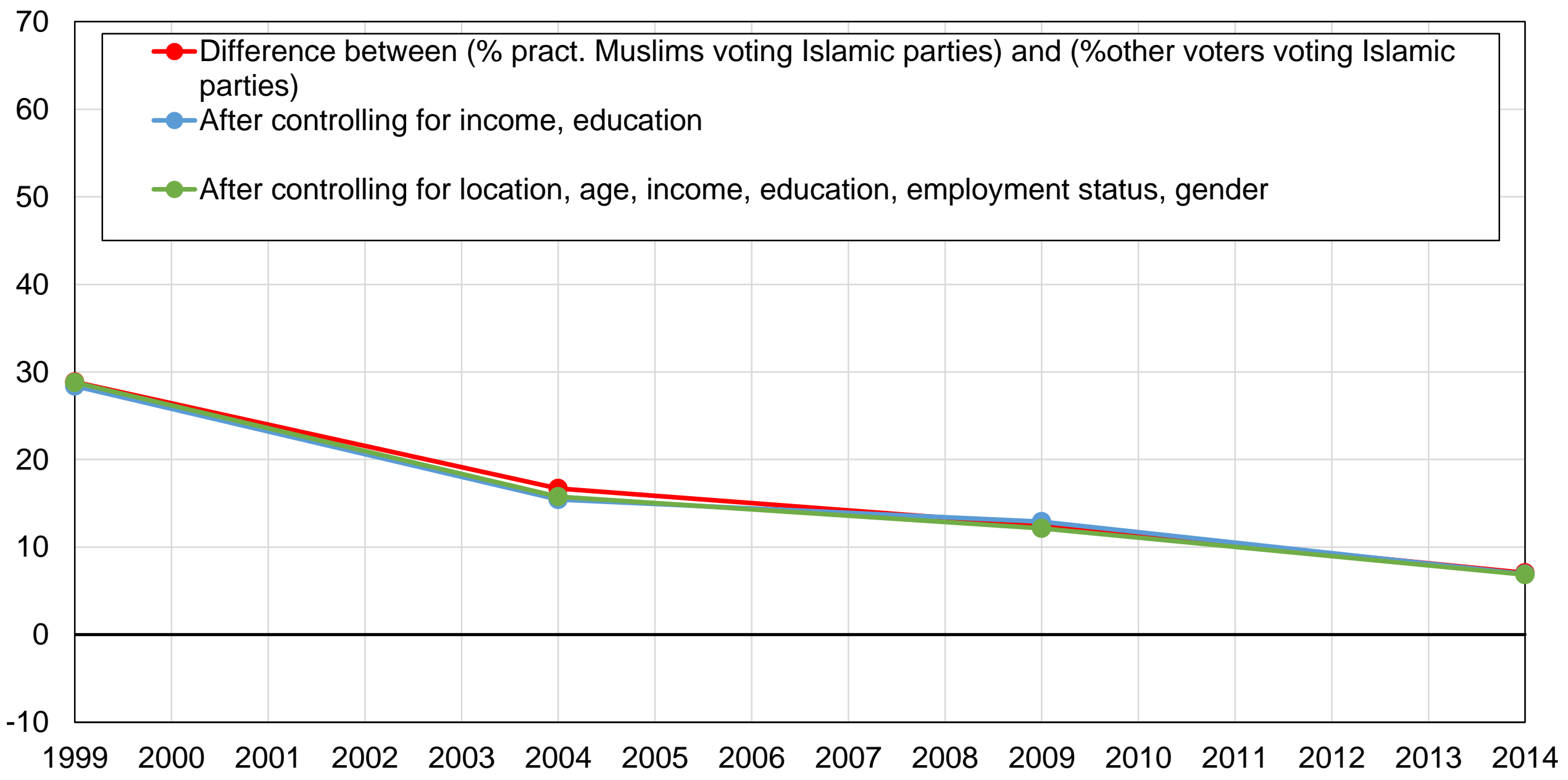

Source: authors' computations using Indonesian political attitudes surveys.

Note: the figure shows the difference between the share of practicing Muslims voting for Islamic parties and the share of other voters voting for Islamic parties, before and after controls. 
Figure DD7 - Vote for Islamic parties by age group

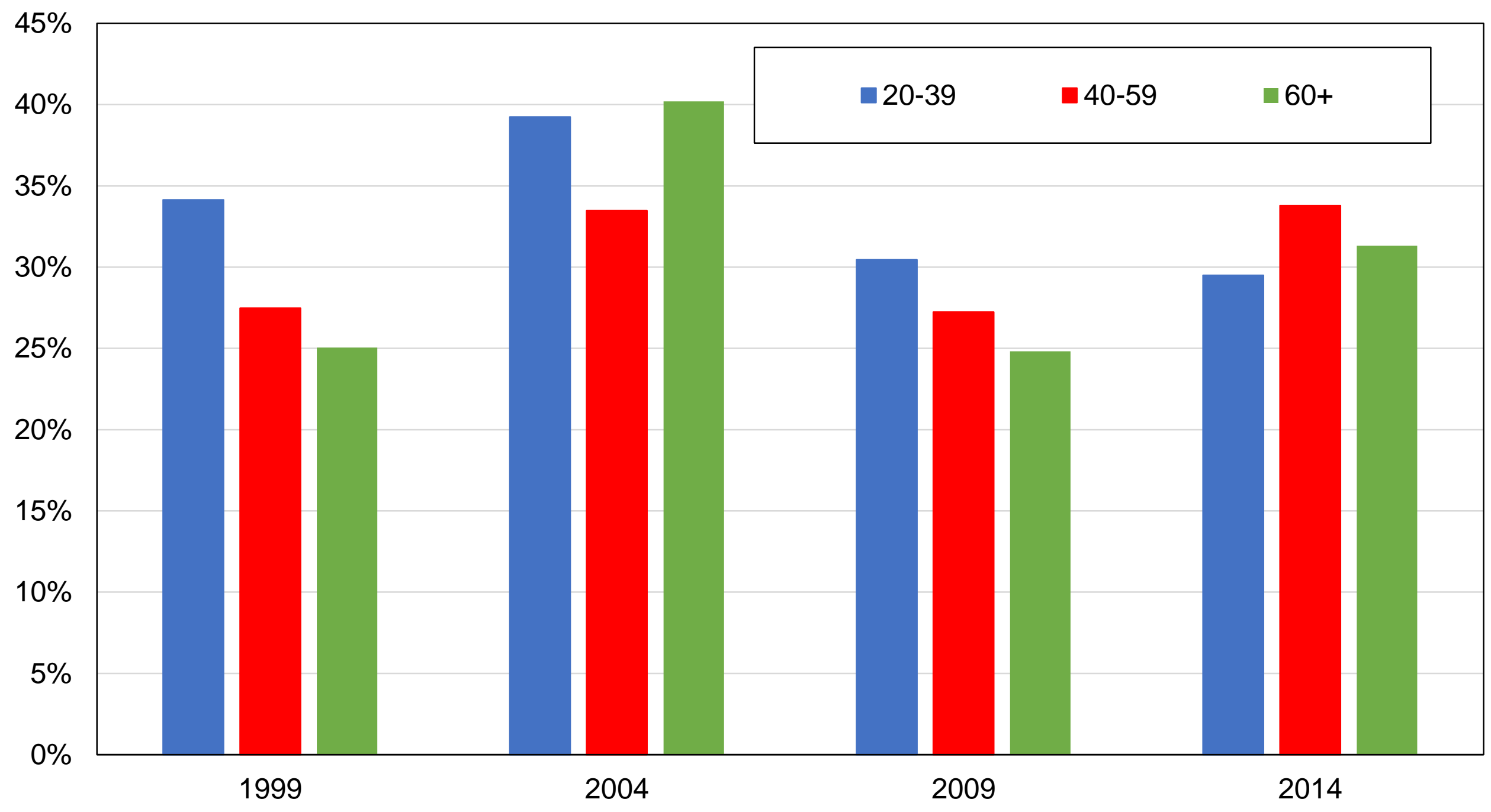

Source: authors' computations using Indonesian political attitudes surveys.

Note: the figure shows the share of votes received by Islamic parties by age group. 


\section{Figure DD8 - Vote for Islamic parties among young voters}

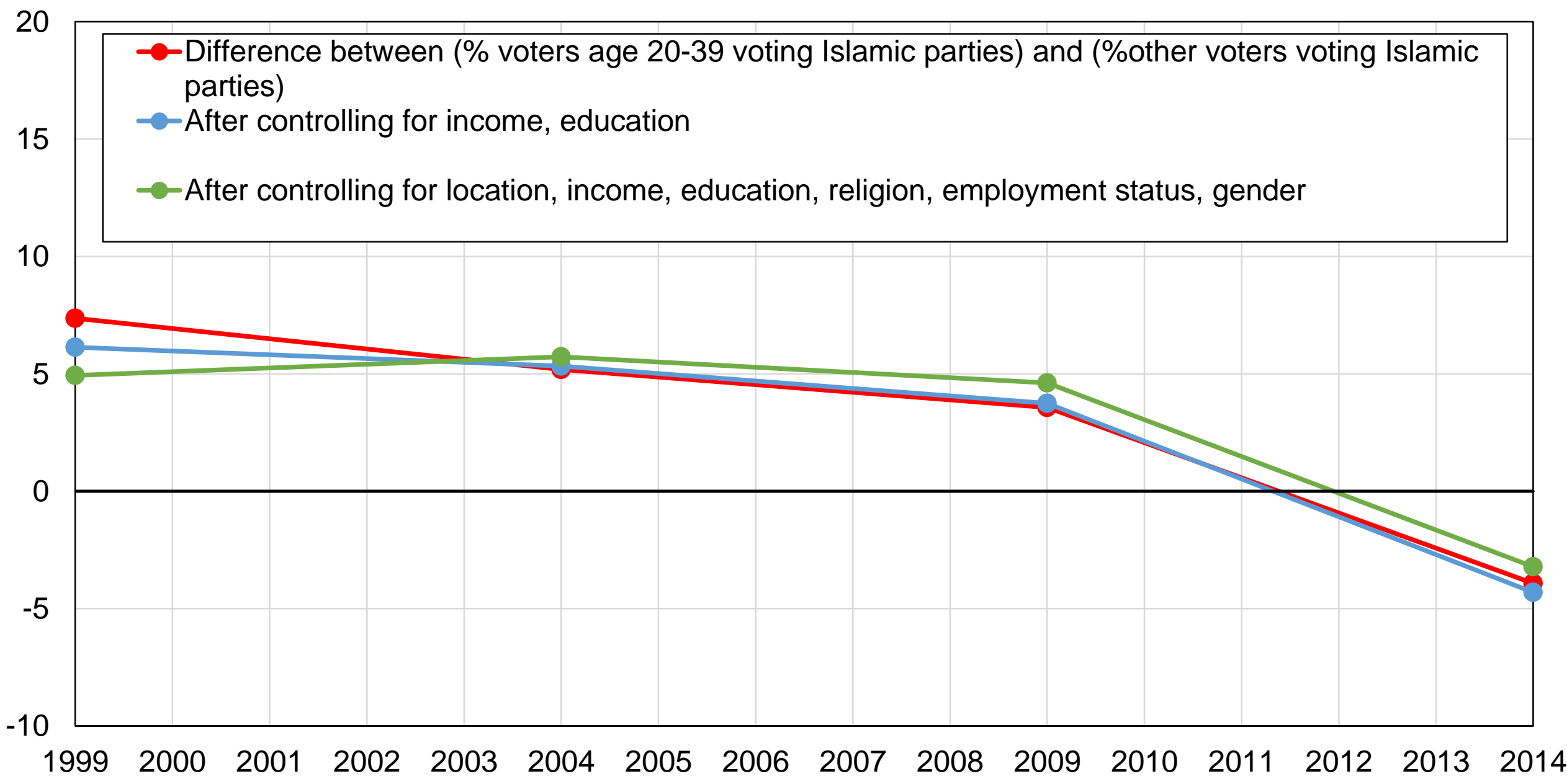

Source: authors' computations using Indonesian political attitudes surveys.

Note: the figure shows the difference between the share of voters aged 20 to 39 voting for Islamic parties and the share of other voters voting for Islamic parties, before and after controls. 
Figure DD9 - Vote for Islamic parties by rural-urban location

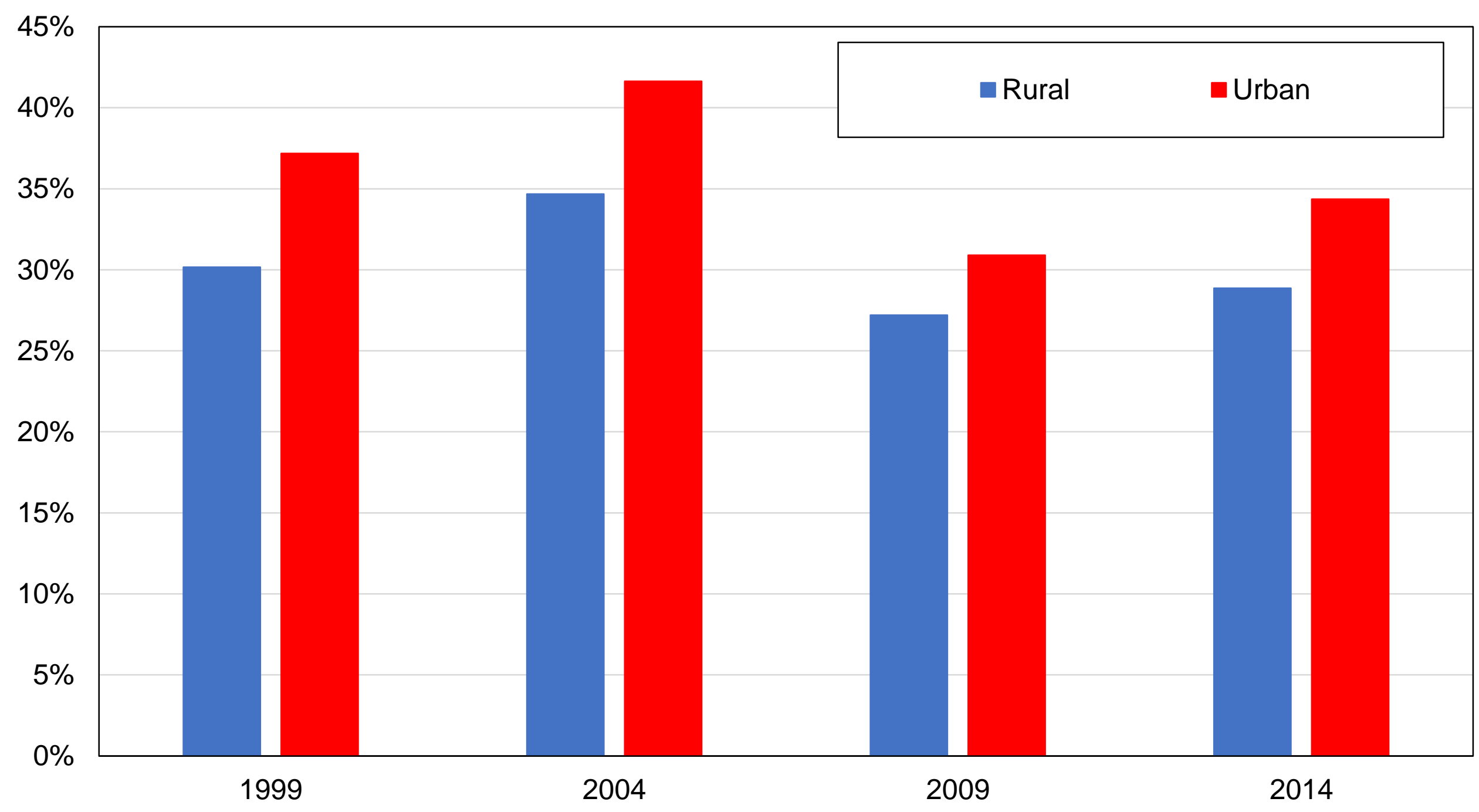

Source: authors' computations using Indonesian political attitudes surveys.

Note: the figure shows the share of votes received by Islamic parties by rural-urban location. 


\section{Figure DD10 - Vote for Islamic parties among urban voters}

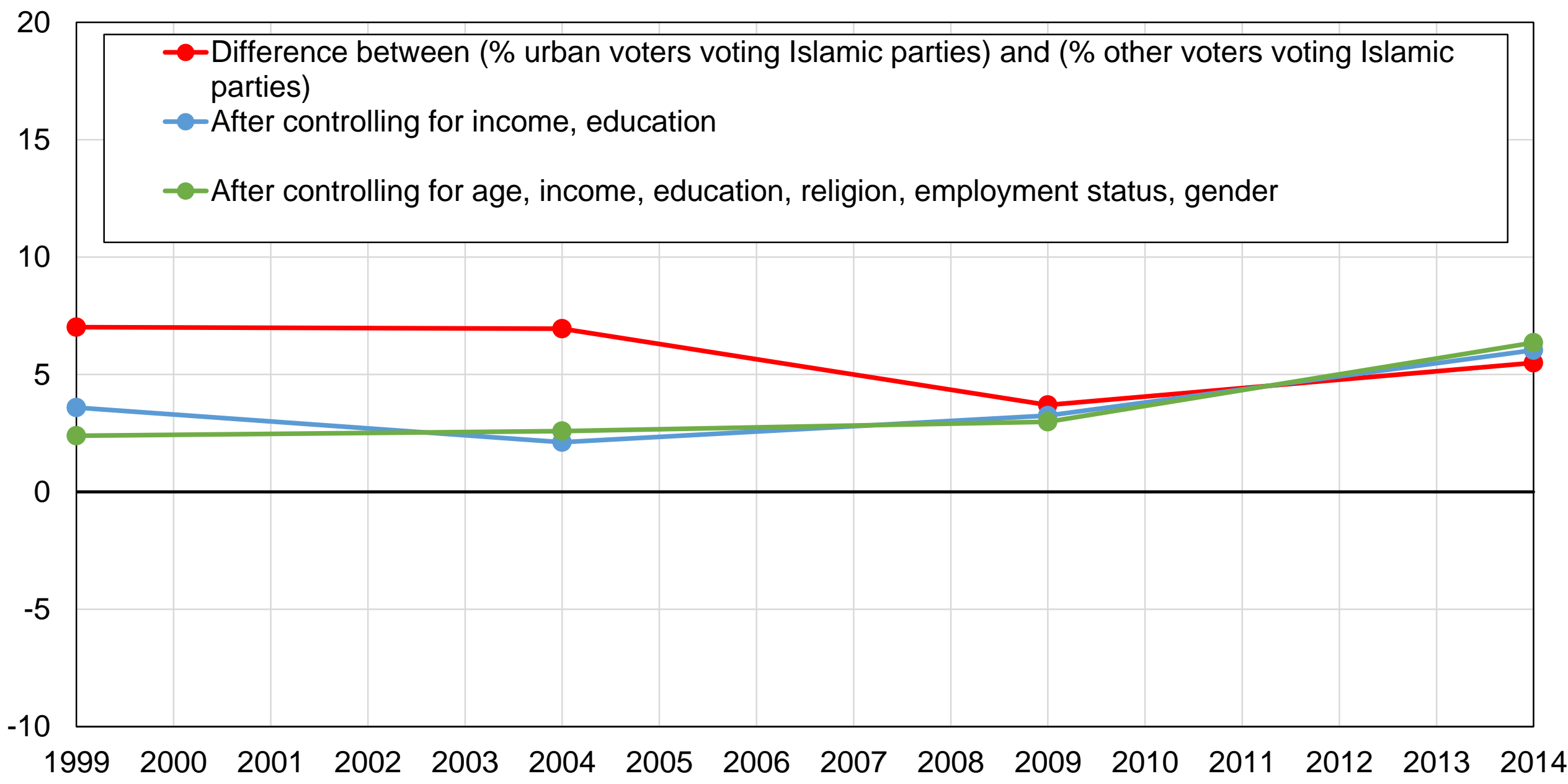

Source: authors' computations using Indonesian political attitudes surveys.

Note: the figure shows the difference between the share of urban voters voting for Islamic parties and the share of other voters voting for Islamic parties, before and after controls. 
Figure DD11 - Vote for Islamic parties by ethnicity

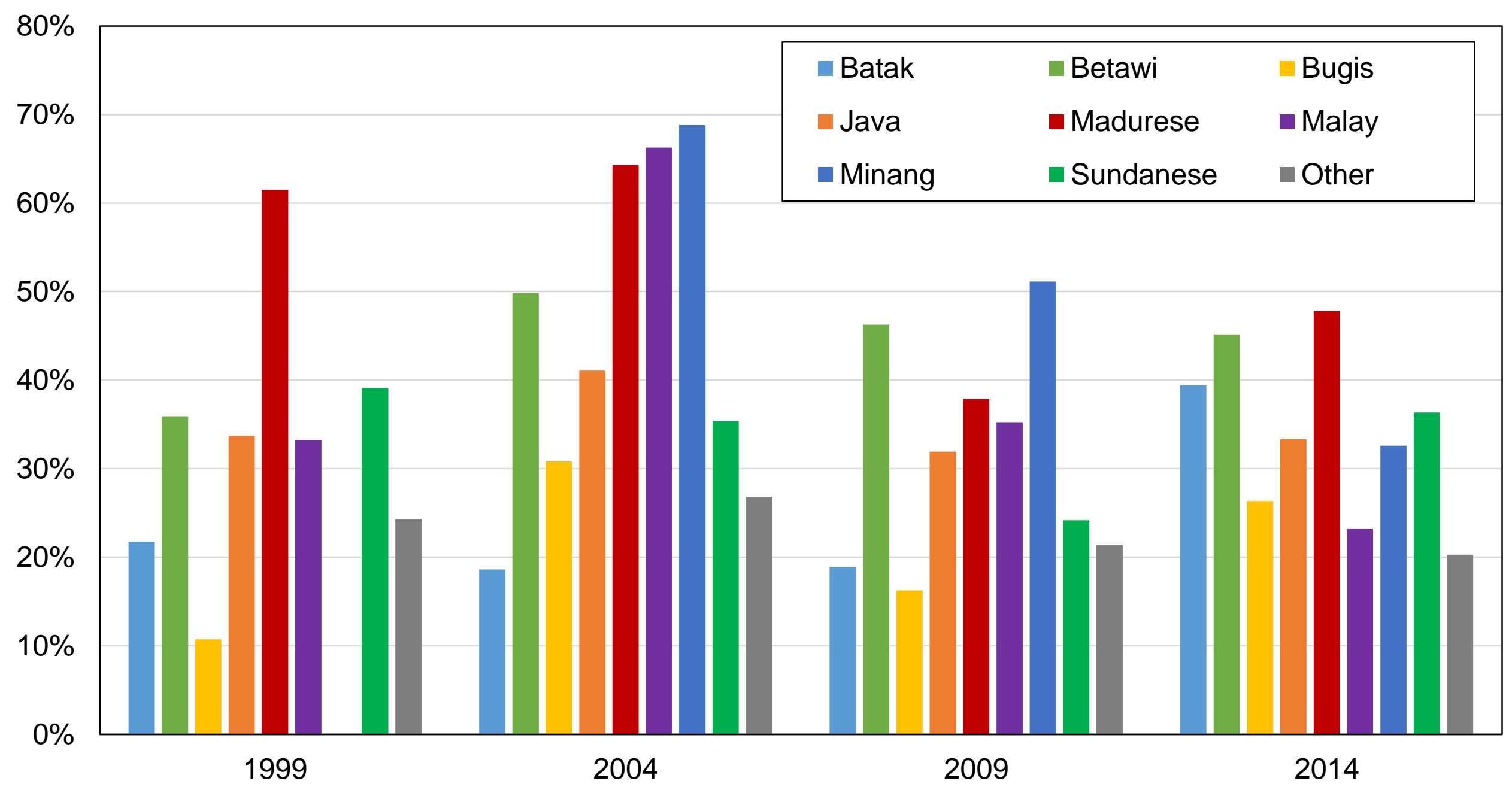

Source: authors' computations using Indonesian political attitudes surveys.

Note: the figure shows the share of votes received by Islamic parties by ethnic affiliation. 


\section{Figure DD12 - Vote for Islamic parties among Javanese voters}

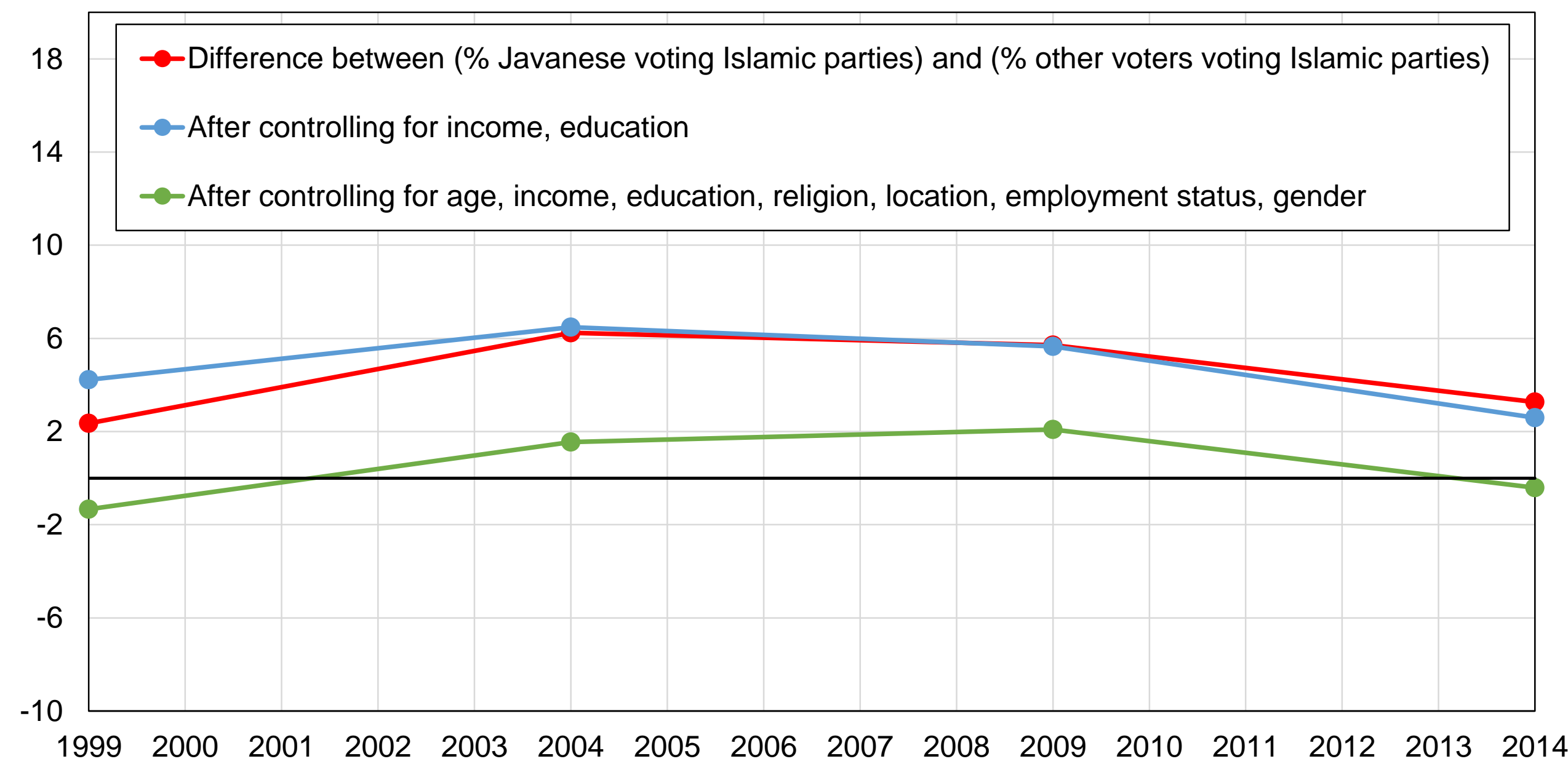

Source: authors' computations using Indonesian political attitudes surveys.

Note: the figure shows the difference between the share of Javanese voters voting for Islamic parties and the share of other voters voting for Islamic parties, before and after controls. 
Figure DE1 - Vote for PD by education level

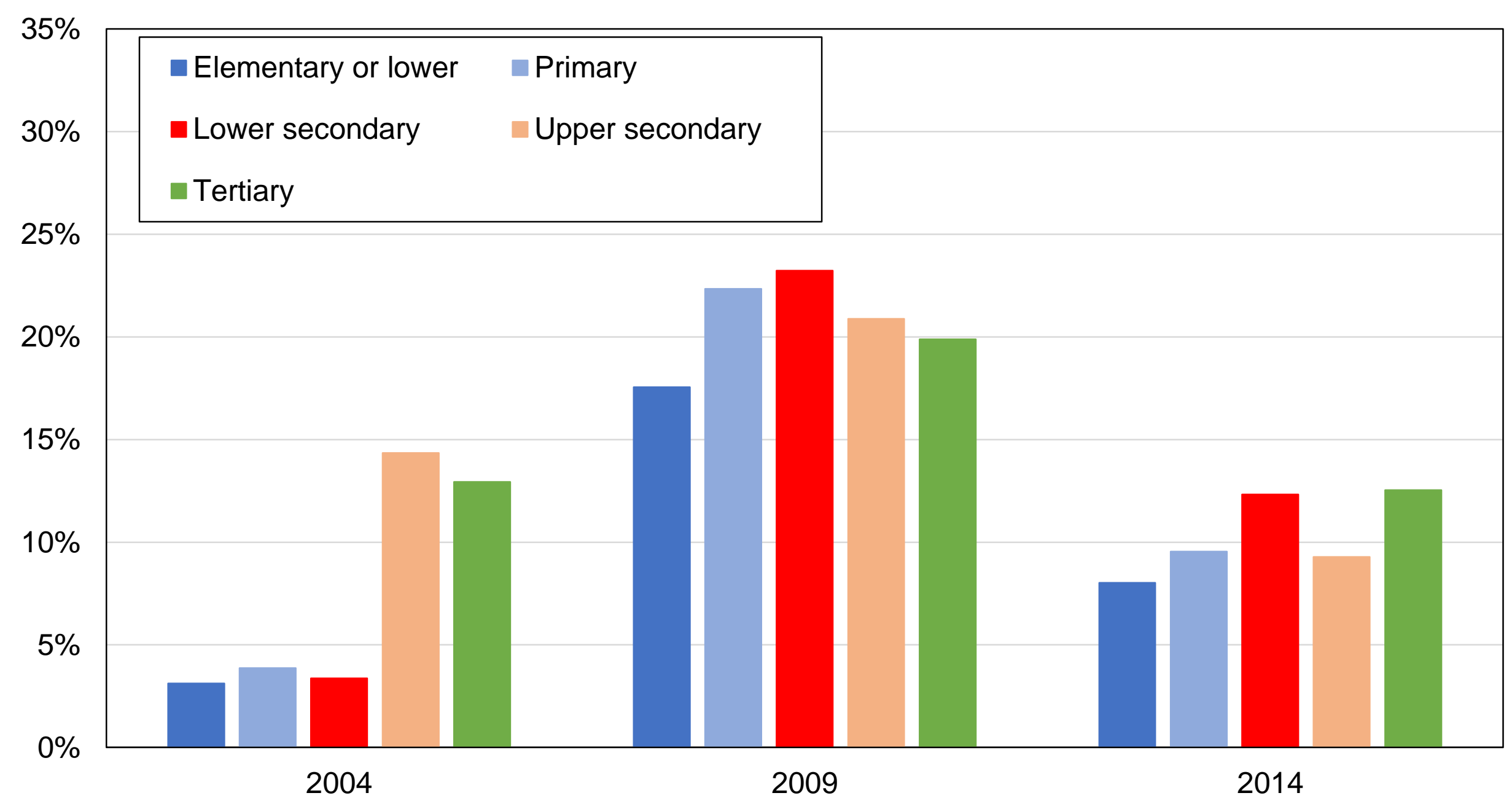

Source: authors' computations using Indonesian political attitudes surveys.

Note: the figure shows the share of votes received by PD by education level. 


\section{Figure DE2 - Vote for PD among higher-educated voters}

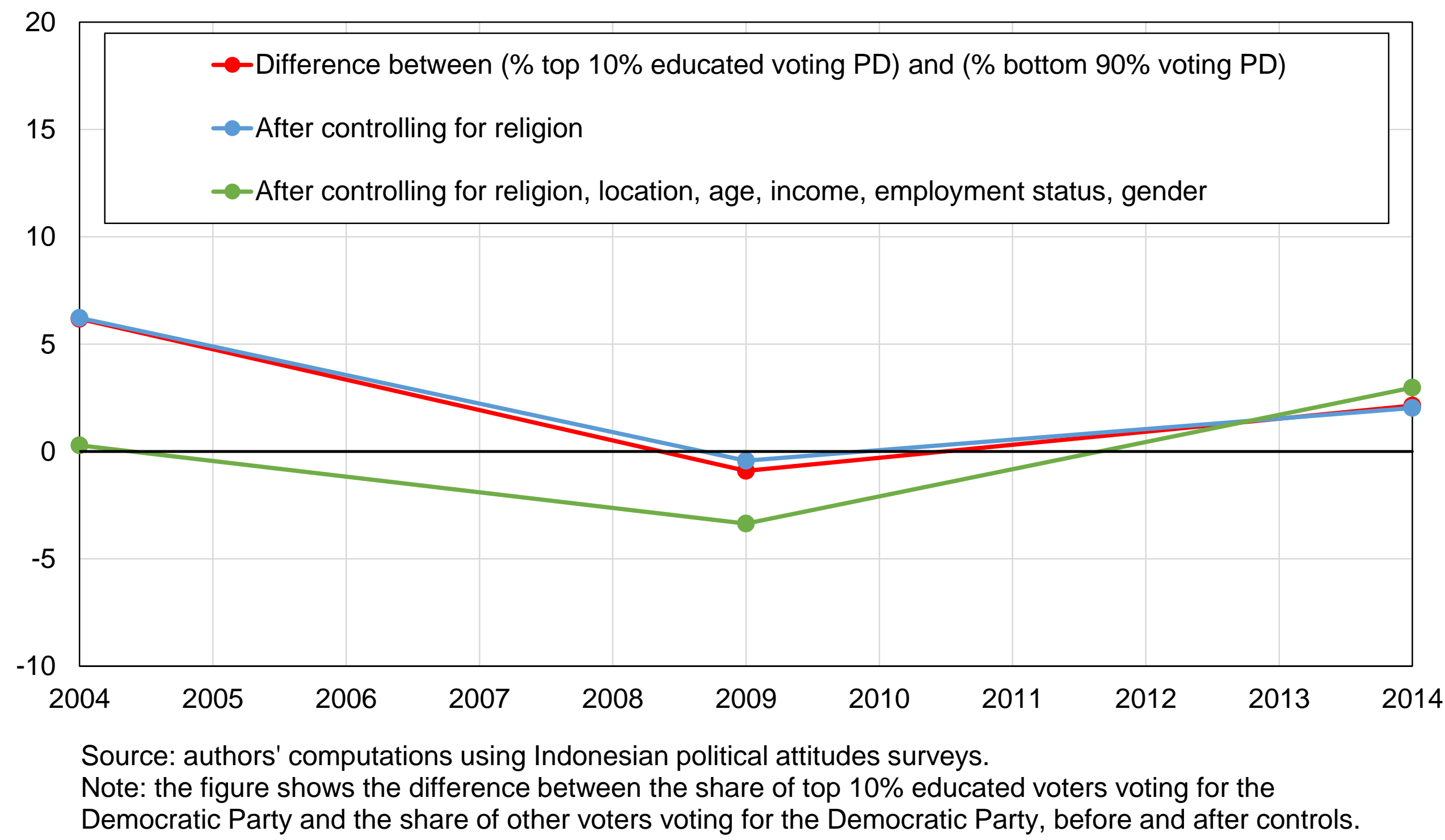


Figure DE3 - Vote for PD by income group

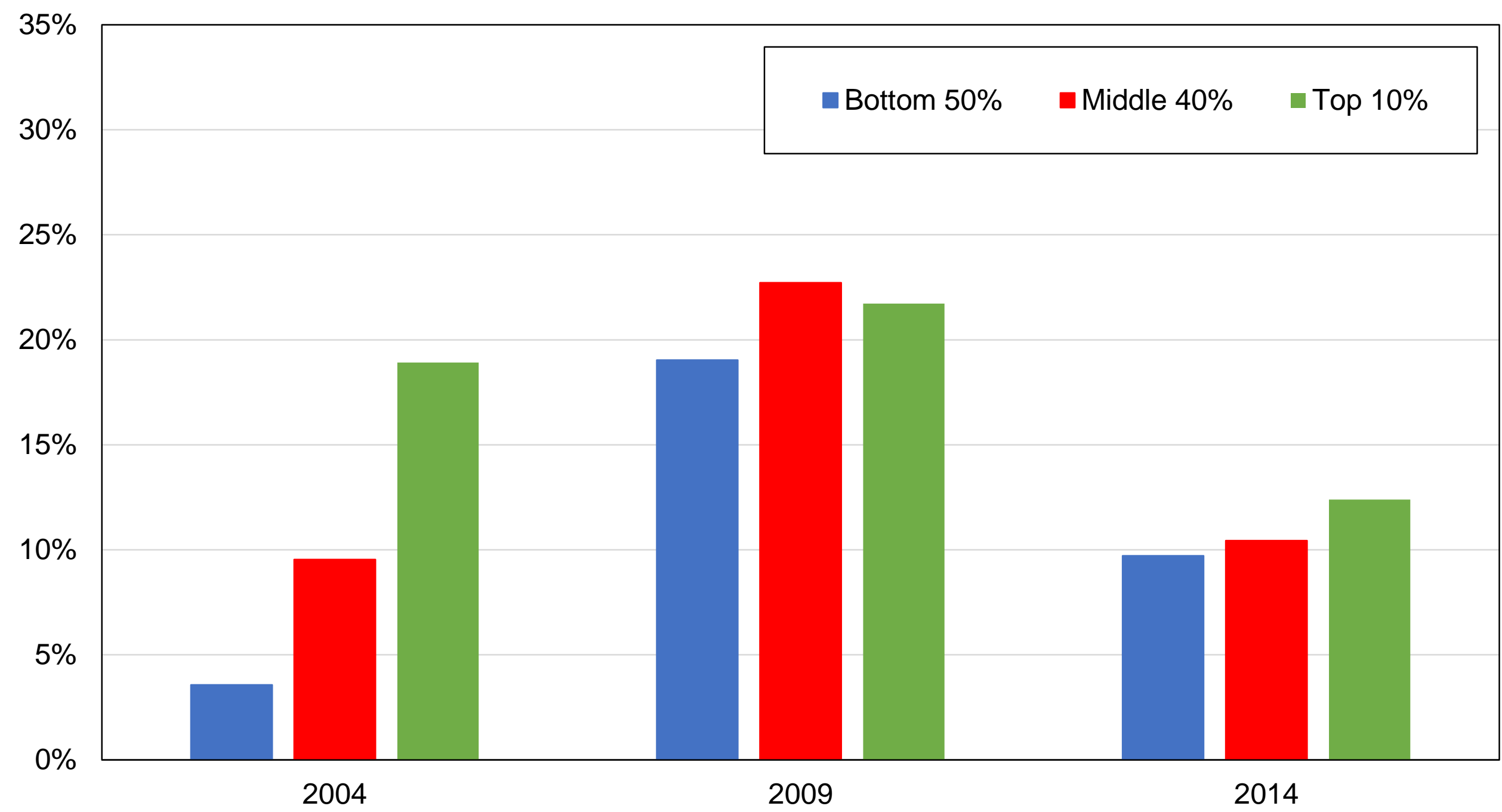

Source: authors' computations using Indonesian political attitudes surveys.

Note: the figure shows the share of votes received by PD by income group. 


\section{Figure DE4 - Vote for PD among top-income voters}

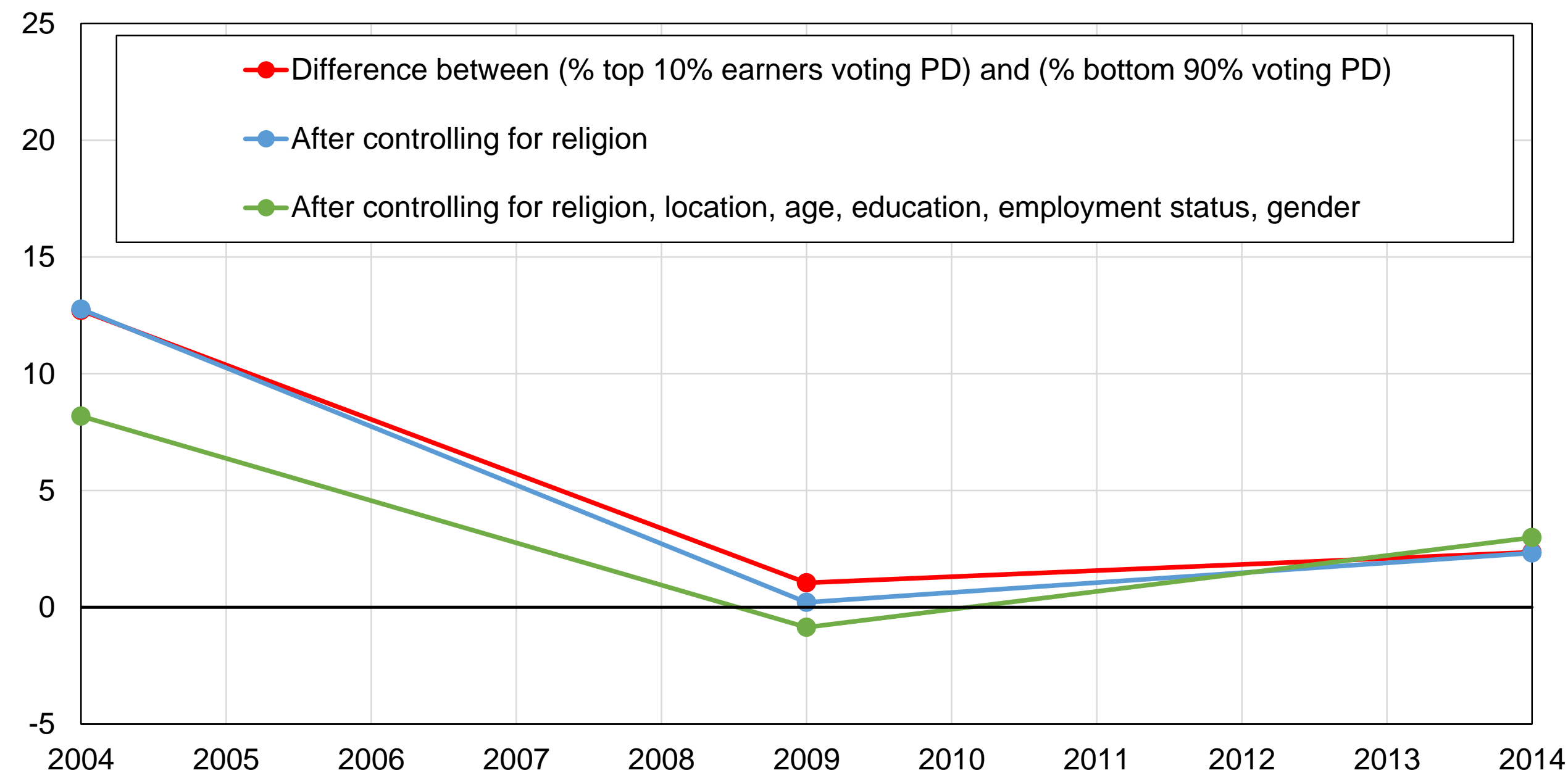

Source: authors' computations using Indonesian political attitudes surveys.

Note: the figure shows the difference between the share of top $10 \%$ earners voting for the Democratic Party and the share of other voters voting for the Democratic Party, before and after controls. 
Figure DE5 - Vote for PD by religion

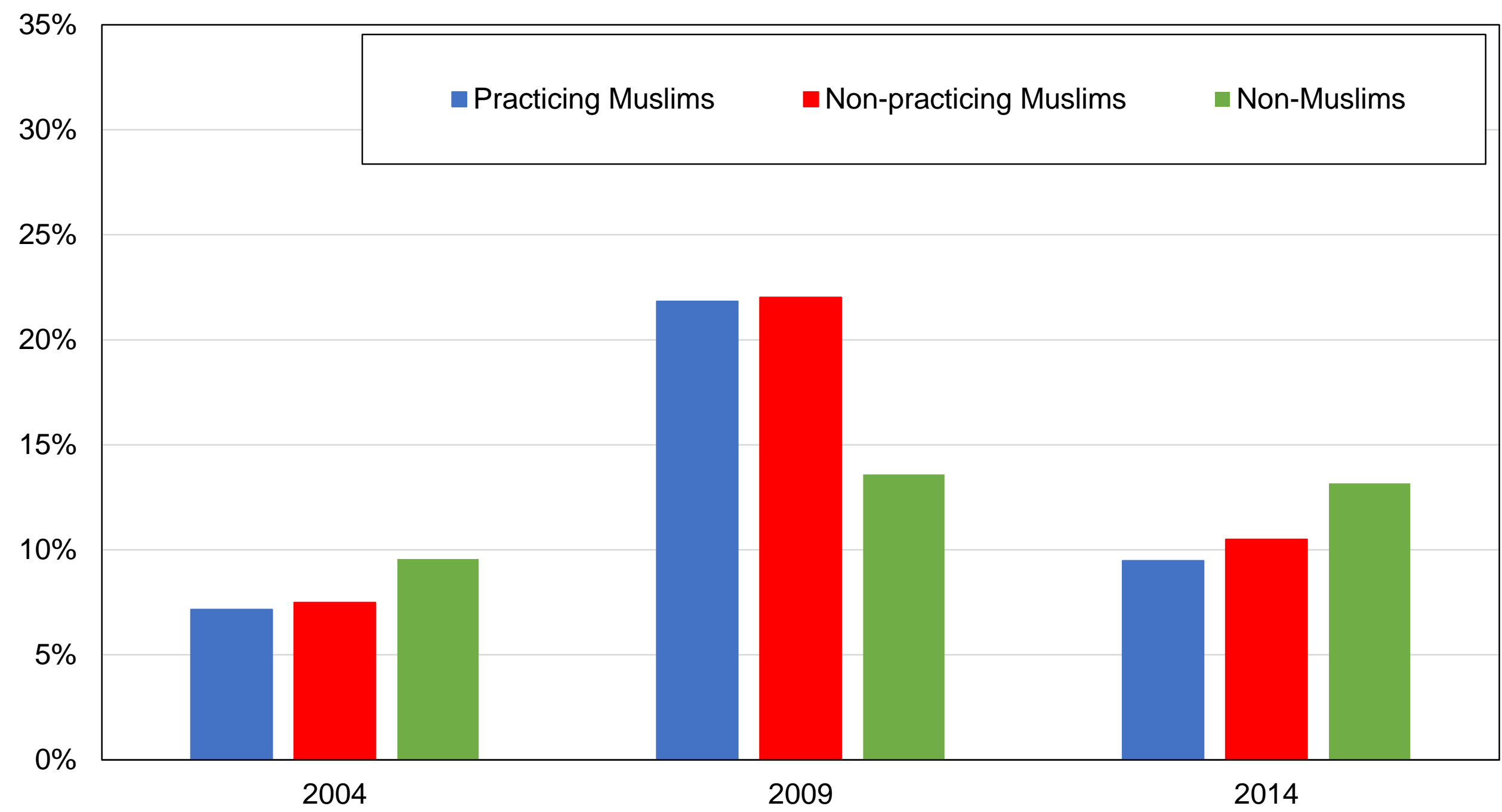

Source: authors' computations using Indonesian political attitudes surveys.

Note: the figure shows the share of votes received by PD by religion. 


\section{Figure DE6 - Vote for PD among practicing Muslims}

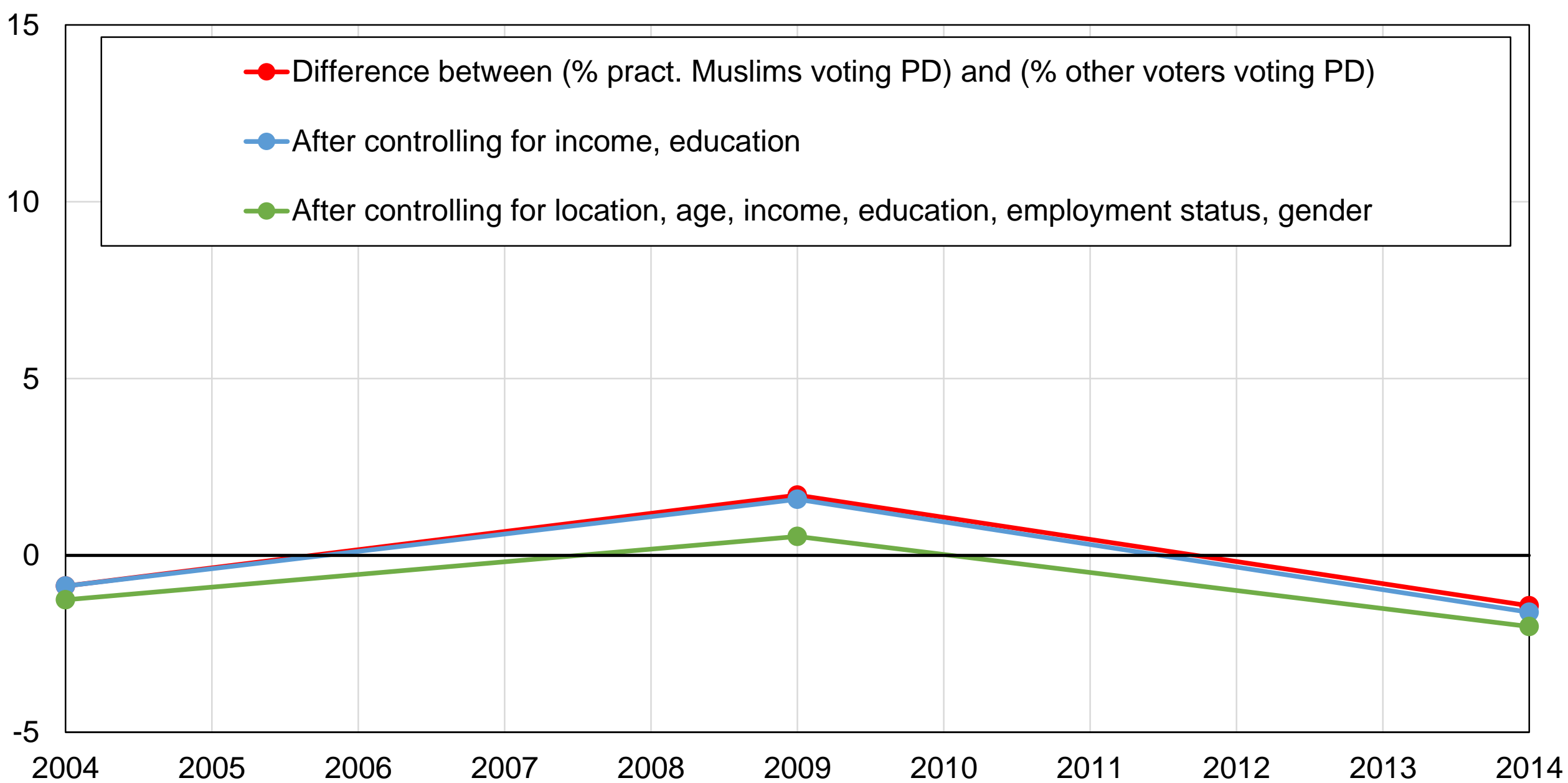

Source: authors' computations using Indonesian political attitudes surveys.

Note: the figure shows the difference between the share of practicing Muslims voting for the Democratic

Party and the share of other voters voting for the Democratic Party, before and after controls. 
Figure DE7 - Vote for PD by age group

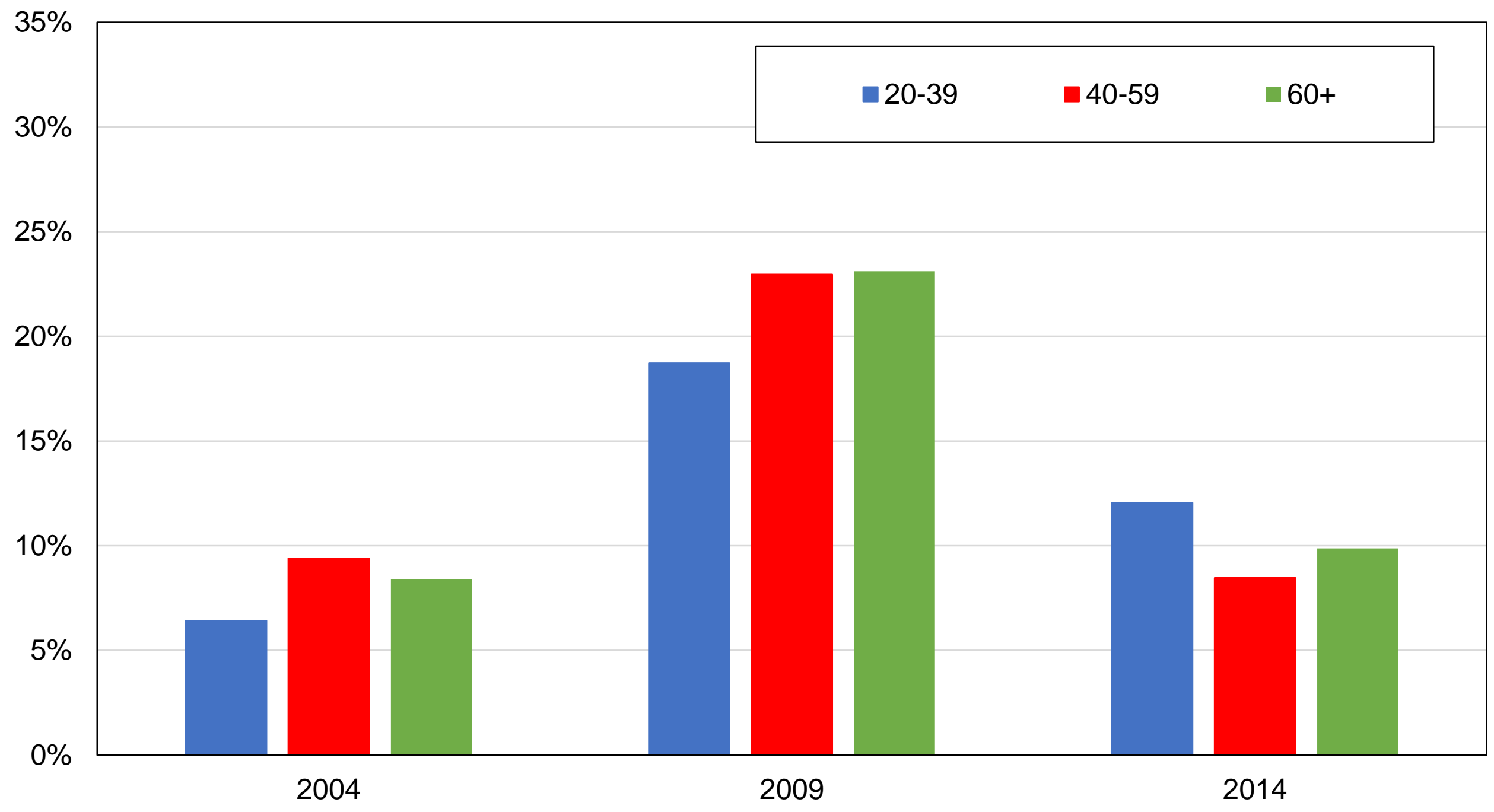

Source: authors' computations using Indonesian political attitudes surveys.

Note: the figure shows the share of votes received by PD by age group. 


\section{Figure DE8 - Vote for PD among young voters}

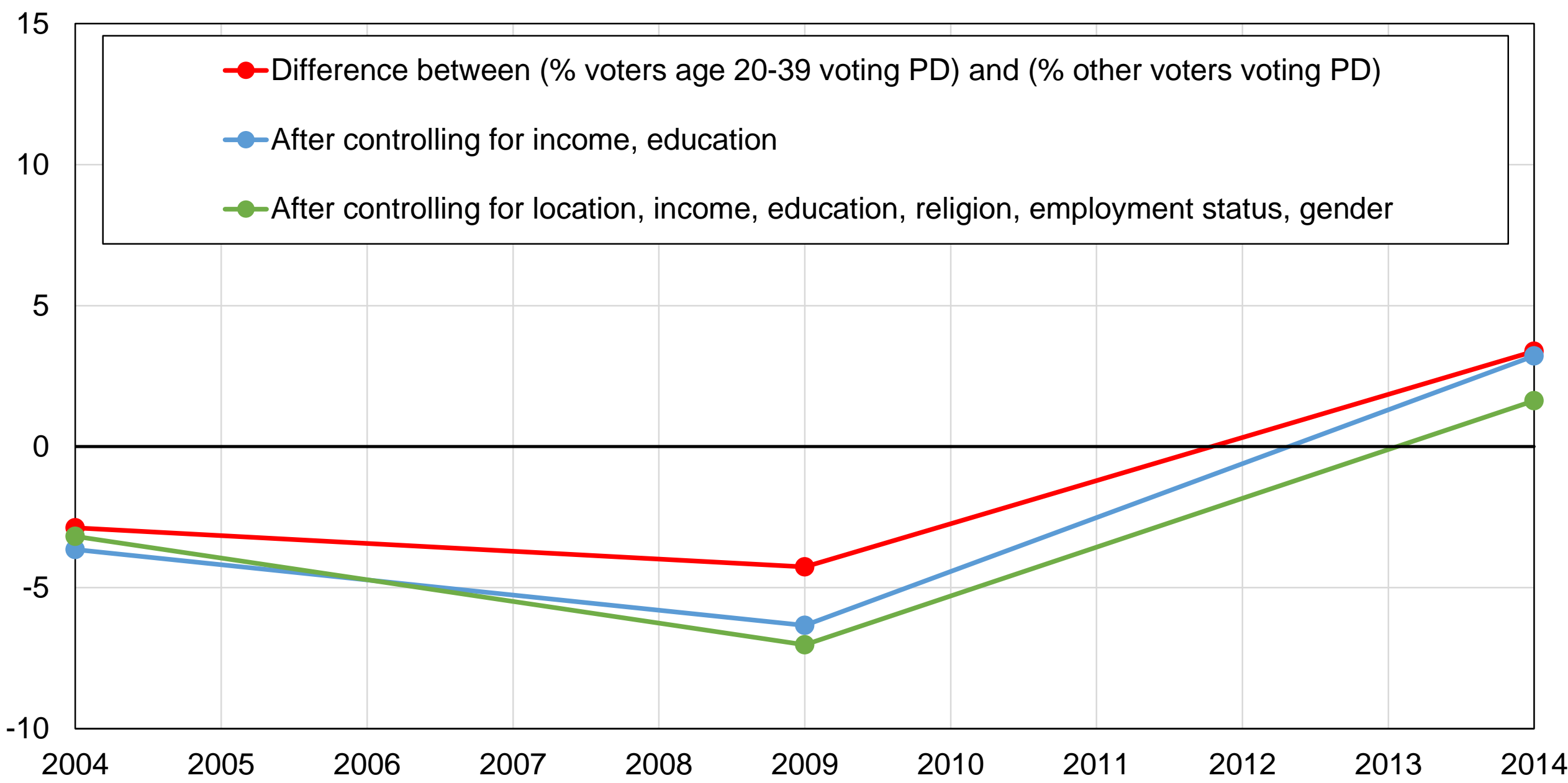

Source: authors' computations using Indonesian political attitudes surveys.

Note: the figure shows the difference between share of young voters voting for the Democratic Party and the share of other voters voting for the Democratic Party, before and after controls. 
Figure DE9 - Vote for PD by rural-urban location

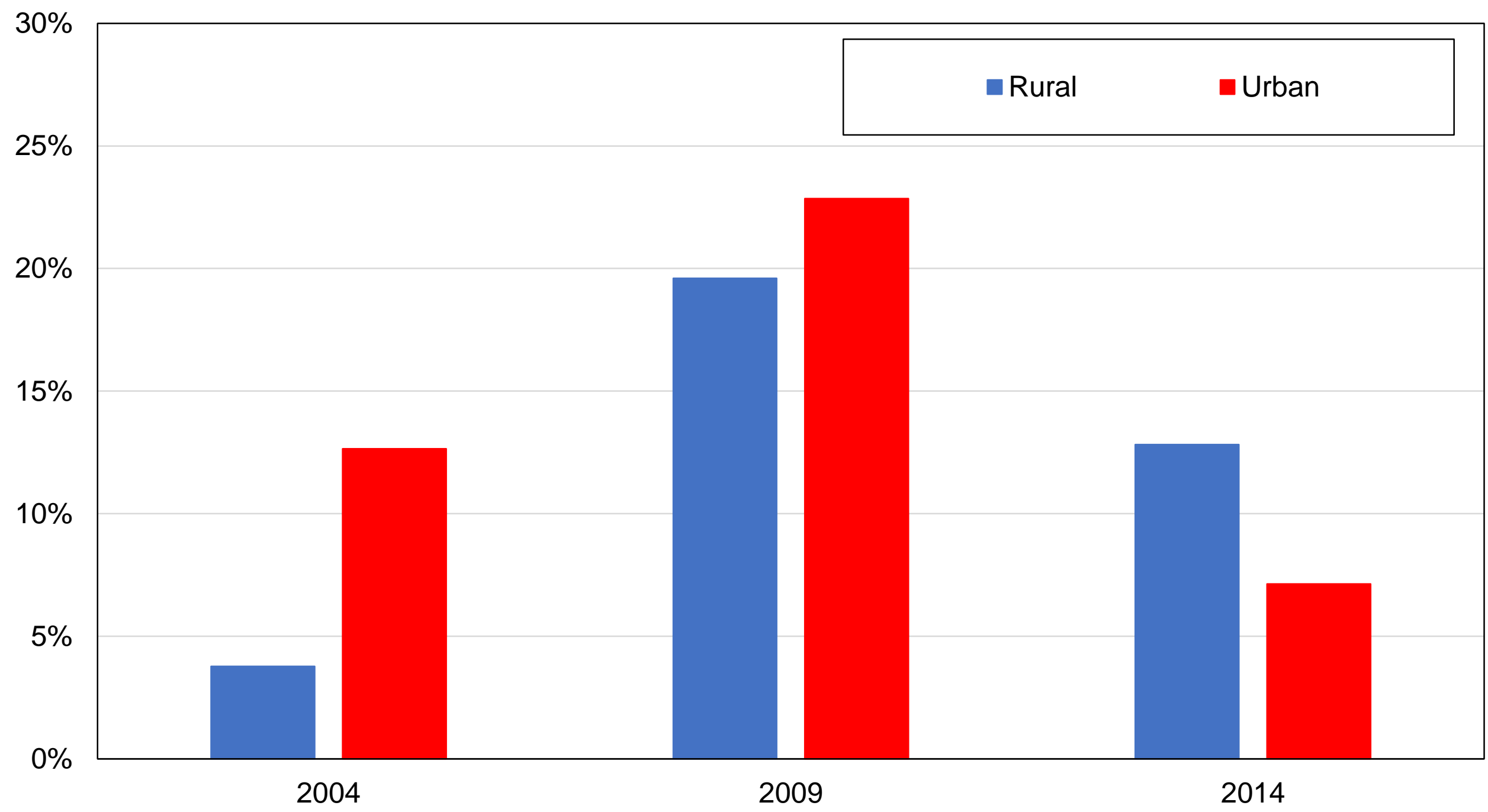

Source: authors' computations using Indonesian political attitudes surveys.

Note: the figure shows the share of votes received by PD by rural-urban location. 


\section{Figure DE10 - Vote for PD among urban voters}

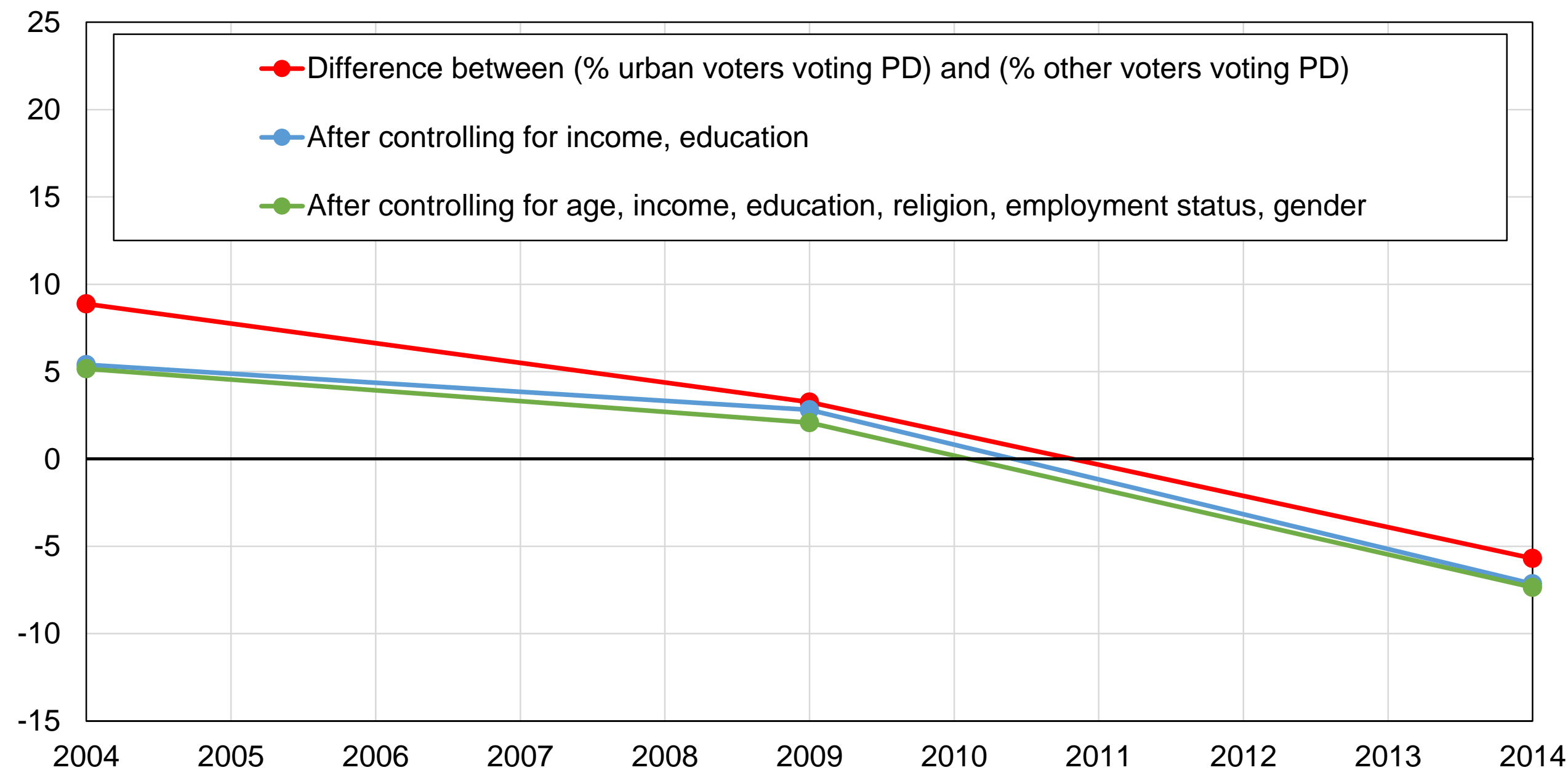

Source: authors' computations using Indonesian political attitudes surveys.

Note: the figure shows the difference between the share of urban voters voting for PD and the share of other voters voting for PD, before and after controls. 
Figure DE11 - Vote for PD by ethnicity

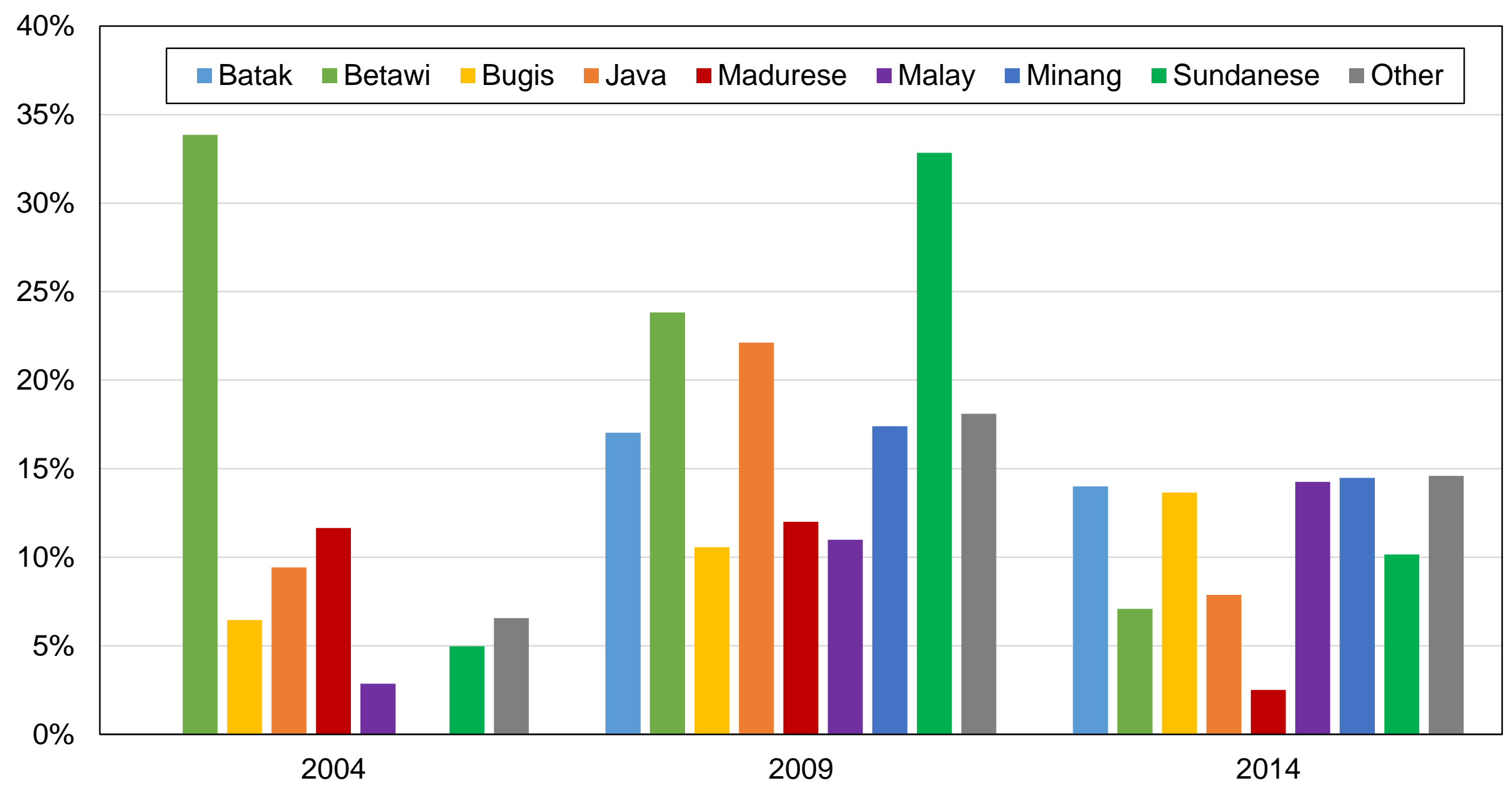

Source: authors' computations using Indonesian political attitudes surveys.

Note: the figure shows the share of votes received by PD by ethnic affiliation. 


\section{Figure DE12 - Vote for PD among Javanese voters}

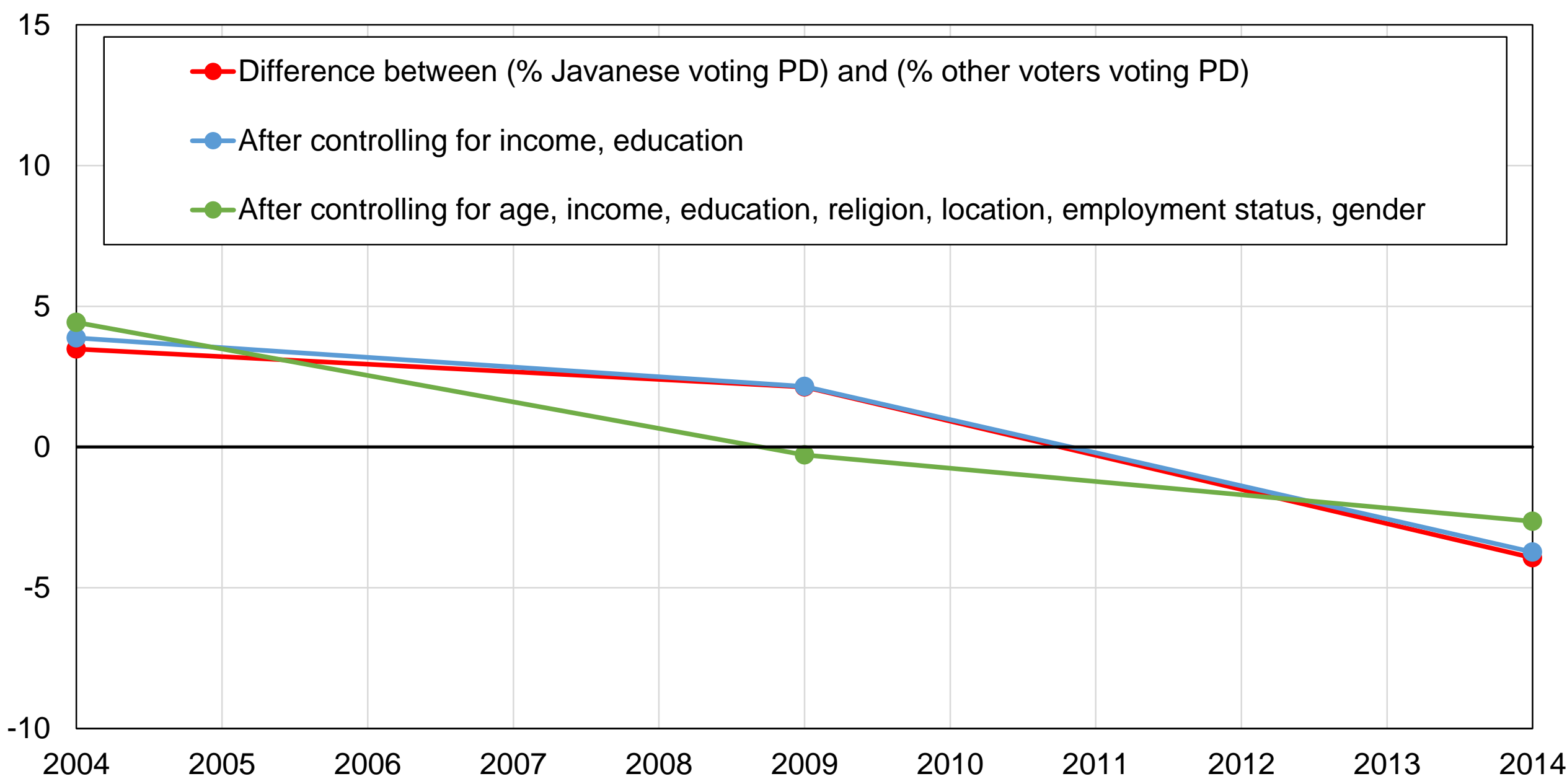

Source: authors' computations using Indonesian political attitudes surveys.

Note: the figure shows the difference between the share of Javanese voters voting for PD and the share of other voters voting for PD, before and after controls. 


\section{Figure DF1 - Vote for Gerindra by education level}

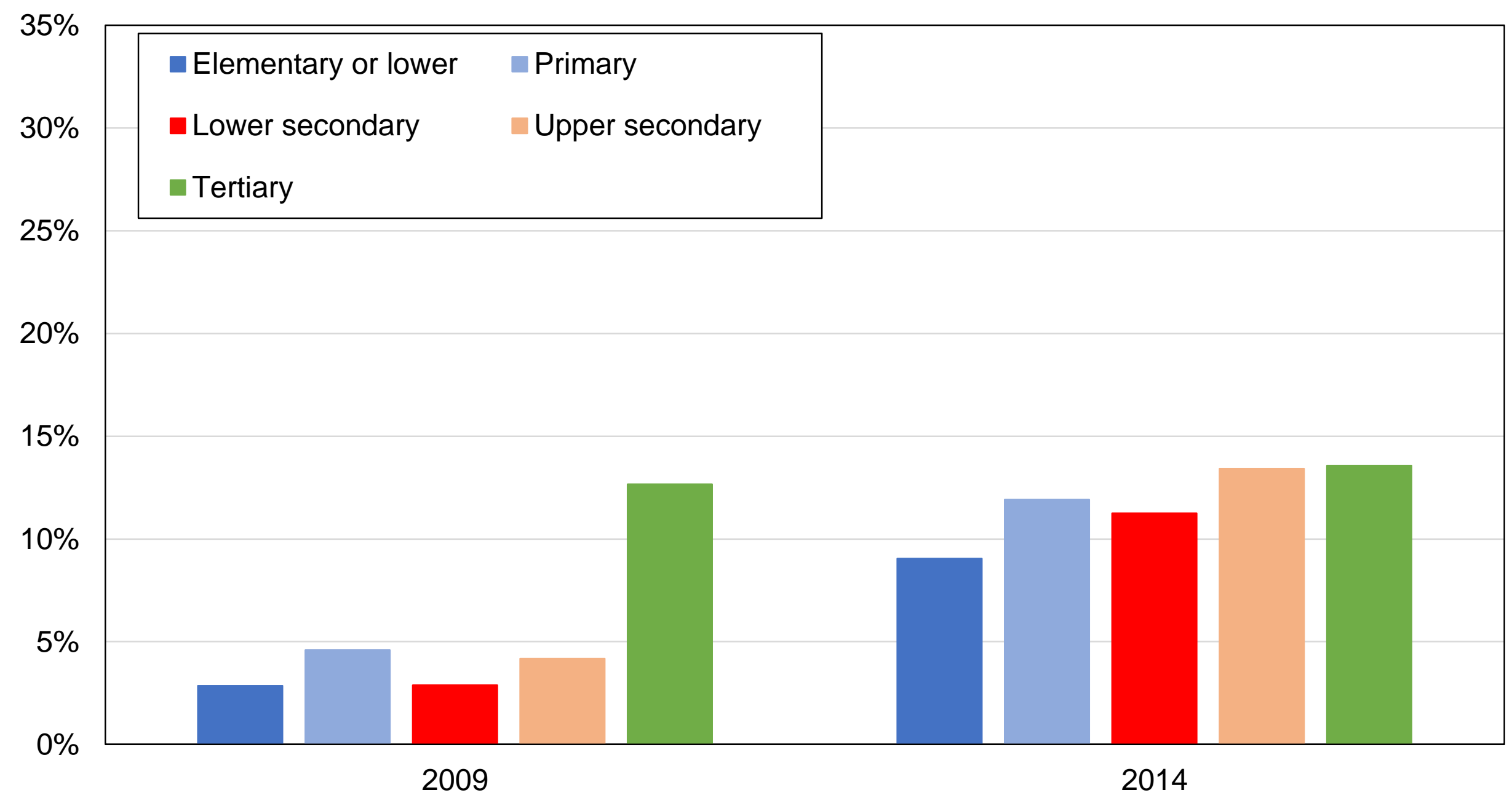

Source: authors' computations using Indonesian political attitudes surveys.

Note: the figure shows the share of votes received by Gerindra by education level. 


\section{Figure DG2 - Vote for Gerindra among higher-educated voters}

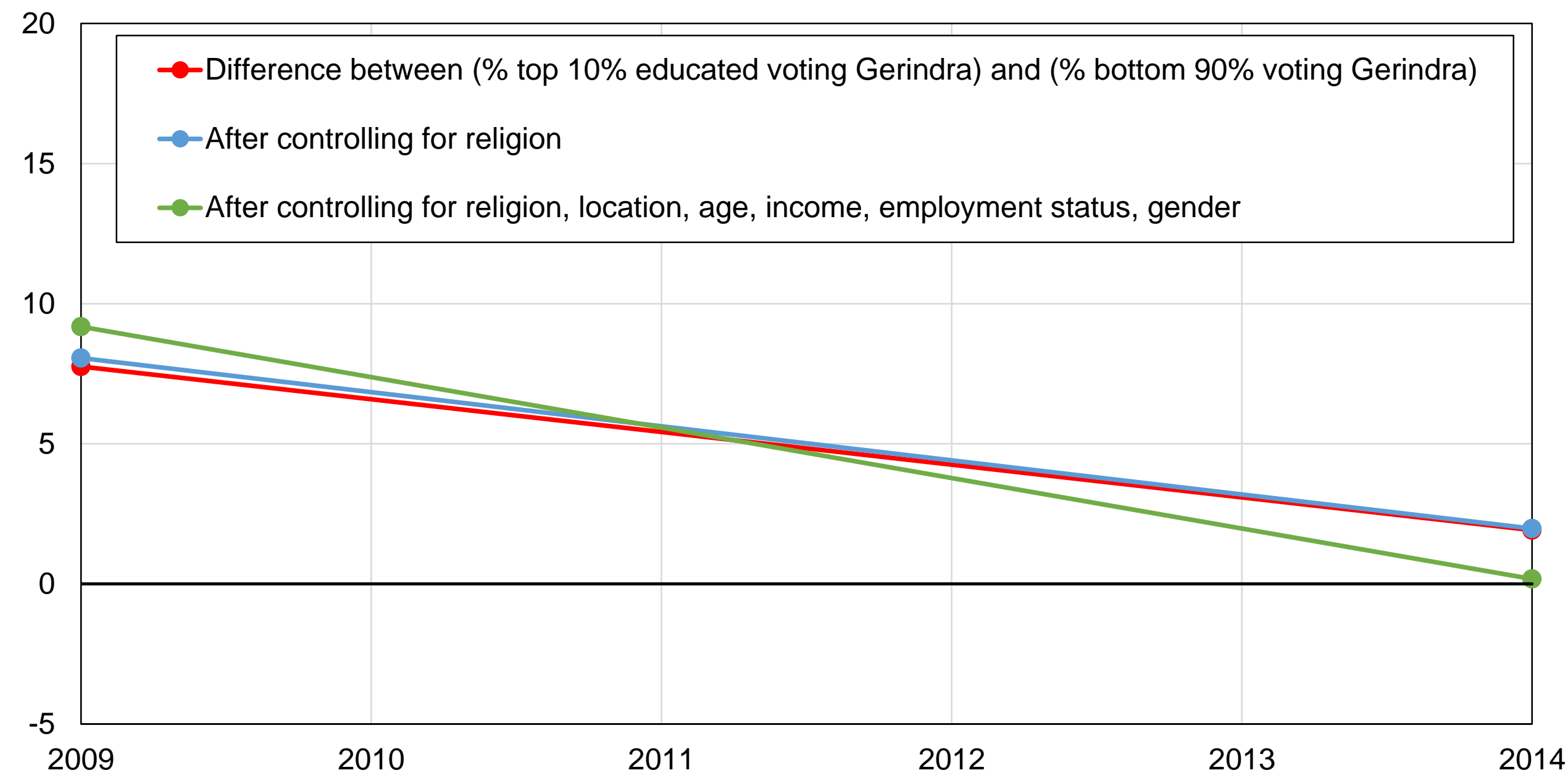

Source: authors' computations using Indonesian political attitudes surveys.

Note: the figure shows the difference between the share of top $10 \%$ educated voters voting for Gerindra and the share of other voters voting for Gerindra, before and after controls. 
Figure DF3 - Vote for Gerindra by income group

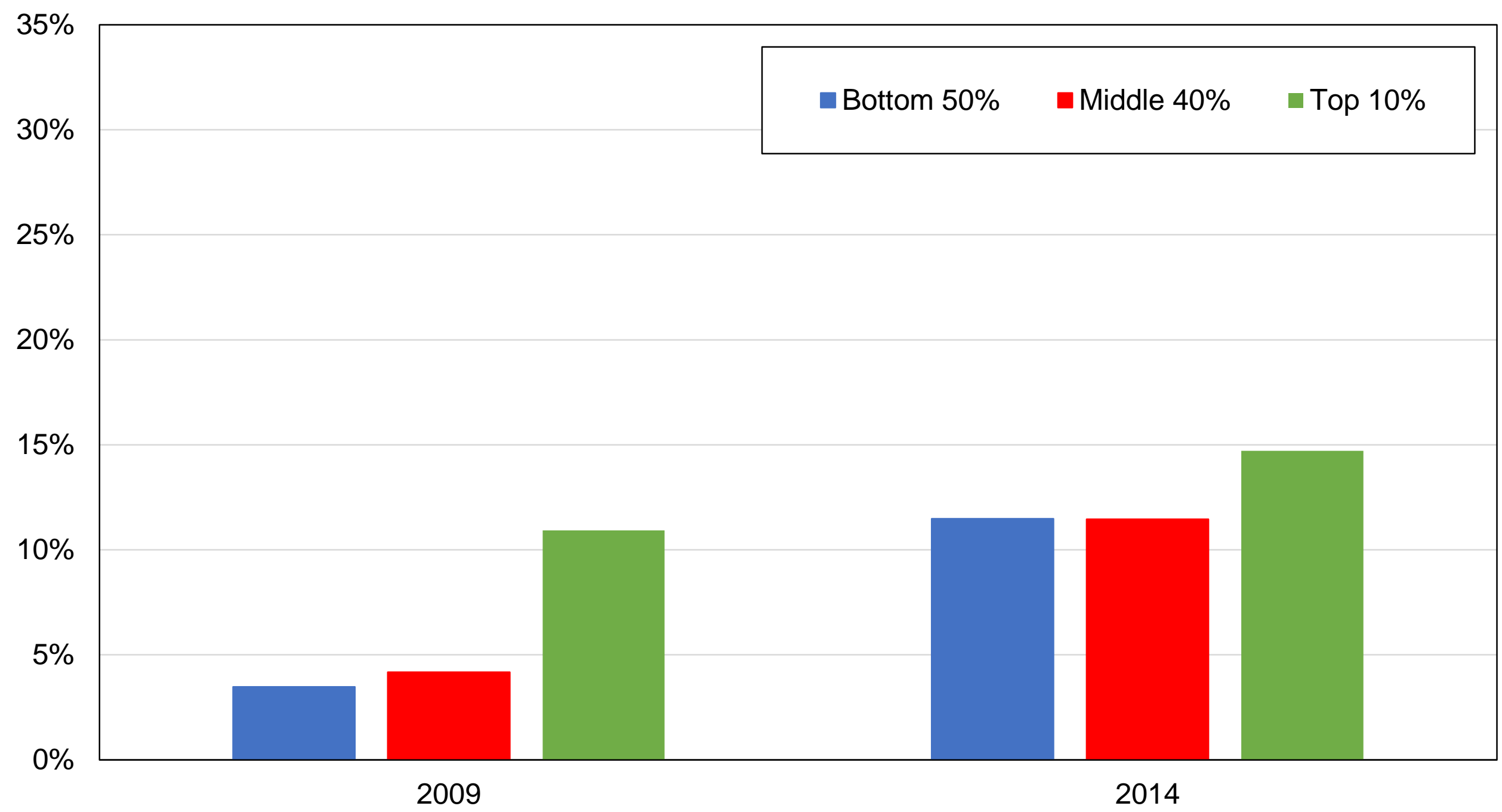

Source: authors' computations using Indonesian political attitudes surveys.

Note: the figure shows the share of votes received by Gerindra by income group. 


\section{Figure DF4 - Vote for Gerindra among top-income voters}

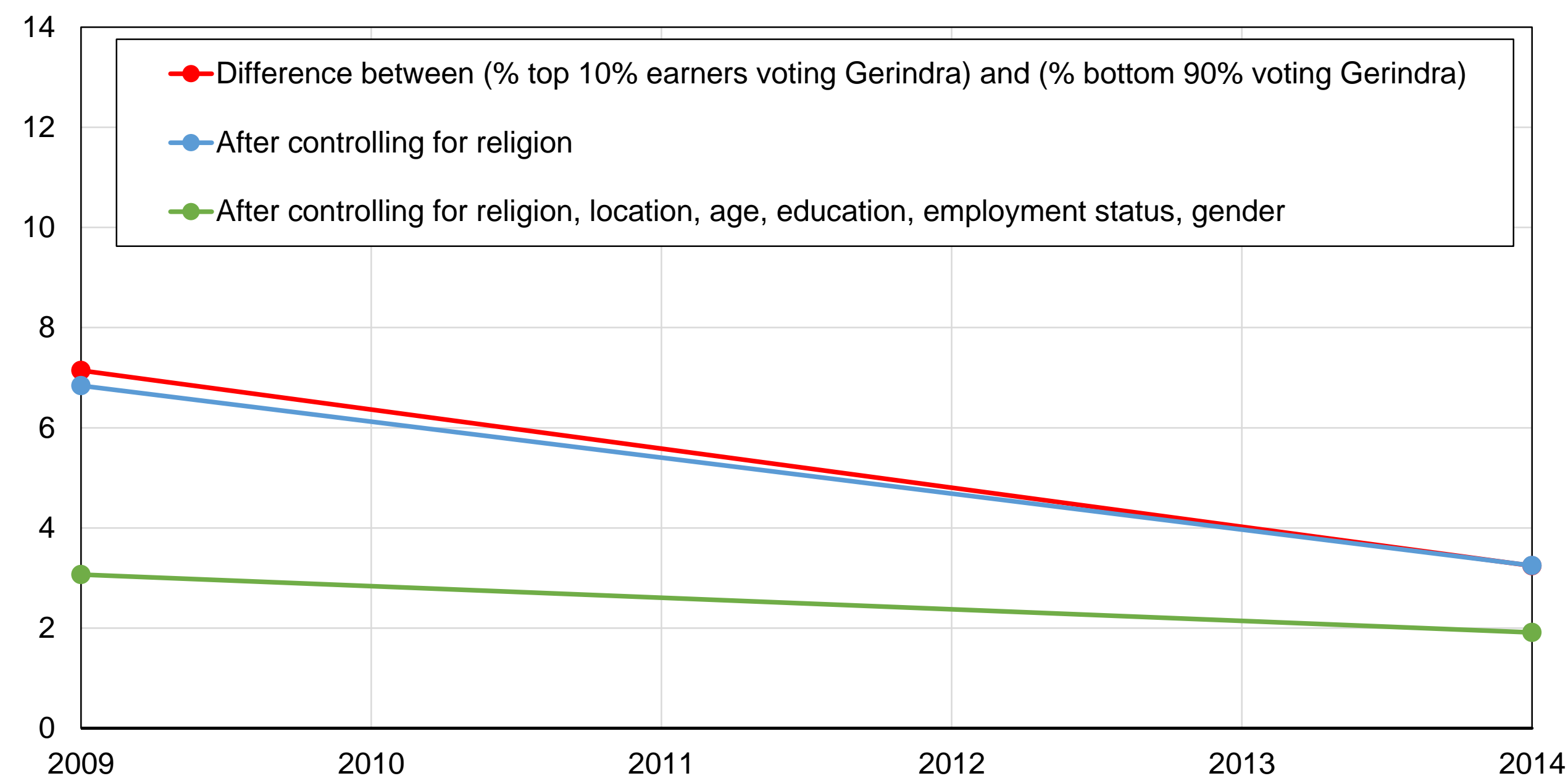

Source: authors' computations using Indonesian political attitudes surveys.

Note: the figure shows the difference between the share of top $10 \%$ earners voting for Gerindra and the share of other voters voting for Gerindra, before and after controls. 
Figure DF5 - Vote for Gerindra by religion

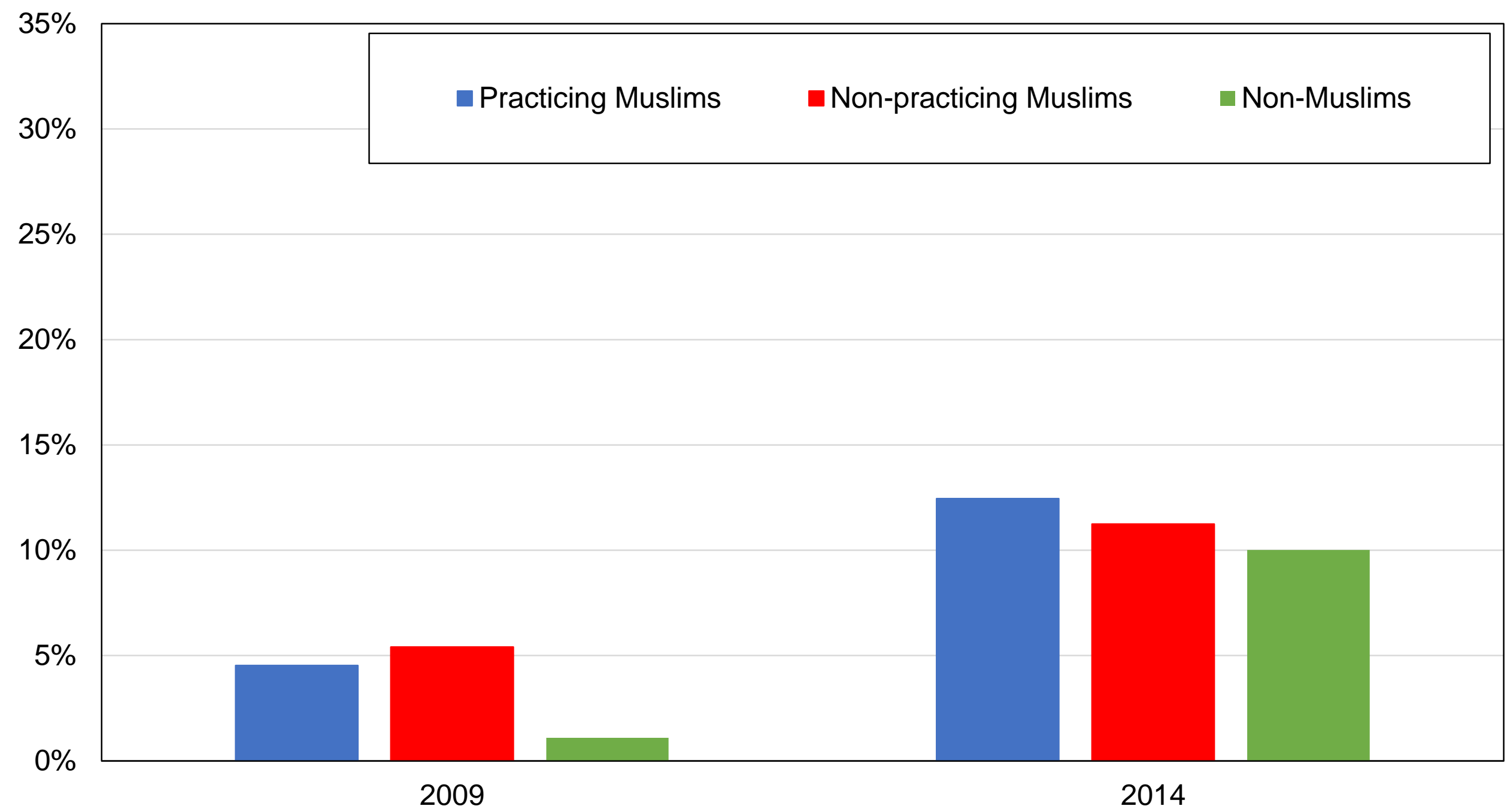

Source: authors' computations using Indonesian political attitudes surveys. Note: the figure shows the share of votes received by Gerindra by religion. 


\section{Figure DF6 - Vote for Gerindra among practicing Muslims}

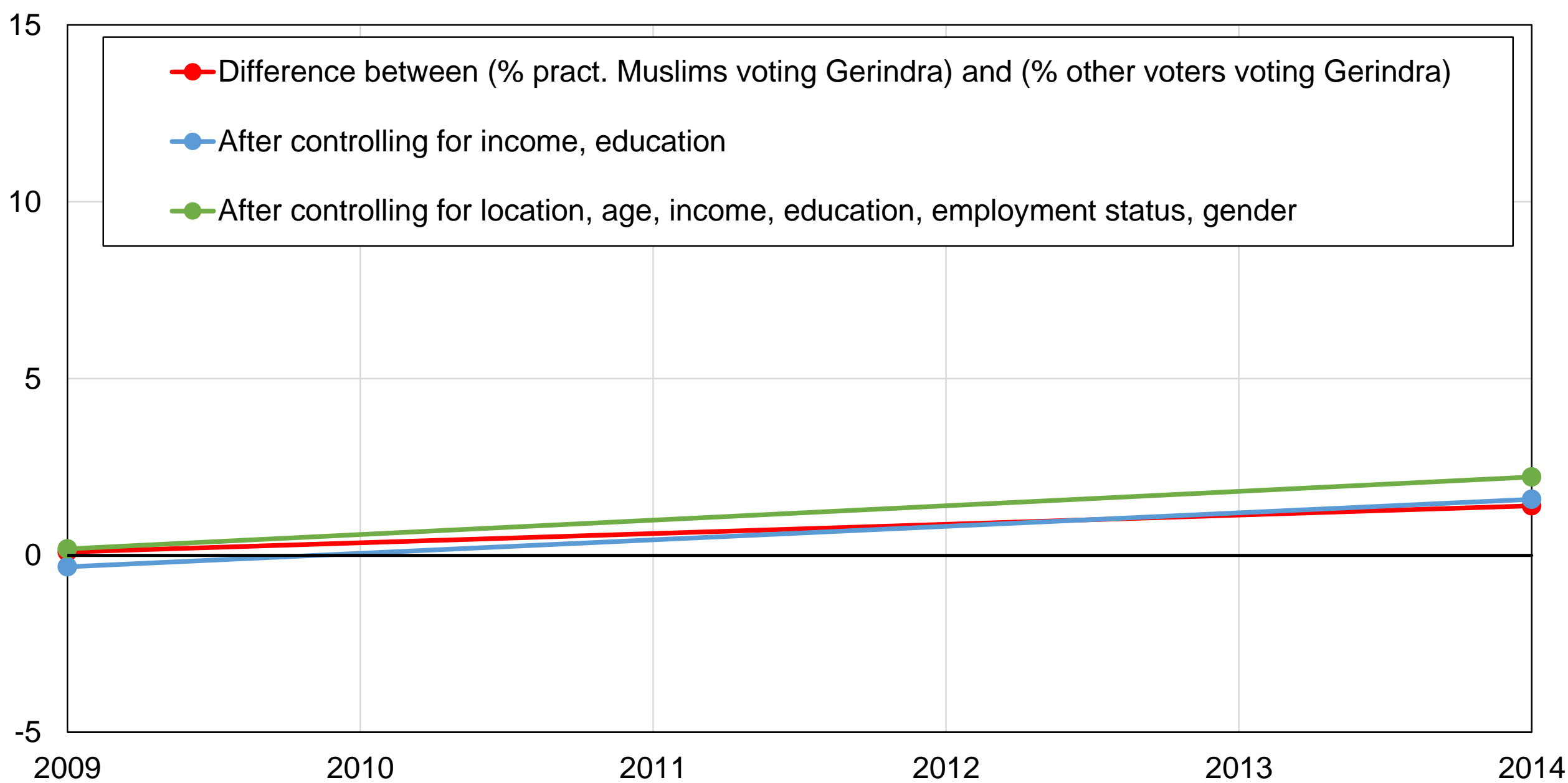

Source: authors' computations using Indonesian political attitudes surveys.

Note: the figure shows the difference between the share of practicing Muslims voting for Gerindra and the share of other voters voting for Gerindra, before and after controls. 
Figure DF7 - Vote for Gerindra by age group

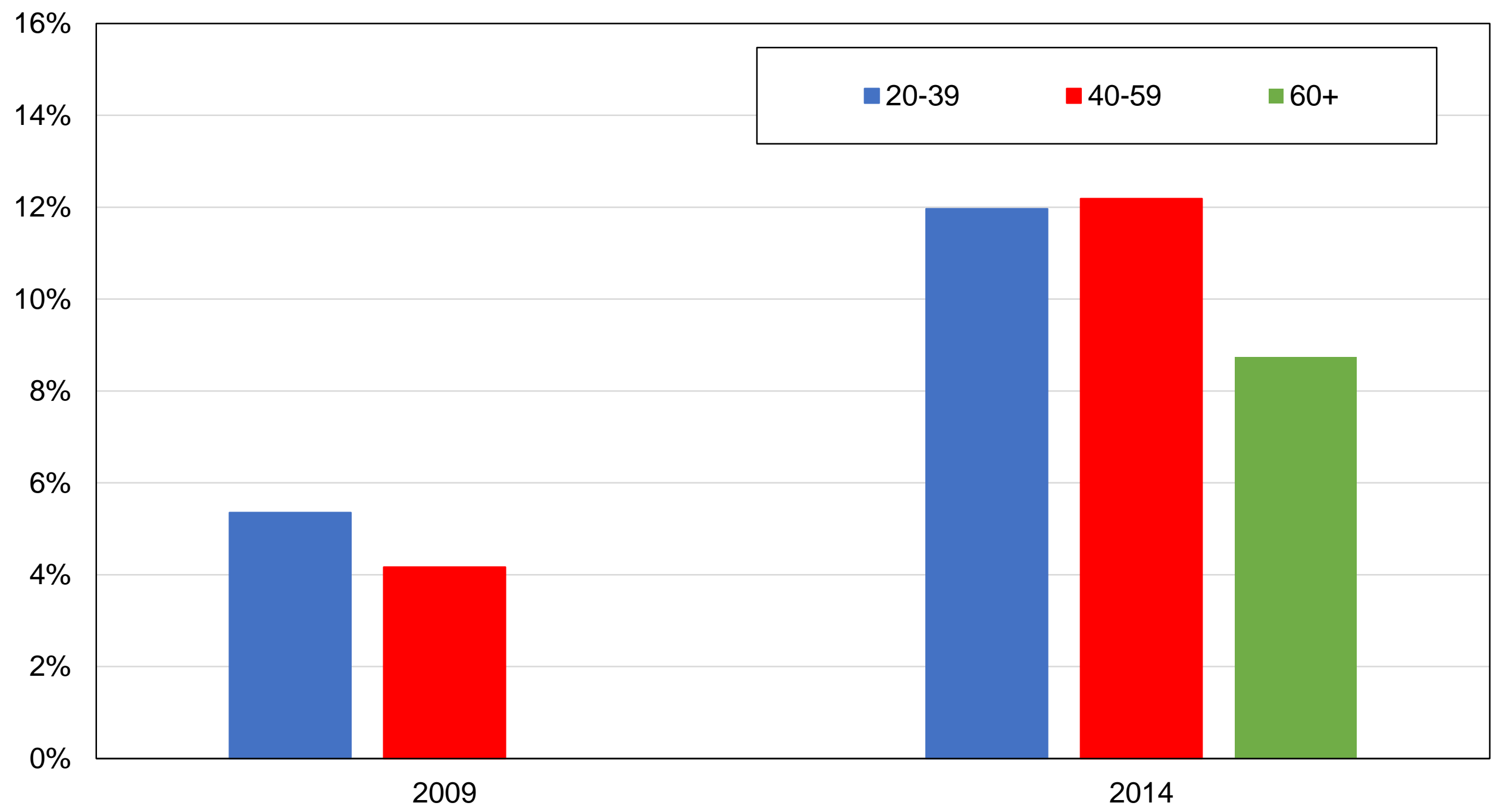

Source: authors' computations using Indonesian political attitudes surveys.

Note: the figure shows the share of votes received by Gerindra by age group. 


\section{Figure DF8 - Vote for Gerindra among young voters}

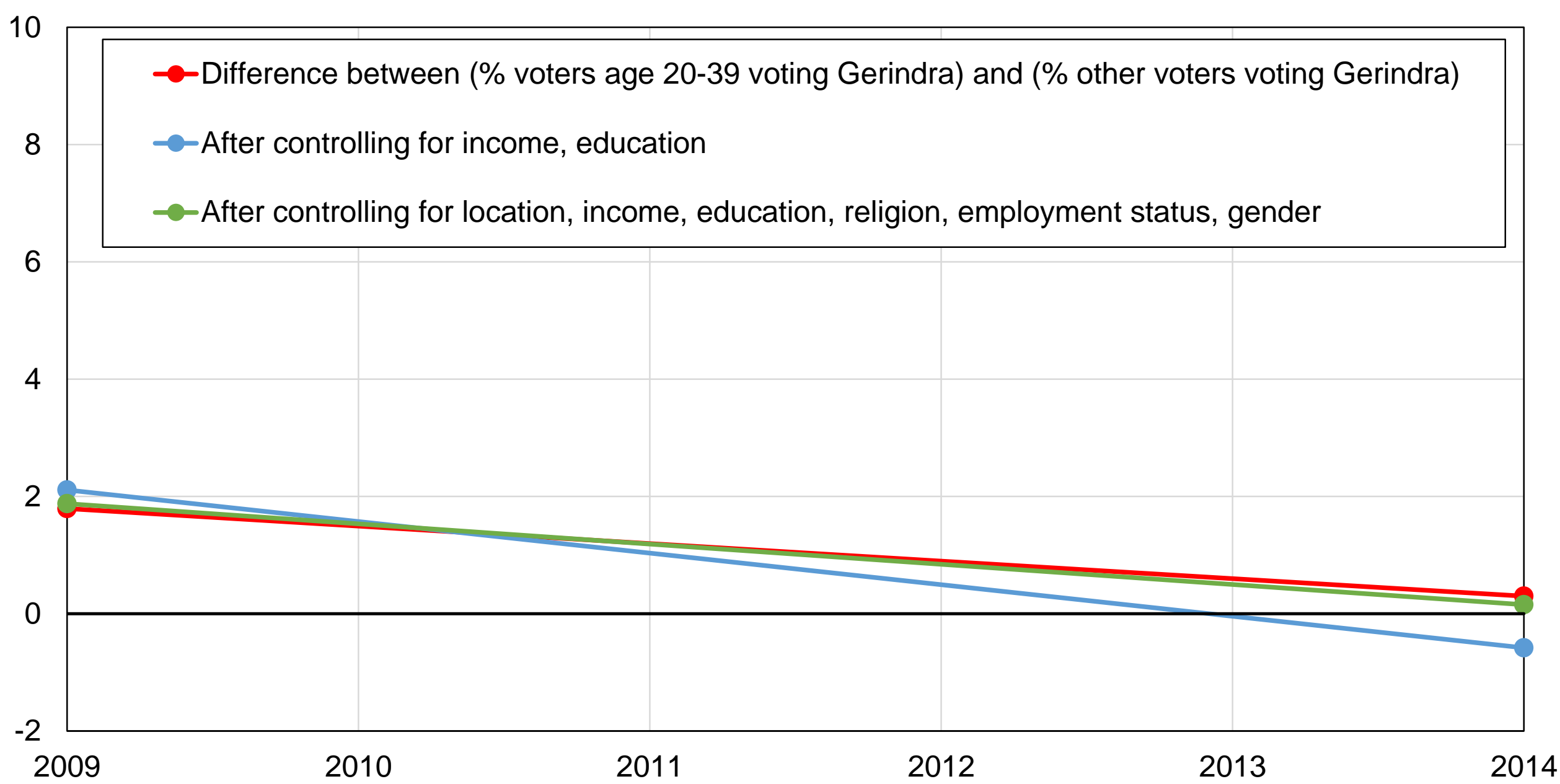

Source: authors' computations using Indonesian political attitudes surveys.

Note: the figure shows the difference between share of young voters voting for Gerindra and the share of other voters voting for Gerindra, before and after controls. 
Figure DF9 - Vote for Gerindra by rural-urban location

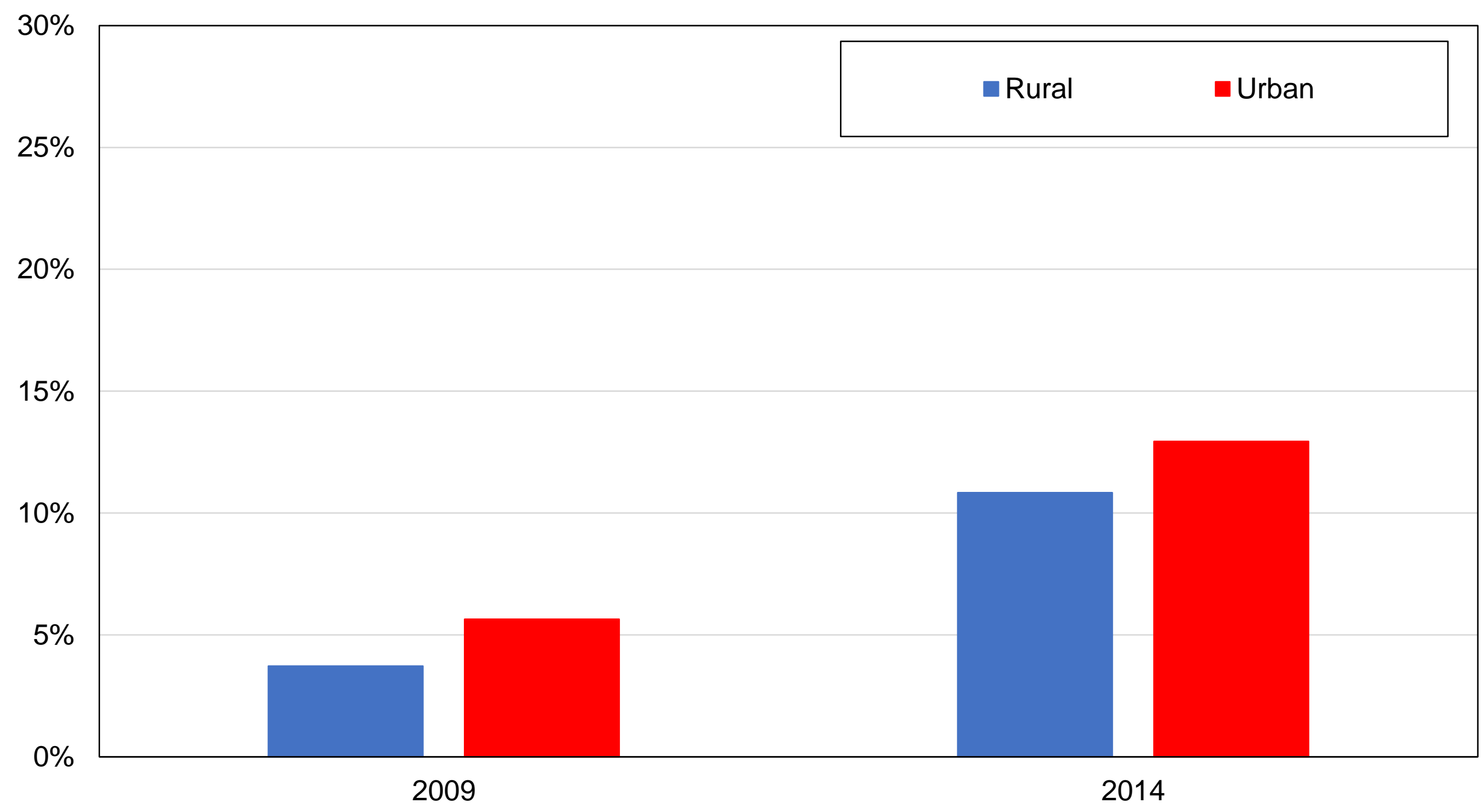

Source: authors' computations using Indonesian political attitudes surveys.

Note: the figure shows the share of votes received by Gerindra by rural-urban location. 


\section{Figure DF10 - Vote for Gerindra among urban voters}

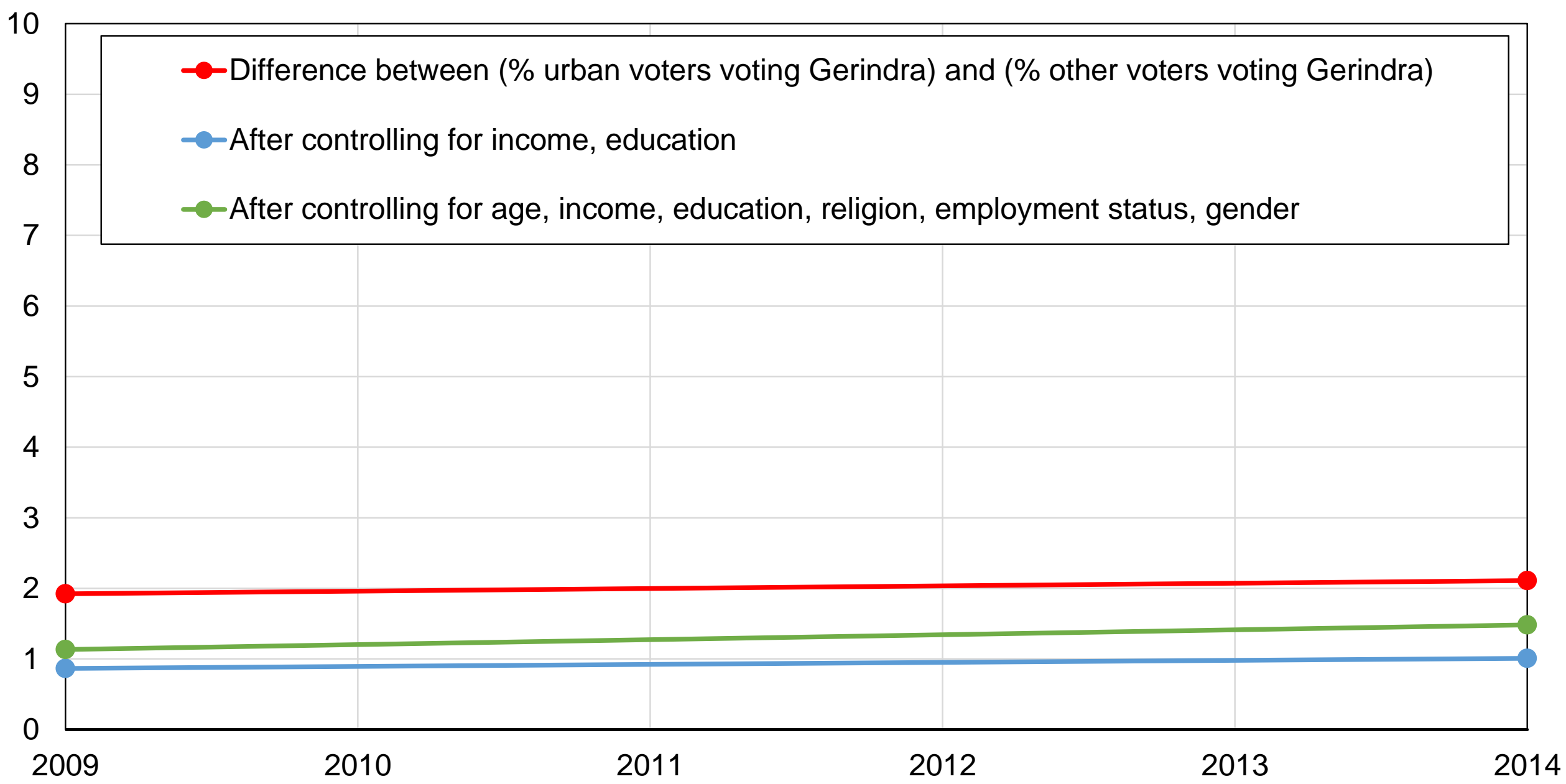

Source: authors' computations using Indonesian political attitudes surveys.

Note: the figure shows the difference between the share of urban voters voting for Gerindra and the share of other voters voting for Gerindra, before and after controls. 


\section{Figure DG1 - Vote for Hanura by education level}

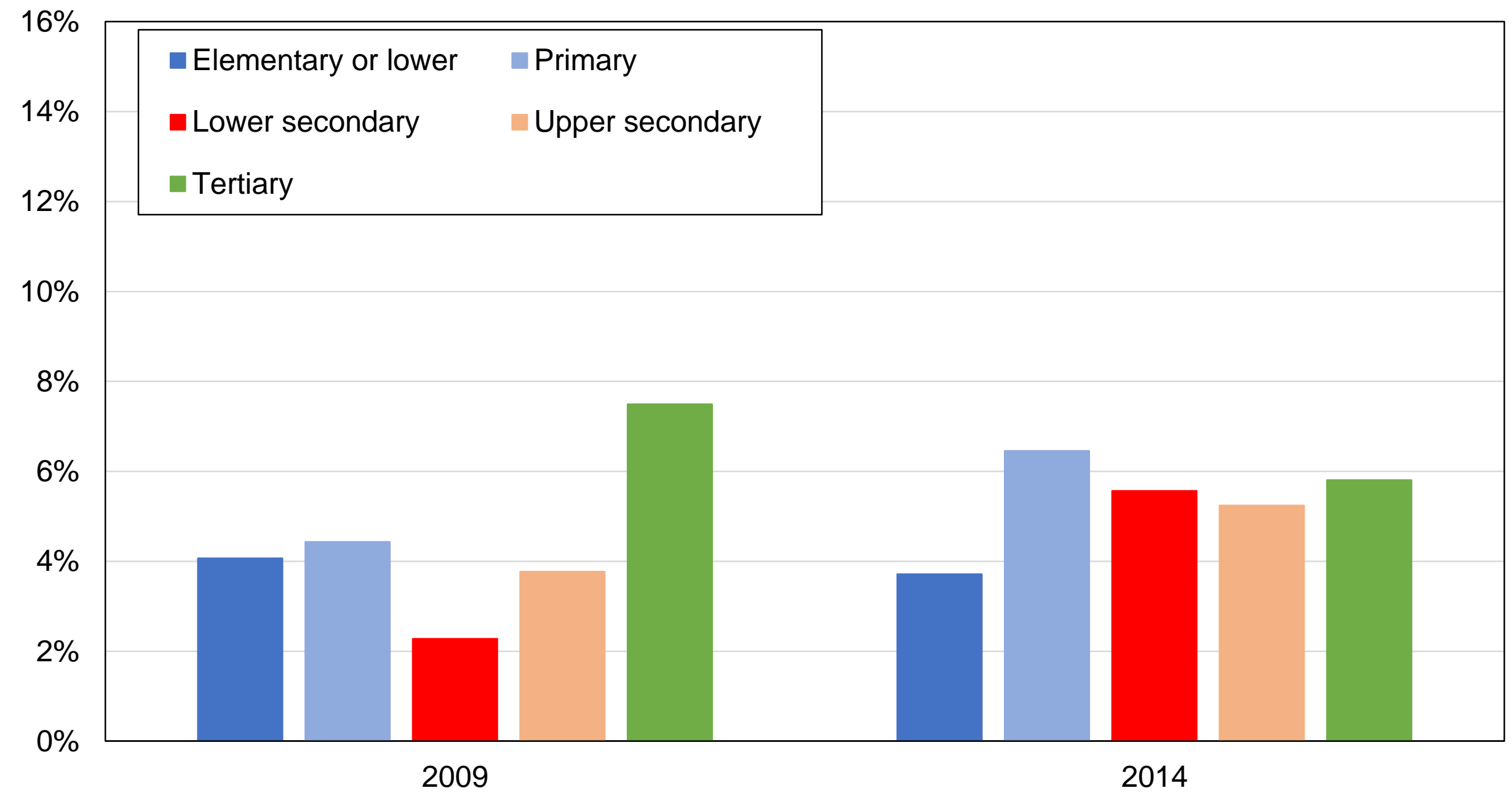

Source: authors' computations using Indonesian political attitudes surveys.

Note: the figure shows the share of votes received by Hanura by education level. 


\section{Figure DG2 - Vote for Hanura among higher-educated voters}

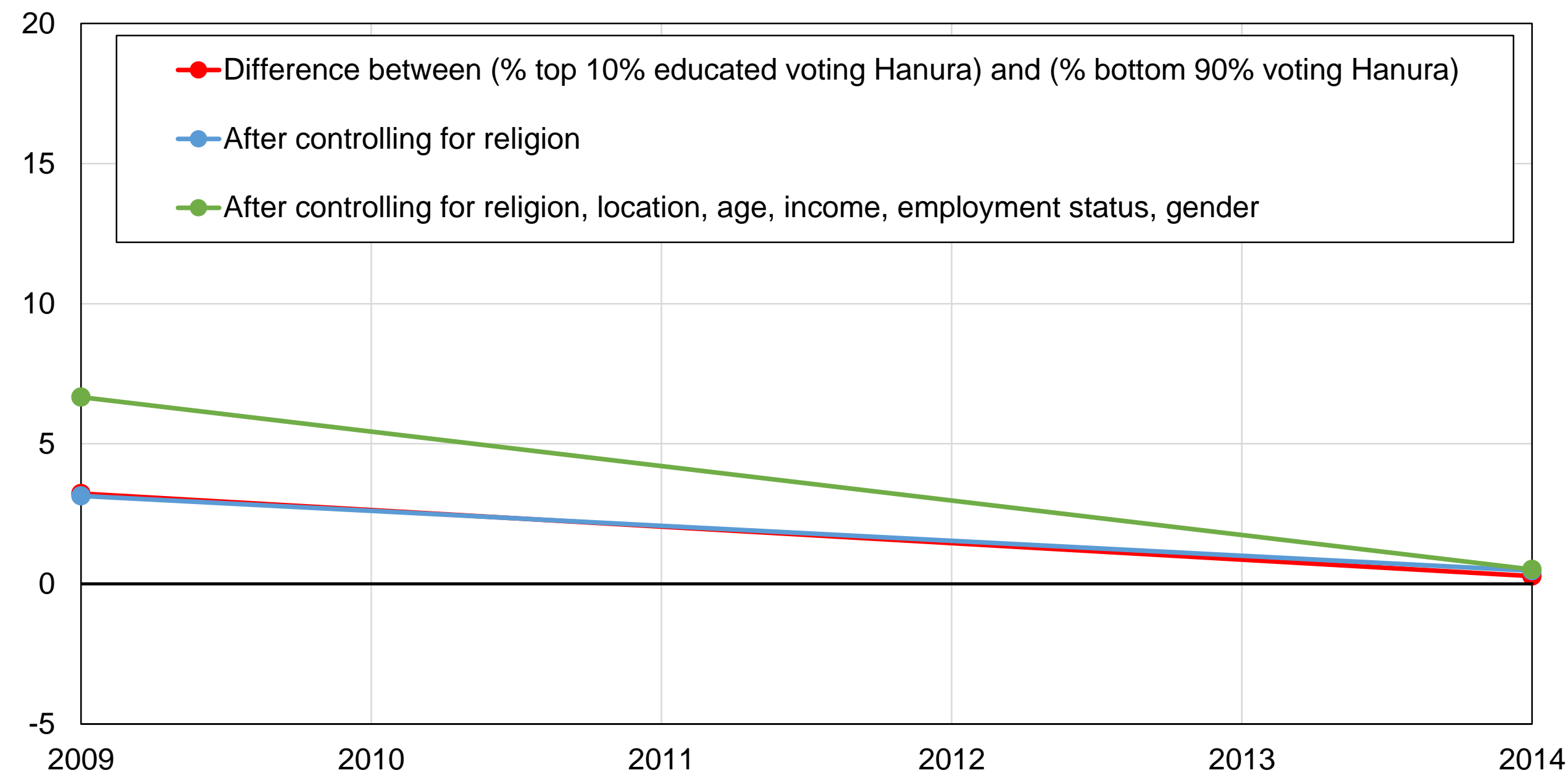

Source: authors' computations using Indonesian political attitudes surveys.

Note: the figure shows the difference between the share of top $10 \%$ educated voters voting for Hanura and the share of other voters voting for Hanura, before and after controls. 
Figure DG3 - Vote for Hanura by income group

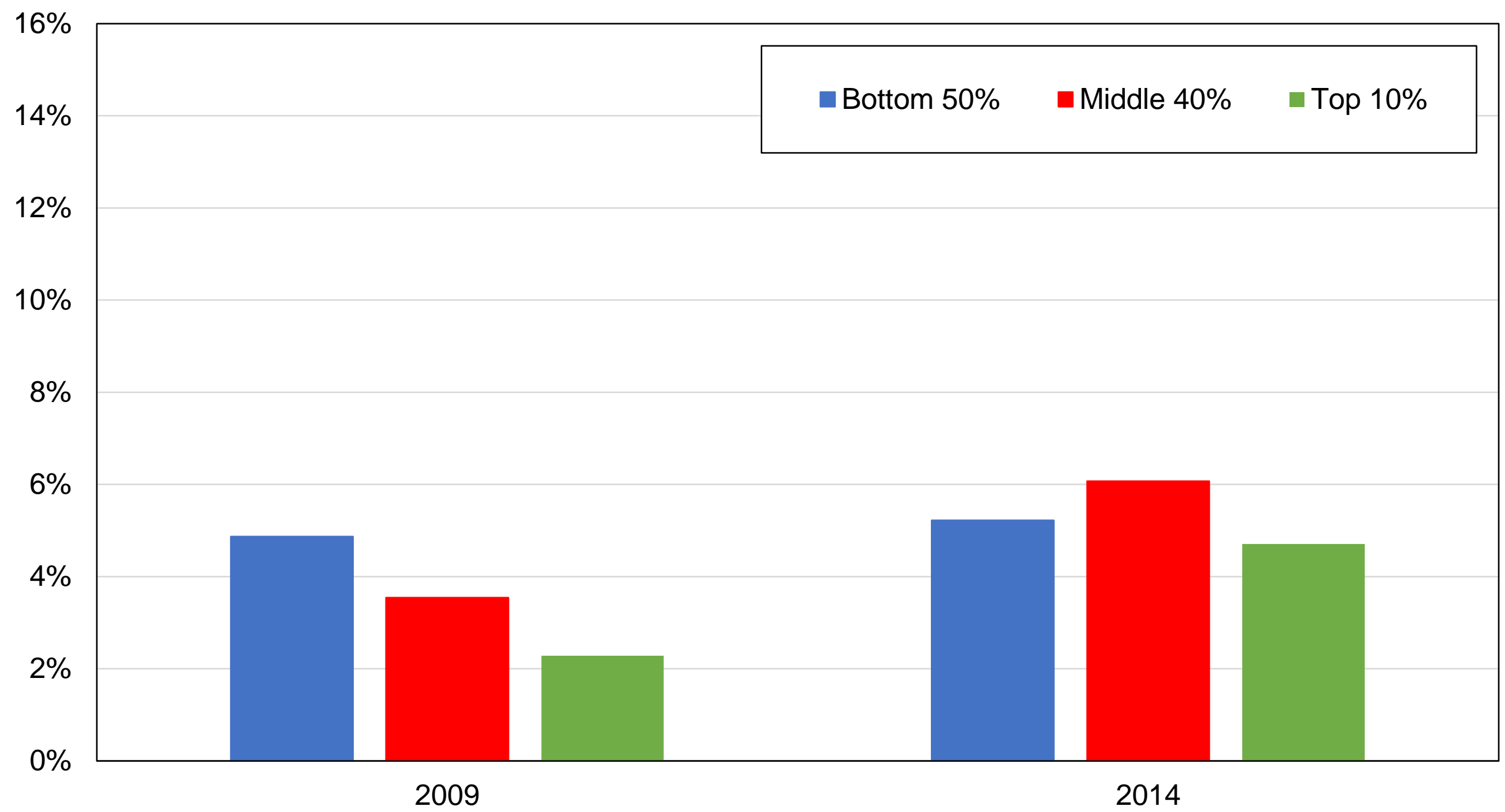

Source: authors' computations using Indonesian political attitudes surveys.

Note: the figure shows the share of votes received by Hanura by income group. 


\section{Figure DG4 - Vote for Hanura among top-income voters}

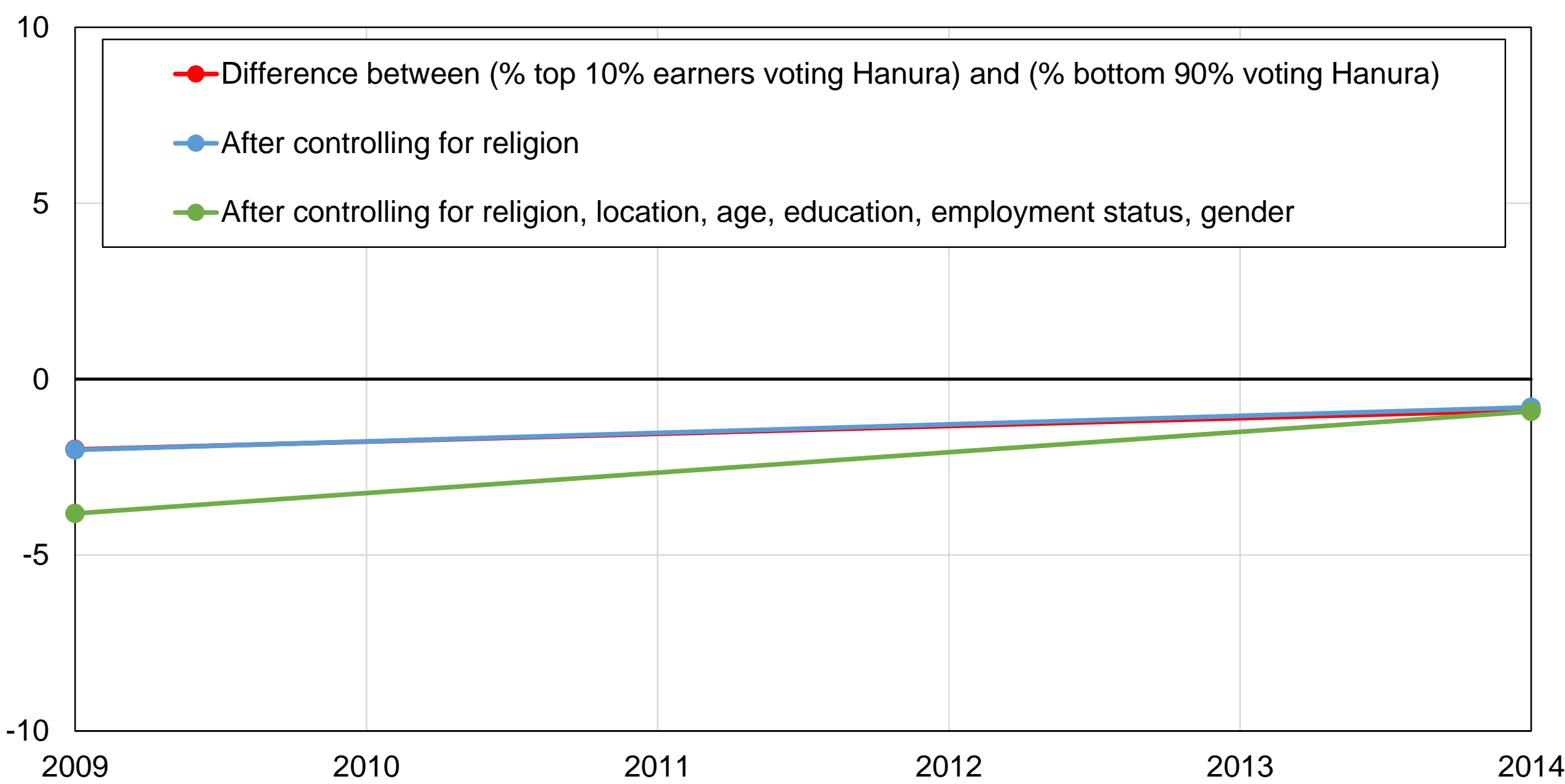

Source: authors' computations using Indonesian political attitudes surveys.

Note: the figure shows the difference between the share of top $10 \%$ earners voting for Hanura and the share of other voters voting for Hanura, before and after controls. 
Figure DG5 - Vote for Hanura by religion

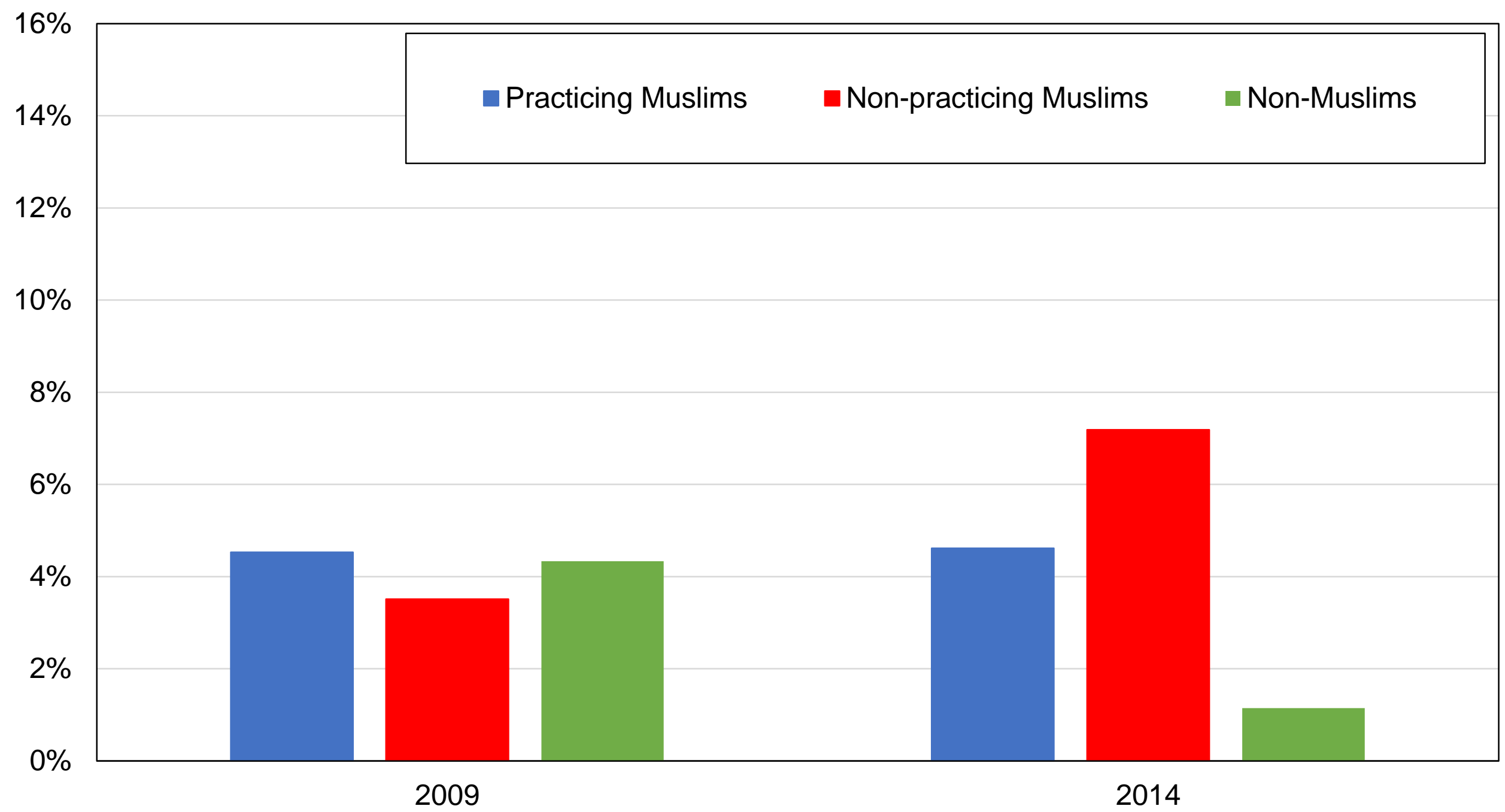

Source: authors' computations using Indonesian political attitudes surveys. Note: the figure shows the share of votes received by Hanura by religion. 


\section{Figure DG6 - Vote for Hanura among practicing Muslims}

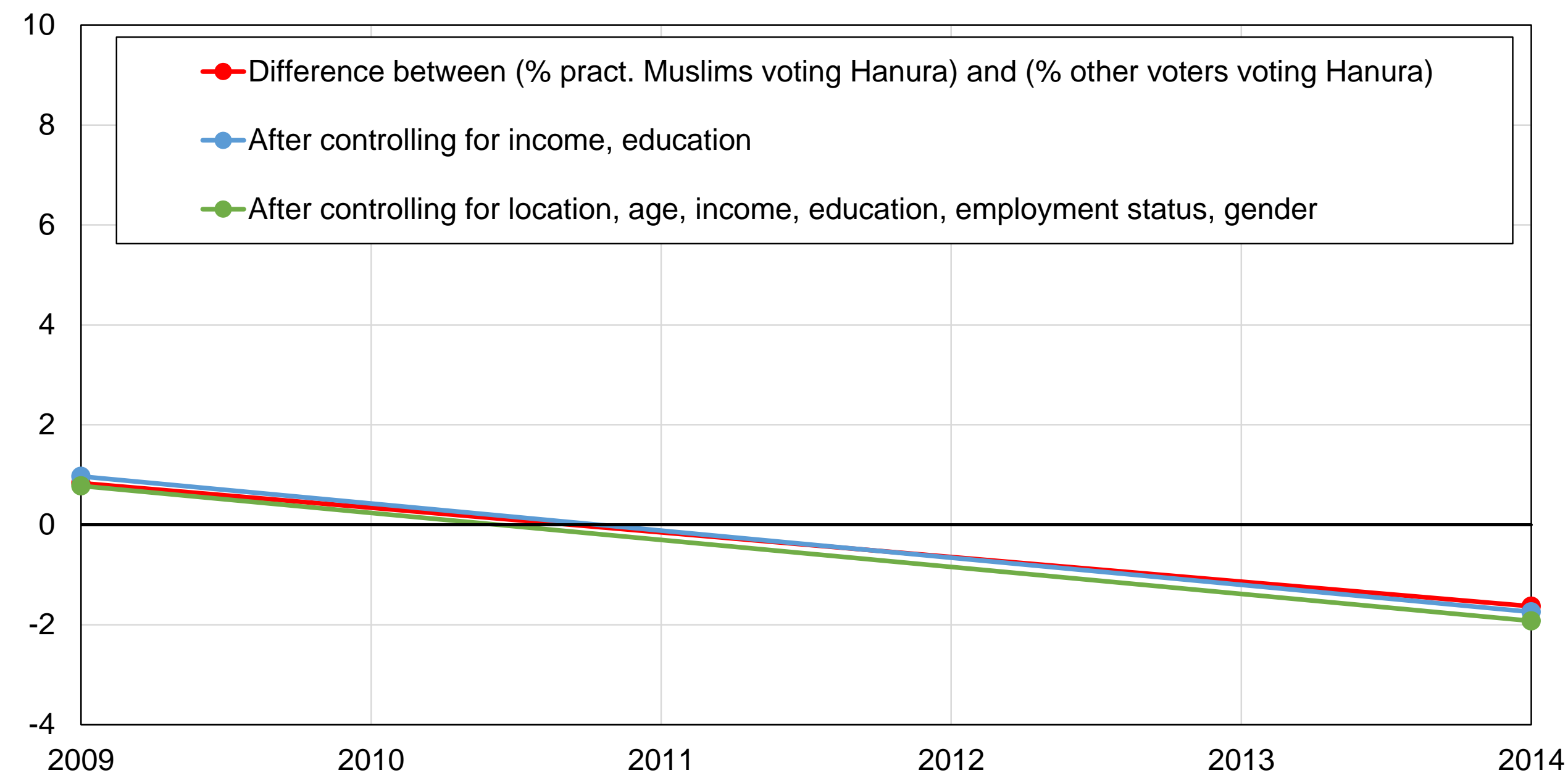

Source: authors' computations using Indonesian political attitudes surveys.

Note: the figure shows the difference between the share of practicing Muslims voting for Hanura and the share of other voters voting for Hanura, before and after controls. 
Figure DG7 - Vote for Hanura by age group

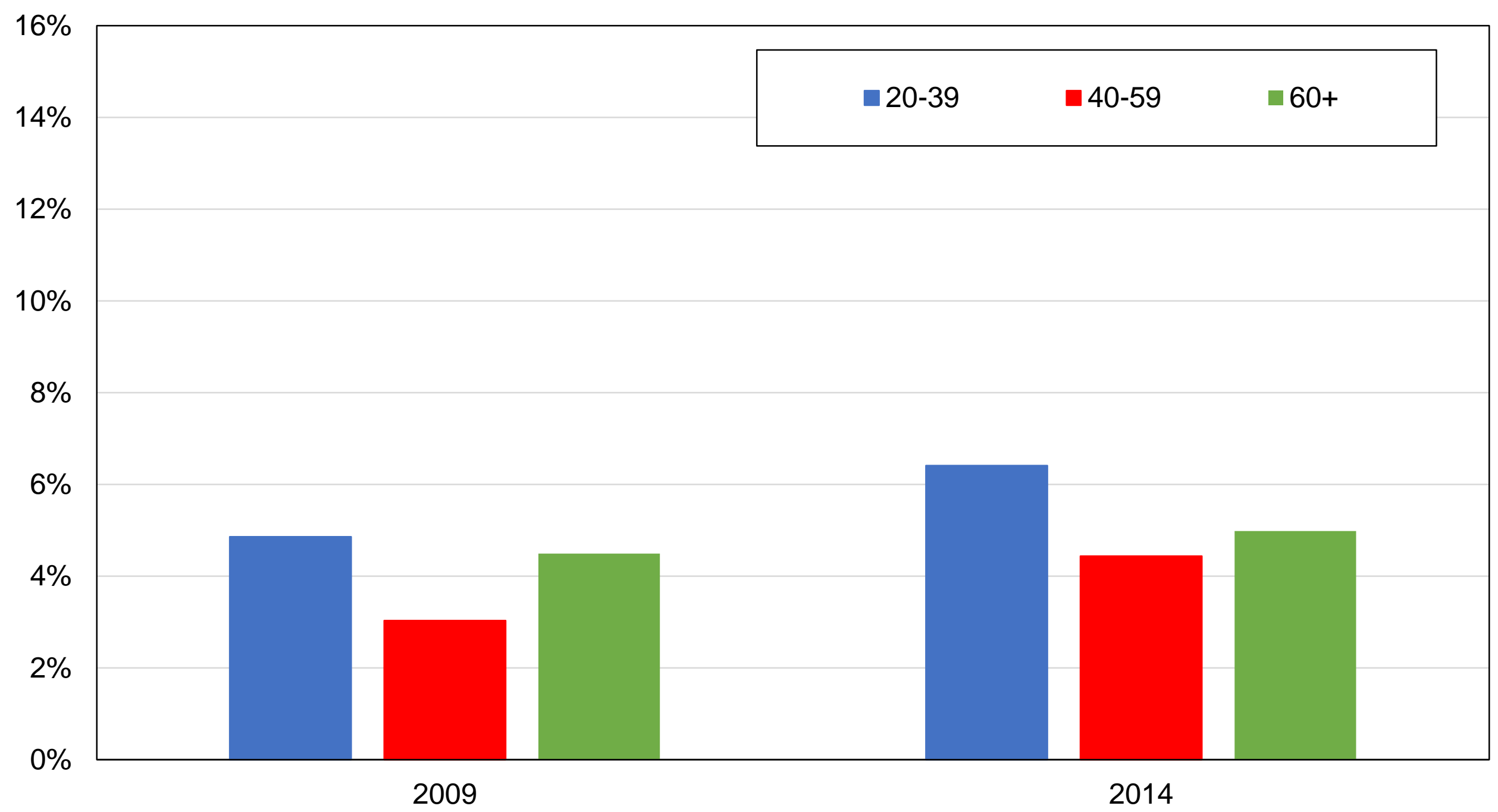

Source: authors' computations using Indonesian political attitudes surveys.

Note: the figure shows the share of votes received by Hanura by age group. 


\section{Figure DG8 - Vote for Hanura among young voters}

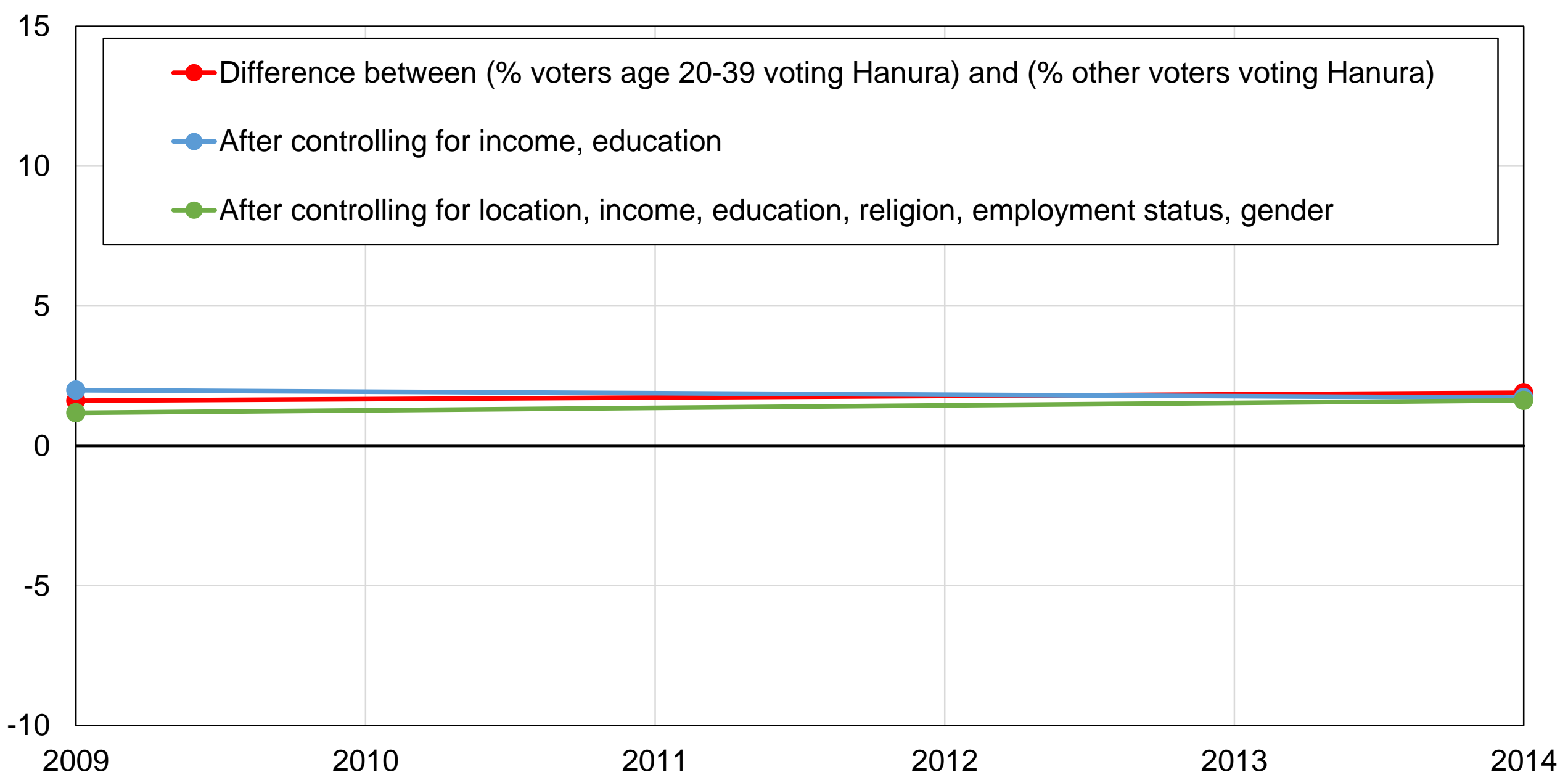

Source: authors' computations using Indonesian political attitudes surveys.

Note: the figure shows the difference between share of young voters voting for Hanura and the share of other voters voting for Hanura, before and after controls. 
Figure DG9 - Vote for Hanura by rural-urban location

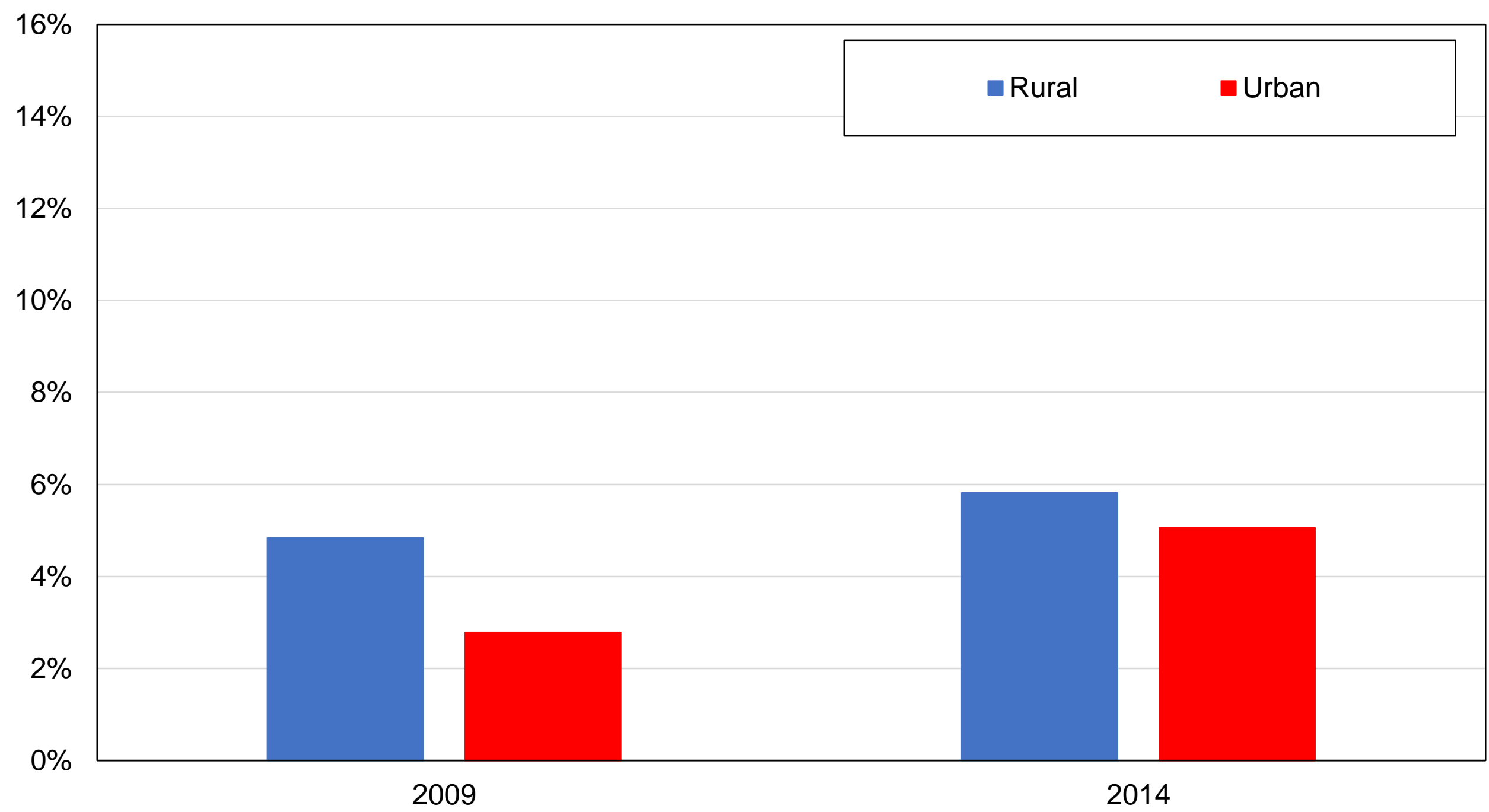

Source: authors' computations using Indonesian political attitudes surveys.

Note: the figure shows the share of votes received by Hanura by rural-urban location. 


\section{Figure DG10 - Vote for Hanura among urban voters}

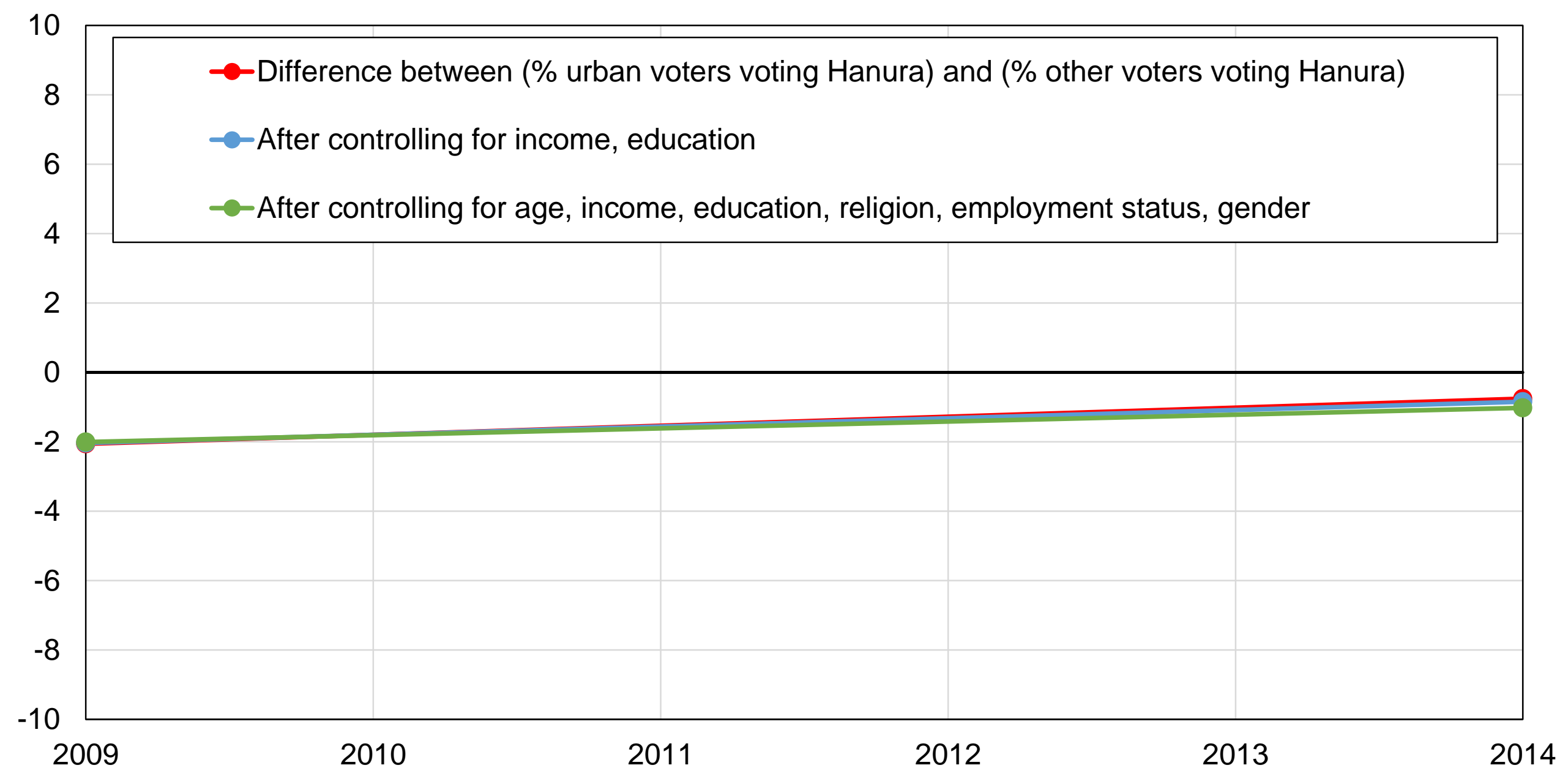

Source: authors' computations using Indonesian political attitudes surveys.

Note: the figure shows the difference between the share of urban voters voting for Gerindra and the share of other voters voting for Gerindra, before and after controls. 


\section{Figure DH1 - Vote for Golkar by education level}

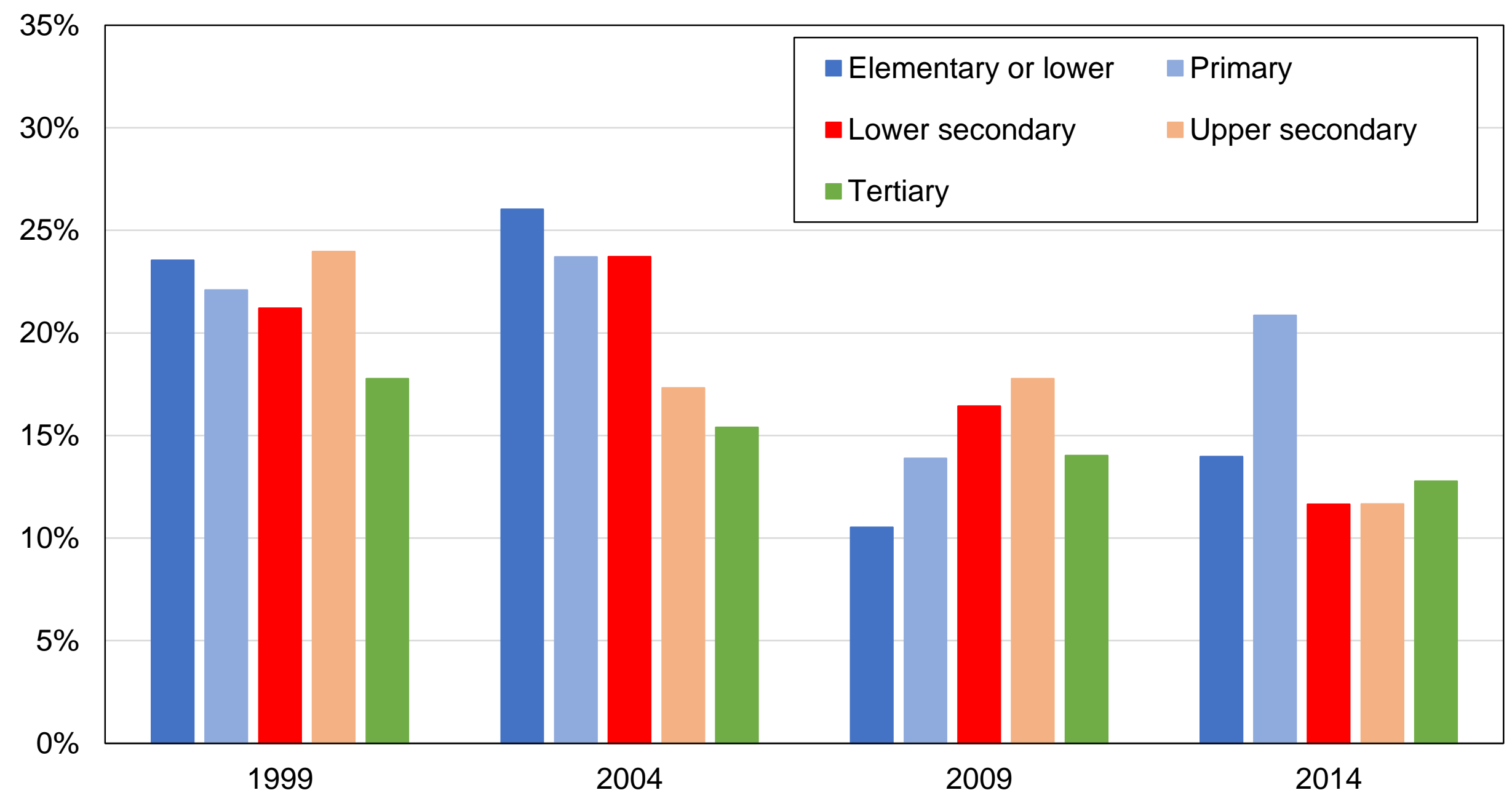

Source: authors' computations using Indonesian political attitudes surveys.

Note: the figure shows the share of votes received by Golkar by education level. 


\section{Figure DH2 - Vote for Golkar among higher-educated voters}

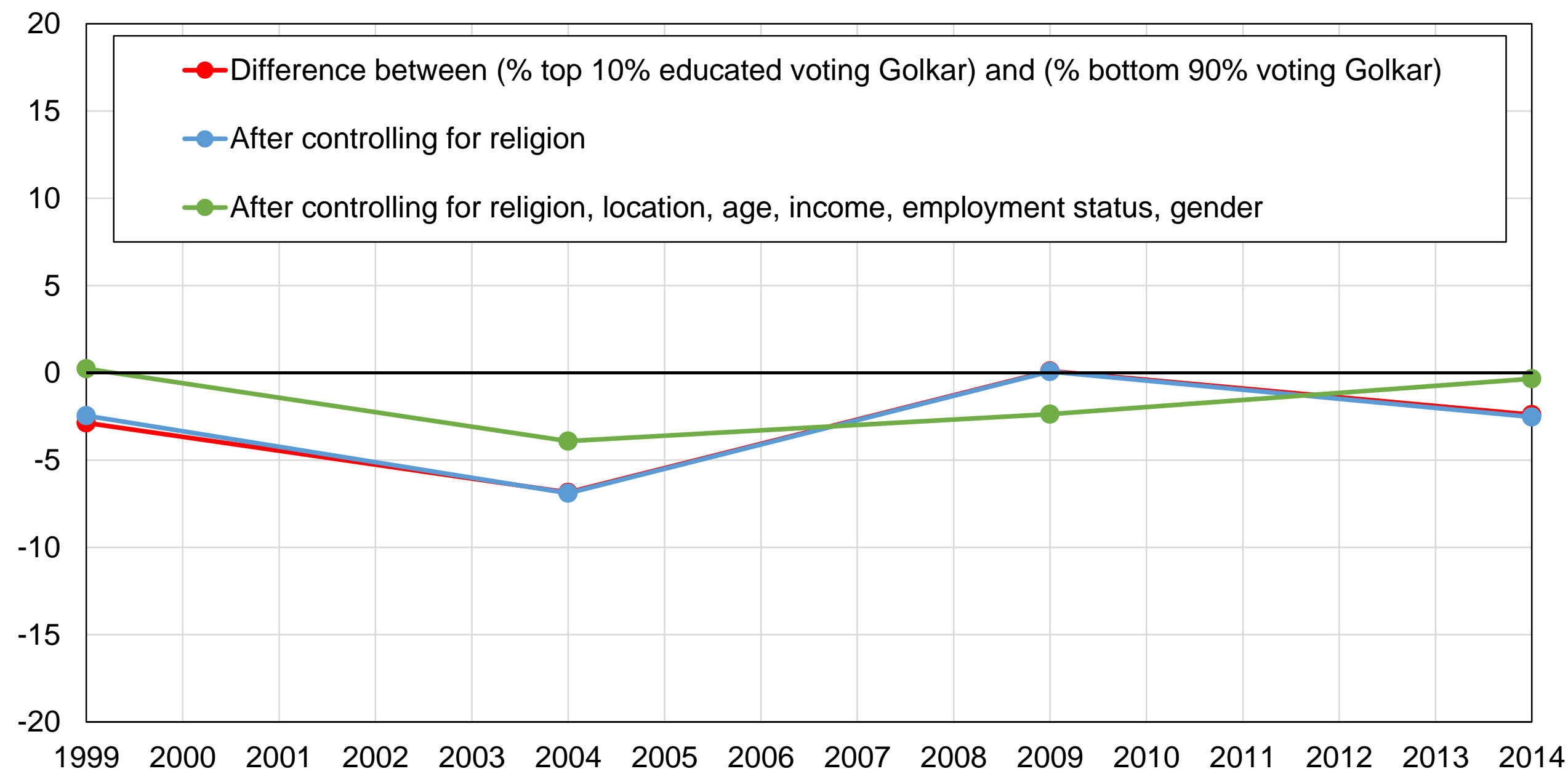

Source: authors' computations using Indonesian political attitudes surveys.

Note: the figure shows the difference between the share of top $10 \%$ educated voters voting for Golkar and the share of other voters voting for Golkar, before and after controls. 
Figure DH3 - Vote for Golkar by income group

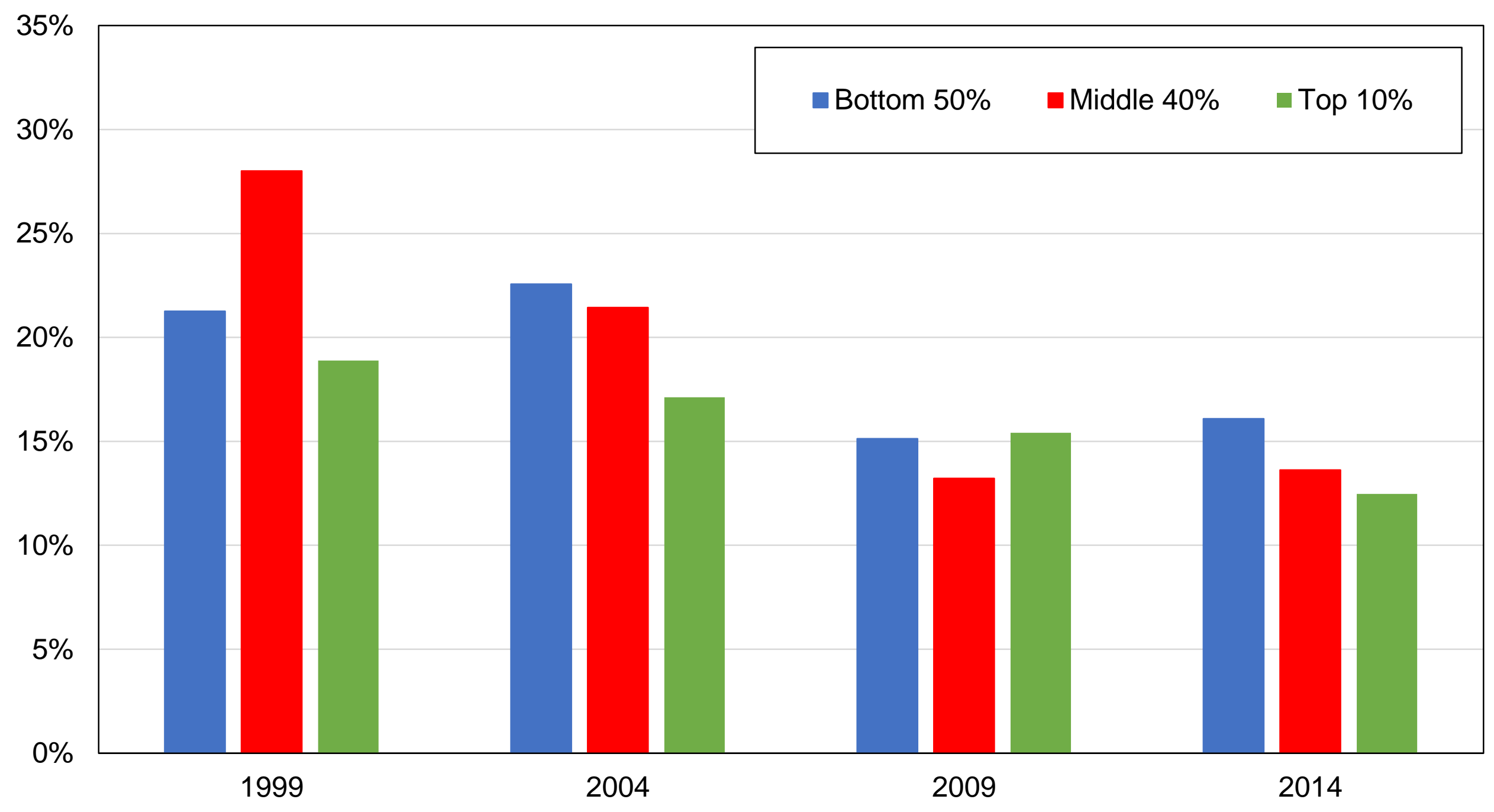

Source: authors' computations using Indonesian political attitudes surveys.

Note: the figure shows the share of votes received by Golkar by income group. 


\section{Figure DH4 - Vote for Golkar among top-income voters}

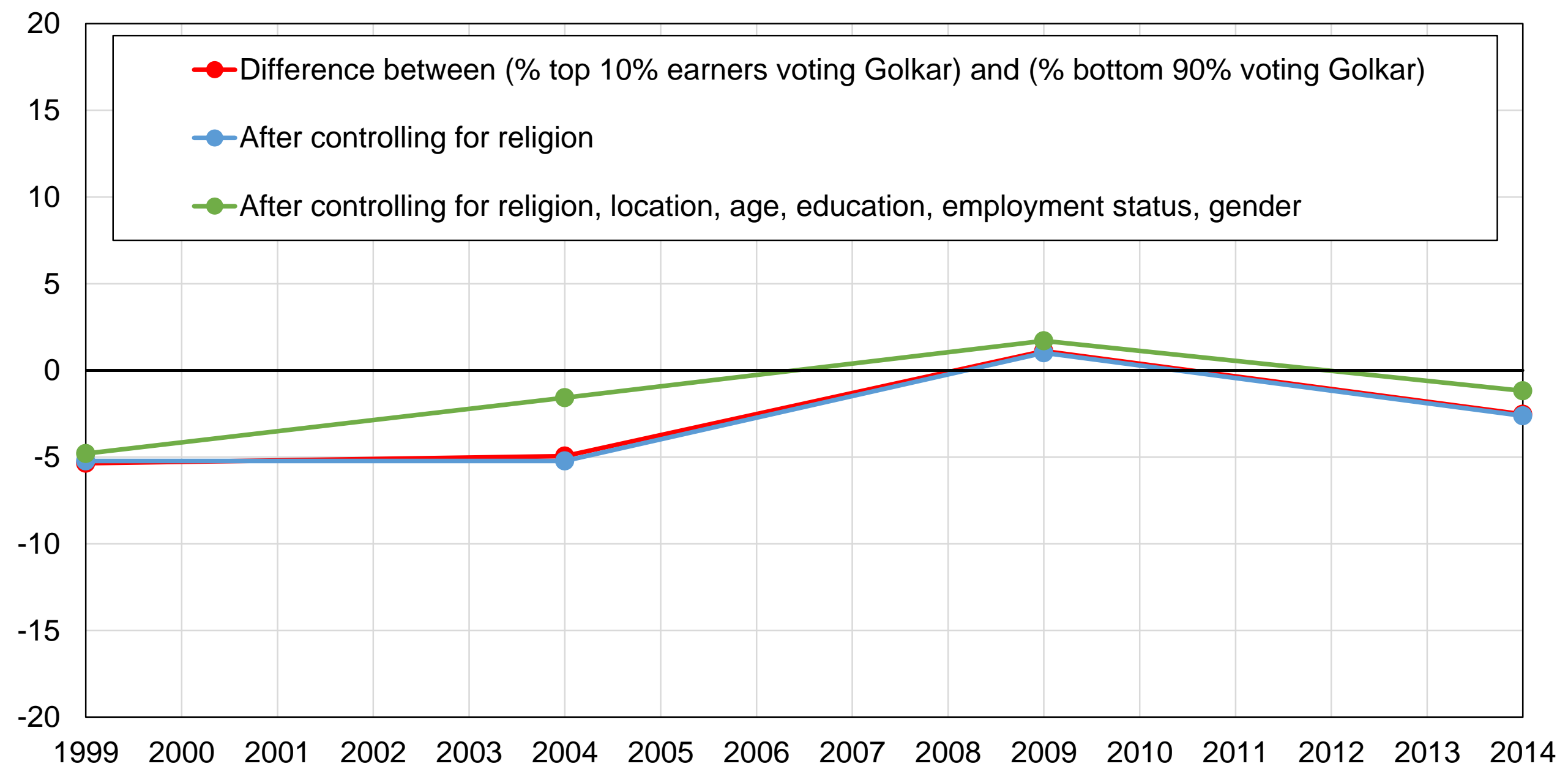

Source: authors' computations using Indonesian political attitudes surveys.

Note: the figure shows the difference between the share of top $10 \%$ earners voting for Golkar and the share of other voters voting for Golkar, before and after controls. 
Figure DH5 - Vote for Golkar by religion

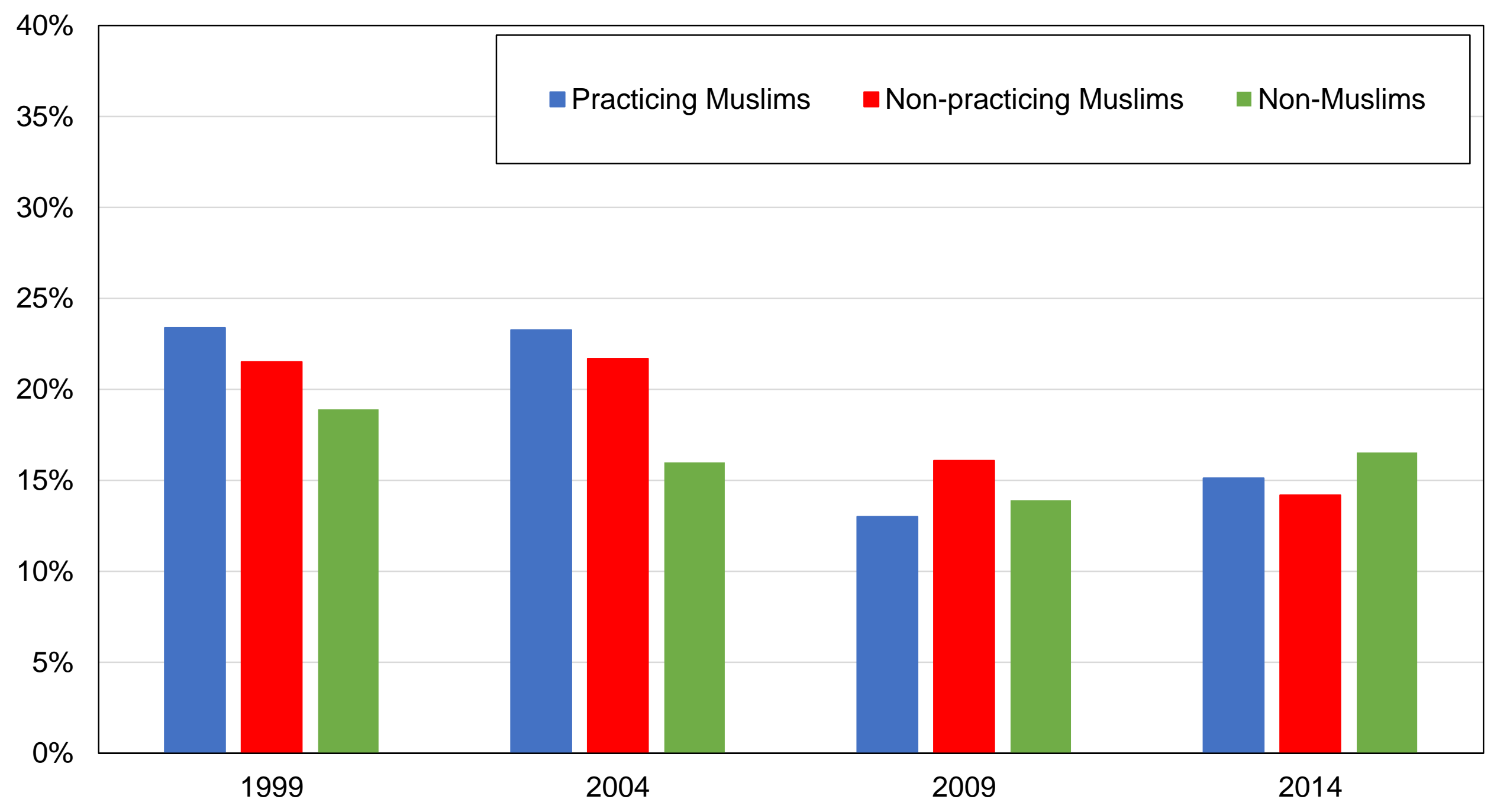

Source: authors' computations using Indonesian political attitudes surveys.

Note: the figure shows the share of votes received by Golkar by religion. 


\section{Figure DH6 - Vote for Golkar among practicing Muslims}

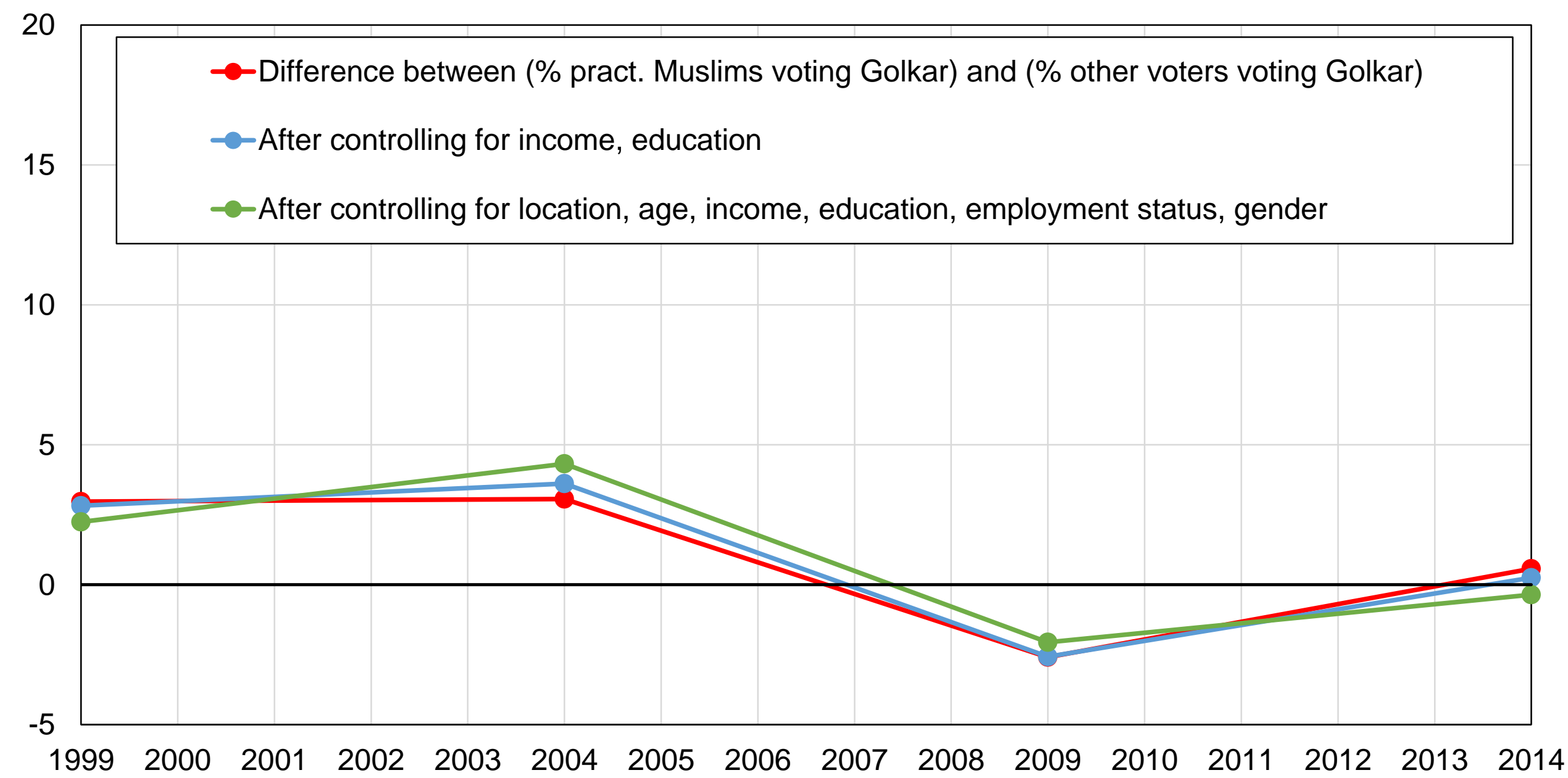

Source: authors' computations using Indonesian political attitudes surveys.

Note: the figure shows the difference between the share of practicing Muslims voting for Golkar and the share of other voters voting for Golkar, before and after controls. 
Figure DH7 - Vote for Golkar by age group

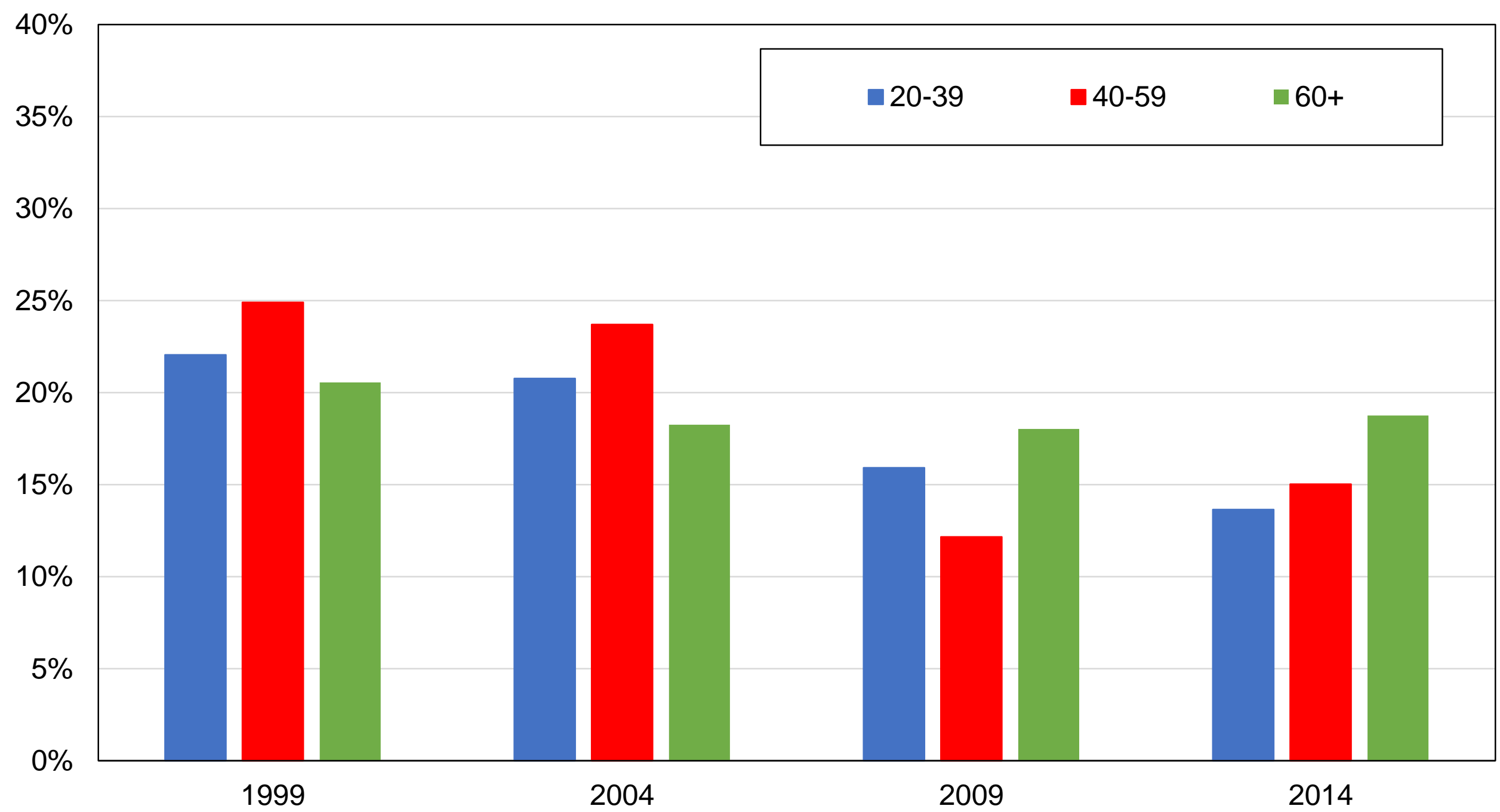

Source: authors' computations using Indonesian political attitudes surveys.

Note: the figure shows the share of votes received by Golkar/Gerindra/Hanura by age group. 


\section{Figure DH8 - Vote for Golkar among young voters}

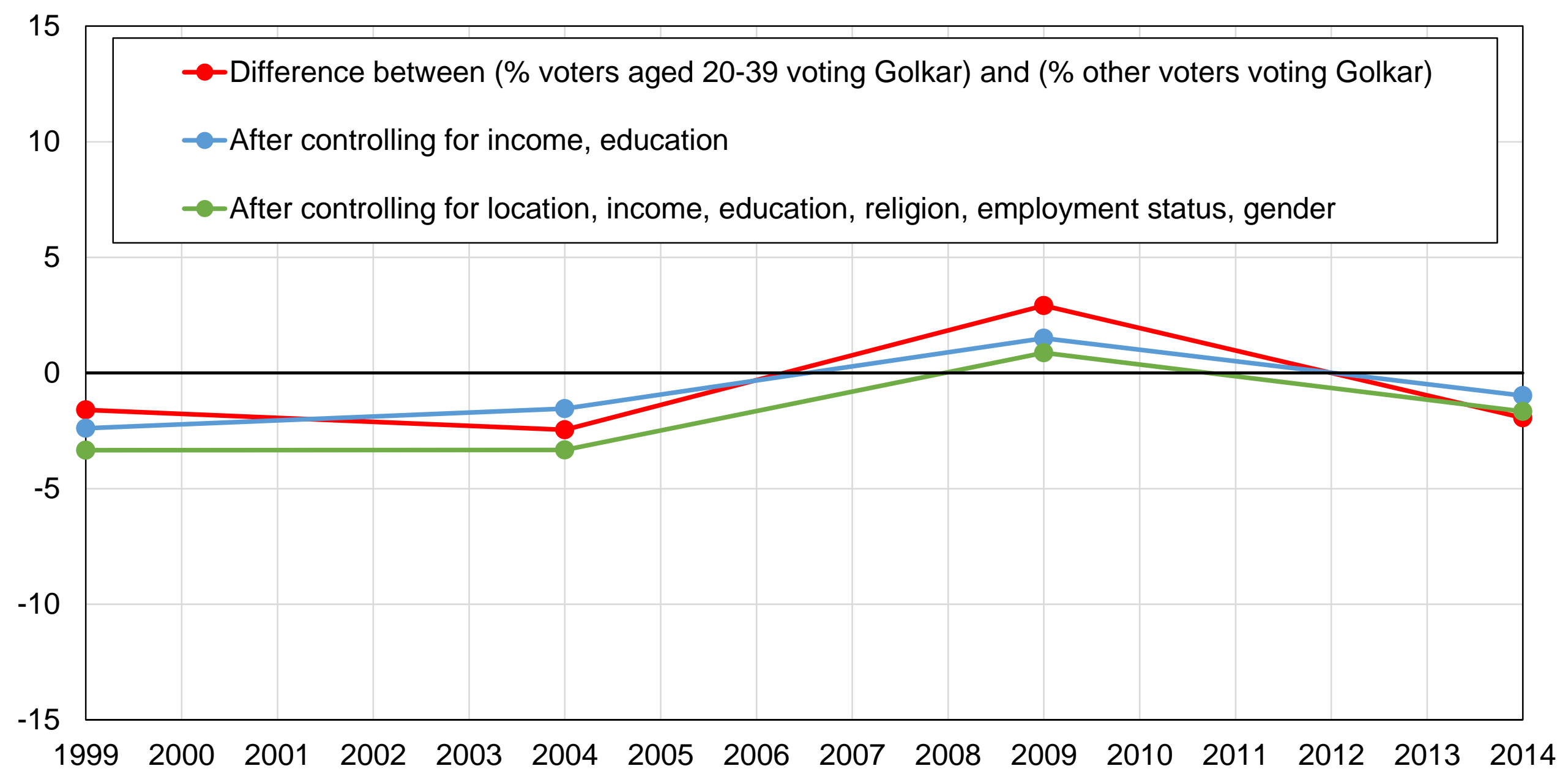

Source: authors' computations using Indonesian political attitudes surveys.

Note: the figure shows the difference between share of voters aged 20-40 voting for Golkar and the share of other voters voting for Golkar, before and after controls. 
Figure DH9 - Vote for Golkar by rural-urban location

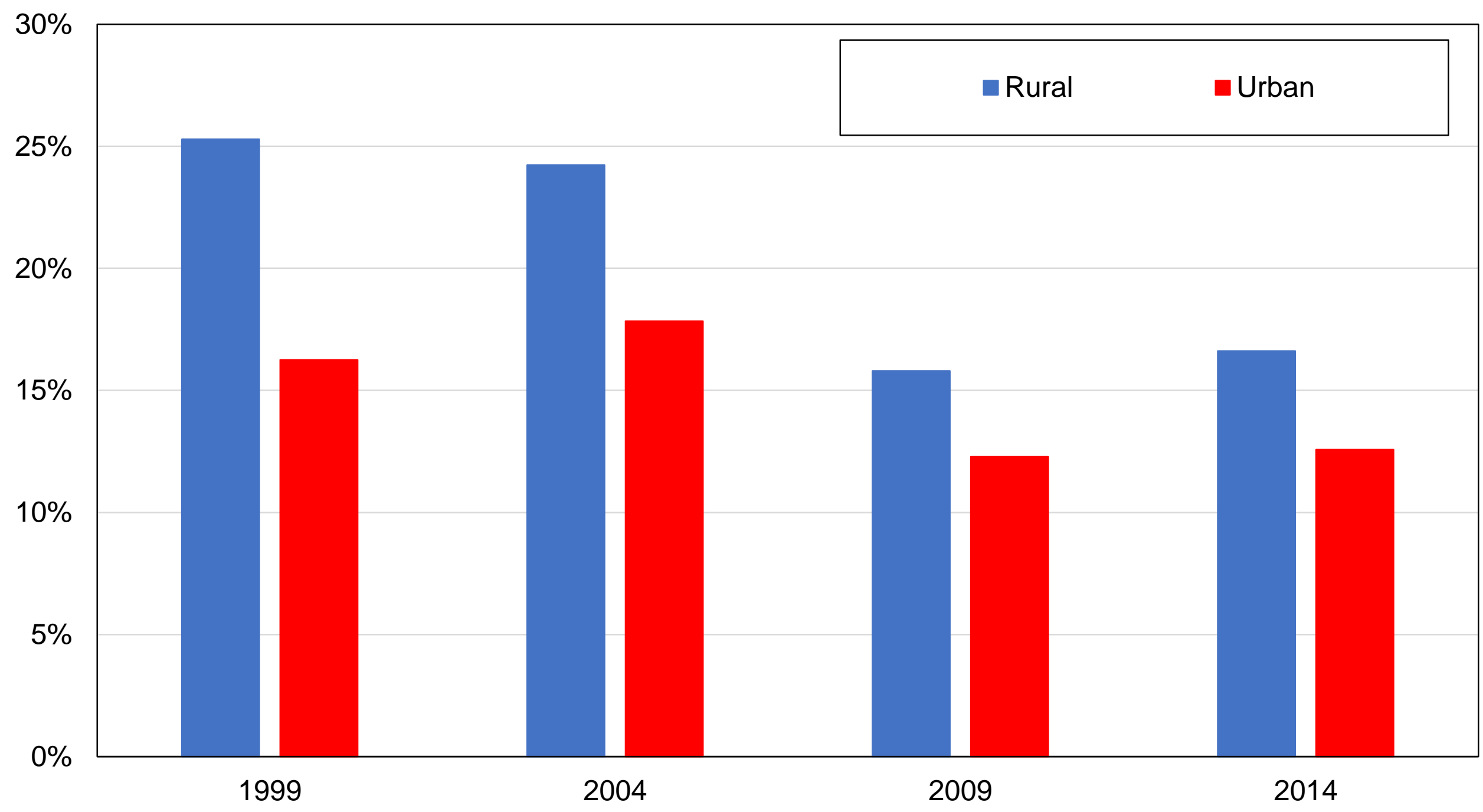

Source: authors' computations using Indonesian political attitudes surveys.

Note: the figure shows the share of votes received by Golkar by rural-urban location. 


\section{Figure DH10 - Vote for Golkar among urban voters}

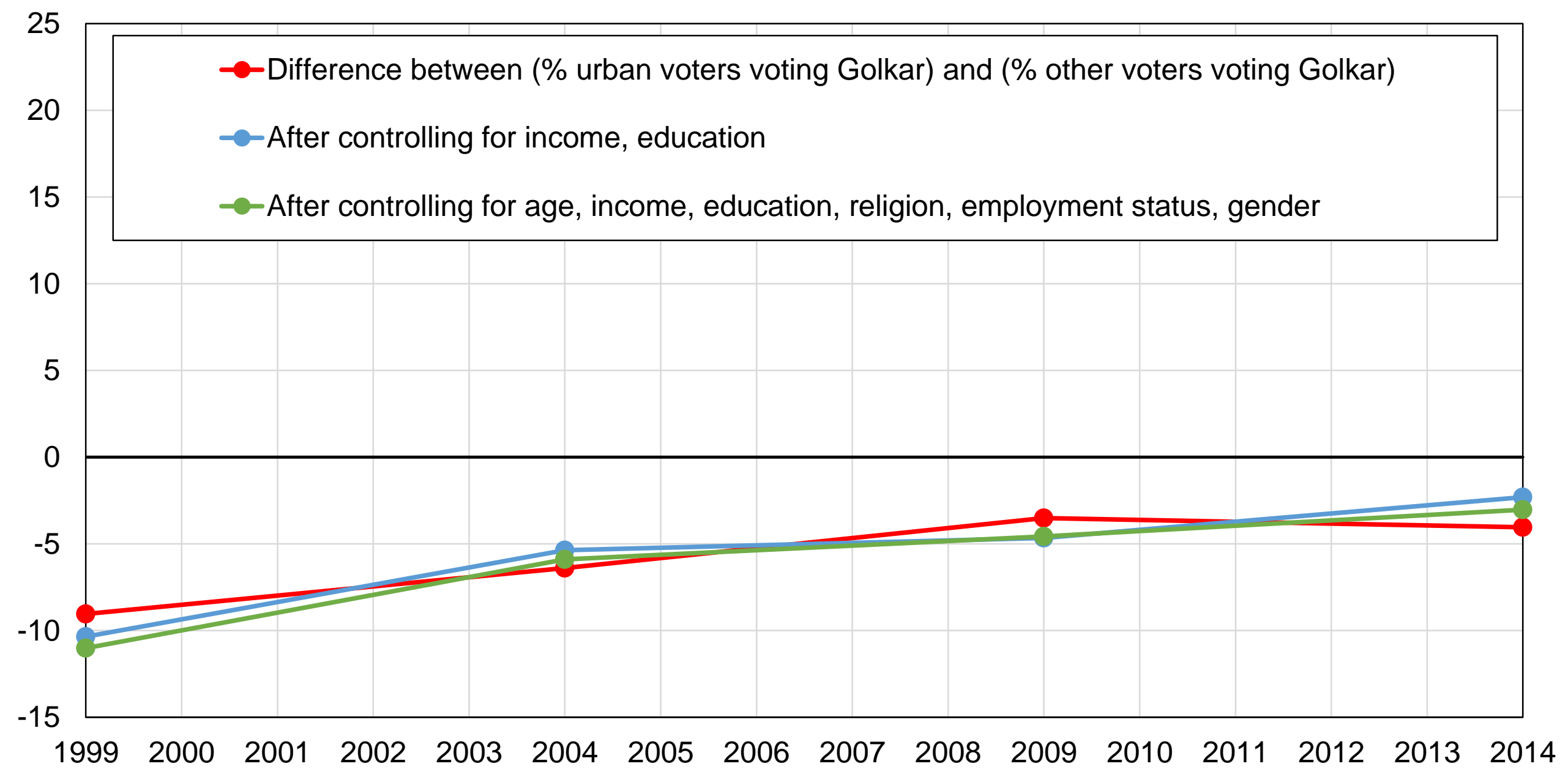

Source: authors' computations using Indonesian political attitudes surveys.

Note: the figure shows the difference between the share of urban voters voting for Golkar and the share of other voters voting for Golkar, before and after controls. 
Figure DH11 - Vote for Golkar by ethnicity

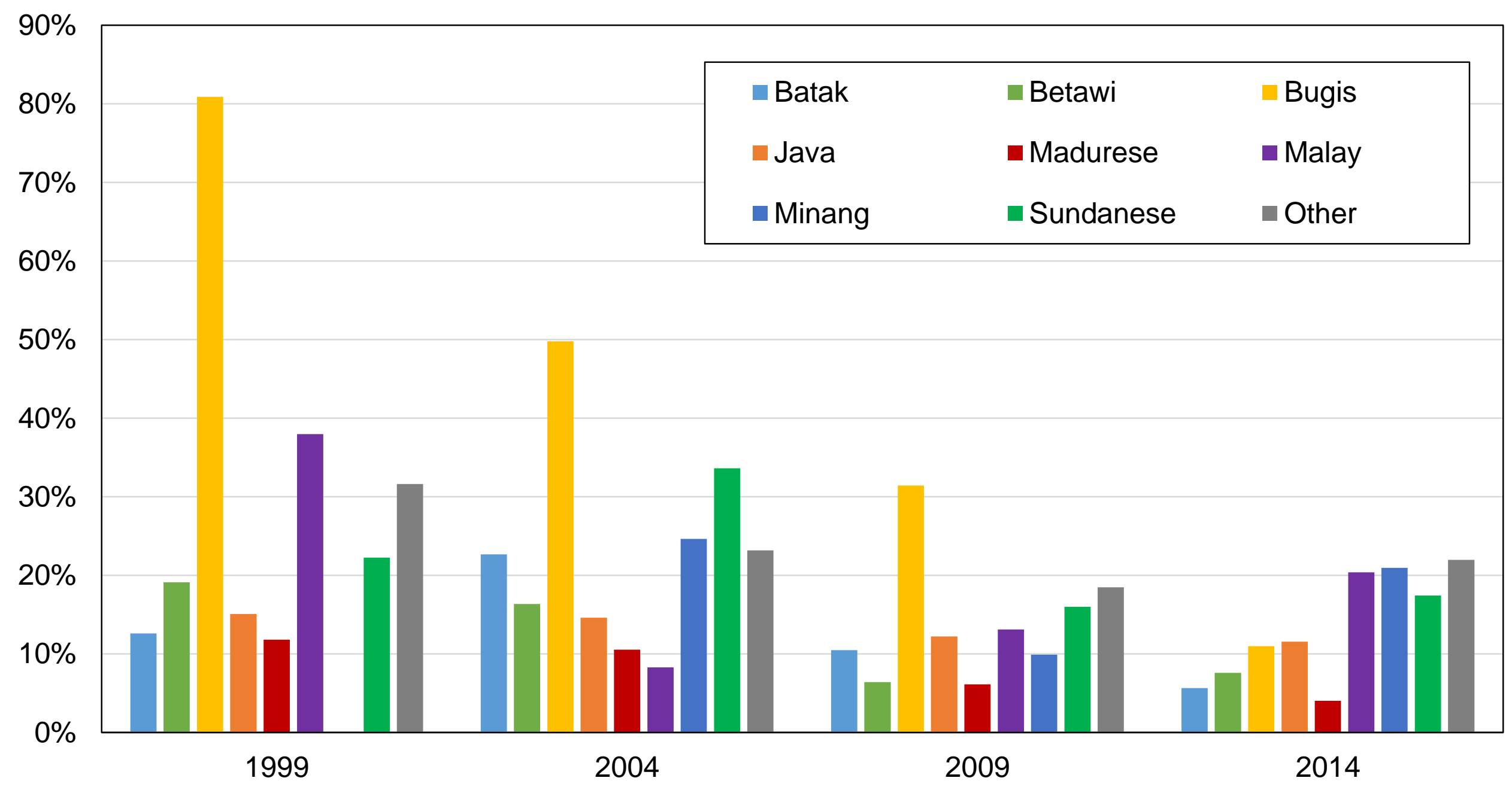

Source: authors' computations using Indonesian political attitudes surveys.

Note: the figure shows the share of votes received by Golkar by ethnic affiliation. 


\section{Figure DH12 - Vote for Golkar among Javanese voters}

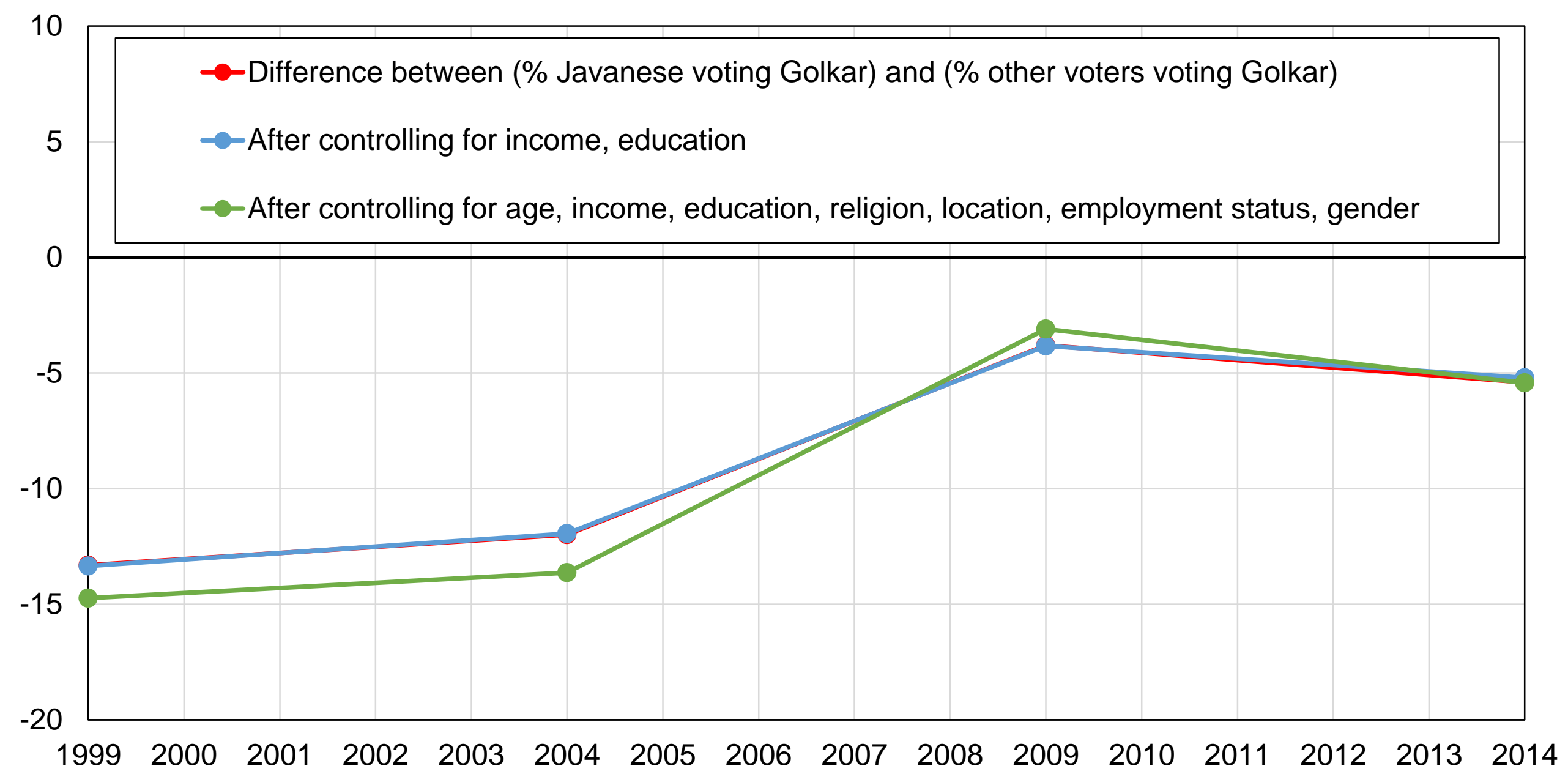

Source: authors' computations using Indonesian political attitudes surveys.

Note: the figure shows the difference between the share of Javanese voters voting for Golkar and the share of other voters voting for Golkar, before and after controls. 


\section{Figure DI1 - Vote for PDI-P by education level}

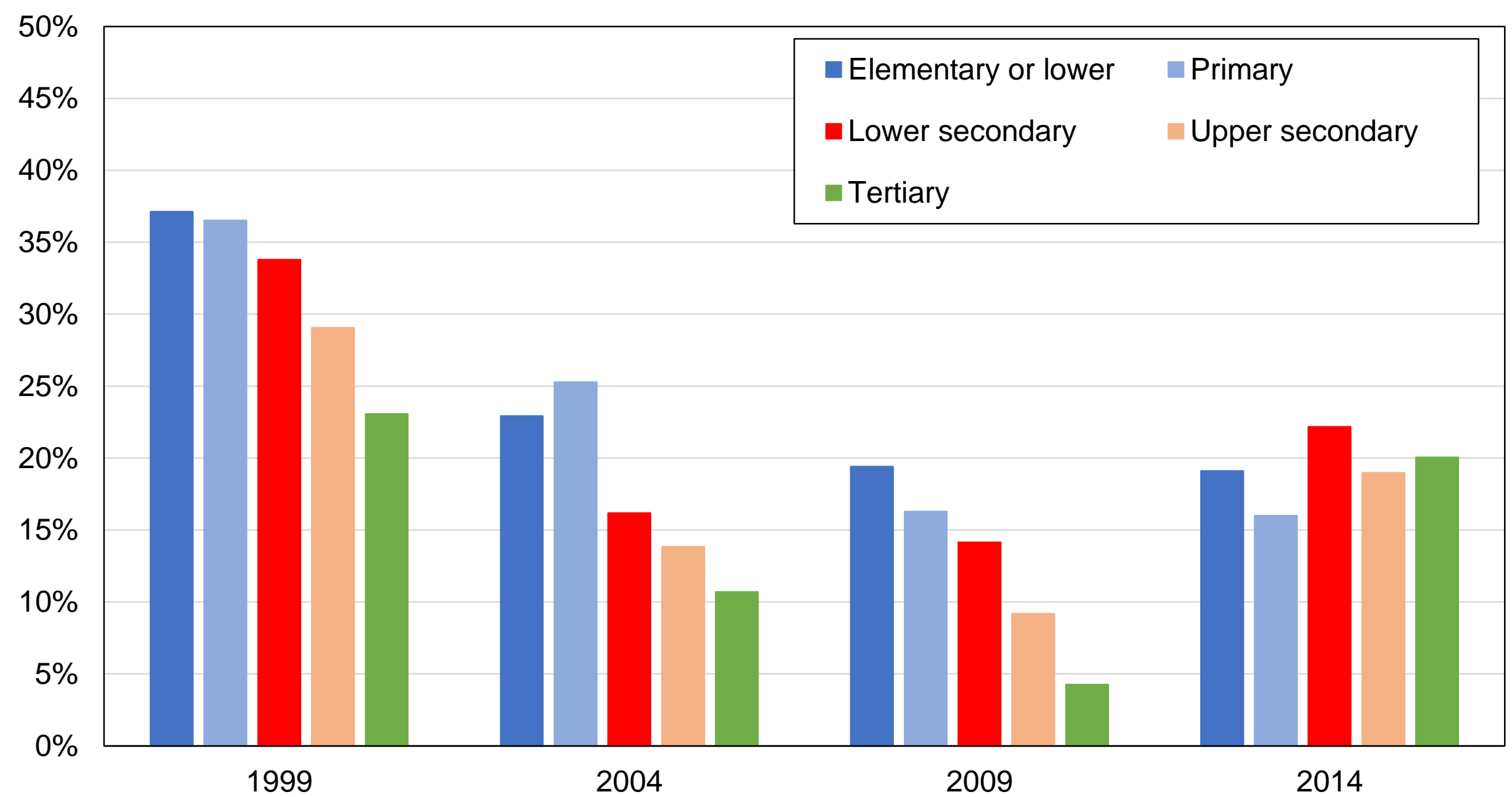

Source: authors' computations using Indonesian political attitudes surveys.

Note: the figure shows the share of votes received by PDI-P by education level. 


\section{Figure DI2 - Vote for PDI-P among higher-educated voters}

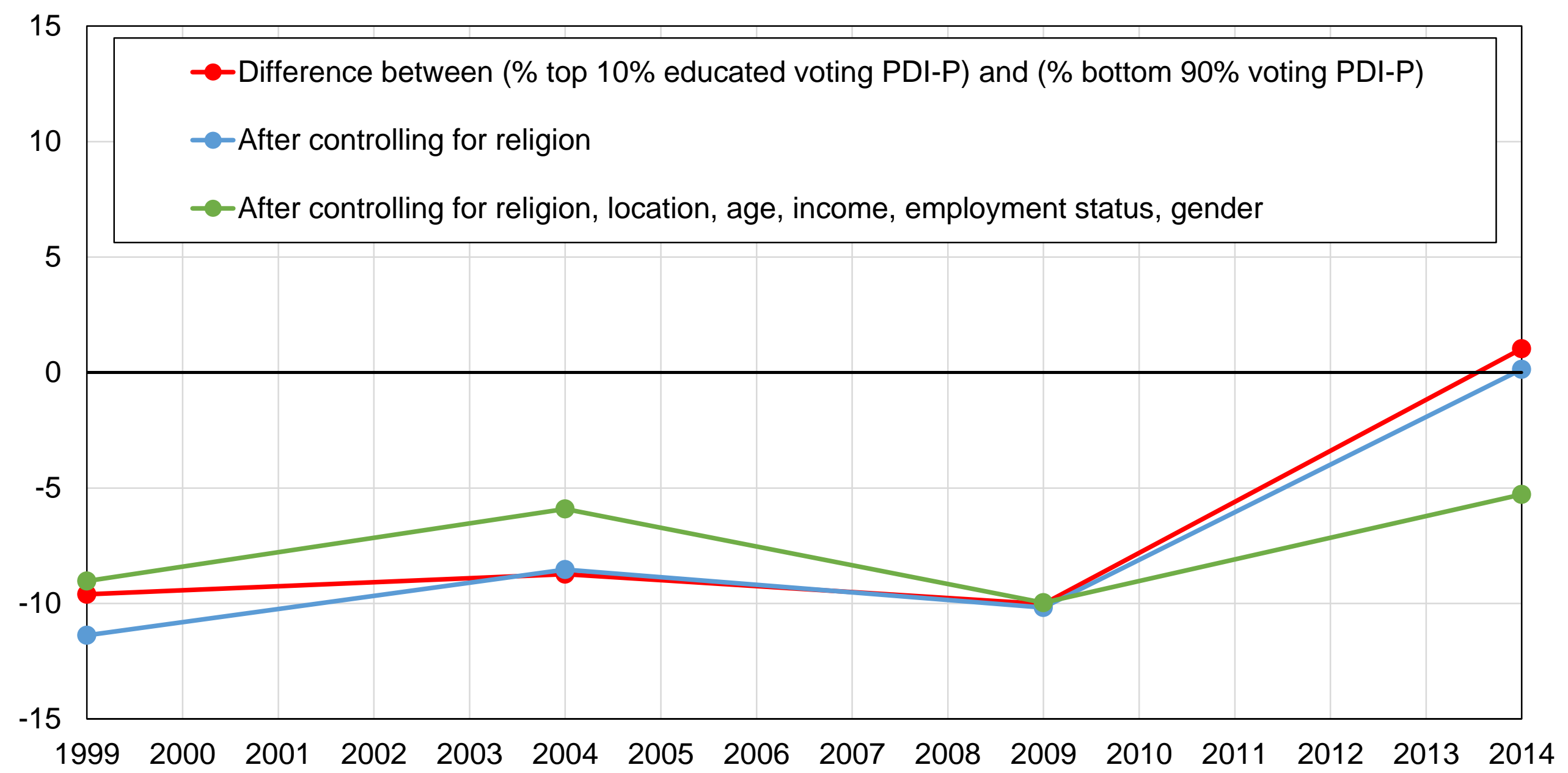

Source: authors' computations using Indonesian political attitudes surveys.

Note: the figure shows the difference between the share of top $10 \%$ educated voters voting for PDI-P and the share of other voters voting for PDI-P, before and after controls. 
Figure DI3 - Vote for PDI-P by income group

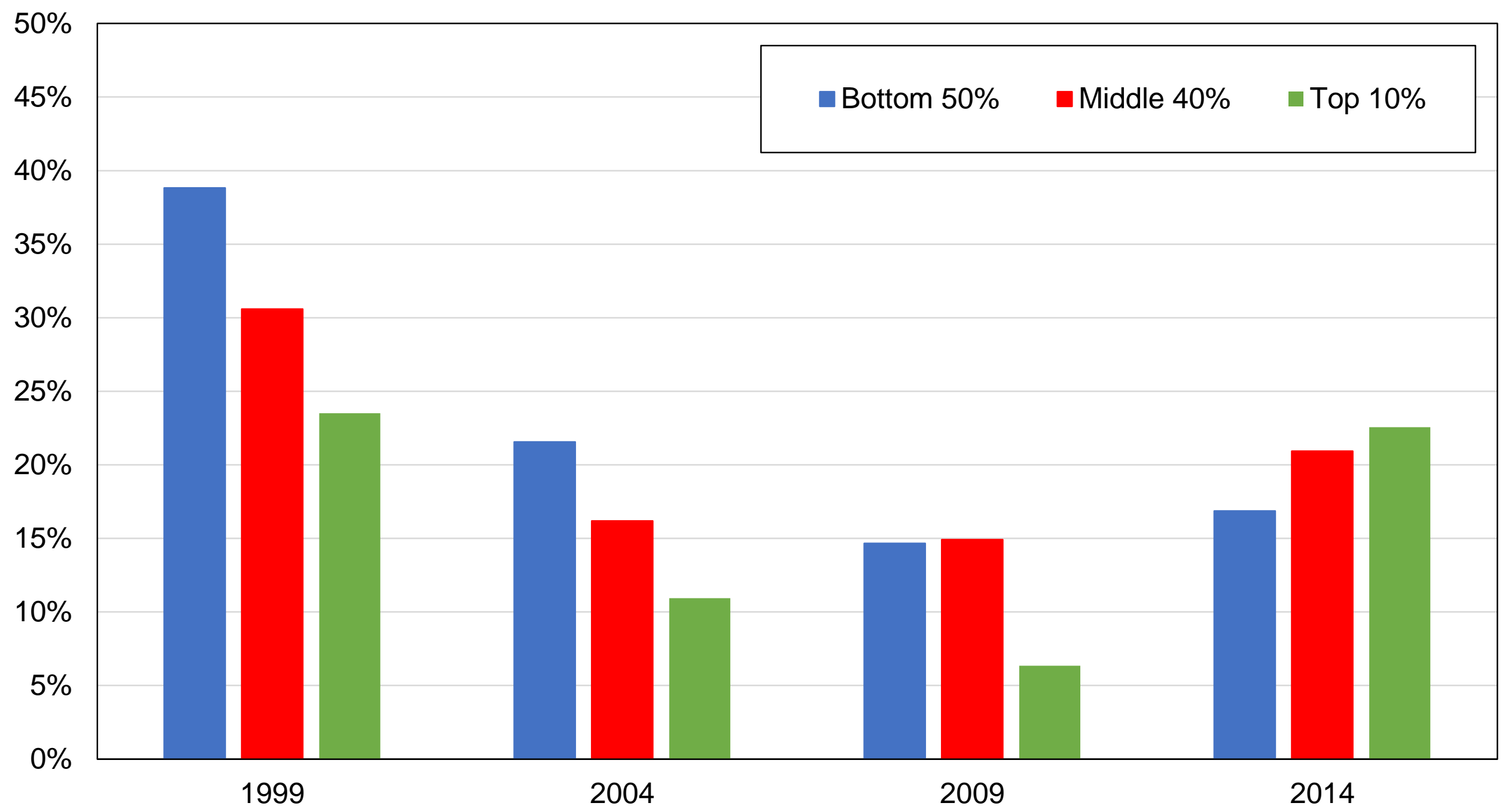

Source: authors' computations using Indonesian political attitudes surveys.

Note: the figure shows the share of votes received by PDI-P by income group. 


\section{Figure DI4 - Vote for PDI-P among top-income voters}

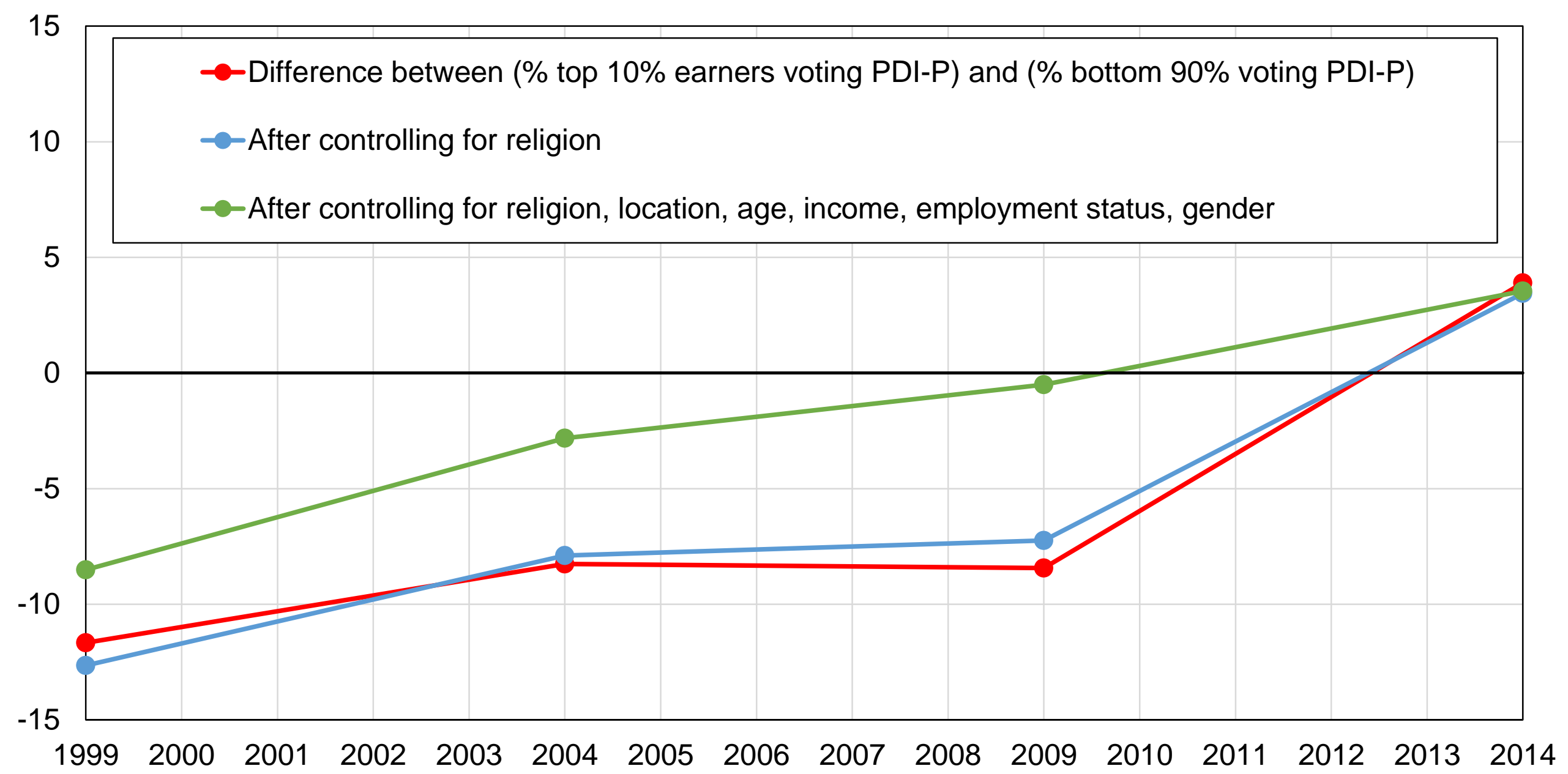

Source: authors' computations using Indonesian political attitudes surveys.

Note: the figure shows the difference between the share of top 10\% earners voting for PDI-P and the share of other voters voting for PDI-P, before and after controls. 
Figure DI5 - Vote for PDI-P by religion

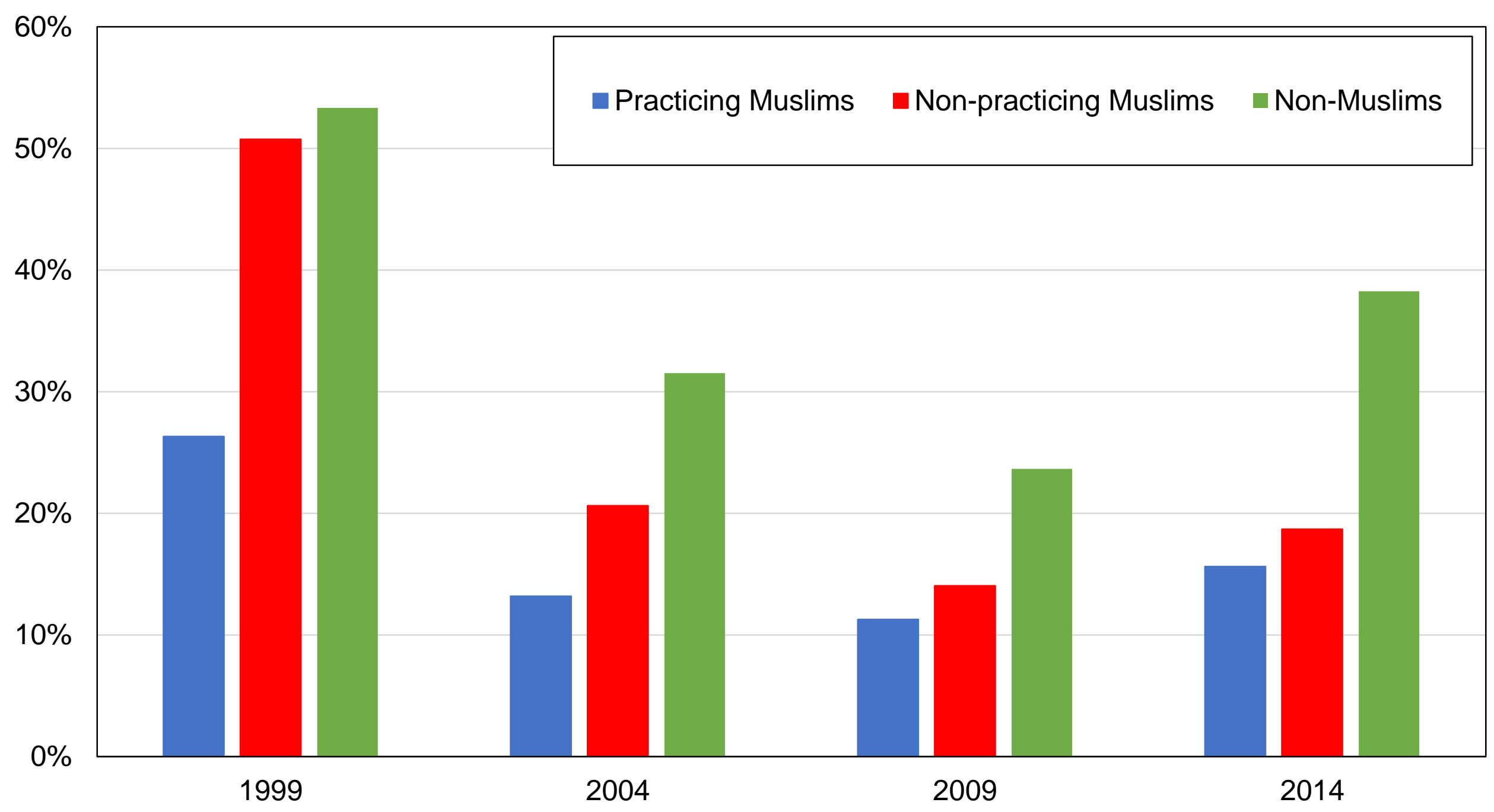

Source: authors' computations using Indonesian political attitudes surveys.

Note: the figure shows the share of votes received by PDI-P by religion. 


\section{Figure DI6 - Vote for PDI-P among practicing Muslims}

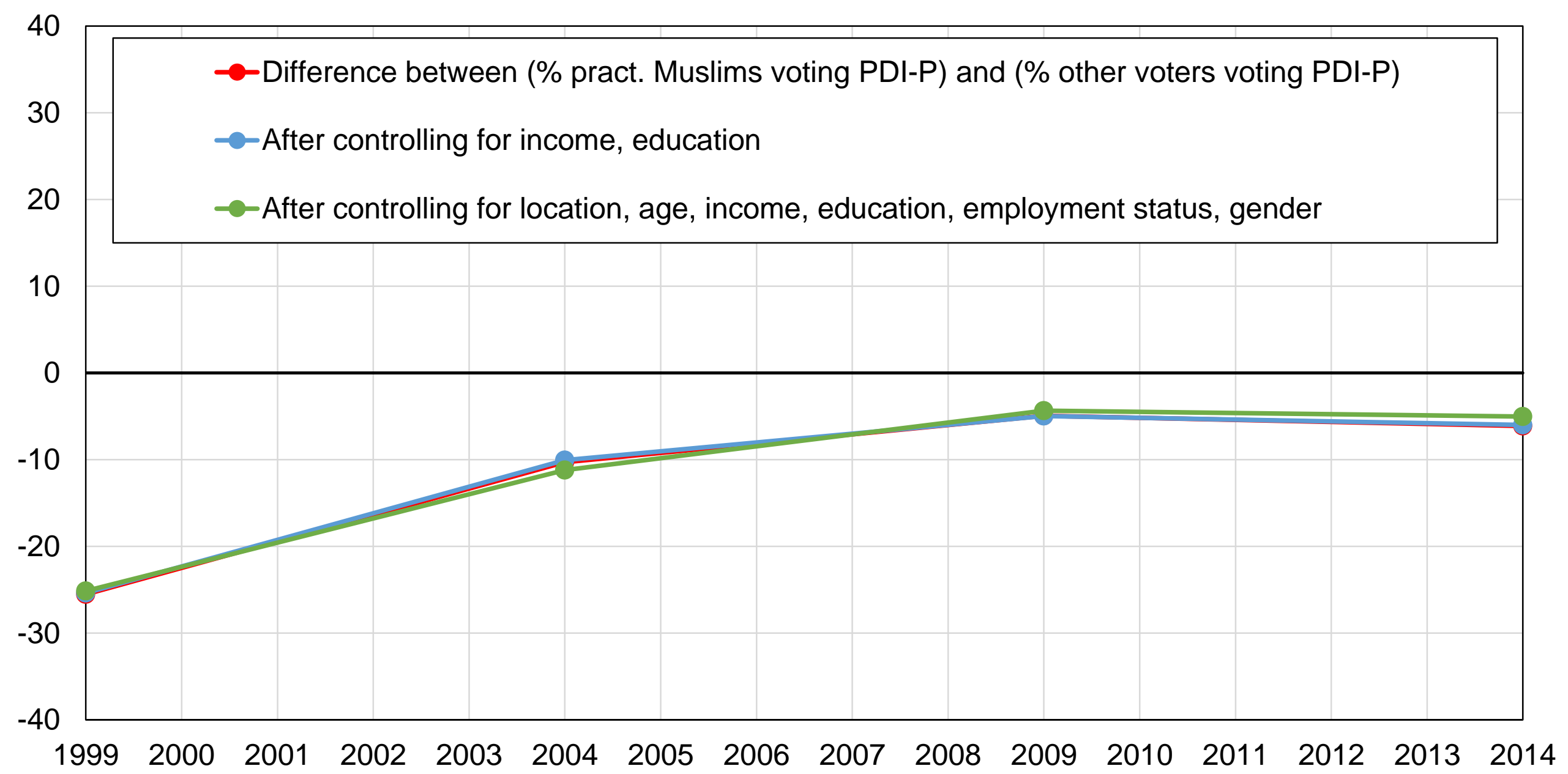

Source: authors' computations using Indonesian political attitudes surveys.

Note: the figure shows the difference between the share of practicing Muslims voting for PDI-P and the share of other voters voting for PDI-P, before and after controls. 


\section{Figure DI7 - Vote for PDI-P among young voters}

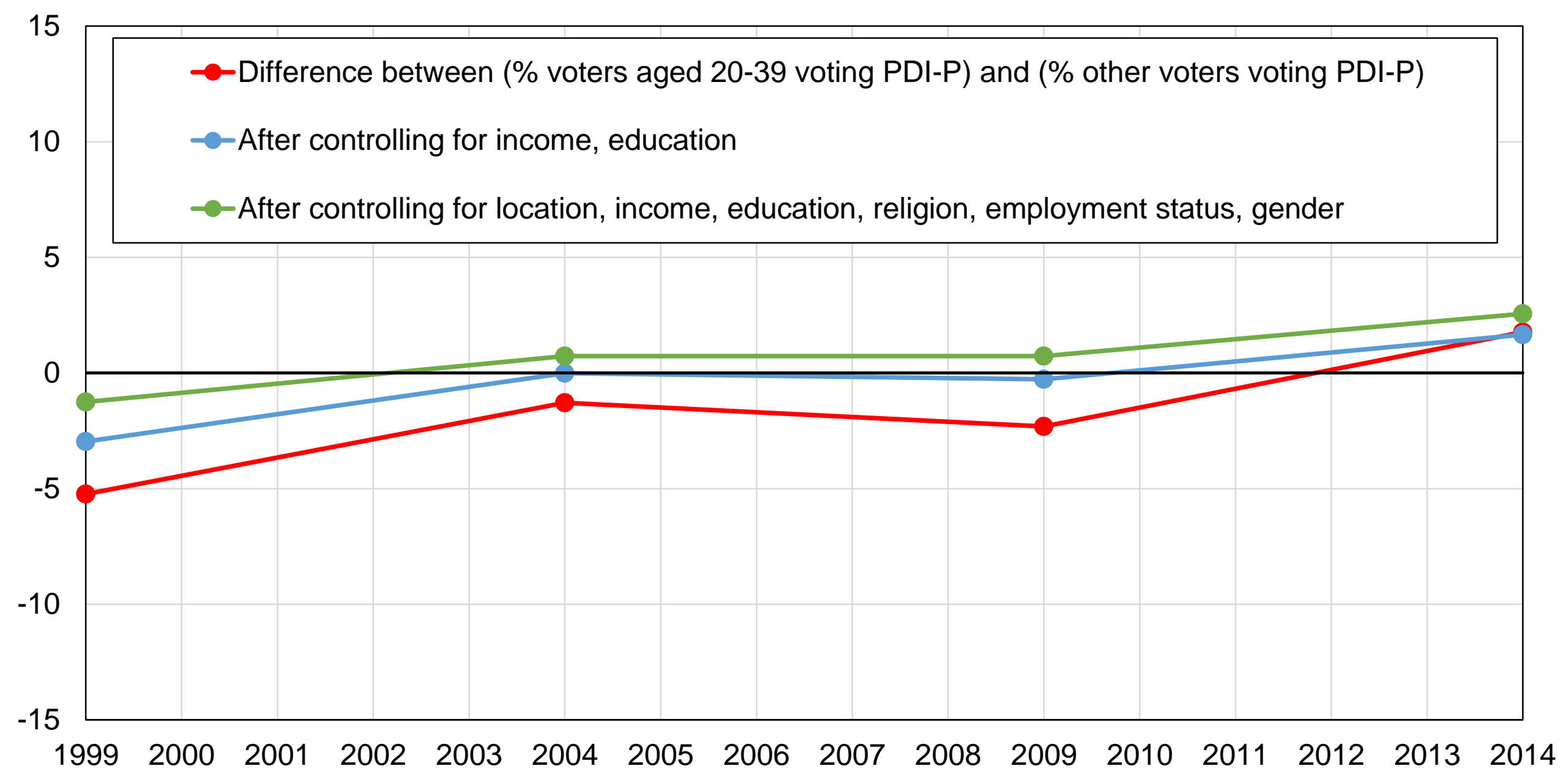

Source: authors' computations using Indonesian political attitudes surveys.

Note: the figure shows the difference between share of voters aged 20-40 voting for PDI-P and the share of other voters voting for PDI-P, before and after controls. 
Figure DI8 - Vote for PDI-P by rural-urban location

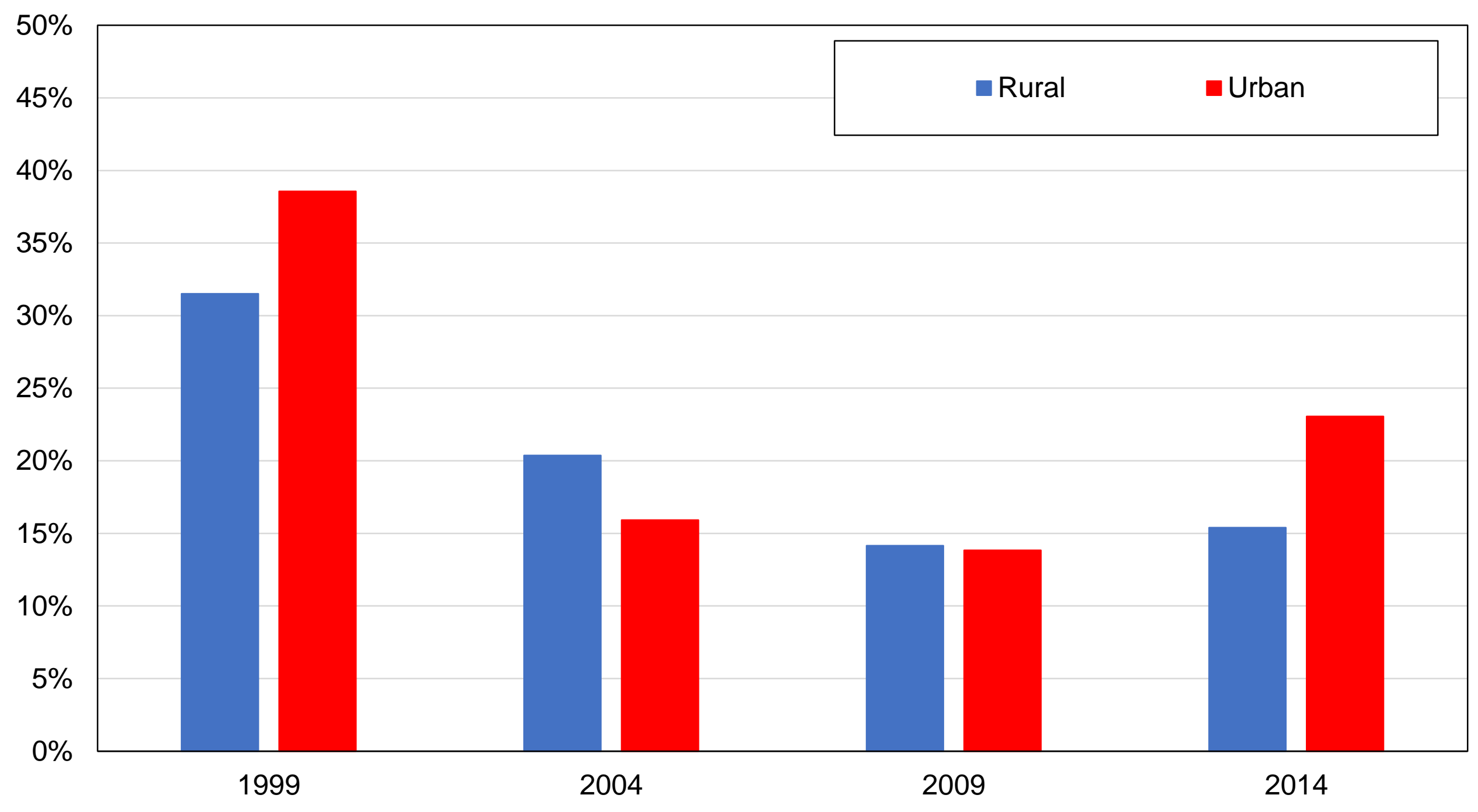

Source: authors' computations using Indonesian political attitudes surveys.

Note: the figure shows the share of votes received by PDI-P by rural-urban location. 


\section{Figure DI9 - Vote for PDI-P among urban voters}

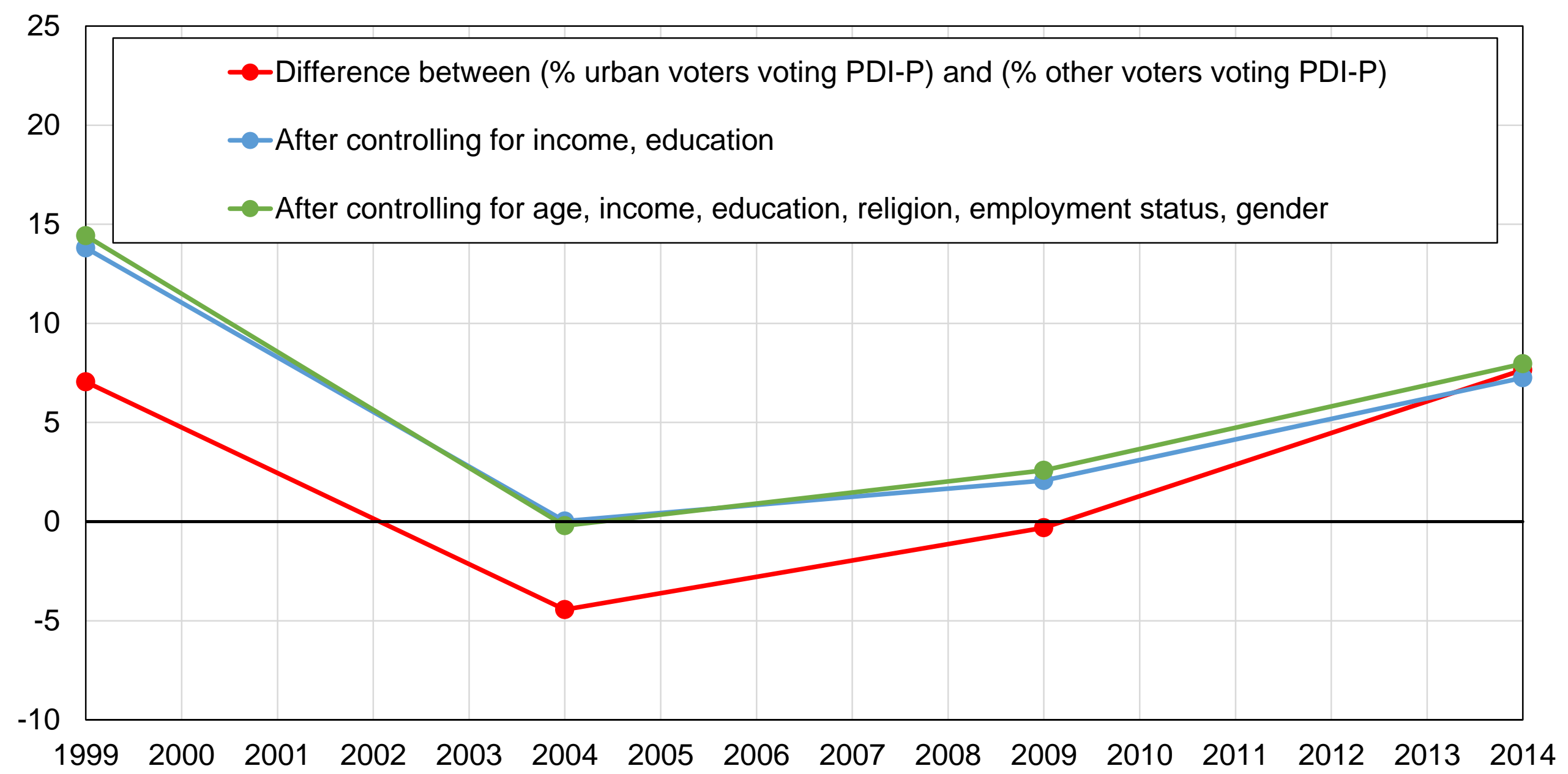

Source: authors' computations using Indonesian political attitudes surveys.

Note: the figure shows the difference between the share of urban voters voting for PDI-P and the share of other voters voting for PDI-P, before and after controls. 
Figure DI10 - Vote for PDI-P by ethnicity

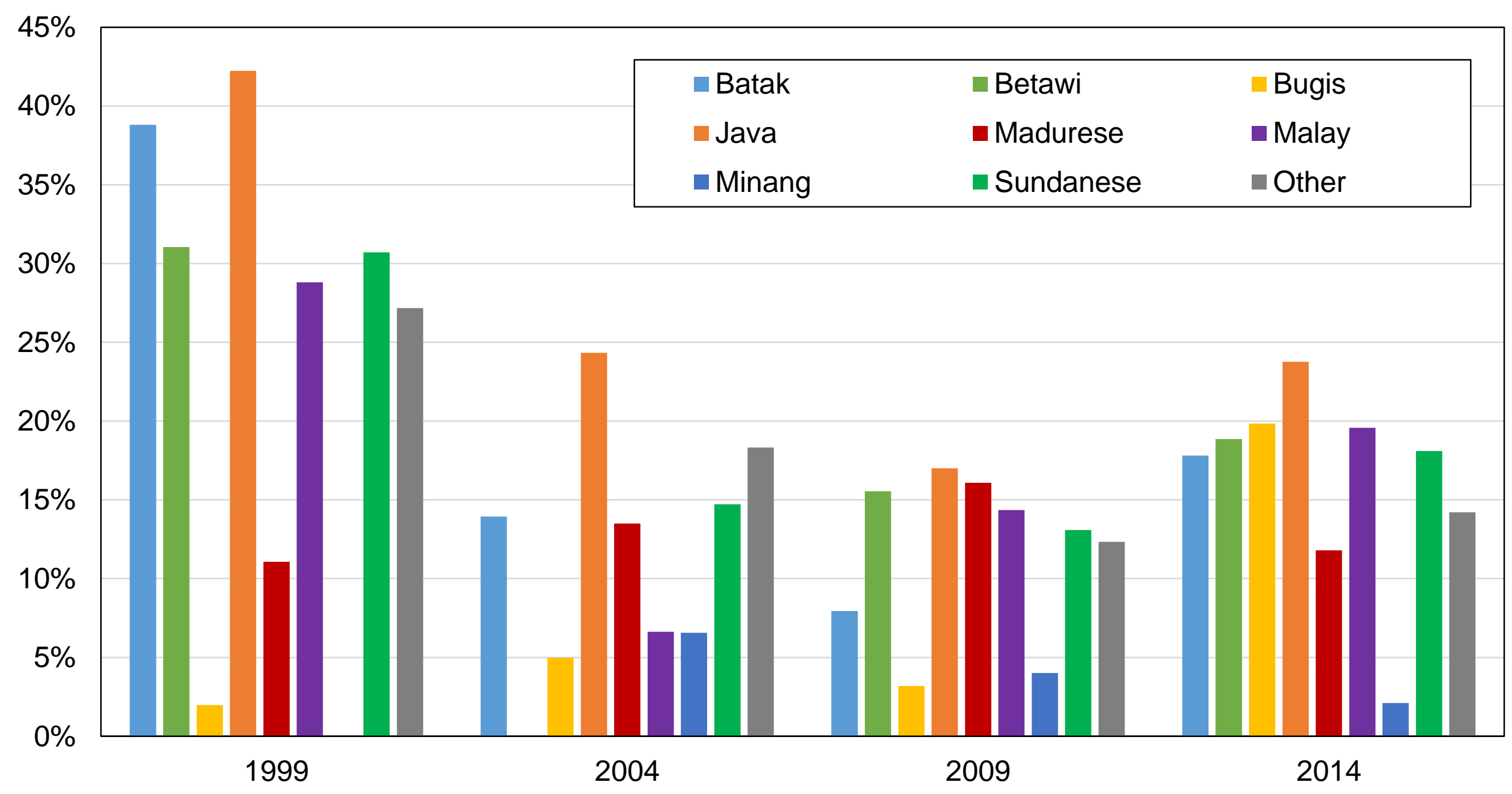

Source: authors' computations using Indonesian political attitudes surveys.

Note: the figure shows the share of votes received by PDI-P by ethnic affiliation. 


\section{Figure DI11 - Vote for PDI-P among Javanese voters}

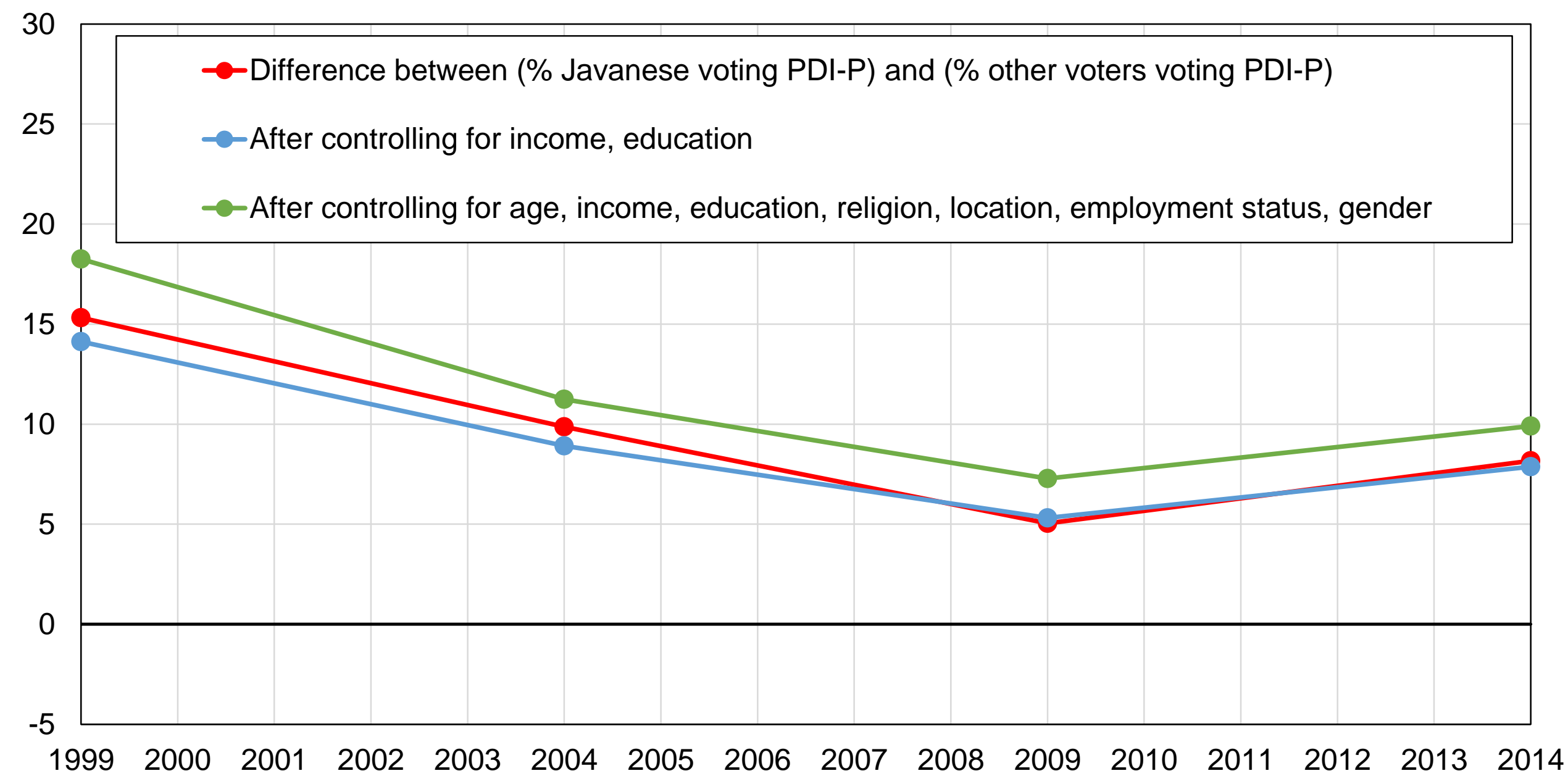

Source: authors' computations using Indonesian political attitudes surveys.

Note: the figure shows the difference between the share of Javanese voters voting for PDI-P and the share of other voters voting for PDI-P, before and after controls. 


\begin{tabular}{|cccc|}
\hline \multicolumn{5}{|c|}{} & \multicolumn{2}{c|}{ Table DA1 - Survey data sources } \\
\hline Year & Survey & Source & Sample size \\
\hline 1999 & CNEP, 1999 & Comparative National Elections Project & 2488 \\
2004 & CNEP, 2004 & Comparative National Elections Project & 1194 \\
2009 & CNEP, 2009 & Comparative National Elections Project & 1980 \\
2014 & CNEP, 2014 & Comparative National Elections Project & 1737 \\
\hline
\end{tabular}


Table DA2 - Complete descriptive statistics by year

\begin{tabular}{|c|c|c|c|c|}
\hline & 1999 & 2004 & 2009 & 2014 \\
\hline Gender: Man & $50 \%$ & $50 \%$ & $50 \%$ & $52 \%$ \\
\hline Ethnicity: Batak & $3 \%$ & $4 \%$ & $3 \%$ & $2 \%$ \\
\hline Ethnicity: Betawi & $3 \%$ & $1 \%$ & $1 \%$ & $3 \%$ \\
\hline Ethnicity: Bugis & $2 \%$ & $4 \%$ & $3 \%$ & $4 \%$ \\
\hline Ethnicity: Java & $45 \%$ & $42 \%$ & $41 \%$ & $41 \%$ \\
\hline Ethnicity: Madurese & $4 \%$ & $3 \%$ & $4 \%$ & $6 \%$ \\
\hline Ethnicity: Malay & $2 \%$ & $3 \%$ & $6 \%$ & $5 \%$ \\
\hline Ethnicity: Minang & $0 \%$ & $2 \%$ & $3 \%$ & $3 \%$ \\
\hline Ethnicity: Other & $25 \%$ & $24 \%$ & $23 \%$ & $22 \%$ \\
\hline Ethnicity: Sundanese & $17 \%$ & $17 \%$ & $14 \%$ & $15 \%$ \\
\hline Education: Elementary or lower & $30 \%$ & $18 \%$ & $24 \%$ & $16 \%$ \\
\hline Education: Primary & $23 \%$ & $26 \%$ & $26 \%$ & $29 \%$ \\
\hline Education: Lower secondary & $20 \%$ & $19 \%$ & $19 \%$ & $23 \%$ \\
\hline Education: Upper secondary & $20 \%$ & $27 \%$ & $23 \%$ & $24 \%$ \\
\hline Education: University or higher & $7 \%$ & $10 \%$ & $9 \%$ & $9 \%$ \\
\hline Age: $20-40$ & $76 \%$ & $62 \%$ & $51 \%$ & $48 \%$ \\
\hline Age: $40-60$ & $17 \%$ & $35 \%$ & $42 \%$ & $44 \%$ \\
\hline Age: $60_{+}$ & $7 \%$ & $3 \%$ & $7 \%$ & $8 \%$ \\
\hline Employment status: Employed & $64 \%$ & $66 \%$ & $28 \%$ & $62 \%$ \\
\hline Employment status: Inactive & $36 \%$ & $33 \%$ & $72 \%$ & $38 \%$ \\
\hline Location: Rural & $68 \%$ & $58 \%$ & $62 \%$ & $53 \%$ \\
\hline Religion:Islam & $88 \%$ & $87 \%$ & $88 \%$ & $91 \%$ \\
\hline Religion:Christian & $10 \%$ & $11 \%$ & $10 \%$ & $7 \%$ \\
\hline Religion:Others & $2 \%$ & $2 \%$ & $2 \%$ & $2 \%$ \\
\hline Collective prayer: Never & $2 \%$ & $6 \%$ & $14 \%$ & $13 \%$ \\
\hline Collective prayer: Sometimes & $15 \%$ & $36 \%$ & $35 \%$ & $38 \%$ \\
\hline Collective prayer: Often & $53 \%$ & $36 \%$ & $37 \%$ & $33 \%$ \\
\hline Collective prayer: Very often & $29 \%$ & $22 \%$ & $14 \%$ & $16 \%$ \\
\hline
\end{tabular}


Source: authors' computations using Indonesian political attitudes surveys.

Note: the table shows descriptive statistics by year for selected available variables. 


\begin{tabular}{|c|c|c|c|c|c|c|c|}
\hline \multicolumn{8}{|c|}{ Table DA3 - Full structure of the vote in the 2014 Indonesian election } \\
\hline \multirow[b]{2}{*}{ Overall vote share } & PDI-P & PD & Golkar & Nasdem & Hanura & Gerindra & Islamic Parties \\
\hline & $18,95 \%$ & $10,19 \%$ & $14,75 \%$ & $6,72 \%$ & $5,26 \%$ & $11,81 \%$ & $31,41 \%$ \\
\hline \multicolumn{8}{|l|}{ Education } \\
\hline Primary or lower & $17 \%$ & $9 \%$ & $18 \%$ & $8 \%$ & $5 \%$ & $11 \%$ & $31 \%$ \\
\hline Secondary & $21 \%$ & $11 \%$ & $12 \%$ & $7 \%$ & $5 \%$ & $12 \%$ & $32 \%$ \\
\hline Tertiary & $20 \%$ & $13 \%$ & $13 \%$ & $2 \%$ & $6 \%$ & $14 \%$ & $33 \%$ \\
\hline \multicolumn{8}{|l|}{ Income } \\
\hline Bottom $50 \%$ & $17 \%$ & $10 \%$ & $16 \%$ & $8 \%$ & $5 \%$ & $11 \%$ & $33 \%$ \\
\hline Middle 40\% & $21 \%$ & $10 \%$ & $14 \%$ & $6 \%$ & $6 \%$ & $11 \%$ & $30 \%$ \\
\hline Top 10\% & $23 \%$ & $12 \%$ & $12 \%$ & $3 \%$ & $5 \%$ & $15 \%$ & $30 \%$ \\
\hline \multicolumn{8}{|l|}{ Religion } \\
\hline Practicing Muslims & $16 \%$ & $9 \%$ & $15 \%$ & $7 \%$ & $5 \%$ & $12 \%$ & $35 \%$ \\
\hline Non-practicing Muslims & $19 \%$ & $10 \%$ & $14 \%$ & $6 \%$ & $7 \%$ & $11 \%$ & $32 \%$ \\
\hline Non-Muslims & $38 \%$ & $13 \%$ & $17 \%$ & $13 \%$ & $1 \%$ & $10 \%$ & $8 \%$ \\
\hline \multicolumn{8}{|l|}{ Location } \\
\hline Urban & $23 \%$ & $7 \%$ & $13 \%$ & $5 \%$ & $5 \%$ & $13 \%$ & $34 \%$ \\
\hline Rural & $15 \%$ & $13 \%$ & $17 \%$ & $9 \%$ & $6 \%$ & $11 \%$ & $29 \%$ \\
\hline \multicolumn{8}{|l|}{ Gender } \\
\hline Woman & $20 \%$ & $10 \%$ & $16 \%$ & $6 \%$ & $6 \%$ & $9 \%$ & $32 \%$ \\
\hline Man & $18 \%$ & $10 \%$ & $13 \%$ & $8 \%$ & $5 \%$ & $15 \%$ & $31 \%$ \\
\hline \multicolumn{8}{|l|}{ Age } \\
\hline $20-39$ & $20 \%$ & $12 \%$ & $14 \%$ & $6 \%$ & $6 \%$ & $12 \%$ & $29 \%$ \\
\hline $40-59$ & $18 \%$ & $8 \%$ & $15 \%$ & $7 \%$ & $4 \%$ & $12 \%$ & $34 \%$ \\
\hline $60+$ & $18 \%$ & $10 \%$ & $19 \%$ & $9 \%$ & $5 \%$ & $9 \%$ & $31 \%$ \\
\hline \multicolumn{8}{|l|}{ Ethnic group } \\
\hline Madurese & $12 \%$ & $2 \%$ & $4 \%$ & $7 \%$ & $9 \%$ & $18 \%$ & $48 \%$ \\
\hline Bugis & $20 \%$ & $14 \%$ & $11 \%$ & $5 \%$ & $0 \%$ & $24 \%$ & $26 \%$ \\
\hline Minang & $2 \%$ & $14 \%$ & $21 \%$ & $4 \%$ & $0 \%$ & $26 \%$ & $33 \%$ \\
\hline Sundanese & $18 \%$ & $10 \%$ & $17 \%$ & $4 \%$ & $5 \%$ & $9 \%$ & $36 \%$ \\
\hline Betawi & $19 \%$ & $7 \%$ & $8 \%$ & $7 \%$ & $3 \%$ & $11 \%$ & $45 \%$ \\
\hline Java & $24 \%$ & $8 \%$ & $12 \%$ & $7 \%$ & $5 \%$ & $10 \%$ & $33 \%$ \\
\hline
\end{tabular}




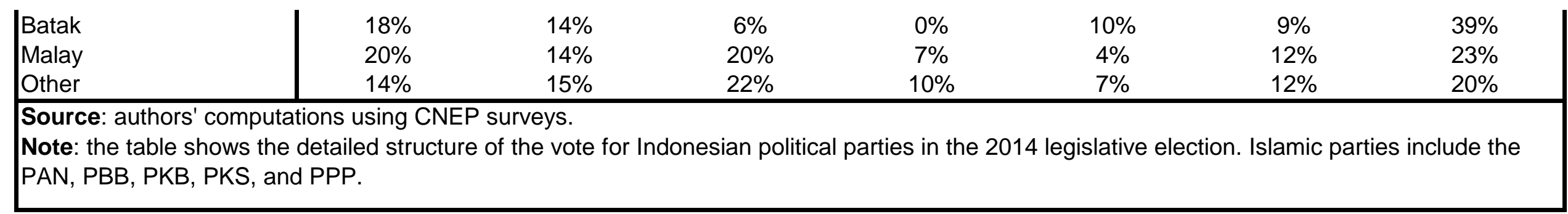

